UNIVERSIDADE DE SÃO PAULO
FACULDADE DE FILOSOFIA, LETRAS E CIÊNCIAS HUMANAS

SELMA MARTINS MEIRELES

\title{
A DISSENSÃO E AS ESTRATÉGIAS DE TRABALHO DA FACE EM DIÁLOGOS DO ALEMÃO
}

Tese apresentada ao Departamento de Letras Modernas da Faculdade de Filosofia, Letras e Ciências Humanas da Universidade de São Paulo, para obtenção do grau de Doutor em Letras (Área de Concentração: Língua e Literatura Alemã).

Orientadora:

Profa. Dra. Masa Nomura

São Paulo

1997 
"A palavra de que mais gosto é 'não'. Chega sempre um momento na nossa vida em que é necessário dizer não. $\mathrm{O}$ 'não' é a única coisa efetivamente transformadora, que nega $o$ status quo."

José Saramago (em entrevista à Folha de São Paulo, 27/10/91)

"Ich bin der Geist, der stets verneint."

J.W. Goethe - Faust

"Ele disse 'não' ".

Os Inocentes (grupo de rock paulista) 
À minha família, pelo eterno apoio, e a todos aqueles que, de um modo ou de outro, me levam a crescer. 
Agradecimentos

A realização deste trabalho só foi possível graças à colaboração direta ou indireta de muitas pessoas. Manifestamos nossa gratidão a todas elas e de forma especial:

a Masa, pela infinita paciência;

ao Hardarik, pelas incontáveis discussões;

aos colegas da Área de Alemão da FFLCH/USP, pelo incentivo e compreensão na distribuição das aulas;

ao Serviço Alemão de Intercâmbio Acadêmico (DAAD), pela bolsa de estudos que me permitiu obter a bibliografia necessária a este trabalho;

aos membros do Institut für Deutsche Sprache em Mannheim, RFA, pela disponibilidade e colaboração;

a Kátia Cristina Pinto, analista de sistemas do Centro de Informática da FFLCH/USP, pelo auxílio na configuração dos gráficos. 


\section{RESUMO}

Neste estudo, analisamos ocorrências de Dissensão em discussões entre falantes alemães com referência à sua expressão lingüística e aos procedimentos utilizados para manter o bom andamento de uma interação, os quais denominamos Trabalho da Face. Um elenco de Estratégias de Trabalho da Face foi definido com base nas quatro super-estratégias propostas por BROWN \& LEVINSON, a saber: expressão direta sem compensação, compensação baseada na polidez positiva, compensação baseada na polidez negativa e expressão off record. A Dissensão foi definida como uma atitude proposicional de desacordo por parte do falante, referente a conteúdos ou atitudes imputados por ele ao seu interlocutor. A partir de seu escopo, definimos quatro categorias de Dissensão, sendo que tais categorias provaram-se influentes quanto à seleção das Estratégias de Trabalho da Face utilizadas para sua expressão. Em geral, a superestratégia menos utilizada é a expressão direta sem compensação, seguida do uso de estratégias off record, observando-se ainda um notável equilíbrio no uso de estratégias de Compensação Positiva e Negativa. Quanto à expressão lingüística da Dissensão, concluiu-se que não há meios lingüísticos exclusivos para esse fim, porém, a grande maioria das ocorrências no corpus apresenta elementos lexicais semanticamente negativos. 


\section{ABSTRACT}

This study analyses tokens of Dissension in samples of discussions among German speakers regarding its linguistic expression and the procedures used to maintain the due course of an interaction, which GOFFMAN denominated face-work. A set of face-work strategies was defined based upon the four super strategies of face-work proposed by BROWN \& LEVINSON: on record, positive redress, negative redress and off record. Dissension was defined as a propositional attitude of a speaker referring to topics or attitudes imputed by him to his partner in conversation. According to its scope, Dissension was classified in four categories, which proved themselves influent upon the choice of the facework strategies used to express them. In general, the least represented strategy is the Dissension bold on record, followed by strategies off record. A remarkable balance between positive and negative redress must be noted as well. As to the linguistic expression of Dissension, it has been concluded that there are no specific linguistic means to that, although the great majority of the occurrences in the corpus displays semantically negative lexical elements. 


\section{ZUSAMMENFASSUNG}

In dieser Arbeit werden Dissens-Okkurrenzen aus Diskussionen unter deutschen Sprechern in bezug sowohl auf ihren linguistischen Ausdruck als auch auf die Verfahren untersucht, die dabei den guten Verlauf der Interaktion sichern sollen und als Face-work bezeichnet werden. Eine Liste von Face-Work-Strategien wurde aufgrund der vier Super-Strategien von BROWN \& LEVINSON (on record, positive redress, negative redress und off record) aufgestellt. Dissens wird als eine Sprechereinstellung der Nicht-Übereinstimmung bezüglich einer dem Gesprächspartner zugeschriebenen Sachverhaltsdarstellung oder Attitüde definiert. Anhand ihres Gegenstandes wurde Dissens in vier Kategorien eingeteilt, die die Auswahl der für ihren Ausdruck gebrauchten Face-WorkStrategien beeinflussen. Im allgemeinen wird der bold on record-Ausdruck am wenigsten gebraucht, gefolgt von off record-Strategien. Es sei dazu noch auf das bemerkenswerte Gleichgewicht im Gebrauch der Strategien für positive und negative redress hingewiesen. Was den linguistischen Ausdruck der Dissens betrifft, wurde festgestellt, daß es keine ausschließlich für diesen Zweck geeigneten linguistischen Mittel gibt; jedoch weist die große Mehrheit der Okkurrenzen im Korpus semantisch negative lexikalische Elemente auf. 


\section{SUMÁRIO}

\section{INTRODUC̃̃̃O}

Interesse do Tema

Objetivos do Trabalho

CAPÍTUlo I - Fundamentos TeóRICOS

1.1 A Dissensão 6

1.1.1 Estudos sobre a Dissensão 6

1.1.1.1 SORNIG 6

1.1.1.2 APELTAUER 10

$\begin{array}{lll}\text { 1.1.1.3 SPRANZ-FOGASY } & 12\end{array}$

1.1.1.4 KOHNEN 18

1.1.2 O Conceito de Dissensão 21

1.2 O Conceito de Face 25

1.2.1 GrICE e as Máximas da Conversação 25

1.2.2 SPERBER \& WILSON: O Princípio de Relevância 26

1.2.3 Robin LakofF: As Máximas da Polidez 29

1.2.4 Erving Goffman e o Conceito de Face 33

1.3 O Trabalho da Face 35

1.3.1 Brown \& Levinson: as Estratégias de Polidez 35

1.3.2 Leech: o Princípio de Polidez 38

1.3.3 Os conceitos de Trabalho da Face e de Polidez 40

1.3.4 A seleção das Estratégias de Trabalho da Face pelo falante 41

1.3.5 Realizações das Estratégias de Trabalho

1.3.5.1 Fazer o FTA diretamente 47

1.3.5.2 Estratégias de Compensação baseadas

1.3.5.3 Estratégias de Compensação baseadas

1.3.5.4 Fazer o FTA off record

$1.4 \quad$ A Dissensão e o Trabalho da Face $\quad 60$

1.4.1 A Dissensão como ameaça potencial à Face $\quad 60$

1.4.2 A Dissensão e as Estratégias de Trabalho da Face 61 
CAPÍTUlo II - MATERIAl e MÉTOdo

$2.1 \quad$ Corpus 63

2.1.1 Definição do corpus da pesquisa $\quad 64$

2.1.1.1 O gênero "Discussão"

2.1.1.2 A Dissensão em Discussões $\quad 68$

2.1.2 Descrição do corpus da pesquisa 70

2.1.3 Caracterização dos inquéritos 72

$\begin{array}{lll}2.2 & \text { Procedimentos } & \mathbf{7 6}\end{array}$

2.2.1 Levantamento das ocorrências 76

2.2.2 Classificação das ocorrências 79

2.2.2.1 Dissensão referente à Expressão Lingüística

2.2.2.2 Dissensão referente a Parte de uma Proposição 81

2.2.2.3 Dissensão referente à Totalidade de uma Proposição 81

2.2.2.4 Dissensão referente ao Rumo da Interação 8

2.2.3 As Estratégias de Trabalho da Face 83

2.2.4 A realização lingüística das Estratégias

de Trabalho da Face na Dissensão 83

CAPÍTULO III - ANÁLISE DAS OCORRÊNCIAS E DisCUSSÃo dOS

RESULTADOS

3.1 Freqüência de ocorrência das categorias de Dissensão 84

3.2 A Dissensão e as Estratégias de Trabalho da Face 87

3.2.1 Dissensão off record 94

3.2.1.1 Dê pistas para associações 96

$\begin{array}{lll}\text { 3.2.1.2 } & \text { Seja irônico } & 97\end{array}$

$\begin{array}{lll}3.2 .1 .3 & \text { Seja vago } & 98\end{array}$

$\begin{array}{lll}\text { 3.2.1.4 Exagere } & 98\end{array}$

3.2.1.5 A realização lingüística das Estratégias off record na Dissensão $\quad 99$

$\begin{array}{lll}\text { 3.2.2 A Dissensão direta } & 101\end{array}$

3.2.2.1 A realização lingüística da Dissensão direta 103

3.2.2.2 Quadro sinótico da realização lingüística da Dissensão direta 115

3.2.2.3 Dissensão direta, sem compensação 116

$\begin{array}{lll}\text { 3.2.2.4 Dissensão direta com Estratégias } & \\ \text { de Compensação Positiva } & 117\end{array}$

$\begin{array}{lll}\text { 3.2.2.4.1 Evite discordância } & 119\end{array}$ 
3.2.2.4.1.1 Concorde simbolicamente 119

3.2.2.4.1.2 Relativize a opinião do interlocutor 123

3.2.2.4.2 Busque concordância: relativize a própria opinião 127

3.2.2.4.3 Crie/pressuponha pontos em comum 129

3.2.2.4.4 Intensifique o interesse: aproxime o interlocutor 135

$\begin{array}{lll}3.2 .2 .4 .5 & \text { Graceje } & 138\end{array}$

3.2.2.4.6 Use identificadores grupais 138

3.2.2.4.7 Dê (ou peça) razões 139

3.2.2.4.8 Inclua falante e interlocutor na atividade: gerencie a dêixis pessoal 141

$\begin{array}{lll}\text { 3.2.2.4.9 Seja otimista } & 143\end{array}$

3.2.2.4.10 Quadro sinótico da realização lingüística de Estratégias de Compensação Positiva na Dissensão

3.2.2.5 Dissensão direta com Estratégias de Compensação Negativa 146

3.2.2.5.1 Utilize formas convencionalizadas 147

$\begin{array}{lll}3.2 .2 .5 .2 & \text { Relativize a própria opinião } & 152\end{array}$

$\begin{array}{ll}\text { 3.2.2.5.3 Evite afirmações: faça perguntas } & 158\end{array}$

3.2.2.5.4 Gerencie o grau de realidade 159

$\begin{array}{ll}\text { 3.2.2.5.5 Minimize a imposição } & 161\end{array}$

3.2.2.5.6 Dê deferência 163

3.2.2.5.7 Afastamento pessoal 166

3.2.2.5.7.1 Impersonalize: gerencie a dêixis pessoal 166

$\begin{array}{ll}\text { 3.2.2.5.7.2 Apele à autoridade/objetividade } & 170\end{array}$

$\begin{array}{lll}3.2 .2 .5 .7 .3 & \text { Invoque regras gerais } & 170\end{array}$

$\begin{array}{lll}\text { 3.2.2.5.7.4 Defocalize os participantes } & 173\end{array}$

3.2.2.5.8 Afastamento epistêmico: utilize verbos modais 176

$\begin{array}{lll}\text { 3.2.2.5.9 Afastamento temporal: gerencie } & \\ & \text { a dêixis temporal } & 177\end{array}$

$\begin{array}{lll}\text { 3.2.2.5.10 Indique relutância } & 178\end{array}$

$\begin{array}{lll}\text { 3.2.2.5.11 Peça desculpas } & 181\end{array}$

3.2.2.5.12 Quadro sinótico da realização lingüística de Estratégias de Compensação Negativa na Dissensão $\quad 182$

3.2.2.6 Estratégias off record em Dissensões diretas 183

$\begin{array}{lll}\text { 3.2.2.6.1 Dê pistas para associações } & 183\end{array}$

$\begin{array}{lll}\text { 3.2.2.6.2 Use perguntas retóricas } & 184\end{array}$

$\begin{array}{lll}\text { 3.2.2.6.3 } & \text { Seja irônico } & 184\end{array}$

$\begin{array}{lll}\text { 3.2.2.6.4 Seja incompleto } & 185\end{array}$

$\begin{array}{lll}3.2 .2 .6 .5 & \text { Exagere } & 185\end{array}$

3.2.2.6.6 Use metáforas $\quad 185$

$\begin{array}{lll}3.2 .2 .6 .7 & \text { Seja vago } & 186\end{array}$ 
3.2.2.6.8 A realização lingüística de Estratégias off record em Dissensões diretas

\section{CAPÍTULO IV - INTERPRETAÇ̃̃o dOS RESULTADOS}

4.1 O uso das Estratégias de Trabalho da Face na expressão da Dissensão

4.2 As Estratégias de Compensação na expressão da Dissensão

4.2.1 As Estratégias de Compensação Positiva 190

4.2.2 As Estratégias de Compensação Negativa 191

4.3 Categorias de Dissensão e as Estratégias de Trabalho daFace 193

4.3.1 A Dissensão referente à Expressão Lingüística 193

4.3.2 A Dissensão referente a Parte de uma Proposição 196

4.3.3 A Dissensão referente à Totalidade da Proposição 199

4.3.4 A Dissensão referente ao Rumo da Interação 201

$\begin{array}{ll}\text { CAPÍtulo V - CONSIDERaÇÕes FinaIS } & 204\end{array}$

Referências Bibliográficas $\quad 210$

$\begin{array}{ll}\text { Anexo: Corpus da Pesquisa } & 215\end{array}$ 


\section{LISTA DE FIGURAS}

"Atos de fala não-concordantes"

("Nichtakkordierende Sprechhandlungen - NASH")

Estratégias para execução do FTA

Estratégias de polidez positiva

52

Estratégias de polidez negativa

Freqüência de ocorrência das categorias de Dissensão

Freqüência de ocorrência de Super-Estratégias

de Trabalho da Face no corpus da pesquisa

Freqüência de Ocorrência das Estratégias formais de Trabalho da Face no corpus da pesquisa

Ocorrência das Super-estratégias de Trabalho da Face em Dissensões referentes à Expressão Lingüística

Frequiência de Ocorrência de Estratégias formais em Dissensões referentes à Expressão Lingüística

Ocorrência das Super-estratégias de Trabalho da face no Uso Estratégico de Dissensões referentes à Expressão Lingüística

Freqüência de Ocorrência de Estratégias formais no Uso Estratégico de Dissensões referentes

à Expressão Lingüística

Ocorrência das Super-estratégias de Trabalho da Face em Dissensões referentes a Parte de uma Proposição

Freqüência de Ocorrência de Estratégias formais em Dissensões referentes a Parte de uma Proposição 
Ocorrência das Super-estratégias de Trabalho da Face em Dissensões referentes à Totalidade de uma Proposição

Freqüência de Ocorrência de Estratégias formais em Dissensões referentes à Totalidade de uma Proposição

Ocorrência das Super-estratégias de Trabalho da Face em Dissensões referentes ao Rumo da Interação

Freqüência de Ocorrência de Estratégias formais em Dissensões referentes ao Rumo da Interação 


\section{INTRODUCẼ̃O}

\section{Interesse do Tema}

O jornal Folha de São Paulo de 25 de fevereiro de 1996 traz um artigo de Michael Kepp, correspondente do Brasil no jornal The Observer de Londres, intitulado "Modos brasileiros de escapar do 'não' ". No artigo, o autor discorre sobre o talento dos brasileiros em "navegar em torno dos negativos" por meio de "expressões propositadamente vagas como 'pode ser', 'vamos ver', 'se der', da qual (sic) os brasileiros diariamente se apropriam para desviar da palavra 'não'". Kepp, que explica ter sido "criado não no Brasil católico, mas na América protestante, onde a salvação está ligada à conduta pessoal e moral rígida no cotidiano, e não na redenção", especula que "isso ajuda a explicar porque os americanos são muito mais bruscos que os brasileiros, que são mais corteses. É por isso que os brasileiros nos chamam de 'objetivos', para não dizerem que somos grosseiros."

Tais considerações sobre diferenças culturais a respeito de 'cortesia' ou 'grosseria', no que se refere aos modos de expressão, não constituem novidade para estudiosos ou para leigos, pois o contato entre culturas diferentes sempre leva a uma comparação, a qual inevitavelmente é centrada nos valores próprios de cada cultura, gerando juízos como: "tal povo é gentil/grosseiro/ trabalhador/preguiçoso, etc." Tal comparação é a raiz dos preconceitos e, embora seja condenada com horror pelos politicamente corretos de todo o mundo, nada pode ser feito para refreá-la, pois, a partir do momento em que o indivíduo toma consciência de seu ego como distinto daquele do outro, a comparação centrada no modelo próprio e o juízo de valores são inevitáveis. Além do mais, não se pode negar que, se tais contrastes são sentidos por vários membros de uma mesma cultura, eles realmente existem e não podem ser simplesmente descartados como invenções de indivíduos preconceituosos.

$\mathrm{O}$ artigo do jornalista americano é um excelente exemplo de que a a maneira como as pessoas se expressam lingüisticamente, com muita freqüência, é considerada como expressão de seu caráter. O autor do artigo detecta um ponto de divergência lingüístico entre sua cultura e a brasileira, quando afirma que falantes brasileiros evitam utilizar-se de elementos negativos nas interações. $O$ jornalista especula que a origem dessa aparente 
"objetividade maior" dos americanos frente aos brasileiros talvez esteja na grande influência do protestantismo na formação dos primeiros, a qual influenciaria seu modo de expressão.

Porém, mesmo dentre comunidades da mesma orientação religiosa, ocorrem choques quanto à questão da polidez. O choque cultural vivenciado pelo jornalista, entre "brasileiros corteses/americanos rudes" repete-se quando alemães interagem com americanos, porém, com a diferença que a dicotomia formada consiste de "americanos corteses/alemães rudes", conforme demonstram vários estudos (cf. HOUSE, 1979; House/KASPER, 1981; BYRNeS, 1986 e KotthofF, 1989 e 1989(a), entre outros), ainda que ambas as culturas sejam predominantemente protestantes. Alemães assumem também o pólo "rude" frente a outras culturas (cf., por exemplo, GENZMER, 1987 e GÜNTHNER, 1993), sendo que isto normalmente é creditado ao fato de os alemães serem considerados por demais diretos e incisivos.

Tal "franqueza total" parece ser admitida e cultivada pelos próprios alemães, que freqüentemente citam as palavras de Goethe: im Deutschen lügt man, wenn man höflich ist ("em alemão, mente-se quando se é gentil" Faust, Ato 2). No entanto, isto não significa que os alemães não conheçam a polidez ou, em nossos termos, não se utilizem de Estratégias de Trabalho de Face. Vários estudos mostram o contrário, inclusive o de WeINRICH (1986), que contextualiza e desmistifica a citação de Goethe. A sensação de desconforto surge do uso de diferentes Estratégias de Trabalho da Face em contextos diversos, em cada cultura.

É interessante que o jornalista americano tenha escolhido exatamente a aparente dificuldade de falantes brasileiros utilizarem-se de expressões negativas como ponto de partida para suas reflexões sobre a dificuldade de assumir compromissos e posições, pois exatamente essa "queixa" é freqüentemente expressa por falantes alemães com relação a brasileiros, dando origem ao mesmo tipo de valoração sobre "brasileiros corteses/ dissimulados" frente a "alemães diretos/grosseiros".

A constatação de tal conflito levou-nos a abordar um de seus aspectos em nossa dissertação de mestrado, na qual analisamos o uso de elementos sintáticos negativos em diálogos das duas línguas. Este trabalho levou-nos a concluir que falantes alemães e brasileiros utilizam-se de elementos sintáticos negativos com a mesma freqüência de ocorrência, mas não nas mesmas situações de comunicação: 
A análise dos dados obtidos mostrou que a primeira grande divergência no uso da NEGAÇÃo em ambas as línguas é na realidade semântico-pragmática, sendo que falantes brasileiros parecem sub-utilizar elementos sintáticos negativos em categorias semânticas de negação que implicam contestação da ilocução ou do valor de verdade de conteúdos apresentados pelo interlocutor. (MEIRELES, 1991:141)

Através das pesquisas para nossa dissertação de mestrado, desenvolvemos um grande interesse pela diferença de freqüência de uso de elementos sintáticos negativos nas categorias que implicam discordância, ou Dissensão, com o interlocutor em ambas as línguas. Se não há razões porque brasileiros devam expressar menos sua Dissensão que os alemães, haveria a possibilidade de uma preferência dos brasileiros por uma Dissensão menos explícita, devida a diferentes regras culturais e visando a minimizar a possibilidade de conflitos, como sugerido no artigo anteriormente citado?

Uma resposta definitiva a essas indagações, por sua complexidade e abrangência, certamente foge ao escopo de uma tese de doutorado. $\mathrm{O}$ primeiro passo nessa direção consiste no estudo da expressão lingüística da Dissensão entre falantes de uma mesma comunidade e das Estratégias de Trabalho da Face ${ }^{1}$ mais utilizadas em cada cultura, que servirá de base para posteriores estudos e especulações. Nossa tese de doutorado centrar-se-á, portanto, no estudo da expressão da Dissensão em diálogos falados do Alemão.

Assim sendo, constitui objeto deste trabalho o estudo das expressões lingüísticas da Dissensão em diálogos entre falantes nativos do alemão, com relação ao Trabalho de Face desenvolvido pelos interlocutores.

\footnotetext{
${ }^{1}$ As Estratégias de Trabalho da Face serão definidas e detalhadas no item 1.3.
} 


\section{Objetivos do Trabalho}

Partindo das reflexões desenvolvidas anteriormente, nosso trabalho tem por objetivos:

1. Realizar um levantamento de formas lingüísticas utilizadas na expressão de Dissensão com o interlocutor em diálogos entre falantes nativos do alemão.

2. Definir as Estratégias de Trabalho da Face utilizadas pelos falantes em tais situações.

3. Propor uma sistematização das Estratégias de Trabalho de Face em relação à Dissensão.

Os fundamentos teóricos utilizados para atingir estes objetivos são detalhados no próximo capítulo. Para a definição dos conceitos básicos de "Dissensão" e "Estratégias de Trabalho da Face", examinamos vários estudos sobre o assunto ${ }^{2}$. Os trabalhos mais pertinentes à nossa abordagem estão resenhados nos itens do Capítulo I, seguidos de uma análise e comparação das diversas abordagens, explicitando o caminho que nos levou à elaboração das definições utilizadas como base para esta pesquisa. Ainda neste capítulo, apresentamos o elenco de Estratégias de Trabalho da Face consideradas neste estudo.

O Capítulo II apresenta os procedimentos para a constituição do corpus da pesquisa, juntamente com uma breve descrição do mesmo. Apresenta também a sugestão de uma categorização da Dissensão, tendo por base seu escopo.

\footnotetext{
2 RosA (1992: 20) utiliza o termo "estratégias de polidez", como tradução do termo inglês politeness strategies. A mesma autora utiliza ainda o termo "processo de figuração" para o termo inglês face work de GofFMANN. Consideramos que estes dois termos em português não exprimem suficientemente a dimensão ativa do falante que se utiliza de determinadas estratégias para preservar a sua posição frente aos demais membros da interação, por isso, preferimos utilizar neste trabalho o termo "Estratégias de Trabalho da Face". O termo alemão Imagearbeit (HoLly, 1979) aproxima-se mais da dimensão ativa que pretendemos ressaltar neste estudo, mas o termo Face nos parece preferível a Image, pois este último evoca conotações de distanciamento e artificialidade que julgamos não estarem sempre presentes.
} 
As ocorrências de Dissensão no corpus, bem como os resultados da análise da freqüência de uso e da expressão lingüística das diversas Estratégias de Trabalho de Face utilizadas para sua realização, são apresentados e discutidos nos itens do Capítulo III.

O Capítulo IV apresenta uma interpretação dos resultados obtidos e a proposta de uma sistematização do uso das Estratégias de Trabalho da Face em relação às categorias de Dissensão, os quais são apresentados de forma concisa no $\underline{\text { Capítulo V }}$, juntamente com nossas considerações finais sobre o tema.

Todas as traduções de textos de autores estrangeiros são de nossa autoria, sendo que os textos originais das citações de autores alemães constam em notas de rodapé. 


\section{CAPÍTULO I - FUNDAMENTOS TEÓRICOS}

\subsection{A Dissensão}

A Dissensão, assim como a entendemos no presente trabalho, tem sido objeto de vários estudos, embora nem sempre sob essa denominação. SORNIG, em um estudo de 1977, apresenta a diversidade de termos que podem ser utilizados em diversas línguas para expressar esse conceito:

The various specific facets of the German 'widersprechen' are made explicit in English by lexical items such as 'gainsay', 'contradict', 'object' and 'disagree'. We use these terms here indiscriminately, as we assume that the meaning of the German verb coincides with the central meaning of the English expressions. [...] The essential characteristic of any expression of disagreement is that it is a reflection, perhaps only implicitly so, of a preceding (speech) act which must have been decoded first and, above all, must have been doubted in some of its details [...] (SORNIG, 1977: 361)

\subsubsection{Estudos sobre a Dissensão}

Em vista do exposto acima, há vários trabalhos em inglês e alemão (cf. BlaKemore 1989; Hindelang, 1980; Keim/Schwitalla 1989; KotTHOFF 1989 e 1993; PoMERANZ, 1984; SCHWITALla 1977a, 1977b, entre outros), que se ocupam de aspectos da Dissensão, sob denominações como: disagreement (desacordo), Dissens (Dissensão), denial (negação), contradiction, Widerspruch (contradição), Zurückweisung (rejeição), 'nichtakkordierende Sprechhandlungen' ("atos de fala não-concordantes") etc. Resenhamos, a seguir, os trabalhos que nos forneceram o material mais significativo para definir o conceito de Dissensão que utilizaremos em nossa tese.

\subsubsection{SorNig, Karl: "Disagreements and Contradictions as Communicative Acts" (Desacordos e contradições como atos comunicativos)}

Neste artigo, SoRNIG tem primeiramente interesses didáticos, pleiteando maior atenção dos professores e a inclusão, em sala de aula, do treino das habilidades de responder, perguntar, concordar e discordar como necessárias ao pleno desenvolvimento da personalidade dos alunos e de sua 
competência lingüística. Para tanto, SORNIG tenta estabelecer algumas de suas características como eventos comunicativos. No item 5 de seu artigo, o autor enfoca a descrição do ato comunicativo 'desacordo'. No item 6, é discutido o papel do 'desacordo' na sala de aula, e no item 7, são apresentadas algumas considerações sobre o silêncio como ato comunicativo de desacordo. Resenharemos aqui apenas os itens 5 e 7, pois nossa pesquisa não tem interesses didáticos imediatos.

Conforme citado acima, SORNIG considera como característica essencial de qualquer expressão de desacordo a sua relação, mesmo que apenas implicitamente, com um ato (de fala) precedente, o qual é posto em dúvida em alguns de seus detalhes (cf. SORNIG, 1977: 361). Para SORNIG, é muito importante o fato de que a pessoa que expressa dúvida ou desacordo precisa ter entendido o que o interlocutor quis realmente transmitir com seu enunciado; ou seja, o desacordo geralmente se refere não ao que foi efetivamente dito (said) em um certo enunciado, mas sim, à intenção comunicativa do falante (what was meant). Fundamental para o desacordo é a sua recorrência ao pré-texto, ou seja, às contribuições lingüísticas à comunicação que precedem o momento do desacordo. Porém, cabe ao falante decidir em que grau o pré-texto será utilizado (ou não) na formulação da expressão do desacordo. Quanto ao conteúdo, o falante pode escolher quais dos detalhes cognitivos do pré-texto ele quer corrigir ou sobre os quais quer expressar suas dúvidas. Assim, o ato de desacordo permite um alto grau de liberdade no que se refere ao objeto de desacordo, enquanto, por outro lado, sua verbalização é facilitada por uma préformulação por parte do proponente (cf. SoRNIG, 1977: 362). Portanto, dificuldades em expressar desacordo são menos metalingüísticas que metacomunicativas: sua expressão é dificultada pelas relações sociais entre as pessoas envolvidas. Em situação de sala de aula, por exemplo, fazer perguntas e pedir mais informações pode ser interpretado como forma de protesto. Baseado nisso, SORNIG conclui:

Tentatively speaking, any utterance that comments upon a pre-text by questioning part of its semantic or pragmatic information (sometimes its formal structure as well), correcting or negating it (semantically or formally) will be called an act of disagreement or contradiction. (SORNIG, 1977: $36^{3}$

\footnotetext{
${ }^{33}$ Em uma formulação inicial, qualquer enunciado que comente sobre um pré-texto, questionando parte de sua informação semântica ou pragmática (e às vezes também sua estrutura formal), corrigindo-a ou negando-a (semântica ou formalmente), será denominado um ato de desacordo. (SORNIG, 1977: 363)
} 
Ressaltando que não pretende fazer uma análise completa do ato de fala 'desacordo', o autor apresenta à página 363 uma lista de seus critérios descritivos e condições de realização, que podem ser resumidos da seguinte maneira:

a) S1 (falante 1) diz algo e quer dizer exatamente isso (ato de fala 1);

b) S2 (falante 2) entende o que S1 quis dizer, sem precisar de informação adicional;

c) S2 oferece uma asserção que ele considera verdadeira e que difere da de S1, excluindo a possibilidade de acordo;

d) S2 quer informar S1 sobre essa diferença, dispõe de elementos de um sistema comunicativo compreensível para S1 e verbaliza seu desacordo (ato de fala 2);

e) S2 tem o turno para responder.

Segundo o autor, S2, ao responder, fecha o círculo que faz de 'propor e discordar' uma seqüência de três passos.

À página 364, SORNIG lista as condições de felicidade do ato de fala de 'desacordo', que aqui apresentamos resumidamente:

a) S1 está em contato comunicativo com S2 (condição preparatória);

b) S2 utiliza um código não só reconhecível por S1, mas também apropriado à situação.

c) O desacordo de S2 é baseado (formalmente) na intervenção de S1. S2 também pode formular o desacordo de modo formalmente diferente no que concerne à estrutura de superfície, mas deve usar (condição essencial) o background pressuposicional da intervenção de S1 (A1), de um modo inteligível para S1;

d) $\mathrm{S} 1$ é capaz de reconhecer a correção do A1 (condição preparatória);

e) S2 quer realizar a correção (A2);

f) S1 entende que o turno é seu e reage a A2, o que pode ser feito reconhecendo a validade ou levantando objeções a A2.

SORNIG levanta também alguns aspectos, que "poderiam/deveriam ter conseqüências didáticas" (cf. SoRNIG, 1977: 364), dos quais listamos aqui os que têm maior interesse para nossa pesquisa:

a) Como desacordos são modelados de acordo com um pré-texto, possivelmente uma tipologia de atos de desacordo poderia basear-se na estrutura formal de seus pré-textos.

b) O desacordo não é sensível apenas ao seu co-texto, mas também ao seu contexto (situacional). 
c) A seqüência dizer-rejeitar (saying-gainsaying) compreende diversas operações, como: decodificar uma estrutura superficial, adivinhando sua estrutura profunda (semântica), codificar o desacordo contido na estrutura profunda ao rearranjar argumentos e elementos formais adequadamente e realizá-lo em uma estrutura de superfície que seja inteligível e aceitável ao interlocutor.

d) Geralmente, apenas parte do que foi dito é contradito, especialmente em formas implícitas de desacordo.

e) $\mathrm{O}$ ato de desacordo pode realizar-se de uma grande variedade de formas e maneiras, desde sinais paralingüísticos e citações processadas com padrões especiais de entoação, até estereótipos sintagmáticos.

f) $\mathrm{O}$ sucesso de uma contradição pode ser diagnosticado pelo efeito perlocucional da interação.

g) Há formas ritualizadas de desacordo, que causam menos reações agressivas, pois sua rígida convencionalização reduz sua capacidade de expressar relações interpessoais.

h) Há diferentes tipos de desacordo, conforme seja dirigido a uma informação fatual, a relações interpessoais ou a modos de expressão lingüística.

O autor comenta ainda sobre o silêncio como expressão de desacordo. Lembra que o desacordo, quando emitido por uma personalidade superior na escala social, pode significar (e geralmente significa) repreensão. Quando expresso por um indivíduo posicionado inferiormente em uma escala de poder, significa protesto e insubordinação. Porém, "mesmo escravos podem contradizer seus donos simplesmente calando-se". Manter silêncio é um ato de comunicação, podendo inclusive ser tomado como um exemplo extremo de comunicação assimétrica. (cf. SoRNIG, 1977: 368). Do mesmo modo, oponentes que possuem e usam códigos e registros de fala considerados de maior prestígio muitas vezes só podem sofrer oposição por meio do silêncio. Assim, o desacordo pode ser expresso também de forma não verbal, por meio de um silêncio significativo, em tais situações.

O artigo de SORNIG, além de ser um dos mais antigos sobre o assunto, é muito claro e abrangente. Seguindo o modelo dos atos de fala, descreve minuciosamente os passos que caracterizam o desacordo, porém não se restringe apenas a isso. Em sua preocupação didática, levanta pontos pertinentes em diversos campos referentes ao desacordo, ao referir-se a diferentes possibilidades de expressão em nível da estrutura de superfície, à sua importância nos níveis semântico, no que diz respeito à noção de 
correção de partes do pré-texto, e pragmático, ao mencionar o papel da hierarquia social e dos registros de fala. Muito importante é a noção da necessidade de um pré-texto, que dá origem ao desacordo e ao qual ele se refere. Porém, o desacordo não se refere necessariamente ao que foi dito, mas sim, ao que "se quis dizer". Assim, pode-se contradizer conteúdos implícitos que não foram apresentados expressamente. Outro ponto muito importante, especialmente para nossa pesquisa, é a menção à existência de formas implícitas e ritualizadas de desacordo.

\subsubsection{APELTAUER, Ernst: "Nichtakkordierende Sprechhandlungen (NASH)" ("Atos de fala não-concordantes")}

O artigo de APELTAUER abre com uma citação de um livro, na qual alguém comenta as diversas formas que utilizava para substituir a palavra não, como: "realmente eu ...", "sabe, eu acho que...", "eu só quero dizer que...", "entende o que eu quero dizer?" (cf. Apeltauer, 1980: 69). Essa é uma boa ilustração tanto do fato de que se pode expressar desacordo de diversas maneiras, como de que muitas vezes é penoso expressar o desacordo abertamente.

Partindo do pressuposto de que uma argumentação só é possível quando há desacordo entre duas ou mais pessoas, o autor propõe-se a investigar tipos de atos de fala (Sprechhandlungstypen) com os quais é expressa a não-concordância, para os quais introduz o termo "nãoconcordantes" (nichtakkordierend), denominando-os "NASH" (nichtakkordierende Sprechhandlungen).

APELTAUER compreende os NASH como atos reativos (i.e. que reagem a um ato iniciador de seqüências) que trazem distúrbios à interação, ao quebrar a expectativa regular dos iniciadores de seqüências e alterar o andamento típico ideal de uma conversação, ou seja, a aceitação das contribuições do interlocutor. Como tal quebra pode levar facilmente a interações conflituosas e agressivas, os NASH são freqüentemente realizados através de alusões ou atos de fala indiretos, os quais são inclusive fortemente ritualizados em algumas sociedades (cf. APELTAUER, 1980: 70).

Segundo a diferenciação de atos reativos em ampliadores ou concluidores de seqüências (runderweiternde und rundbeendende Sprechhandlungen), APELTAUER faz uma distinção idêntica para os NASH. Atos que concluem uma seqüência implicam uma não-aceitação das condições de interação introduzidas ou pressupostas, seja porque há outras 
preferências ou porque outras condições da interação não foram preenchidas (por exemplo, quando normas da interação se opõem à realização de um ato de fala); os NASH que ampliam seqüências aceitam ao menos em parte as condições da interação introduzidas ou pressupostas. Tais NASH podem, ainda, ser subdivididos em atos de fala que atacam ou estabelecem posições (positionsangreifende und positionssetzende Sprechhandlungen). Os vários tipos de NASH estão sistematizados no seguinte esquema:

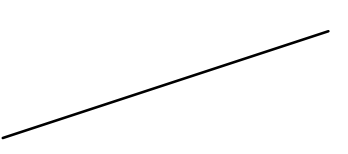

ampliadores de seqüência

(runderweiternd)

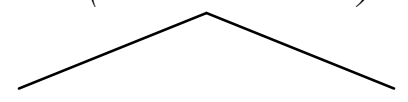

marcadores de posição

(Position setzend)

$\mid$

contradizer

(wider-

sprechen)

contestar

(bestreiten)

considerar

errado

(für falsch erklären) contestadores

de posição

(Position

angreifend)
NASH

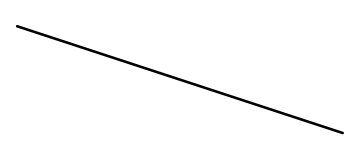

concluidores de seqüência

(rundbeendend)

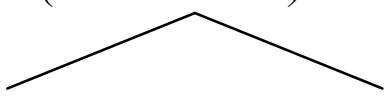

infração das normas

(Regel/Norm

Verletzung) condicionados a preferências (präferenzbedingt)

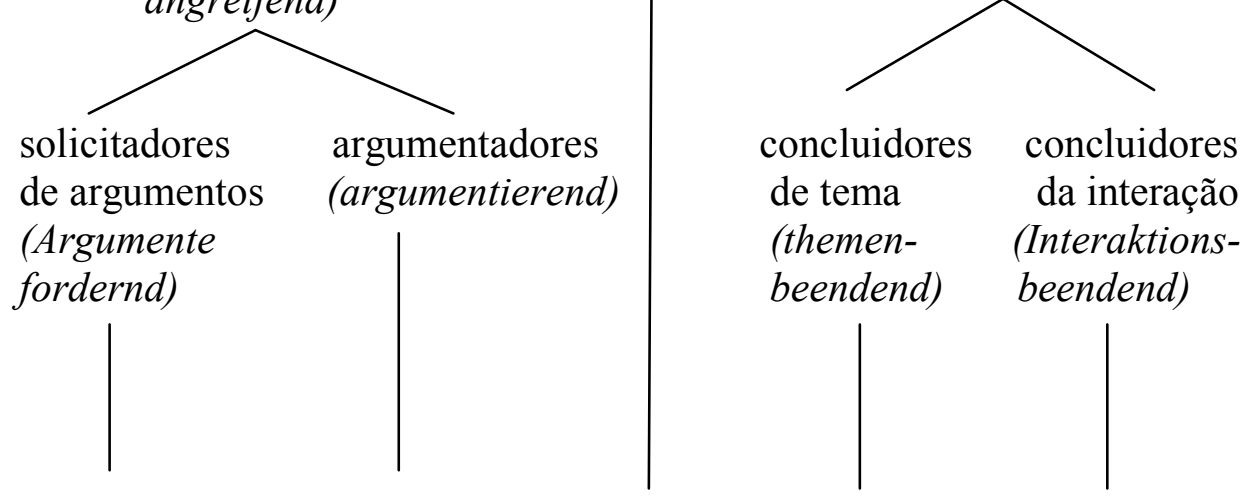

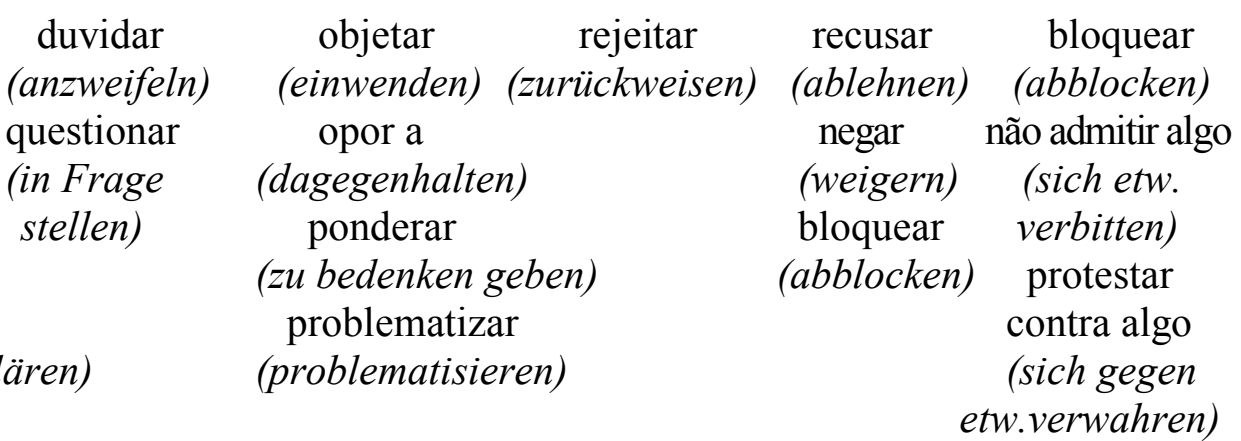

APELTAUER alerta para o fato de que é muito difícil associar cada enunciado a um ato de fala específico. Em interações autênticas, pode haver uma sobreposição de atos de fala com referência a um enunciado, a qual pode causar falta de clareza. Tais problemas podem ser esperados onde são válidas condições de atos semelhantes ou idênticos em parte, como no 
exemplo "eu não preciso justificar-me para você" (ich brauche mich Ihnen gegenüber nicht rechtfertigen), no qual ao mesmo tempo é repelida uma censura (Zurückweisung) e realizado um bloqueio (Abblocken). Para evitar confusões, o autor aponta a necessidade de uma descrição detalhada de cada $\mathrm{NASH}$, fazendo, a seguir, alguns comentários sobre a diferenciação entre zurückweisen (rejeitar), ablehnen (recusar) e weigern (negar), e encerra o artigo com a observação de que o sistema nele apresentado só poderá ser testado e aperfeiçoado através de estudos empíricos de interações concretas e autênticas, as quais também fornecerão as bases necessárias para a diferenciação dos diversos atos de fala.

$\mathrm{O}$ artigo de APELTAUER apresenta diversos atos de fala compreendidos como "atos de fala não concordantes", o que corresponde ao nosso conceito de Dissensão. Embora possa-se discutir se todos os verbos sistematizados no esquema constituem realmente atos de fala distintos, novamente fica claro que todas essas ações têm um traço em comum, o de discordância de um interlocutor. Como SoRNIG, o autor classifica tais ações como reativas e potencialmente perturbadoras da interação, o que justifica a possibilidade de ritualização de sua expressão. $\mathrm{O}$ artigo é extremamente conciso e tem como ponto forte a sistematização de todos esses atos de fala não-concordantes sob um único conceito semântico, a que chamou de NASH, o que permite estudar suas características comuns e diferenciadoras. Outro ponto de grande importância é a ênfase na necessidade do estudo de interações concretas, que permitam a reconstrução do contexto e das pressuposições necessárias para a identificação do desacordo.

\subsubsection{SPRANZ-FogaSY, Thomas: 'Widersprechen' - zu Form und Funktion eines Aktivitätstyps in Schlichtungsgesprächen; eine gesprächsanalytische Untersuchung. ('Contradição' - sobre forma e função de um tipo de atividade em audiências de conciliação; uma investigação à luz da análise conversacional)}

Em seu livro, SpRANZ-FOGASY investiga ocorrências de 'contradições' em um corpus composto de 20 diálogos, sendo a maioria exemplos de audiências de conciliação. Baseado em conceitos da análise da conversação, o autor identifica a ocorrência de contradição como uma manifestação de divergência por parte dos interlocutores a respeito de seus pontos de vista sobre um conteúdo (Sachverhalt) expresso na interação (cf. SPRANZ-FOGASY, 1986:67). 
A primeira parte do livro é dedicada ao estabelecimento da estrutura interna da contradição. Primeiramente, o autor define duas características básicas da contradição, quais sejam:

a) A contradição é reativa ou seja, subordina-se seqüencialmente à contribuição do interlocutor (cf. SPRANZ-FogASY, 1986:17). Como o entendimento sobre conteúdos ocorre seqüencialmente durante a interação, um dos participantes pode introduzir uma representação de um conteúdo que não é partilhada total ou parcialmente pelo interlocutor. Assim, este último pode opor a sua própria visão àquela de seu interlocutor, negando-lhe a ratificação de sua contribuição. O autor sugere inclusive um padrão seqüencial composto de afirmação $\rightarrow$ contradição $\rightarrow$ atividades de negociação (cf. SPRANZ-FOGASY, 1986:18-20).

b) A contradição é adversativa no que se refere a um conteúdo, ou seja, refere-se a um recorte do mundo apresentado lingüisticamente na contribuição de seu interlocutor e dirigida contra essa representação. (cf. SPRANZ-FOGASY, 1986:17)

Partindo dessas duas características, o autor levantou as ocorrências de contradição no corpus, as quais apresentaram dois componentes. $\mathrm{O}$ primeiro é comum a todas as ocorrências de 'contradição': todas contestam a pretensão de validade da representação de um conteúdo sugerida pelo interlocutor. $\mathrm{O}$ segundo componente pode apresentar-se sob três formas: a) através da formulação de uma representação própria do conteúdo em questão, contrária à afirmação do interlocutor; b) de forma a assegurar a validade da representação do conteúdo assumida pelo falante; c) de forma a assegurar a validade da orientação imprimida pelo falante com relação ao conteúdo em questão. (cf. SPRANZ-FOGASY, 1986: 28).

Investigando a estrutura interna da contradição, o autor afirma que ela está sempre ligada a um só turno:

[...] a 'contradição' não pode distribuir-se por diversas intervenções de um interlocutor, mas sim, precisa ser realizada 'de um só golpe'. Quando várias intervenções de um falante referem-se ao mesmo conteúdo com caráter de 'contradição', trata-se, na segunda e demais intervenções, de fenômenos de insistência, ou seja, fenômenos expressivos com outra função, acessória. (SPRANZ-FOGASY, 1986: 22) ${ }^{4}$.

\footnotetext{
${ }^{4}$ [...] 'widersprechen' kann nicht auf mehrere Redebeiträge eines Teilnehmers verteilt werden, sondern muß 'in einem Zuge' realisiert werden.Wenn im Zusammenhang ein
} 
Porém, examinando uma contradição, pode-se estabelecer intuitivamente cesuras que delimitam componentes distintos, como nos exemplos:

nein // das is nischt wahr [não// não é verdade]

isch hab kä"n streit mit der fra ghabt // sie hot misch beleidisch // so is'ses

[eu não briguei com a mulher // ela me ofendeu // é isso aí]

(SPRANZ-FOGASY, 1986: 23)

Tais componentes são organizados pelo autor sob a forma de "técnicas de contradição", definidas como "categorias de ações interpretativas, empregadas durante a execução da 'contradição' " (cf. SPRANZ-FOGASY, 1986: 29).

As técnicas de contradição podem ser agrupadas de acordo com sua função em:

1) técnicas com as quais se rejeita explícita ou implicitamente a pretensão de validade de uma manifestação prévia; e

2) técnicas que servem para assegurar a orientação dada ao conteúdo pelo oponente, já expressa por meio de técnicas do primeiro grupo.

Consideradas isoladamente, as técnicas do segundo grupo não constituem uma contradição e também não podem ocorrer no início de uma ocorrência de contradição (cf. SPRANZ-FoGASY, 1986: 31). Podemos, então, deduzir que estas últimas são técnicas auxiliares ou "estratégias de suporte" da contradição.

SPRANZ-FogASY apresenta uma lista de dez técnicas de contradição, com exemplos e observações sobre os elementos lingüísticos nelas utilizados:

1) Reclamação (Reklamation): Geralmente expressões curtas, com as quais o falante sinaliza ao interlocutor sua não-concordância, sem especificar exatamente a abrangência e a base da rejeição. No corpus, o elemento mais utilizado para expressá-la é nein.

und desselben Sachverhalts mehrere Beiträge eines Teilnehmers 'widersprechens'Charakter haben, so handelt es sich bei dem zweiten und allen folgenden Beiträgen um Insistenzphänomene, also um Äußerungsphänomene mit anderer, noch zusätzlicher Funktion. (SPRANZ-FOGASY, 1986:22) 
2) Julgamento contrário (konträre Beurteilung): Declarações do falante sobre a afirmação do interlocutor. Ex.: das ist falsch/nicht wahr (isso é falso/não é verdade).

3) Avaliação contrária (Gegeneinschätzung): $\mathrm{O}$ falante deixa claro que ele tem uma opinião diferente da do interlocutor, mas não a explicita. Ex.: des glaub isch net - não acredito nisso.

4) Afirmação contrária (Gegenbehauptung): Inversão direta e contraditória da representação do conteúdo do interlocutor; tem a estrutura lógica da contradição (X e não X) e é a técnica mais utilizada no corpus (Ex.: ele vem hoje/ele não vem hoje).

5) Afirmação alternativa (Alternativbehauptung): Afirmação que apresenta uma outra interpretação, incompatível com a validade da afirmação do interlocutor, que a exclui. Ex.: A: A casa é azul - B: A casa é verde.

6) Restrição e Expansão (Einschränkung und Erweiterung): São duas formas de uma técnica que relativiza informações da afirmação em debate (implícitas ou explícitas) passível de gradação. As informações dos participantes tornam-se, assim, incompatíveis (Ex.: ela estava muito nervosa/ela estava pouco nervosa).

7) Fundamentação (Begründung): Formula-se um conteúdo que, através de uma relação causal, deve fazer o conteúdo em debate parecer apenas possível ou totalmente impossível (Ex.: A: - Ontem vi Maria no clube. B: - Maria está na Europa).

8) Esclarecimento (Erläuterung): Apresenta o conteúdo em debate em um contexto tão limitado, que, com isso, aparece como apenas provável ou mesmo improvável (Ex.: A: - Vocês se vêem sempre. B: - Só nos vemos no verão, ainda assim, só quando ele vai ao clube!).

9) Apelação (Berufung): O falante procura reforçar seu ponto de vista através da referência a pessoas ou testemunhas (Ex.: Carla estava lá, ela pode confirmar o que eu digo).

10) Confirmação (Bekräftigung): Utilizada ao fim da intervenção, atua como um sinal de fechamento e entrega do turno (Ex.: so is=es - é isso aí) e serve principalmente para reforçar o que já foi apresentado pelo falante. Geralmente marcado pela entoação.

São estudadas pelo autor diversas possibilidades de combinação dessas técnicas, que podem expressar a contradição de quatro diferentes modos: 
a) Intervenção contrária (Konträre Intervention): Não é formulada nenhuma representação contrária do conteúdo em questão, apenas sinaliza-se ao interlocutor que o falante tem uma opinião contrária, impedindo-se assim a continuação da interação nas bases propostas. As técnicas utilizadas são a Reclamação, o Julgamento contrário e a Avaliação contrária.

b) Polarização (Polarisierung): $\mathrm{O}$ falante formula uma representação contrária do conteúdo em questão (com o mesmo peso da do interlocutor), sendo que uma das representações está na forma negativa. O rumo da interação também é detido, criando-se tensão e ameaçando o prosseguimento da interação. Técnicas utilizadas: Reclamação (opcional) juntamente com Afirmação contrária.

c) Contraste (Kontrastierung): Opõe-se ao interlocutor uma outra interpretação de um conteúdo de modo construtivo e não negativo, que implicitamente exclui a sua representação. Embora sempre seja utilizada a técnica Afirmação alternativa, ela nunca aparece sozinha, sendo sempre precedida de uma das técnicas Reclamação, Julgamento contrário, Avaliação contrária e Afirmação contrária, talvez porque "a idéia cotidiana de 'contradição' precisa de manifestações marcantes e claras, para as quais o uso de sinais de negação pode ser paradigmático" (SPRANZ-FOGASY, 1986: 56). Este modo de contradição abre aos participantes a possibilidade de estabelecer uma definição comum do conteúdo em questão.

d) Dimensionamento contrário (Konträre Dimensionierung): A extensão de validade (quantidade, tamanho, intensidade etc., freqüentemente apenas implícita) da afirmação do interlocutor é restringida ou expandida, servindo freqüentemente para correções locais, principalmente quando pode ser atribuída ao falante maior competência em relação ao tema que a do interlocutor (p.ex., quando se discute sobre carros com um mecânico profissional). Técnica utilizada: Restrição e Expansão.

Na segunda parte do livro, SPRANZ-FOGASY investiga a contradição como um problema para a interação e as formas para sua resolução. Assim, este segundo passo foge ao escopo de nossa pesquisa, e não vamos resenhálo aqui. Como seu corpus é constituído principalmente por encontros de conciliação, o autor deixa em aberto a validade de seus resultados para outros tipos de interação.

SPRANZ-FOGASY restringe seu estudo às ocorrências da contradição, que é apenas um dos 'atos de fala não concordantes' de APELTAUER, 
apresentados no item anterior. Como SoRNIG e APELTAUER, ele também enfatiza as duas características básicas da contradição: o caráter reativo e a adversatividade. O uso de um corpus autêntico fornece-lhe o contexto e o enunciado anterior aos quais se referem as ocorrências examinadas, minimizando os pontos de interpretação duvidosa. Porém, o autor, talvez por investigar apenas 'contradições' em situações de conflito, dedica-se quase exclusivamente ao enunciado imediatamente anterior à contradição.

O livro apresenta também bons exemplos de que uma mesma expressão lingüística pode assumir diversas interpretações, como no seguinte exemplo:

Um simples 'não' pode - de acordo com o contexto - ter significados bem diferentes. [...] Igualmente problemática é uma expressão como isch hab kän streit mit der fra ghabt (eu não briguei com a mulher). Vista em si mesma, podese tratar de uma simples afirmação [...]. Apenas o estabelecimento de uma relação com a declaração anterior fornece esclarecimentos suficientes sobre o seu caráter como contradição:

C: also äns steht fescht daß $\beta=$ der streit ghabt habt (...)

[Bem, uma coisa é certa, que ele teve uma briga (...)]

A: isch hab kän streit mit der fra ghabt [eu não briguei com a mulher]

(SPRANZ-FOGASY, 1986: 19) ${ }^{5}$

Apesar da diversidade de formas da contradição, SPRANZ-FOGASY tentou sistematizá-las em técnicas e em suas possíveis combinações, revelando estratégias conversacionais características da contradição e demonstrando ainda que certas expressões lingüísticas estão subordinadas a determinada técnica, enquanto outras podem ser utilizadas em várias ocasiões. Embora o estudo de SPRANZ-FOGASY ocupe-se exclusivamente de um tipo específico de Dissensão, alguns dos pontos levantados são cruciais para o estudo da Dissensão em geral, a saber: o seu caráter reativo e adversativo e as diversas possibilidades de expressão postas à disposição do falante, que as seleciona conscientemente de acordo com o efeito que pretende obter junto ao interlocutor.

${ }^{5}$ Ein bloßes nein kann - je nach Kontext - ganz unterschiedliche Bedeutungen haben. [...] Ähnlich problematisch ist eine Äußerung wie isch hab kän Streit mit der fra ghabt. Für sich gesehen kann es sich um eine einfache Behauptung handeln [...]. Erst die Herstellung des Bezugs zur voraufgehenden Äußerung gibt genügend Aufschluß über den Charakter der o.g. Behauptung als 'widersprechen' (SPRANZ-FOGASY, 1986:19) 


\subsubsection{KoHnen, Thomas: Zurückweisung in Diskussionen. Die Konzeption einer Sprechhandlungstheorie als Basis einer empirisch orientierten Konversationsanalyse (Rejeição em discussões. A concepção de uma teoria de atos de fala como base de uma análise conversacional empiricamente orientada)}

KOHNEN também se utiliza de elementos da Análise da Conversação como base de seu estudo e sua definição de rejeição parte dos conceitos de ato de fala e de lance. Para ele, a análise da rejeição precisa considerar duas perspectivas: a dos atos de fala em si (como "pergunta", "exortação") e a dos atos de fala com uma determinada função conversacional como reação a um enunciado anterior.

$\mathrm{O}$ autor define um ato de fala como um enunciado através do qual é apresentado um determinado compromisso ou condição da interação (cf. KoHNEN, 1987: 8). Porém, os atos de fala adquirem sua função conversacional apenas quando se tornam lances dentro de uma interação concreta. Lances são "um ou mais atos de fala que têm uma função definida dentro de uma conversação, ou seja, uma função conversacional" (KOHNEN, 1987: 9) ${ }^{6}$. Os lances podem ter funções iniciais (quando um ato de fala do interlocutor a ele se refere) ou reativas (quando o lance se refere a um ato de fala anterior).

A rejeição é definida como "uma classe de lances, com os quais uma condição da interação, apresentada através de um ato de fala prévio (ou através das regras da interação), não é aceita." (cf. KOHNEN, 1987: 10). Em nota de rodapé à página 13 , o autor ressalta que tal definição engloba naturalmente também enunciados que podem ser denominados 'contradição', 'recusa', 'objeção' ou expressões semelhantes. KOHNEN admite ainda a possibilidade de que um lance reativo não se refira apenas a uma condição da interação diretamente anterior, mas também a condições da interação que estão cronologicamente mais afastadas ou que permeiam toda a interação: "Além das funções globais iniciativas e reativas, os lances também se caracterizam por funções conversacionais específicas, que só podem ser explicadas no contexto geral de uma conversa concreta e das intenções e objetivos maiores perseguidos pelo falante" (cf. KOHNEN, 1987: 10) ${ }^{7}$, tais como consideração pelo interlocutor e ameaças à Face, entre outros.

\footnotetext{
${ }^{6}[. .$.$] ein oder mehrere Sprechakte, die eine bestimmte Funktion in einem Gespräch, d.h.$ eine konversationelle Funktion haben. (KOHNEN, 1987: 9)

${ }^{7}$ Über die globalen initiativen und reaktiven Funktionen hinaus zeichnen sich Züge auch durch spezifische konversationelle Funktionen aus, die nur im
} 
O autor exemplifica muito claramente como a rejeição pode apresentar diversas realizações no que se refere aos atos de fala. Pode-se expressar a não-aceitação de um valor de verdade (Wahrheitsanspruch), com a apresentação de uma nova sugestão de valor de verdade, fazendo uma pergunta, dando uma ordem etc. À página 7 encontramos os seguintes exemplos:

A1: A gramática gerativa apresenta a solução definitiva para as questões fundamentais da lingüística.

(Die generative Transformationsgrammatik liefert die endgültige Lösung für die grundlegenden Fragen der Linguistik.)

B1: Ela ainda não consegue nem sequer formular as questões fundamentais.

(Sie kann noch nicht einmal die grundlegenden Fragen formulieren.)

B2: Não há mais nenhuma gramática gerativa.

(Es gibt keine generative Transformationsgrammatik mehr.)

B3: Não se pode dizer isso.

(Das kann man nicht sagen.)

B4: Isso é bobagem.

(Das ist Unsinn.)

B5: Você tem certeza disso?

(Bist du da sicher?)

B6: Não se deveria restringir isso?

(Sollte man das nicht einschränken?)

B7: Pare com isso!

(Hör doch auf!)

KOHNEN conclui, após o exame dos exemplos, que desde que atos de fala de diversas categorias assumem na conversação uma função reativa, de rejeição, pode-se falar em diversas 'formas de realização ilocucional' da rejeição (cf. KOHNEN, 1987: 51).

$\mathrm{O}$ autor analisa ocorrências de rejeições em três debates sobre a Guerra das Malvinas transmitidos pela televisão. Partindo dos diferentes atos de fala que são utilizados para expressá-las, procura relacioná-las com os objetivos maiores perseguidos pelos participantes das interações, com base em seu papel social e na manipulação das Faces. Dentro do gênero "discussão", espera-se que as rejeições atuem como iniciadoras da busca

Gesamtzusammenhang eines konkreten Gesprächs und der übergreifenden Absichten und Ziele, die die Spracher in ihm verfolgen, erklärt werden können. (KOHNEN, 1987:

10) 
cooperativa de uma visão consensual sobre os fatos. Porém, KOHNEN afirma que, freqüentemente, as rejeições são formuladas de modo a atacar a Face dos oponentes e a apoiar a Face positiva do falante, o que já havia sido sugerido por GOFFMAN como "o uso agressivo das técnicas de Trabalho da Face". Esta estratégia é denominada por KOHNEN "estilo de discussão centrado no falante" (Sprecherorientierter Diskussionsstil), oposta ao estilo que tende a minimizar conflitos e buscar o consenso, denominado "estilo de discussão centrado no ouvinte" (Hörerorientierter Diskussionsstil). KOHNEN analisa, então, cada discussão com base nesses estilos e demonstra que em cada grupo há um estilo dominante, que tende a ser seguido por todos os participantes. Um dos três grupos de debates analisados era constituído apenas por falantes alemães; o segundo, apenas por falantes americanos e o terceiro, por falantes ingleses e irlandeses. Embora o autor não discuta possíveis influências culturais no estilo de discussão de cada grupo, não deixa de observar que o grupo alemão tem um estilo fortemente centrado no falante, enquanto os outros grupos tendem ao estilo centrado no ouvinte.

O estudo de KOHNEN, apesar de dedicar-se apenas às rejeições, tem um conceito mais abrangente de não-concordância que a de SPRANZ-FOGASY, ao admitir que sua definição de rejeição aplica-se também a outros atos de fala discordantes e que tal discordância pode-se referir a conteúdos cronologicamente mais afastados no decorrer da interação. Também apresenta exemplos pertinentes de diversas possibilidades de realizações de rejeição, incluindo formas implícitas e indiretas e enfatizando que atos de fala normalmente não ligados à rejeição podem ser utilizados para esse fim, dependendo do contexto em que são empregados. O caráter reativo da discordância é novamente uma noção central, assim como seu caráter de função conversacional referente a enunciados anteriores. KOHNEN também procura sistematizar as ocorrências de rejeição sob a forma de estratégias conversacionais utilizadas pelos falantes. Um aspecto central de seu estudo, e também muito importante para nós, é o fato de que a expressão lingüística das rejeições e outros atos de fala semelhantes pode ser selecionada pelos falantes com base nas relações interpessoais que se deseja estabelecer durante a interação. Também aponta, indiretamente, a possibilidade de haver diferentes regras para a utilização dessas estratégias em diferentes culturas quando, ao final de seu estudo, comenta uma tendência dos falantes alemães para um estilo de discussão centrado no falante, com rejeições mais agressivas, em contraste com uma tendência dos falantes ingleses em favor de um estilo de discussão mais cooperativo, com rejeições atenuadas. 
O estudo de KOHNEN, assim, apresenta vários pontos de contato com o nosso, inclusive considerando o conceito de Face e de manipulação da forma lingüística da Dissensão a fim de obter efeitos referentes à valorização das Faces. No entanto, KoHNEN analisa seus inquéritos como um todo, privilegiando os processos argumentativos desencadeados pelas rejeições e seus efeitos nas estratégias gerais perseguidas pelos participantes das discussões, enquanto que nossa proposta é mais pontual e centrada na expressão de cada Dissensão em particular, a fim de sistematizar suas realizações com referência ao Trabalho da Face

\subsubsection{O Conceito de Dissensão}

Os estudos alemães mais detalhados aqui resenhados, os de SPRANZFOGASY e de KOHNEN, respectivamente sobre contradição (widersprechen) e rejeição (zurückweisen), investigam as expressões mais evidentes de Dissensão, as quais apresentam explicitamente a discordância do falante com relação às idéias do interlocutor. Os estudos de SORNIG e APELTAUER, embora menos detalhados, são mais abrangentes e aproximam-se mais dos objetivos de nosso estudo. Nossa proposta é estudar toda a gradação de Dissensão que possa surgir nos diálogos a serem analisados, englobando desde a "Dissensão total" da contradição e rejeição (widersprechen/ zurückweisen) até dissensões parciais frente ao interlocutor, e identificar possíveis formas/estratégias de expressão lingüística da Dissensão em toda sua gama, conforme surjam no nosso corpus.

Examinando os estudos resenhados, pode-se concluir que todos apresentam em comum os seguintes pontos:

A Dissensão é um fenômeno que:

1. só se manifesta em nível conversacional, havendo a necessidade de mais de um falante e de mudança de turno;

2. é reativo, i.e. sequencialmente subordinado à contribuição anterior de outro falante;

3. é adversativo: i.e., refere-se a um recorte do mundo apresentado pelo oponente e é dirigido contra sua apresentação como um todo ou, ao menos, em parte (cf. SORNIG, 1977: 363 e SPRANZ-FOGASY, 1986: 17)

4. apresenta diversas possibilidades de realização lingüística. 
5. introduz um elemento desestabilizador e potencialmente melindroso na interação devido a fatores metacomunicativos (cf. SORNIG, 1977: 362), os quais podem influenciar a sua expressão lingüística.

Os itens 2 e 3 acima fornecem-nos a chave do conceito de Dissensão: para que haja Dissensão é necessária uma interação entre pelo menos dois participantes, excluindo-se, é claro, os casos de diálogos interiores, nos quais a pessoa pode pesar alternativas excludentes e, de certo modo, "discordar de si mesma".

No entanto, exatamente esta exceção ilustra muito bem um ponto crucial para a Dissensão, a de que os participantes devem divergir, no todo ou em parte, com referência a um conteúdo. Porém, conforme descrito em SPERBER \& WILSON e melhor detalhado no capítulo 2, a comunicação não acontece por meio da decodificação pura e simples de sinais lingüísticos, mas sim, através de inferências e da construção de modelos mentais dos conteúdos a serem transmitidos (cf. SPERBER \& WILSON, 1986). Assim, o falante discorda ou concorda, na realidade, com a sua própria representação do conteúdo que o interlocutor procurou expressar ao formular seu enunciado (do interlocutor). Desse modo, o falante discorda daquilo que ele julga ser a representação mental de um conteúdo ou a intenção comunicativa do interlocutor. $O$ falante pode assim, inclusive, não concordar com a representação de um conteúdo ou com uma intenção que ele (falante) imputa ao interlocutor, mesmo sem que este a apresente explicitamente, e expressar sua Dissensão com respeito a essa representação/intenção. Daí a importância da observação de SORNIG, de que a Dissensão não se refere ao que foi dito, mas ao que se quis dizer, ou, em nossos termos, a Dissensão expressa a atitude do falante com relação àquilo que este julga que o interlocutor quis dizer.

Partindo destas considerações, podemos concluir que a Dissensão não deve ser entendida como um ato de fala, ao contrário da hipótese de trabalho adotada por SORNIG, APELTAUER E KOHNEN, mas sim, como uma atitude proposicional do falante ${ }^{8}$. Isto é claramente demonstrado por Peter von POLENZ, quando se refere à negação. Em um esquema à página 93 de seu livro Deutsche Satzsemantik (Semântica da oração), POLENZ deixa claro que, além da realização concreta da oração, também elementos

\footnotetext{
${ }^{8}$ Agradeço esta observação ao Dr. Hardarik Blühdorn, feita por ocasião de meu exame de qualificação.
} 
extralingüísticos são responsáveis pelo seu conteúdo. Assim, além da proposição, uma oração também encerra a ilocução e a perlocução. A estas, juntam-se ainda a atitude proposicional do falante e um componente denominado por POLENZ "contato e relacionamento" (Kontakt und Beziehung), no qual se insere o conceito de Trabalho da Face (cf. PolEnz, 1985: 69).

\begin{abstract}
A atitude proposicional é descrita por POLENZ como:
"[...] atitudes/posicionamentos do falante/autor com relação ao conteúdo proposicional, desde certeza e suposição, passando por distanciamento e avaliação até desejo, expectativa, esperança etc. [...] Na gramática tradicional, este campo foi abordado como 'modalidade' ou 'subjetividade' [...]" (PolENZ, 1985: 212). ${ }^{9}$
\end{abstract}

É necessário lembrar que a atitude do falante não se restringe apenas à proposição, podendo referir-se a diversas instâncias, tais como o rumo da interação, o tema a ser discutido, a figura do interlocutor etc. Sobre a importância das atitudes proposicionais, cabe aqui ressaltar, novamente, o que é foi exposto no ítem 1.2.2 com referência a SPERBER \& WILSON, de que enunciados não são usados apenas para transmitir pensamentos, mas também para revelar a atitude do falante frente a, ou com relação ao pensamento expresso:

One of the assumptions a speaker intends to make manifest is that she is entertaining some thought with some particular attitude, since it is on this ground that the hearer may be led to entertain a similar thought with a similar attitude. (SPERBER \& WILSON, 1986: 230)

Entre as atitudes proposicionais, POLENZ cita aquelas que se referem à atitude do falante frente ao valor de verdade de uma proposição e considera a negação como uma atitude que contesta o valor de verdade atribuído a uma proposição (cf. PolenZ, 1985: 215-217). Podemos, portanto, considerar que a Dissensão opera de maneira análoga. O falante, ao detectar uma discrepância entre o seu modelo mental, que ele considera o mais adequado, e o modelo que ele julga estar sendo utilizado pelo interlocutor, expressa (por meios lingüísticos ou não) sua atitude de não-

${ }^{9}$ [...] Attitüden /Einstellungen des Sprechers/Verfassers zum propositionallem Gehalt (Aussagegehalt) gemeint, von Gewissheit und Vermutung über Distanzierung und Bewertung bis zu Wollen, Erwarten, Hoffen usw.[...] In der traditionellen Grammatik ist dieser Bereich unter "Modalität" oder "Subjektivität" [...] behandelt worden. (POLENZ, 1985: 212) 
aceitação. Estes modelos podem referir-se tanto à representação de um conteúdo quanto à forma de condução da interação.

Desse modo, podemos definir a Dissensão como uma atitude proposicional de desacordo por parte do falante, referente a conteúdos ou atitudes imputados por ele ao seu interlocutor.

Resumindo, consideramos que a Dissensão tem suas raízes, portanto, em nível pragmático, conforme apontado no esquema de POLENZ. Ela é eminentemente reativa (cf. APELTAUER, SPRANZ-FogASY, KOHNEN), i.e., é uma reação do falante frente a uma suposta divergência quanto aos modelos utilizados pelo interlocutor durante uma interação, sendo que sua expressão pode ocorrer através de meios lingüísticos ou não (cf. SORNIG). Mesmo quando são utilizados meios lingüísticos, o falante tem grande liberdade de formulação (cf. KOHNEN, SPRANZ-FOGASY), porém, na maioria das vezes, são feitas alusões a elementos situacionais ou discursivos surgidos anteriormente no decorrer da interação e que levaram o falante a concluir pela divergência (cf. SORNIG, KOHNEN, SPRANZ-FOGASY). Assim, o primeiro passo do nosso estudo é a análise do material empírico e o levantamento de elementos situacionais e discursivos nos quais o falante expresse discordância por meios lingüísticos, para posterior análise e classificação.

Pertencendo ao âmbito pragmático da comunicação, a expressão da Dissensão tem também efeitos no que se refere ao relacionamento entre os participantes, conforme apontado por SORNIG e KOHNEN, o que leva o falante a selecionar as formas (lingüísticas ou não) mais adequadas ao seu propósito de condução e manutenção da harmonia durante a interação.

Partindo da definição de Dissensão, o passo seguinte de nossa pesquisa é a identificação das ocorrências de sua expressão através de elementos lingüísticos no corpus. Em seguida, analisamos tais ocorrências, observando as Estratégias de Trabalho da Face nelas utilizadas e procurando sistematizar os meios lingüísticos empregados com referência a elas. Para tanto, é necessário primeiramente definir os conceitos de Face e as estratégias utilizadas para preservá-la durante a interação. 


\subsection{O Conceito de Face}

\subsubsection{GRICE e as Máximas da Conversação}

Apenas recentemente, estudiosos da linguagem começaram a admitir que nem sempre há uma identidade entre o que "se diz" e o que "se quer dizer" com determinada formulação lingüística. Na década de 60, H.P. GRICE demonstrou que a linguagem natural é diferente da linguagem artificial usada para notação de conteúdos lógicos (cf. GRICE, 1975). A linguagem natural apresenta elementos aos quais não se pode atribuir um valor de verdade definido, o que permite o surgimento de implicaturas. GRICE utiliza-se desse termo para denominar conteúdos que não estão convencionalmente ligados a determinados enunciados lingüísticos, mas sim, são deduzidos pelos participantes de uma comunicação com base na forma de um enunciado e sua relação com elementos situacionais e não-verbais. Partindo da convicção de que o propósito da linguagem é a comunicação, e que essa comunicação é desejável do ponto de vista dos participantes, GRICE postulou a existência de um Princípio de Cooperação que norteia toda a conversação, expresso da seguinte maneira:

Make your conversational contribution such as is required, at the stage at which it occurs, by the accepted purpose or direction of the talk exchange in which you are engaged. (GRICE, 1975: 45)

Para melhor especificar o "modo requerido", GRICE desenvolveu um conjunto de regras pragmáticas que levariam à forma mais adequada à transmissão de informações durante a conversação. Tais regras, denominadas Máximas de Conversação, foram assim elaboradas (cf. GRICE: 1975: 45-46):

1. Faça sua contribuição tão informativa quanto necessária (para o propósito corrente da conversação); não faça sua contribuição mais informativa do que é necessário (Máxima de Quantidade);

2. Tente fazer sua contribuição verdadeira: não diga o que acredita ser falso; não diga nada sobre o que não tenha evidência adequada (Máxima de Qualidade);

3. Seja relevante (Máxima de Relevância);

4. Seja claro: evite obscuridade de expressão e ambigüidade, seja breve (evite prolixidade desnecessária); seja organizado (Máxima de Modo). 
Segundo GRICE, estas são as regras básicas para uma interação verbal cujo propósito seja "uma troca de informação com um máximo de eficiência" (cf. ibidem, p. 47). As quatro esferas abordadas pelas máximas não são encontradas apenas em interações lingüísticas, mas também em outros casos de comportamento racional que visam a um propósito. Porém, nas situações reais de comunicação, os falantes deliberadamente violam tais máximas de modo ostensivo, com a finalidade de criar implicaturas conversacionais.

\subsubsection{SPERBER \& WiLSON: O princípio de Relevância}

O Princípio de Cooperação, as máximas e a noção de implicatura de GRICE são fundamentais para os estudos da pragmática, desvinculando a linguagem natural da linguagem lógica e abrindo caminho para importantes linhas de pesquisa lingüística, como a Análise do Discurso. Sua intenção de expressar esses conceitos de um modo simples, utilizando-se da linguagem comum ao invés da linguagem formal da lógica, ao mesmo tempo que possibilitou a percepção de aspectos muito complexos da comunicação verbal, é também o ponto mais vulnerável de sua análise, pois muitos dos conceitos têm definições extremamente vagas, ainda intuitivas, o que fez com que suas teorias tenham sido extremamente criticadas. Vários autores têm retomado as idéias de GRICE como ponto de partida para suas reflexões sobre a linguagem, entre eles Dan SPERBER e Deirdre WILSON. Para estes autores, os conceitos de GRICE são muito vagos e não explicitam os mecanismos através dos quais se daria o processamento das implicaturas. Assim, propõem que a noção do Princípio de Cooperação seja substituído pela de um Princípio de Relevância, assim formulado:

Every act of ostensive communication communicates the presumption of its own optimal relevance. (SPERBER \& WILSON, 1986: 158)

Por sua vez, a noção de relevância ótima é entendida do seguinte modo:

a) The set of assumptions $\{I\}$ which the communicator intends to make manifest to the addressee is relevant enough to make it worth the addressee's while to process the ostensive stimulus.

b) The ostensive stimulus is the most relevant one the communicator could have used to communicate $\{I\}$.

(SPERBER \& WiLSON, 1986: 158) 
Portanto, a comunicação lingüística consiste na tarefa de o falante atrair a atenção do ouvinte, através de estímulos ostensivos (no caso, lingüísticos), sendo que o ouvinte tem sempre a expectativa de que o que o falante vai-lhe apresentar é relevante e está sendo apresentado da maneira mais adequada e econômica possível. Não há a necessidade de um pacto de cooperação entre os interlocutores, nem de um tema dominante ou de máximas a serem conscientemente seguidas ou violadas. Partindo do princípio de que tudo que é dito, e o modo como é dito, são relevantes, o ouvinte procura identificar a intenção comunicativa do falante, e atingir uma interpretação que seja a mais consistente com o Princípio de Relevância.

Para SPERBER \& WILSON, a decodificação da forma verbal é apenas o início de um processamento de hipóteses que levará à compreensão do que o falante quer comunicar:

The coded communication process is not autonomous: it is subservient to the inferential process. [...] The semantic representations recovered by decoding are useful only as a source of hypotheses and evidence for the second communication process, the inferential one. [...] if comprehension is defined as a process of identifying the speaker's informative intention, linguistic decoding is not so much a part of the comprehension process as something that precedes the real work of understanding, something that merely provides an input to the main part of the comprehension process. Verbal communication is never achieved merely by the automatic decoding of linguistic signals. (SPERBER \& WILSON, 1986: 176s.)

Desse modo, tanto o que é comunicado indiretamente (as implicaturas de GRICE) como o que é comunicado explicitamente (para SPERBER \& WILSON, explicaturas), envolvem um processo inferencial, baseado nos sinais lingüísticos utilizados pelo falante. Isto pode ser explicitado através de um exemplo (cf. SPERBER \& WILSON, 1986: 179-182):

(1) Mary diz: "O jantar vai esfriar".

(1a) O jantar vai esfriar.

(1b) Mary quer que Peter venha jantar.

A mensagem (1a) é construída inferencialmente, utilizando informação contextual para completar e enriquecer a sua forma lógica (i.e. o conjunto de propriedades lógicas de uma representação conceitual - cf. op.cit., p.72ss.), de modo a obter a forma proposicional de uma asserção. 
Assim, uma assunção é considerada explícita apenas quando ela representa o desenvolvimento de uma forma lógica codificada por um enunciado.

Porém, uma assunção também pode ser comunicada implicitamente. Neste exemplo, partindo-se de (1a) e juntamente com conhecimentos partilhados pelos indivíduos envolvidos na comunicação (como o fato de que a comida costuma ficar ruim ao esfriar e que Mary gostaria que Peter comesse a comida enquanto ela está boa, i.e., quente), Peter pode deduzir que é a implicação contextual (1b) a mais adequada a ser processada nessa situação comunicativa. Pode-se, então, inferir que (1b) é um membro do conjunto de possíveis assunções transmitidas por (1) e que (1b) está sendo comunicada através do enunciado de Mary. Não é um desenvolvimento de uma forma lógica, mas sim, é construída com base em informação contextual, e em particular através do desenvolvimento de esquemas de assunções recuperados da memória enciclopédica, na qual se encontram assunções e expectativas estereotipadas sobre objetos e eventos. (cf. SPERBER \& WILSON, 1986: 88).

Partindo da premissa de que enunciados não são usados apenas para transmitir pensamentos, mas para revelar a atitude do falante frente a, ou com relação ao pensamento expresso (cf. SPERBER \& WILSON, 1986: 10-11 e 230-231), adotamos a seguinte proposta para nortear o nosso trabalho:

We would like to pursue the idea of a natural linkage between linguistic form and pragmatic interpretation [...]. (SPERBER \& WILSON, 1986: 204).

Um bom exemplo de como o falante pode manipular o Princípio de Relevância para expressar sua atitude em relação aos fatos é apresentado por SPERBER \& WILSON às páginas 194-195:

(2a) Peter: "Você dirigiria uma mercedes?"

(2b) Mary: "Eu não dirigiria NENHUM carro caro."

Neste exemplo, Mary não respondeu à pergunta diretamente, ou seja, explicitamente, mas manifestou uma resposta implícita contextualmente, através de dois tipos de implicaturas. Para entender a resposta de Mary, Peter precisa derivar dois tipos de implicaturas:

(3) Uma mercedes é um carro caro

(4) Mary não dirigiria uma mercedes. 
Mary poderia ter expressado sua resposta muito mais rapidamente se tivesse apenas utilizado a formulação (4). Porém, ela deliberadamente escolheu uma formulação que envolve maior esforço de processamento por parte de seu interlocutor. Assim sendo:

It follows from the principle of relevance that in giving the indirect answer [...] the surplus of information given in an indirect answer must achieve some relevance in its own right. (SPERBER \& WILSON, 1986: 197)

O exemplo ilustra como os falantes selecionam sua expressão, visando não apenas à transmissão pura e simples de informação, mas sim, através das implicaturas e da manipulação dos enunciados com base no princípio da relevância, conseguem transmitir também suas atitudes com relação a esses pensamentos. Entre as atitudes que são explicitadas juntamente com a informação, encontra-se um conjunto de comportamentos lingüístico-sociais denominado comumente polidez.

\subsubsection{Robin LaKoff: As Máximas da Polidez}

Desde o trabalho de GRICE, diversos lingüistas dedicaram-se ao estudo de enunciados e elementos lingüísticos que pareciam contrariar as máximas. Muitos enunciados do cotidiano apresentam maior ou menor informação do que necessária (infringindo a máxima da quantidade), expressam conteúdos sobre os quais o falante não tem absoluta certeza (contrariando a máxima da qualidade), abordam conteúdos aparentemente não pertinentes à interação (contra a máxima da relevância) ou apresentam uma forma obscura ou redundante (desprezando a máxima de modo). No item anterior, vimos como essa aparente "violação" das regras é realmente uma manipulação do Princípio de Relevância. Em um artigo de 1973, muitos anos antes da publicação do trabalho de SPERBER \& WILSON, Robin LAKOFF já criticava o sistema de máximas de GRICE, assumindo uma posição que corresponde, em linhas gerais, exatamente ao Princípio de Relevância detalhado no item anterior. Robin LAKOFF questiona que a comunicação ideal, que seguiria todas as máximas de GRICE, seja o tipo de comunicação normal na vida real:

It should be clear to anyone looking at these rules [Grice's] that a normal, interesting conversation violates these rules at every turn: it is the insipid or stiffly formal conversation that hews to them [...]. Rather, speakers seem to 
conspire, using a kind of principle of sanity: 'I assume you're sane, unless proven otherwise, and will therefore assume that everything you do in a conversation is done for a reason [...]'. (LAKOFF, 1973: 297-298).

Porém, mesmo GRICE já admitia a existência de outras regras, as quais também influenciariam a comunicação:

There are, of course, all sorts of other maxims (aesthetic, social, or moral in character), such as 'Be polite', that are also normally observed by the participantes in talk exchanges, and these may also generate nonconventional implicatures. (GRICE, 1975: 47)

Partindo de suas observações, a autora sugere que duas regras de comportamento pragmático têm precedência sobre as Máximas de Conversação de GRICE. Ela as denomina Regras de Competência Pragmática, formulando-as como segue:

1. Seja claro

2. Seja educado

(cf. LAKOFF, 1973: 296)

A autora lembra que nem sempre a aplicação dessas regras contraria as máximas de GRICE. Porém, no caso de conflito entre elas, as Regras de Competência Pragmática teriam precedência sobre as Máximas de Conversação. Por outro lado, pode haver um conflito entre as duas regras pragmáticas e, nesse caso, a preferência por uma ou por outra dependerá das intenções do falante:

[...] if one seeks to communicate a message directly, if one's principal aim in speaking is communication, one will attempt to be clear, so that there is no mistaking one's intention. If the speakers principal aim is to navigate somehow or other among the respective statuses of the participantes in the discourse indicating where each stands in the speaker's estimate, his aim will be less the achievement of clarity than an expression of politeness, as its opposite. (LAKOFF, 1973: 296)

Mesmo assim, Robin LAKOFF afirma que:

[...] when Clarity conflicts with Politeness, in most cases [...] Politeness supersedes: it is considered more important in a conversation to avoid offense than to achieve clarity. This makes sense, since in most informal conversations, actual communication of important ideas is secondary to merely reaffirming and strengthening relationships. (LAKOFF, 1973: 297s.) 
A autora formula então as Regras de Polidez, as quais podem completar-se ou excluir-se mutuamente de acordo com cada situação. São elas:

1. Não imponha

2. Dê opções

3. Faça com que A se sinta bem - seja amigável

(cf. LAKOFF, 1973: 298)

Robin LAKOFF detalha cada uma das Regras de Polidez e cita alguns expedientes, ou seja, elementos sintático-semânticos, que servem como recursos para a expressão de tais regras, pois, segundo ela, a pragmática interage com a sintaxe e a semântica e não pode ser considerada à parte (cf. LAKOFF, 1973: 296).

A Regra 1, não imponha, também significa 'não se intrometa nos assuntos dos outros'. Se um assunto não é de domínio público, deve-se evitálo ou pedir permissão para abordá-lo, ainda que esse pedido seja apenas convencional, como no caso de "posso lhe perguntar quanto custou o seu vestido?", onde o pedido de permissão já apresenta o assunto que se quer abordar. LAKOFF cita também como exemplos de recursos lingüísticos da Regra 1 o uso da voz passiva, de expressões impessoais, de palavras técnicas para temas tabus e de pronomes de tratamento como vós/vous/usted/Sie (nas línguas que fazem tal distinção). Tais artifícios criam um distanciamento entre os interlocutores, ou entre os interlocutores e a mensagem, reduzindo o grau de envolvimento emocional e aumentando a sensação de objetividade, transmitindo assim, aos interlocutores, a sensação de que suas opiniões íntimas não estão sendo diretamente discutidas.

$\mathrm{Na}$ Regra 2, dê opções, evita-se impor a opinião do falante ao interlocutor, permitindo-lhe chegar, mesmo que apenas aparentemente, às suas próprias decisões. Alguns dos expedientes lingüísticos desta regra são partículas atenuadoras conhecidas como hedges (como 'um pouco', 'bastante' etc) e também o uso de eufemismos, tag-questions e expressões como 'eu creio...', 'eu acho...'. Nestes casos, a autora observa que "seja por polidez ou porque o próprio falante realmente não sabe a resposta, tais sentenças deixam a decisão final sobre a veracidade da sentença para o interlocutor" (cf. LAKOFF, 1973: 300).

A Regra 3, seja amigável, contrasta diametralmente com a Regra 1: enquanto esta procura um certo distanciamento entre os interlocutores, a Regra 3 busca uma aproximação entre os mesmos, criando a sensação de 
igualdade e camaradagem. Exemplos de meios lingüísticos para a aplicação desta regra são o uso de prenomes e apelidos, da forma tu/du nas línguas que a possuem, a distribuição de elogios e cumprimentos, o uso de gírias e palavras tabus, assim como de expressões como 'você sabe...', 'quero dizer...', que visam a expressar os sentimentos do falante sobre o que ele está comunicando e fazer do ouvinte um participante mais ativo de seus pensamentos e sentimentos.

Robin LAKOFF atenta para a necessidade de selecionar adequadamente a regra de polidez com relação ao interlocutor e à situação de comunicação: "em uma situação onde esperaríamos $R$ [egra] 3 e temos $\mathrm{R} 1$, o efeito é mais de uma quebra de cortesia do que a de uma livre escolha entre isso e uma recusa (polida) a impor-se" (cf. LAKOFF, 1973: 302).

Com relação à escolha da regra a seu usada, a autora antecipa uma crítica à sua teoria, a de que culturas e mesmo pessoas dentro de uma mesma cultura têm diferentes padrões de polidez. Porém, ela reafirma que tais regras são universais, mas que, "[...] no caso em que duas culturas diferem em sua interpretação da polidez de uma ação ou de um enunciado, [o que acontece] é que elas têm as mesmas três regras, mas diferente ordem de preferência entre elas" (cf. LAKOFF, 1973: 303). Assim, enquanto algumas culturas ou indivíduos preferem o distanciamento, outros consideram a aproximação como a estratégia padrão de cortesia.

Portanto, os falantes também levam em conta, na formulação de seus enunciados, além do Princípio de Relevância, regras sociais que podem influenciar a interação e a relação pessoal com o interlocutor. SPERBER \& WILSON mencionam que "o estilo é o relacionamento" (cf. SPERBER \& WILSON, 1986: 217), ou seja, através do estilo da comunicação, pode-se reconhecer o grau de mutualidade da relação entre os falantes, a distância social e afetiva entre eles. Os mesmos autores admitem a importância que os falantes atribuem à escolha do estilo e seus efeitos na interação:

The more information she [o falante] leaves implicit, the greater the degree of mutual understanding she makes it manifest that she takes to exist between her and her hearer [...]. It is not always easy to strike the correct balance: even a slight mismatch between speaker's estimate and hearer's abilities may make what was intended to be helpful seem patronising or positively offensive to the hearer. (SPERBER \& WILSON, 1986: 218).

Este efeito desagradável, porém nem sempre acidental, tem origem em comportamentos sociais descritos de forma pertinente por GOFFMAN, os 
quais têm grandes repercussões na organização de processos comunicativos e na seleção da expressão lingüística. Em seu artigo, Robin LAKOFF menciona GOFFMAN rapidamente e, embora o nome deste não conste de suas referências bibliográficas, pode-se perceber claramente que suas reflexões estão na base do desenvolvimento do conceito de polidez de LAKOFF e de suas regras.

\subsubsection{Erving Goffman e o Conceito de Face}

O sociólogo americano Erving GOFFMAN publicou em 1967 o livro Interaction rituals, no qual apresenta sua idéia de Face, assim denominada com base em uma expressão inglesa (to lose face) que tem correspondentes em várias culturas, significando a perda da reputação ou da honra. Segundo ele, os seres humanos vivem em um universo de contatos sociais com outros indivíduos. Todo indivíduo inicia uma interação com uma imagem positiva de si próprio e de sua posição na interação/sociedade, descrita por GOFFMAN como "um valor social positivo, [...] uma auto-imagem transcrita em termos de qualidades reconhecidas socialmente". (cf. GoFFMAN, 1986: 10)

Durante a interação, o indivíduo espera que os seus interlocutores respeitem sua auto-imagem assim como ele respeita as dos demais. Para esse comportamento, GOFFMAN cunhou o conceito de Face, o qual compreende os dois aspectos complementares de respeito à própria imagem e de consideração pela auto-imagem do outro:

Assim como se espera de um membro de qualquer grupo que ele tenha respeito próprio, assim também se espera que ele mantenha um padrão de consideração; espera-se que ele se esforce por resguardar os sentimentos e a imagem dos outros presentes [...]. O efeito combinado da regra de auto-respeito e da regra de consideração é que a pessoa tende a conduzir-se durante um encontro de modo a sustentar tanto a sua imagem como as dos demais participantes (GOFFMAN, 1986: $15-16) .{ }^{10}$

No decorrer da interação, o falante procura manter sua auto-imagem através de "uma estratégia de comportamento bem definida, um padrão de ações verbais e não-verbais que exprimem seu julgamento da situação e,

\footnotetext{
${ }^{10}$ So wie vom Mitglied jeder Gruppe erwartet wird, Selbstachtung zu zeigen, so wird von ihm erwartet, einen bestimmten Standard von Rücksichtnahme aufrecht zu erhalten; man erwartet von ihm, daß er sich bis zu einem gewissen Grad bemüht, die Gefühle und das Image andererAnwesender zu schonen [...]. Die doppelte Wirkung der Regel der Selbstachtung und Rücksichtsnahme besteht darin, daß jemand sich bei einer Begegnung tendenziell so verhält, daß er beides währt: sein eigenes Image und das der anderen Interaktionspartner. (GOFFMAN, 1986: 15-16).
} 
através disso, sua avaliação dos participantes, principalmente dele próprio" (cf. GofFMAN, 1986: 10). Tais estratégias podem ser seguidas consciente ou inconscientemente, mas sempre é adotada uma estratégia em cada interação. Tais estratégias tendem a institucionalizar-se de acordo com a natureza da interação e o status social dos participantes. Espera-se de cada participante que ele mantenha um certo nível de consideração pela Face dos demais participantes, com base em uma identificação espontânea e voluntária com os sentimentos dos demais. Em uma nota de rodapé, GOFFMAN observa que "provavelmente, quanto mais poder e prestígio os outros possuem, tanto mais consideração é mostrada pelos seus sentimentos" (cf. ibid., p.15). Porém, como todos os participantes estão igualmente sujeitos às regras de respeito à sua Face e às dos demais, o resultado é um relativo equilíbrio, "no qual cada um aceita temporariamente a estratégia dos demais" (cf. ibid., p. 16).

Esta aceitação mútua das estratégias de comportamento tem um importante efeito estabilizador em encontros sociais, pois os participantes tendem a evitar ou minimizar os efeitos de situações desestabilizantes nas interações, as quais são descritas por GoFFMAN como "acontecimentos, cujas implicações simbólicas efetivas ameaçam a Face" (cf. idib., p.18). Assim, existem técnicas específicas que visam a restabelecer o equilíbrio das Faces frente a tais situações. GOFFMAN menciona como técnicas de Trabalho da Face os processos evasivos, pelos quais temas e situações constrangedoras são evitados totalmente ou apresentados de forma dissimulada ou indireta, e os processos corretivos, (nos quais comportamentos ritualísticos são adotados para compensar o dano causado à Face de um ou mais participantes), sendo que a intensidade e duração de tais correções correspondem à intensidade da ameaça (cf. ibid., p. 25).

É interessante notar que tais técnicas, que visam a salvaguardar as Faces de ameaças durante a interação, podem também ser utilizadas pelo falante, como descreve GofFMAn, exatamente para atacar as Faces dos interlocutores e fortalecer, assim, a sua própria Face à custa das dos demais. Tal comportamento é denominado pelo autor como "uso agressivo das técnicas deTrabalho da Face". Quando isso acontece,

[...] um encontro ou empreendimento tornam-se menos uma cena de consideração mútua que uma arena de competições ou jogos. O objetivo do jogo é preservar a própria estratégia de uma oposição indesculpável, enquanto se 
procura atribuir tantos pontos negativos quanto possível aos oponentes e tantos pontos positivos quanto possível a si próprio. Para esta disputa, um público é quase uma necessidade (GOFFMAN, 1986: 31). ${ }^{11}$

Assim, a situação ideal de equilíbrio e de respeito mútuo às Faces dos participantes, evitando-se situações embaraçosas e conflitos, nem sempre é mantida. Porém, as regras do jogo de manutenção da Face parecem ser respeitadas na maioria dos casos (como aponta R. LAKOFF ao afirmar que, em caso de um conflito entre ambas, a polidez é mais importante que a comunicação de informações), pois as sanções sociais oriundas do desprezo pela Face dos demais são geralmente fatais para a integração do indivíduo em seu grupo. Assim, a avaliação da situação e o domínio e utilização correta das Estratégias de Trabalho da Face (definidos por GOFFMANN com o termo face work) são extremamente importantes para o indivíduo. Tais estratégias, mencionadas por GOFFMAN como processos evasivos e corretivos, foram posteriormente ampliadas e detalhadas em 1978 em um artigo de Penelope Brown e Stephen LEVINSON.

\subsection{O Trabalho da Face}

\subsubsection{Brown \& Levinson: as Estratégias de Polidez}

BROWN \& LEVINSON, ao invés de considerar a Face como o respeito a normas ou valores consagrados por membros de uma sociedade, preferem considerá-la como um conjunto de necessidades inerentes aos seres humanos de qualquer sociedade. Todos sabem que tais necessidades são desejadas pelo outro e que normalmente é do interesse de cada membro do grupo satisfazê-las, ao menos em parte (cf. BROWN \& LEVINSON, 1978: 67). Assim, as duas regras básicas do conceito de Face de GOFFMAN são redefinidas como conceitos de Face positiva e negativa:

${ }^{11}$ [...] dann wird eine Begegnung oder ein Unternehmen weniger eine Szene gegenseitiger Rücksichtnahme sein als eine Arena von Wettkämpfen oder Spielen. Das Ziel des Spieles ist, die Strategie eines jeden vor einem unentschuldbaren Widerspruch zu bewahren, wobei man freilich möglichst viele Minuspunkte für seinen Widersacher sammelt und möglischst viele Pluspunkte für sich selbst. Für diesen Kampf ist ein Publikum fast eine Notwendigkeit. (GOFFMAN, 1986: 31) 
Face negativa: a necessidade de cada 'membro adulto competente' [de uma sociedade] de que suas ações não sejam obstruídas pelos demais.

Face positiva: a necessidade de cada membro do grupo de que suas necessidades sejam desejáveis ao menos para alguns outros.

(cf. BROWN \& LEVINSON, 1978: 67)

Para apresentarem sua teoria sobre padrões universais de polidez, BROWN \& LEVINSON partem de um indivíduo-modelo dotado de Face e de racionalidade. Às páginas 64 e 65, os autores apresentam um sumário dos argumentos básicos de sua proposta:

1. Todos os indivíduos-modelos (MP, do inglês model person) têm Face positiva e negativa e são agentes racionais (i.e. escolhem meios para satisfazer seus fins);

2. É de interesse mútuo dos MPs manter respectivamente suas Faces, a menos que o falante ( $\mathrm{S}$, do inglês speaker) possa manter sua Face sem compensação para o ouvinte (H, do inglês hearer), por meio de coerção ou truques;

3. Alguns atos ameaçam intrinsecamente a Face (denominados FTAs Face threatening acts);

4. A menos que o interesse de $\mathrm{S}$ em executar o FTA com a máxima eficiência seja maior que o seu interesse em preservar a Face em qualquer grau, $\mathrm{S}$ procurará minimizar a ameaça à Face implícita no FTA;

5. O MP tem à sua disposição um conjunto de estratégias para execução dos FTAs; de acordo com o grau de ameaça do FTA para a Face, S escolherá uma estratégia que lhe permita oferecer compensações mais adequadas para minimizar os riscos do FTA.

6. Desde que 1 a 5 são pressupostos pelos MPs, ele não escolherá uma estratégia com grau maior do que o necessário, pelo risco de fazer o FTA parecer mais ameaçador do que realmente é.

Baseados nas Regras da Polidez de R. LAKOFf e no desdobramento do conceito de Face de GOFFMAN, BROWN \& LEVINSON identificam diversas estratégias para executar os FTAs, as quais são apresentadas no seguinte esquema: 


\section{ESTRATÉGIAS PARA EXECUÇÃO DO FTA}

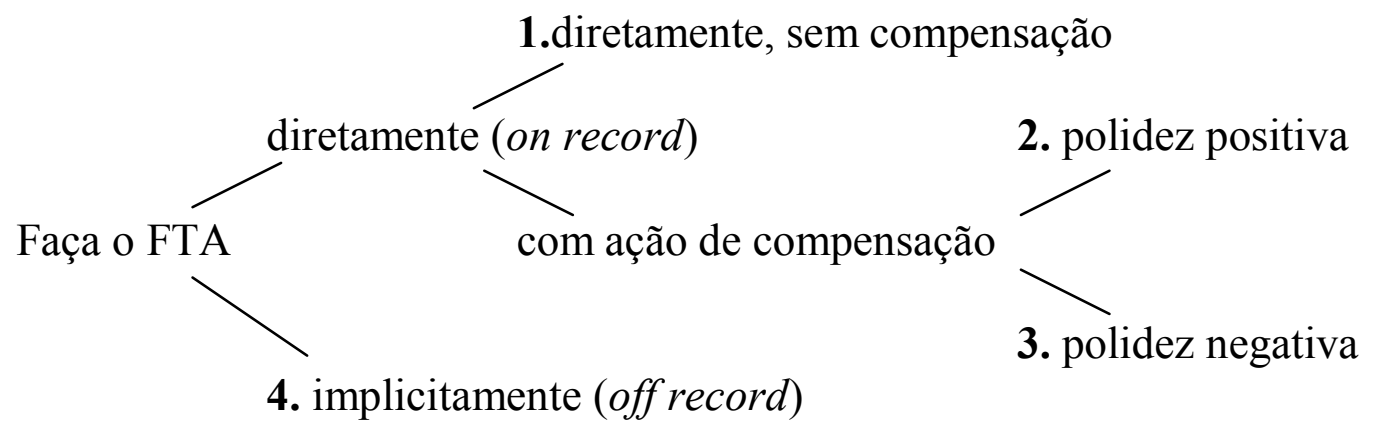

5. Não faça o FTA

(cf. BROWN \& LEVINSON, 1978: 74)

O esquema pode ser explicado da seguinte maneira: partindo-se da resolução de fazer o FTA, o falante pode escolher fazê-lo direta ou implicitamente. No primeiro caso, terá a opção de fazê-lo diretamente e sem compensação, usando a estratégia de número 1, ou acompanhado de uma ação de compensação, de modo a deixar claro ao interlocutor que o falante sabe que sua ação é um FTA, mas que ele não deseja que a sua realização afete a interação ou o relacionamento entre ambos. Essa ação de compensação pode basear-se na polidez positiva, que procura alimentar a Face positiva do interlocutor (estratégia 2) ou na polidez negativa, que enfatiza o respeito à Face negativa do interlocutor (estratégia 3). Por outro lado, o falante pode decidir-se a realizar o FTA de forma não explícita (estratégia 4) ou optar por desistir de realizar o FTA, como indica a estratégia 5. Quanto maior o número que caracteriza a estratégia de polidez, mais indireta e mais atenuada será a realização do FTA, até chegar à estratégia 5. Esta estratégia implica em deixar de executar determinada ação pelo fato de ela ameaçar (na visão do falante) de tal modo a interação, que não há atenuação suficiente para os efeitos negativos que a sua realização causaria ao relacionamento entre os participantes da interação.

Note-se que polidez positiva é considerada mais arriscada que a polidez negativa, pelas seguintes razões: a polidez positiva tem ação compensatória, atendendo à necessidade do ouvinte de que outras pessoas compartilhem alguns de seus desejos particulares. BROWN \& LEVINSON atentam para o fato de que tais desejos são

[...] obviously highly culture-specific, group-specific and ultimately idiosyncratic. Nevertheless there do exist (in general) well defined areas of common ground between any two persons of a society [...]. Still, however well- 
defined these areas are, to assume that (say) I am in the set of persons who will please you by commenting on your clothes is to make an extremely vulnerable assumption, one that may cause affront. It is largely because of this that attention to positive face in a society is often highly restricted. (BROWN \& LEVINSON, 1978: 68s.).

Para seguir esta estratégia, o falante precisa pressupor que ele é um membro do grupo no qual o interlocutor se inclui; a eficácia de sua compensação é totalmente vulnerável à concordância do interlocutor nesta pressuposição. A polidez negativa, por outro lado, é endereçada a um desejo generalizado de liberdade de ação. Compensando o interlocutor nesta moeda, o falante não faz pressuposições vulneráveis e não efetua nenhuma ação compensatória que não seja imediatamente relevante à imposição do FTA (tornando-se, assim, invulnerável a acusações de adulação irrelevante etc.).

\subsubsection{Leech e o Princípio de Polidez}

Em qualquer trabalho que enfoque a polidez, a obra de LEECH Principles of Pragmatics (1983) não pode deixar de ser mencionada. Seguindo a mesma linha de desenvolvimento, partindo de GRICE e Robin LAKOFF e passando por BROWN \& LEVINSON, LEECH propõe um Princípio de Polidez que, juntamente com um Princípio de Ironia (também postulado por ele) e o Princípio de Cooperação de GRICE, determinariam pragmaticamente a interação lingüística. Do Princípio de Polidez, LEECH deriva seis máximas, as quais são relacionadas a atos ilocutórios específicos:

(I) TACT MAXIM (in impositives and commissives)

(a) Minimize cost to other [(b) Maximize benefit to other]

(II) GENEROSITY MAXIM (in impositives and commissives)

(a) Minimize benefit to self [(b) Maximize benefit to other]

(III) APPROBATION MAXIM (in expressives and assertives)

(a) Minimize dispraise of other [(b) Maximize praise of other]

(IV) MODESTY MAXIM (in expressives and assertives)

(a) Minimize praise of self [(b) Maximize dispraise of self]

(V) AGREEMENT MAXIM (in assertives)

(a) Minimize disagreement between self and other

[(b) Maximize agreement between self and other]

(VI) SyMPATHY MAXIM (in assertives)

(a) Minimize antipathy between self and other

[(b) Maximize sympathy between self and other]

(LEECH, 1983: 132) 
A mais importante dessas Máximas é a Máxima do Tato, a qual atua com base em três escalas, a saber:

I. The COST - BENEFIT SCALE on which it is estimated the cost or benefit of the proposed action $\mathrm{A}$ to $\mathrm{s}$ [peaker] or to $\mathrm{h}$ [earer].

II. The OPTIONALITY SCALE on which illocutions are ordered according to the amount of choice which $\mathrm{s}$ allows to $\mathrm{h}$.

III. The INDIRECTENESS SCALE on which, from s's point of view, illocutions are ordered with respect to the length of the path (in terms of means-ends analysis) connecting the illocutionary act to its illocutionary goal. (LEECH, 1983: 123)

Considerando estas três escalas, o autor resume, à página 127 , o modo como tais parâmetros influenciam a Máxima do Tato:

(i) quanto maior o custo de uma ação para o ouvinte,

(ii) quanto maior a distância horizontal do falante em relação ao ouvinte,

(iii) quanto maior o status autoritativo do ouvinte com respeito ao falante;

(iv) tanto maior será a necessidade de dar opções e, correspondentemente, de ser indireto, na expressão de uma imposição, se o falante quiser observar a Máxima do Tato.

As fontes das considerações de LEECH são bastante claras, quando se examina a literatura citada em sua obra. As suas maiores contribuições para o tema, ao nosso ver, são a ênfase na natureza escalar das relações que regem a polidez e na sua interação, sendo que o falante e o interlocutor devem pesar todos os diferentes fatores para a produção e interpretação de enunciados. É também importante o destaque da "assimetria" entre falante e interlocutor em relação ao custo-benefício de uma ação, sendo que esta relação define o grau de polidez a ser utilizado em um enunciado, de acordo com os objetivos dos participantes da interação. Para o autor, a polidez parece ser expressa principalmente em termos de aumentar o grau de opção oferecido ao interlocutor e o esforço em empregar formulações crescentemente indiretas.

O modelo de LEECH não será utilizado, porém, neste trabalho, pelos seguintes motivos:

1. o autor baseia-se na Teoria dos Atos de Fala, relacionando estreitamente suas Máximas de Polidez a atos ilocutórios específicos. Conforme demonstramos no item 1.1.2, a Dissensão não é um ato ilocutório, e sim a expressão de uma atitude do 
falante. Desse modo, um modelo que esteja de tal forma ligado ao conceito de ato ilocutório não é o mais apropriado para a análise da Dissensão;

2. a proposta de mais dois Princípios, juntamente com o Princípio de Cooperação de GRICE, e de seis Máximas distintas para a polidez, parece-nos ter sido suplantada, em termos de economia, pelas considerações de SPERBER \& WILSON sobre o Princípio de Relevância apresentado no item 2.2, o qual dá conta de todas as possibilidades sugeridas por LEECH para o uso de polidez e ironia;

3. as Máximas de Polidez de LEECH e as reflexões que baseiam suas escalas de custo-benefício, opção e indirectness encontram-se também, apenas apresentadas de modo diferente, nos trabalhos de R. LAKOFF e de BROWN \& LEVINSON;

4. as diversas estratégias propostas por BROWN \& LEVINSON englobam todas as Máximas de Polidez de LEECH e possibilitam, por sua apresentação mais detalhada, um estudo mais preciso da realização lingüística da Dissensão em relação ao Trabalho da Face.

Por estes motivos, baseamo-nos, para este trabalho, no estudo e nas estratégias de polidez de BROWN \& LEVINSON para a análise do Trabalho da Face nas expressões da Dissensão em diálogos do Alemão.

\subsubsection{Os conceitos de Trabalho da Face e de Polidez}

Partindo das considerações de R. LAKOFF, BROWN \& LEVINSON denominaram "polidez positiva/negativa" aos procedimentos de aproximação ou afastamento do falante frente ao interlocutor. Porém, o termo "polidez" está coloquialmente associado a diversas conotações que fogem à idéia central do esforço de ambos os participantes de uma interação em preservarem mutuamente suas Faces. Tais considerações também já haviam sido levantadas por outros autores que se ocuparam do tema, como House \& KASPER (1981), LeECH (1983) e Held (1995). Ao propor seu Princípio de Polidez, LEECH faz a seguinte observação:

This discussion has perhaps indicated some dangers in the use of the term 'politeness'. There is an unfortunate association of the term with superficially 'nice', but ultimately insincere, forms of human behaviour, and it is therefore 
tempting to write off politeness (at least in some cultural environments) as being a trivial and dispensable factor which is no more than a 'garnish' on the serious use of language [...] (LEECH, 1980: 83).

Outra possibilidade de entendimento do termo "polidez", além de um conjunto de comportamentos ligados à insinceridade, é aquele, mais positivo, que evoca conotações de gentileza, respeito e consideração. Embora o uso adequado das estratégias propostas por BROWN \& LEVINSON implique, na maioria das vezes, tais atitudes com relação ao interlocutor, as estratégias de polidez também podem sem usadas, como mencionado por GOFFMANN, em ataques e agressões ao interlocutor, o que normalmente não é associado ao conceito corriqueiro de "polidez". LEECH observa o mesmo ao referir-se ao uso de ironia (ibidem).

Ao nosso ver, é necessário adotar um termo conotativamente mais neutro para o objeto desta pesquisa. Nosso objetivo não é estudar apenas o uso de estratégias na "atenuação" de ações potencialmente danosas às Faces, ou ainda, apenas como fórmulas de rotina que expressem deferência ou apreciação para com o interlocutor. Por esse motivo, priorizamos o termo Estratégias de Trabalho da Face, que une os conceitos de facework de GofFMANN e das estratégias de polidez de BROWn \& LEVINSON. No entanto, como os conceitos de polidez positiva e negativa já se firmaram na literatura sobre o tema, manteremos estes termos quando nos referirmos às motivações que determinam o desenvolvimento e o uso das diversas Estratégias de Trabalho da Face.

\subsubsection{A seleção das Estratégias de Trabalho da Face pelo falante}

De acordo com BROWN \& LEVINSON, dois fatores influenciam a seleção das Estratégias de Trabalho da Face: variáveis sociológicas e as recompensas proporcionadas pelas diversas estratégias, sendo que três variáveis sociológicas são computadas intuitivamente pelo MP para julgar a seriedade de um FTA e selecionar a estratégia mais adequada a cada situação:

a) a "distância social"(D) de $\mathrm{S}$ e H (uma relação simétrica).

b) o "poder" relativo (P) de $\mathrm{S}$ e H ( uma relação assimétrica).

c) o valor absoluto na escala (ranking) (R) da imposição na cultura particular. 
As estratégias apresentadas no esquema anterior proporcionam diferentes compensações em termos de ganho de Face (ou minimização dos riscos implicados pelos FTAs). O primeiro passo para o falante, após decidir-se por realizar o FTA, é escolher entre a possibilidade de realizá-lo implicita ou explicitamente. A seguir, apresentamos algumas considerações básicas levantadas por BROWN \& LEVINSON sobre as diversas estratégias e as compensações que oferecem ao falante quando de sua utilização (cf. BROWN \& LEVINSON, 1978: 73-80):

1) Um agente atua diretamente realizando um ato A, quando está claro para os participantes qual intenção comunicativa levou o agente a fazer A. Ex.: "Eu (aqui) prometo vir amanhã", quando o falante tem a intenção de comprometer-se a realizar tal ação futura. Ao utilizar-se desta estratégia, o falante transmite ao interlocutor uma sensação de clareza, transparência e eficiência, demonstrando confiança no interlocutor e intenção de não manipular a interação, recebendo, assim, crédito por sua honestidade, podendo inclusive obter apoio de um possível público contra o interlocutor a próprio favor, no caso de uma disputa.

2) Em contraste, quando o agente realiza o ato A implicitamente, então, há mais de uma intenção atribuível, de modo que não se pode imputar ao agente ter-se comprometido com uma intenção particular. Por exemplo, quando um falante diz a um amigo: "Droga, eu estou sem dinheiro e esqueci de ir ao banco hoje", ele pode ter a intenção de pedir algum dinheiro emprestado, mas não se pode imputar-lhe tal intenção. Realizações lingüísticas de estratégias off record incluem metáforas e ironia, perguntas retóricas, atenuações, tautologias, todos os tipo de "pistas" com respeito àquilo que o falante quer ou pretende comunicar, sem fazê-lo diretamente, de modo que o significado é, em certa medida, negociável. $\mathrm{O}$ uso desta estratégia garante ao falante crédito por seu tato e disposição de não-coerção, além de evitar a responsabilidade de uma interpretação única, possivelmente danosa à Face. Desse modo, o falante pode ainda satisfazer a Face negativa a um grau maior que o permitido pelas estratégias de polidez negativa. Fazer o FTA implicitamente permite-lhe, ainda, fugir ao inevitável comprometimento, à responsabilidade por sua ação presente nas estratégias diretas. 
Caso o falante decida-se por realizar o FTA diretamente, ele pode fazê-lo com ou sem uma ação de compensação:

3) Fazer um ato diretamente, sem compensação, envolve fazê-lo da maneira mais direta, clara, inequívoca e concisa possível, podendo ser, a grosso modo, identificado com as especificações do Princípio de Cooperação de GRICE. Normalmente, um FTA será feito dessa maneira somente se o falante não teme retribuição do interlocutor, p.ex. em circunstâncias onde (a) tanto o interlocutor como o falante concordam tacitamente que a relevância que a Face exige pode ser suspensa frente a interesses como urgência ou eficiência; (b) onde o perigo à Face do interlocutor é muito pequeno, como em ofertas, pedidos e sugestões que são claramente do seu interesse e não requerem grandes sacrifícios do falante; e (c) quando o falante é muito superior ao interlocutor em poder, ou pode conseguir suporte da audiência suficiente para destruir a Face do interlocutor sem perder a sua própria.

4) Por ação de compensação entende-se uma ação que "dá Face" ao interlocutor, i.e., que tenta combater o dano potencial do FTA à Face, realizando-o de tal modo, ou com modificações ou adições tais que indiquem claramente que tal ameaça não é intencional ou desejada, e que o falante em geral reconhece as necessidades de Face do interlocutor e também quer que elas sejam atingidas. Tais ações de compensação tomam uma de duas formas, dependendo de que aspecto da Face (positiva ou negativa) é enfatizado:

a) A polidez positiva é orientada para a Face positiva do interlocutor e é baseada na aproximação entre os participantes da comunicação. A ameaça potencial à Face é minimizada neste caso pela garantia de que, em geral, o falante considera o interlocutor, em aspectos importantes, como "igual" a ele, com direitos e deveres grupais e expectativas de reciprocidade, ou implicando que o falante aprecia o interlocutor, de modo que o FTA não significa uma avaliação negativa em geral da Face deste último. Assim agindo, o falante minimiza os aspectos de ameaça à Face do interlocutor, assegurando que o considera como um igual, que ele é apreciado e suas necessidades são partilhadas pelo falante.

b) A polidez negativa, por outro lado, é orientada principalmente para satisfazer parcialmente a Face negativa do interlocutor, seu desejo básico de manutenção das reivindicações de território e 
auto-determinação. É essencialmente baseada na manutenção de distanciamento, e a realização de suas estratégias consiste em afirmações de que o falante reconhece e respeita as necessidades da Face negativa do interlocutor e não irá interferir (ou apenas minimamente) com sua liberdade de ação, sendo caracterizada por auto-desvalorização, formalidade e controle, com atenção a aspectos muito restritos da auto-imagem do interlocutor, centrando-se em seu desejo de não ser restringido. Há, contudo, uma tensão natural na polidez negativa entre (a) o desejo de agir explicitamente, como um pré-requisito para ser visto "alimentando a Face", e (b) o desejo de agir implicitamente para evitar a imposição. Um acordo é conseguido através de formas convencionalizadas, pois, qualquer que seja o mecanismo indireto utilizado para fazer um FTA, uma vez totalmente convencionalizado, ele não será mais considerado indireto ${ }^{12}$. O uso desta estratégia demonstra respeito e deferência; evita que o falante incorra em débitos ou visa a minimizá-los; mantém distância social e evita excessiva familiaridade, além de diminuir a tensão através do oferecimento de pretensas rotas de escape.

Considerando a situação de comunicação, as variáveis sociológicas e as vantagens proporcionadas, cabe ao falante selecionar a estratégia mais adequada aos seus objetivos.

\subsubsection{Realizações das Estratégias de Trabalho da Face na linguagem}

As estratégias apresentadas anteriormente como 'super-estratégias' dão origem a estratégias denominadas 'de segunda ordem', as quais, por sua vez, se realizam efetivamente na comunicação através de estratégias de um terceiro nível, que denominamos estratégias formais (output strategies cf. BROWN \& LEVINSON, 1979: 97).

Tais estratégias nem sempre se referem a ações lingüísticas. Por exemplo, entre as estratégias formais de polidez positiva, as quais procuram reforçar os aspectos de apreciação do interlocutor e de sua inclusão em um grupo, encontram-se, entre outras, tanto o elogio de algum aspecto ou propriedade do interlocutor (por exemplo: o cabelo, o carro etc.) ou o uso de

\footnotetext{
${ }^{12}$ Sobre convencionalidade veja, por exemplo, o capítulo 3 de TAGNIN (1989)
} 
gestos de amizade e confiança, como o conhecido "tapinha nas costas". Porém, grande parte das estratégias baseia-se em meios lingüísticos ou em manipulações da interação realizadas lingüisticamente. BROWN \& LEVINSON apresentam uma lista completa e bastante detalhada de diversas possibilidades de realização de cada estratégia, acompanhadas de exemplos extraídos de diferentes culturas, de acordo com sua tese de que tais estratégias são universais.

BROWN \& LEVINSON argumentam que o falante seleciona as estratégias e os meios de expressão lingüística com vistas a atingir o fim desejado, isto é, explicitar a super-estratégia de Trabalho da Face que pretende privilegiar:

[...] a face-bearing rational agent will tend to utilize the FTA-minimizing strategies according to a rational assessment of the face risk to participantes. He would behave thus by virtue of practical means to satisfy stated ends.

We now claim that what links these strategies to their verbal expressions is exactly the same kind of means-ends reasoning. For example, suppose our Model Person has chosen the strategy of negative politeness: recall that negative politeness consists in doing the FTA on record, with redressive action directed to the addressee's perennial want not to be imposed upon. Then our MP must unambiguously express the FTA, and choose between a set of appropriate ways that would partially satisfy that negative-face want of the addressee's; that is: he must do so if he intends to rationally satisfy his desire to achieve the end we have labelled negative politeness. He may choose more than one such means of redressive action, as long as those chosen are consistent, and the effort expended not out of proportion to the face risk attending the FTA. (BROWN \& LEVINSON, 1978: 96).

Em diagramas às páginas 107, 136 e 219 da obra ora citada, os quais reproduzimos mais adiante, os autores resumem os passos seguidos pelo falante para a escolha de meios lingüísticos. Nos diagramas, a superestratégia selecionada pelo falante como um fim aparece à esquerda; ligados a ela estão as estratégias de segunda ordem através das quais (ao menos parcialmente) ele atingiria tal fim, finalmente às estratégias formais que satisfarão (em certa medida) as necessidades conectadas a elas pelas linhas. Pode-se seguir mais de um caminho simultaneamente, desde que eles não sejam incompatíveis. BROWN \& LEVINSON alertam para o fato de que as necessidades indicadas não são as únicas motivações para o uso dos meios lingüísticos, havendo motivações sociais muito gerais para o uso das várias técnicas de polidez positiva e negativa: "elas operam, respectivamente, 
como um tipo de acelerador e freio social para diminuir e aumentar a distância social em relacionamentos, independentemente dos FTAs" (BROWN \& LEVINSON, 1978: 98).

Também não se deve entender que uma forma lingüística apontada nos diagramas seja sempre e unicamente uma expressão de polidez positiva ou negativa. Isto fica bem claro no caso dos hedges. Os autores definem hedges como: "partícula, palavra ou frase que modifica o grau de filiação de um predicado ou sintagma nominal em um conjunto; diz, de sua filiação, que ela é parcial, ou verdadeira apenas em alguns aspectos, ou que é mais verdadeiro ou completo do que seria esperado" (ibid., p. 150). Os hedges podem ser usados na realização tanto de polidez positiva quanto negativa, como até mesmo em situações completamente desvinculadas da polidez, como para limitar responsabilidades criminais (cf. ibid., p. 151). Os meios lingüísticos aqui descritos são comumente utilizados em contextos nos quais têm a função de expressar polidez, mas não são destinados a priori a executar tal função.

Há dois aspectos gerais do uso de meios lingüísticos para funções de Trabalho da Face que parecem válidos para todas as estratégias:

1) a organização e distribuição das expressões selecionadas, provavelmente por razões de topicalização e foco. Assim, expressões de polidez parecem ter tendência a preceder o FTA, sendo, por exemplo, a frase (1) mais polida do que a (2):

(1) Se você não se importa, poderia me dizer quanto custou este lindo vaso?

(2) Poderia me dizer quanto custou este lindo vaso, se você não se importa?

2) quanto maior o esforço do falante com o comportamento lingüístico mantenedor da Face, tanto mais o falante comunica seu desejo sincero de que as necessidades de Face do interlocutor sejam satisfeitas. Tal dispêndio de esforços parece estar intimamente ligado à polidez em muitas culturas. (cf. BROWN \& LEVINSON, 1978: 98-99).

Apresentamos, a seguir, de forma resumida, os meios lingüísticos citados pelos autores como os mais utilizados para a realização das Estratégias de Trabalho da Face: 


\subsubsection{Fazer o FTA diretamente}

Embora tenhamos anteriormente (no item 2.2, através da exposição das idéias de SPERBER \& WILSON) mostrado como as Máximas de GRICE podem ser resumidas ao Princípio da Relevância, manteremos neste capítulo a formulação tradicional das mesmas, seguindo BROWN \& LEVINSON. Não vemos nenhuma incongruência neste procedimento, pois os autores aqui resenhados tratam principalmente de violações de tais regras, que podem perfeitamente serem consideradas como instâncias específicas de manipulação do Princípio de Relevância no que se refere ao conteúdo e à forma dos enunciados em questão.

BROWN \& LEVINSON definem a estratégia de realizar o FTA diretamente como falar em conformidade com as Máximas de GRICE, apresentadas da seguinte maneira:

Máxima da Qualidade: não seja falso (fale a verdade, seja sincero)

Máxima da Quantidade: a) não diga menos que o necessário

b) não diga mais que o necessário

Máxima da Relevância: seja relevante

Máxima de Modo: seja inteligível: evite ambigüidade e obscuridade

(cf. BROWN \& LEVINSON, 1978: 100)

A razão principal para o uso desta estratégia é quando o desejo de efetuar o FTA com a máxima eficiência é maior que a necessidade de satisfazer a Face do interlocutor. Distinguem-se duas classes de uso em diferentes circunstâncias:

1) aquelas na qual a ameaça à Face não é minimizada:

- Em casos de grande urgência ou desespero (ex.: Socorro!, Cuidado! Tire os pés daí!);

- em casos onde o falante se expressa como se eficiência máxima fosse necessária (ex.: Ouça-me! Veja, o caso é o seguinte...);

- em casos de ruído no canal ou dificuldades na comunicação (ex.: conexão telefônica imperfeita, interação com estrangeiros que quase não entendem a língua do falante);

- em casos onde a atividade é o centro da interação (ex.: Passe-me o martelo);

- Em casos nos quais o FTA é primariamente de interesse do interlocutor (ex.: Seu sapato está desamarrado). 
2) aquelas onde o falante minimiza a ameaça à Face por implicação, nas quais é polido que o falante alivie a ansiedade de interlocutor, "convidando-o" preventivamente a invadir a privacidade do falante. Três áreas em que isso ocorre são:

- Recepção (ex.: Entre!)

- Despedida (ex.: Já vou indo.)

- Oferecimento (ex.: Sente-se! Não se importe, eu limpo tudo mais tarde.)

\subsubsection{Estratégias de Compensação baseadas na Polidez Positiva}

A polidez positiva geralmente não é percebida no cotidiano, pois suas realizações lingüísticas são, em muitos aspectos, simplesmente representativas do comportamento lingüístico normal entre pessoas íntimas. BROWN \& LEVINSON afirmam que talvez o único traço que distingue a compensação através de polidez positiva da linguagem íntima normal do dia-a-dia seja um elemento de exagero. $\mathrm{O}$ elemento de insinceridade em expressões exageradas de aprovação ou interesse é compensado pela implicação de que o falante sinceramente deseja que a Face do interlocutor seja valorizada (cf. BROWN \& LEVINSON, 1976: 106-108).

As Estratégias de Compensação Positiva podem ser agrupadas sob três comportamentos básicos que correspondem a estratégias de segunda ordem:

- Alegue pontos em comum:

- Dê a impressão de que interlocutor e falante são colaboradores

- Atenda às necessidades de interlocutor

Cada uma destas sub-estratégias apresenta diversas possibilidades de realização através de estratégias formais. BROWN \& LEVINSON apontam quinze estratégias formais para a Compensação Positiva:

\section{I - Alegue pontos em comum:}

1) Note, atenda ao interlocutor (a seus interesses, necessidades, bens): demonstrar atenção para aspectos da sua condição (ex.: cabelo) ou demonstrar que uma "gafe" do mesmo não embaraçou o falante (ex.: responder "não foi nada" após um pedido de desculpas). 
2) Exagere (interesse, aprovação, simpatia para com o interlocutor): geralmente com entonação e acento exagerados ou outros aspectos prosódicos, bem como através de elementos intensificadores (ex. Seu vestido é SUPER bonito!).

3) Intensifique o interesse pelo interlocutor: apresentando contribuições para "fazer uma boa história"; uso do "presente vívido" e do jogo com presente/passado em narrativas; uso do discurso direto citado, exagero de fatos, tag-questions (ex.: não é?) e expressões que levam o ouvinte a participar da conversa (ex.: sabe? me entende?).

4) Use marcadores de identidade grupal: formas grupais de tratamento, dialeto, jargão, gíria e elipses, nomes genéricos e formas de tratamento (ex.: "tia" para uma mulher mais velha, "doutor" para uma pessoa importante); apelidos, diminutivos e formas carinhosas (ex.: "benzinho").

5) Busque concordância: abordando tópicos seguros (ex. tempo meteorológico); buscar, nos tópicos, aspectos nos quais a concordância é possível e agarrar-se a eles; repetição (total ou parcial) do que foi dito pelo interlocutor.

6) Evite discordâncias: concordância artificial (torcer o enunciado de modo a esconder a discordância por meio de uma concordância aparente (ex.: "sim, mas..."); deslocamento do posicionamento de respostas para suavizar a discordância (ex.: - "Você vem para casa cedo?" - "Bem, eu tenho muito o que fazer. Não sei, eu não vou chegar muito cedo"); ironia, pseudo-concordância (uso de elementos como "então" para sugerir que o que o falante está apresentando é uma conclusão à qual chegou juntamente com o interlocutor - ex.: "Então a gente se encontra às oito horas"); pequenas mentiras inofensivas (white lies); opiniões com hedges (opiniões vagas, relativizadas, frequentemente usadas para suavizar sugestões, críticas ou queixas (ex.: "Você foi meio rude com ele").

7) Pressuponha/crie/declare pontos comuns: falando sobre assuntos não-relacionados ao FTA por algum tempo, como compensação, antes de fazê-lo ("fofoca", small talk); operações no ponto de vista (mudanças no ponto central do enunciado por meio de manipulação da dêixis), técnicas de redução de distância entre os pontos de vista de interlocutor e falante: 
a) mudança do foco pessoal do falante para o interlocutor: o falante se expressa como se fosse o interlocutor ou se ambos tivessem os mesmos conhecimentos ou sentimentos (uso do "nós" inclusivo e de expressões como "você sabe");

b) mudança de tempo ("presente vívido"), de espaço (demonstrativos, verbos de movimento; ex.: "Eu chego já", onde o foco é o ponto onde está o ouvinte);

c) eliminação da necessidade de ajustes de perspectiva para o interlocutor (citações em discurso direto: "Então ele disse: não volte mais aqui...");

d) manipulação de pressuposições: o falante se expressa como se algo fosse mutuamente pressuposto: atitudes e informações do interlocutor (questões negativas que pressupõem "sim" como resposta - ex.: "Você não quer mais um pedaço de bolo?"); familiaridade nas relações entre interlocutor e falante (uso de expressões como "amigo", "camarada" para pessoas desconhecidas).

8) Use gracejos, pois estes pressupõem um background comum aos participantes da interação.

\section{II - Dê a impressão de que interlocutor e falante são colaboradores}

9) Afirme ou pressuponha que o falante conhece e se preocupa com as necessidades do interlocutor (ex.: "Eu sei que você detesta festas, mas esta vai ser ótima! Podemos ir?").

10) Ofereça, prometa, mesmo sem intenção de cumprir (ex.: "A gente se telefona").

11) Seja otimista: pressuponha que o interlocutor quer colaborar (ex.: "Eu sei que você não vai se importar se eu pegar o seu livro"); minimize o FTA com expressões apropriadas (como "um pouco", "um segundo".; ex.: "Você pode vir aqui por um segundo?" minimizando o tempo que a pessoa vai dispender).

12) Inclua falante e interlocutor na atividade ( uso de "nós inclusivo"; ex.: enfermeira para o paciente: "Como estamos nos sentindo hoje?")

13) Dê (ou peça) razões para a atenuação de crítica ou em sugestões indiretas convencionalizadas (ex.: "Por que você não vai ao cinema hoje?")

14) Pressuponha ou declare reciprocidade (ex.: "Você pode me substituir na reunião? Na próxima eu vou em seu lugar"). 
III - Realize as necessidades do interlocutor

15) Dê presentes ao interlocutor (bens, simpatia, compreensão, cooperação).

Na página seguinte, reproduzimos o diagrama de BROWN \& LEVINSON que apresenta as diversas estratégias de polidez positiva e sua hierarquia. 
Estratégias de polidez positiva (BROWN \& LEVINSON, 1978: 107)

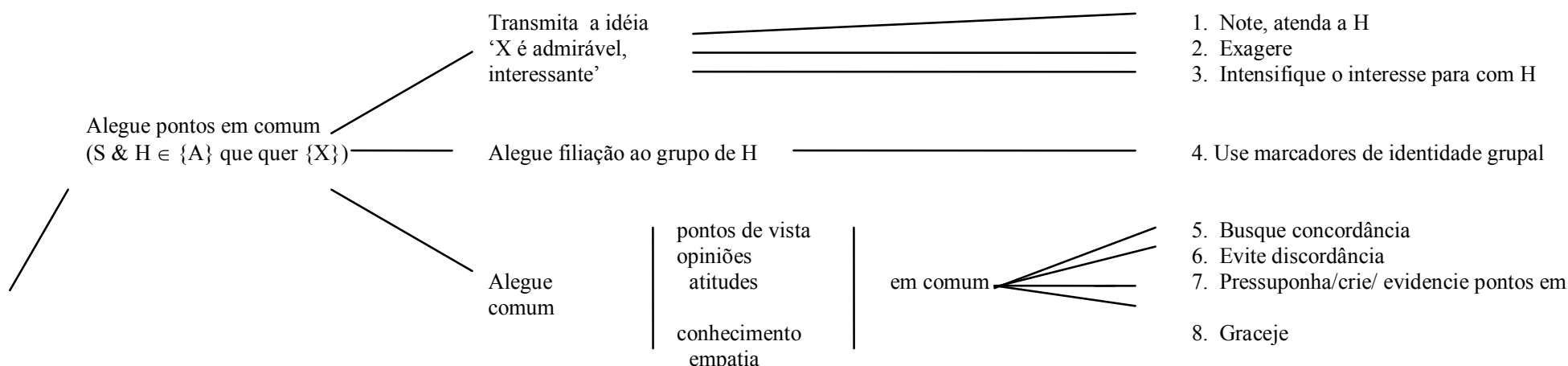

Polidez Positiva

Faça o FTA explicitamente, com ação come o [S quer o que $\mathrm{H}$ quer]
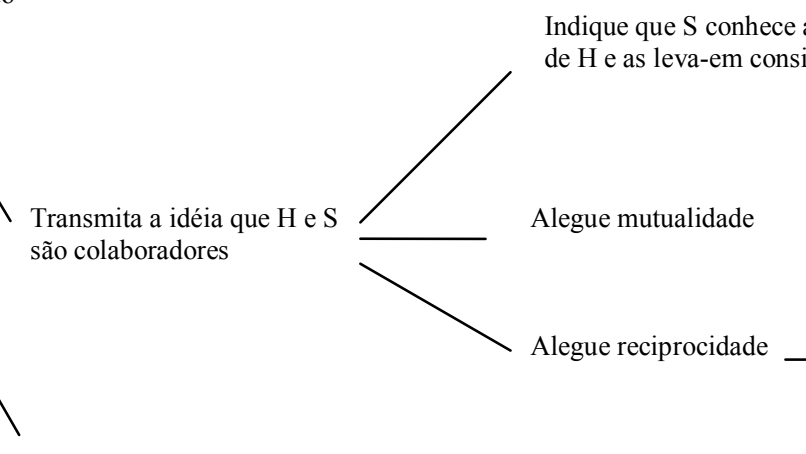

Alegue reciprocidade

9. Afirme ou pressuponha conhecimento e preocupação com as necessidades de $\mathrm{H}$

Se $\mathrm{H}$ quer que $[\mathrm{H}$ tenha $\mathrm{X}]$ então $\mathrm{S}$ quer que $[\mathrm{H}$ tenha $\mathrm{X}$

Se $S$ quer que [S tenha $X]$ então $\mathrm{H}$ quer que $[\mathrm{S}$ tenha $\mathrm{X}]$

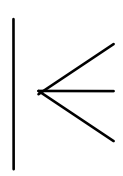

10. Ofereça, prometa

12. Inclua $\mathrm{S}$ e $\mathrm{H}$ na atividade 13. Dê (ou peça por) razões

14. Pressuponha ou afirme reciprocidade 


\subsubsection{Estratégias de Compensação baseadas na Polidez Negativa}

Nas culturas ocidentais, é considerada a forma de cortesia por excelência, o conjunto mais elaborado e mais convencionalizado de estratégias lingüísticas para compensação de FTAs. Realiza-se através de cinco sub-estratégias:

- Seja direto

- Não presuma/pressuponha

- Não coaja o interlocutor

- Comunique a vontade do falante de não impingir-se ao interlocutor

- Recompense outras necessidades do interlocutor

às quais, por sua vez, os autores atribuem dez possibilidades de estratégias formais:

I. Seja direto: Para evitar o choque entre o desejo de ser direto e evitar imposições, utilizam-se estratégias, como:

1) Seja convencionalmente indireto: uso de frases que se tornaram contextualmente inequívocas por convencionalidade (ex.: "Você pode (por favor) me passar o sal?", não é entendido como um pedido de informação, mas sim como um pedido para passar o sal, tanto que é possível inserir-se a expressão "por favor". Um outro exemplo é "Mas por que pintar a casa de lilás?", onde está implícita uma crítica). Pelo uso desta estratégia, o falante comunica o seu desejo de ser indireto, mesmo que, na realidade, o enunciado valha como explícito.

II. Não presuma/pressuponha (mantenha distância ritual do interlocutor)

2) Utilize perguntas, hedges: $O$ uso de hedges ${ }^{13}$ evita $o$ comprometimento e é um meio fundamental e primário de desarmar ameaças interacionais (ex.: "Você talvez possa me ajudar"; "venha cedo, se você puder"). Brown \& Levinson consideram que alguns hedges são endereçados às máximas de GRICE, atuando na qualidade (sugerindo que o falante não assume a responsabilidade total pela veracidade de seu enunciado - ex.: "eu creio...", "parece-me que ..."); na quantidade (a informação fornecida não é tão completa ou precisa

\footnotetext{
${ }^{13}$ Hedges são, a grosso modo, expressões que modificam os pressupostos exigidos para que um conteúdo seja aceitável ou não. O termo é retomado e detalhado posteriormente no item 3.1.2.3.2i.
} 
quanto esperada - ex.: uso de expressões como "mais ou menos", aproximadamente", "tipo..."); na relevância (marcas de mudança de tópico, como "talvez não seja importante, mas..."; "a propósito, ..."); no modo (ex.: "para ser mais preciso...", "resumidamente, ..."). É importante ressaltar que a prosódia e os movimentos do corpo e da face também podem atuar como hedges.

\section{Não coaja o interlocutor}

3) Seja pessimista: expressando dúvidas, através de pedidos indiretos com um operador de negação, do uso do subjuntivo ou de marcadores de possibilidade remota (ex.: "Você não estaria livre na quarta-feira, não é?")

4) Minimize a imposição (através de expressões como: "só vai levar um minuto", "não é nada importante").

5) Preste homenagem: rebaixando o falante (ex.: "Eu não cozinho muito bem, mas dá para comer" implicando que o falante não se considera perfeito), elevando o interlocutor através de termos honoríficos (senhor, V.Exa.) ou mostrando hesitação (ex.: "Eu... hã...preciso... falar com você...". A hesitação mostra que o falante não julga ser importante o bastante para que o interlocutor the dê atenção).

IV-Comunique a vontade do falante de não se impingir ao interlocutor

6) Desculpe-se: admita a intrusão; indique relutância através de hedges e outras expressões; dê razões irresistíveis; peça perdão (ex.: "Sinto muito, eu não queria interromper, mas eu preciso perguntar uma coisa").

7) Impessoalize interlocutor e falante: evite os pronomes "eu" e "você" através de verbos impessoais, voz passiva, pronomes indefinidos, pluralização de pronomes, uso de pronomes de tratamento, distanciamento do ponto de vista (p.ex., uso do passado como em "eu estava pensando se você poderia...", de demonstrativos e do discurso indireto).

8) Apresente o FTA como uma regra geral (ex.: "aqui não é permitido fumar" como um pedido para apagar o cigarro).

9) Nominalize: ex.: "A sua recusa não foi bem aceita", ao invés de "o fato de você ter recusado...". "Intuitivamente, quanto mais uma expressão é nominalizada, tanto mais um agente é afastado do fazer 
ou sentir algo; ao invés de o predicado ser algo atribuído a um agente, este torna-se apenas parte de sua ação. No que se refere ao FTA, a progressiva remoção de um elemento da 'parte atuante' de uma expressão faz com que ele pareça ser menos perigoso (cf. BROWN \& LEVINSON, 1978: 213).

\section{Recompense outras necessidades do interlocutor}

10) Atue explicitamente como incorrendo em um débito, ou não onerando o interlocutor (ex.: "Fico te devendo uma", como agradecimento por um favor prestado, ou "se não der, não precisa", para desobrigar o interlocutor de fazer o que the foi pedido).

A seguir, apresentamos o quadro no qual BROWN \& LEVINSON apresentam as diversas estratégias de polidez negativa e sua hierarquia. 
Estratégias de polidez negativa (BROWN \& LEVINSON, 1978: 136)

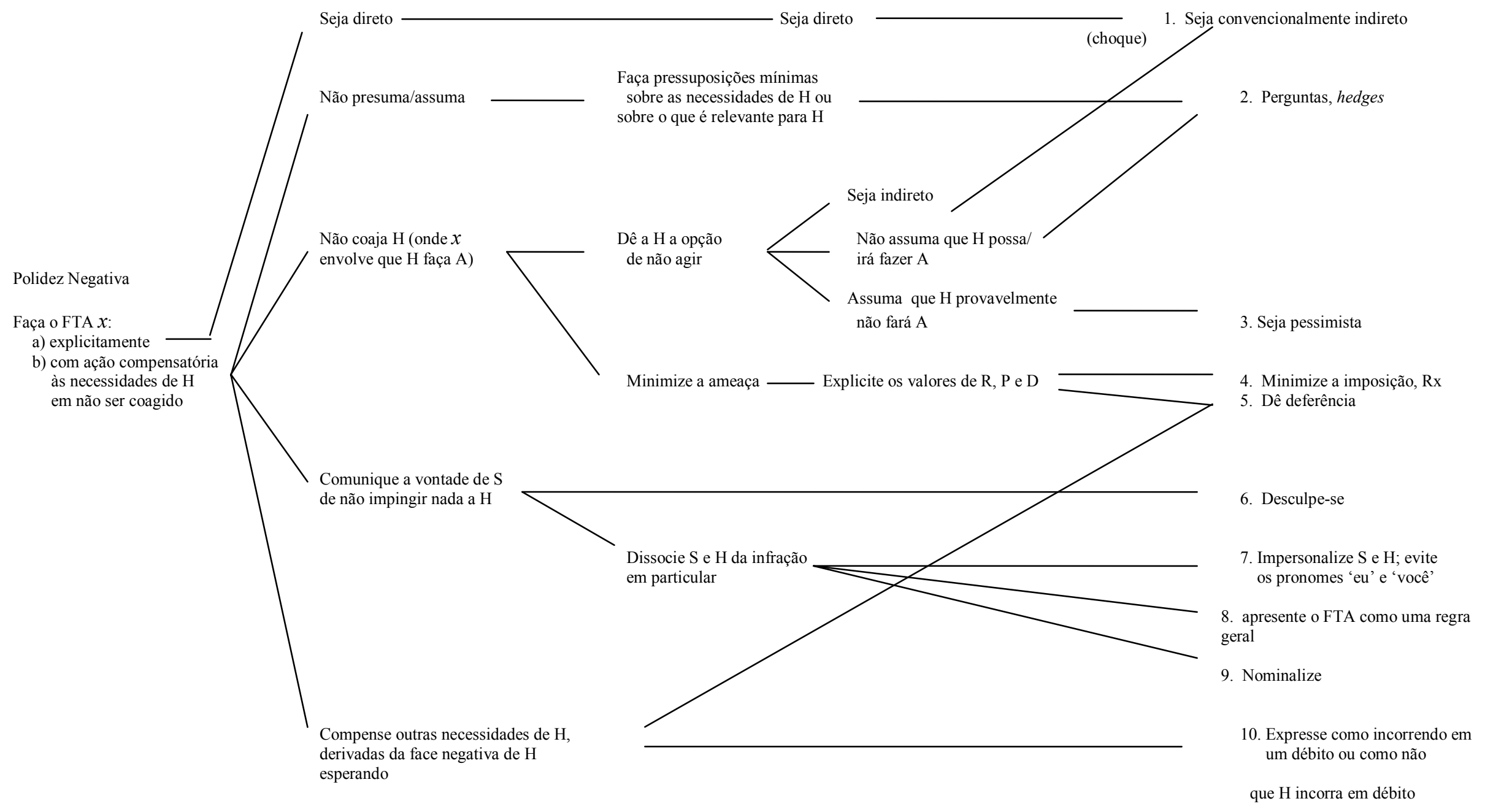




\subsubsection{Fazer o FTA off record}

Esta estratégia consiste essencialmente do uso de implicaturas, dizendo algo que é mais geral ou realmente diferente do que se quer dizer, ou seja, ativando-se "raciocínios Griceanos" (cf. HeRINGER apud BISLEMÜLLER, 1991: 6): o interlocutor precisa fazer inferências para recobrar o que o falante realmente quis dizer. Um trigger (qualquer elemento lingüístico ou comportamento ostensivo que, nos termos de SPERBER \& WILSON, parece ir contra o Princípio de Relevância) alerta o interlocutor de que alguma inferência deve ser feita, partindo-se do que foi realmente dito e dos conhecimentos lógicos e enciclopédicos comuns aos participantes da interação. BROWN \& LEVINSON dividem os procedimentos para a realização desta estratégia em dois grupos:

\section{I - Provoque implicaturas conversacionais:}

\section{a) viole a Máxima da Relevância:}

1) Dê indicações, manipulando a Máxima da Relevância (ex.: "está frio aqui!", dito na esperança de que alguém se ofereça para fechar a janela).

2) Dê pistas para associações: através de eufemismos (ex.: "ir lavar as mãos" ao invés de "ir ao banheiro") ou mencionando algo relacionado com o ato requerido do interlocutor, para que ele complete a associação com base em precedentes (ex.: "Oh, eu estou novamente com aquela dor de cabeça!", significando "dê-me outro daqueles seus comprimidos").

3) Pressuponha: manipulações da relevância a nível das pressuposições (ex.: "Eu lavei a cozinha ontem", pressupondo que o outro sabe que ele teve de fazê-lo, podendo ter implicações de crítica, ou lembrando o interlocutor de que hoje é a sua vez de lavar a cozinha). Pode-se, para tanto, inclusive fazer uso de acento contrastivo, como no exemplo "EU não ando com gente desse tipo!" (pressupondo que alguém anda com gente desse tipo - talvez o interlocutor - e implicando uma crítica). 


\section{b) viole a Máxima da Quantidade}

4) Minimize: através de hedges e pontos na escala dos predicados abaixo do ponto real, do uso de ironia (ex.: "Este livro é bem legal/legalzinho" - implicando que o livro não é bom; "Aquilo foi bastante embaraçoso" = muito embaraçoso).

5) Exagere: uso de exagero, sarcasmo (ex.: "Você nunca me responde!").

6) Use tautologias : por exemplo, como justificativa (ex.: "Guerra é guerra!") ou crítica ("Mulheres/homens são assim mesmo!").

c) viole a Máxima da Qualidade

7) Use contradições (por exemplo, como resposta: "Sim e não").

8) Seja irônico, dizendo o oposto do que se quer dizer, também combinado com hedges (ex.: "Lindo dia, não?", dito em um dia chuvoso).

9) Use metáforas (ex.: "João é mesmo um touro!", i.e. é forte como um touro).

10) Use perguntas retóricas (ex.: "O que eu posso dizer?")

\section{II - Seja vago ou ambíguo (viole a Máxima de Modo)}

\section{1) Seja ambíguo}

12) Seja vago, por exemplo, usando eufemismos (ex.: "Eu vou você sabe onde" = ao banheiro; "Parece que alguém não jogou o lixo fora hoje" - alguém $=$ interlocutor)

13) Super-generalize: cite leis, provérbios (ex.: "Pimenta nos olhos dos outros não arde.")

14) Desloque o interlocutor ( dê "indiretas", na esperança que interlocutor se aperceba de que ele é o alvo real do FTA)

15) Seja incompleto, use elipses (ex.: "Bem, já que você não quer...")

$\mathrm{Na}$ página seguinte, as estratégias off record são apresentadas esquematicamente, segundo BROWN \& LEVINSON. 
Estratégias para o FTA off record ( Figura 10, p. 219)

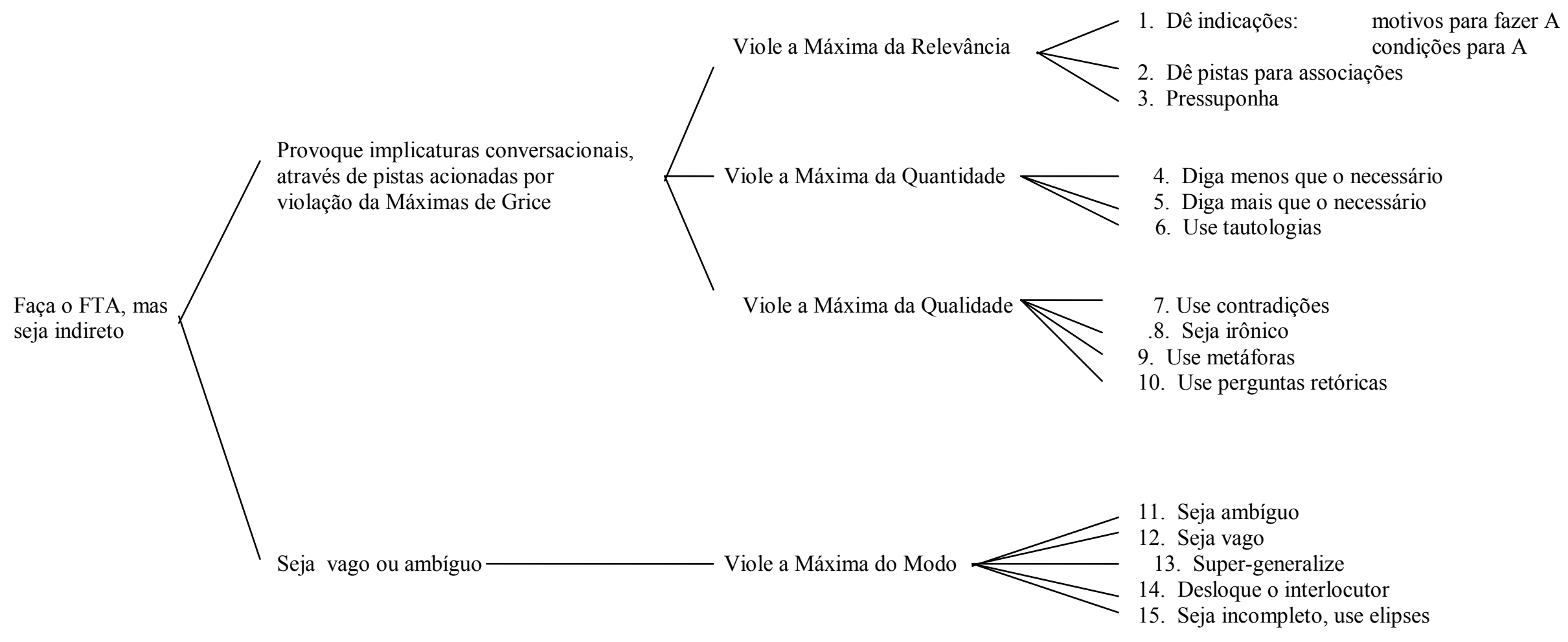


Observando-se o elenco de estratégias formais apresentadas por BROWN \& LEVINSON, nota-se que elas incluem tanto ítens sintáticos (por exemplo, uso do subjuntivo e da voz passiva) como lexicais (verbos modais, partículas, hedges) e suprasegmentais (entonação). Ao examinar os diagramas e os exemplos apontados pelos autores, percebemos que não há, na realidade, elementos que tenham como única função expressar a polidez (com exceção, talvez, da expressão "por favor"), mas sim, que em contextos apropriados, alguns meios lingüísticos (como, por exemplo, o modo subjuntivo, os hedges, a voz passiva, pronomes de tratamento, eufemismos, entre outros) marcam a intenção do falante de aproximar-se ou afastar-se do ouvinte, a fim de preservar a Face deste e a sua própria. Assim, as expressões de polidez só se realizam plenamente em um contexto conversacional, embora algumas expressões já tenham se convencionalizado como "polidas" (como parece ser o caso de perguntas no modo subjuntivo, com ou sem elementos negativos e verbos modais como: "Você (não) me faria o favor...?" e "Você (não) poderia/gostaria de ....?"

\subsection{A Dissensão e o Trabalho da Face}

\subsubsection{A Dissensão como ameaça potencial à Face}

O conceito de Face de GOFFMAn, ampliado por BROWn \& LEVINSON, abriu novas perspectivas para os estudos da interação (veja-se, por exemplo os trabalhos de MATSUMOTO, 1988; WATTS et. al., 1992; YAMASHITA, 1993 e RALL, 1996, entre outros). A necessidade de os participantes respeitarem a própria Face e a de seus parceiros de interação faz com que certas ações se tornem ameaçadoras para pelo menos uma dessas Faces. Entre tais ações, encontra-se a expressão da Dissensão.

Em seu estudo, BROWN \& LEVINSON afirmam que algumas ações ameaçam intrinsecamente as Faces, sendo por eles denominadas de FTAs (Face threatening acts)

Given the assumption of universality of face and rationality, it is intuitively the case that certain kinds of acts intrinsically threaten face, namely those acts that by nature run contrary to the face wants of the addressee and/or of the speaker. Bay 'act' we have in mind what is intended to be done by a verbal or non-verbal communication, just as one or more 'speech-acts' can be assigned to an utterance. (BROWN \& LEVINSON, 1978: 70). 
Os autores fazem distinções entre atos que constituem primariamente ameaças à Face do interlocutor vs. aqueles que são ameaças à Face do falante. Em qualquer um dos casos, o FTA pode dirigir-se à Face negativa ou à positiva do participante em questão. Dentre os FTAs intrínsecos, os autores citam: "aqueles atos que ameaçam as necessidades da Face positiva, indicando (potencialmente) que o falante não liga para os sentimentos, necessidades etc. do interlocutor - que em algum ponto importante, ele não quer o que interlocutor quer [...]" (BROWN \& LEVINSON, 1978: 71). Entre estes atos, incluem-se aqueles que mostram que o falante tem uma avaliação negativa de algum aspecto da Face positiva do interlocutor:

(a) expressões de desaprovação, críticas, desgosto ou ridículo, queixas e reprimendas, insultos (o falante indica que não quer/gosta de uma ou mais necessidades, atos, características pessoais, propriedades, crenças ou valores do interlocutor)

b) contradições ou discordâncias, desafios (o falante indica que ele pensa que o interlocutor está errado ou equivocado ou sendo irracional a respeito de algo, tal erro sendo associado com sua desaprovação)

Segundo esse raciocínio, a desaprovação e a discordância ou, no nosso caso, a Dissensão, constitui um ato de ameaça à Face, com relação ao qual o falante deve, para preservar a harmonia da interação, selecionar cuidadosamente as estratégias a serem utilizadas, formulando suas intervenções do modo mais adequado a atingir seus objetivos, entre os quais, na maioria das vezes, está a preservação da própria Face e da do interlocutor.

\subsubsection{A Dissensão e as Estratégias de Trabalho da Face}

Sendo a Dissensão um FTA intrínseco e, como já citado nos estudos de SORNIG e KOHNEN, potencialmente desestabilizador da interação, sua expressão não pode prescindir de um uso consciente das diversas possibilidades lingüísticas e estratégias de Trabalho da Face a fim de minimizá-la e, assim, preservar as Faces dos participantes de seus efeitos destrutivos. Nossa pesquisa tem por objetivos examinar empiricamente ocorrências de expressão da Dissensão e examiná-las sob os aspectos do Trabalho da Face. 
BROWN \& LEVINSON denominam suas estratégias de "estratégias de polidez". Porém, como já mencionamos anteriormente, consideramos que tal termo tem a desvantagem de confundir-se com aquilo que é normalmente considerado "polidez" na cultura ocidental, ou seja, um conjunto de regras e expressões baseado principalmente na polidez negativa. O termo "estratégias de polidez" não nos parece explicitar satisfatoriamente o objetivo do uso de tais estratégias por um indivíduo participante de uma interação, ou seja, preservar a imagem e a boa relação entre todos os participantes da interação, atentando para suas necessidades sociais e individuais, agrupadas por BROWN \& LEVINSON sob os termos de Face positiva e negativa. Assim, o termo "polidez" parece dirigir-se apenas à Face do interlocutor, perdendo-se a dimensão de proteção da Face do próprio falante e das possibilidades de uso agressivo do Trabalho da Face. Desse modo, preferimos utilizar neste trabalho o termo Estratégias de Trabalho da Face para os comportamentos descritos por BROWN \& LEVINSON que são selecionados pelo falante para proteger sua própria imagem e a dos demais participantes durante uma interação.

Portanto, investigamos nesta pesquisa a expressão da Dissensão no que se refere ao uso das Estratégias de Trabalho da Face e das suas diversas realizações lingüísticas. No capítulo seguinte, detalhamos os critérios para a definição do corpus e os pressupostos metodológicos da pesquisa. 


\section{CAPÍTULO II - MATERIAL E MÉTODO}

\subsection{Corpus}

Como um dos constituintes básicos da Dissensão é a presença de um interlocutor, foram excluídos textos monológicos. Nosso interesse pela língua falada também nos fez descartar textos dialógicos escritos, como troca de correspondência. Tais ponderações dificultaram a escolha do corpus, pois a falta de recursos inviabilizava a coleta e transcrição de textos falados alemães. Tratava-se, então, de obter um corpus em alemão compatível com nossas necessidades, já transcrito e publicado, ao qual tivéssemos acesso. Nossa escolha recaiu, portanto, sobre os volumes da coleção Heutiges Deutsch - Texte deutscher gesprochener Standardsprache (Alemão atual - Textos de língua alemã padrão falada - STEGER et al., 1974 e 1978), os quais contêm inquéritos selecionados do Freiburger Corpus, um projeto para o estudo da língua falada realizado na cidade de Freiburg, na Alemanha.

No que se refere a textos dialógicos, MARCUSCHI apresenta cinco características básicas constitutivas de um diálogo:
a) interação de pelo menos dois falantes;
b) ocorrência de pelo menos uma troca de falantes;
c) presença de uma seqüência de ações coordenadas;
d) execução numa identidade temporal;
e) envolvimento numa "interação centrada"

(MARCUSCHI, 1986: 15)

Mais adiante, MARCUSCHI baseia-se em STEGER para definir dois tipos de diálogos:

1) diálogos assimétricos: em que um dos participantes tem o direito de iniciar, orientar, dirigir e concluir a interação e exercer pressão sobre $\mathrm{o}(\mathrm{s})$ outro(s) participante(s);

2) diálogos simétricos: em que os vários participantes têm supostamente o mesmo direito à auto-escolha da palavra, do tema a tratar e de decidir sobre seu tempo;

salientando, ainda, o fato de a simetria de papéis e direitos nos diálogos simétricos ser sempre afetada pelas diferenças sócio-econômicas, culturais 
ou de poder dos participantes da interação, inexistindo, portanto, uma simetria absoluta (cf. STEGER apud MARCUSCHI, 1986: 16).

Dentre os tipos de inquérito apresentados pelos corpora, decidimonos pelos diálogos simétricos, por serem, ao nosso ver, a forma de comunicação lingüística oral estatisticamente mais utilizada e com menor grau de formalidade.

Os inquéritos constantes do Freiburger Corpus apresentam exemplos de produção lingüística oral de falantes nativos cultos, compilados na Alemanha durante a década de 70, classificados da seguinte maneira:

Conversação (Unterhaltung) Preleção (Vortrag)

Reportagem (Reportage) Narrativa (Erzählung)

Discussão (Diskussion) Entrevista (Interview)

Tais tipos de inquéritos foram definidos com base em elementos extralingüísticos da comunicação, como:

- número de falantes;

- igualdade de direito à tomada de turno;

- unidade de tema.

Com exceção do tipo "conversação", em todos os demais casos os falantes atêm-se a um tema pré-determinado.

\subsubsection{Definição do corpus da pesquisa}

Com base em tais características, selecionamos os inquéritos que se enquadrassem em nossas expectativas para o presente estudo: os inquéritos deveriam ser dialógicos e permitir o surgimento e a expressão de Dissensões entre os participantes devido aos temas abordados e a uma relativa simetria social entre os participantes.

Com relação ao Freiburger Corpus, em razão de nosso interesse por diálogos, apenas os tipos dialógicos "conversação", "discussão" e "entrevista" poderiam ser utilizados. Por ser um gênero de diálogo assimétrico, o tipo "entrevista" também foi descartado, restando como opções os tipos "conversação" e "discussão".

Os diálogos do tipo "conversação" são diálogos gravados no âmbito privado, com número variado de participantes com características sociais diversas e sem preparação prévia ou determinação de um tema central.

Os diálogos caracterizados como "discussão", por sua vez, são diálogos entre vários participantes, gravados principalmente a partir de 
programas de rádio ou de televisão, com um tema central pré-determinado e geralmente têm a presença de um moderador. Os participantes são especialistas no assunto ou pessoas que têm um grande envolvimento com o tema central e que normalmente estão acostumados a debates e discussões, fazendo com que os participantes, à exceção do moderador, tenham, durante a discussão, uma certa igualdade em seu status dentro da interação. Pode-se esperar que, como o próprio nome indica, surjam divergências nas opiniões dos participantes que os levem a um debate sobre aspectos diversos do tema central.

\subsubsection{O gênero "Discussão"}

Na linguagem cotidiana, o termo "discussão" é empregado de um modo muito amplo. O Novo dicionário Aurélio da língua portuguesa traz as seguintes definições para os termos "discussão" e "discutir":

Discussão: 1. Ação de discutir; debate, controvérsia, polêmica

2. Altercação, contenda, disputa

Discutir: 1. Debater (questão, problema, assunto)

2. Examinar, investigar, questionando

3. Pôr em debate, em discussão, contestar

4. Defender ou impugnar (assunto controvertido), questionar

5. Travar discussão, questionar

6. Tomar parte em discussão

7. Questionar, contender

(cf. AURÉLIO, 1986: 596)

As definições apresentadas são bastante imprecisas, principalmente no que se refere ao item 6 de "discutir" - "tomar parte em discussão", sendo que "discussão" é definida como a "ação de discutir". Como o AURÉLIO não é um dicionário especializado em lingüística, tais definições não são adequadas a um estudo científico. Em uma obra científica, como o Tratado da argumentação: A Nova Retórica (PERELMAN, 1996), a discussão é caracterizada como uma interação na qual os interlocutores buscam honestamente e sem preconceitos a melhor solução de um problema controvertido (cf. Perelman, 1996: 41-44). Nota-se que tanto as definições do AURÉlio como de Perelman apresentam os traços de "controvérsia" e "questionamento", apontando para a divergência de opiniões, ou seja, para a Dissensão. 
Ainda no que se refere à "discussão", é interessante notar que o AURÉLIO apresenta duas definições: a primeira, mais neutra, aponta apenas para uma divergência de opiniões; a segunda, "altercação, contenda, disputa", traz uma certa conotação negativa. A nosso ver, este traço negativo está fortemente presente no emprego cotidiano do termo "discussão", sendo provavelmente o primeiro significado sugerido a um brasileiro quando apresentado fora de um contexto específico, como na frase "eles tiveram uma discussão". Isto estaria em conformidade com as considerações apresentadas na Introdução deste estudo, segundo as quais brasileiros tenderiam a evitar confrontos de opiniões divergentes.

$\mathrm{Na}$ Alemanha, porém, embora os dicionários registrem também tanto o aspecto "positivo" como o "negativo" do termo Diskussion, o emprego cotidiano da palavra parece remeter mais diretamente ao significado "neutro" de debate, sendo os termos Streit ou Meinungsverschiedenheit os mais utilizados para o aspecto conflituoso. O DUDEN - Deutsches Universalwörterbuch, principal dicionário da língua alemã, traz as seguintes definições para o termo Diskussion:

Diskussion: 1. a) conversação [que transcorre sob a direção de um moderador e segundo regras formais definidas], intercâmbio de opiniões de várias pessoas sobre um determinado tema;

b) debate entre indivíduos a respeito de determinadas questões, que lhes dizem respeito;

2. Nos meios públicos de comunicação (imprensa, televisão, junto à população etc.), explanação de determinadas questões referentes à comunidade ou a grupos específicos. ${ }^{14}$

(DUDEN, 1983: 277)

O sentido positivo do termo Diskussion em alemão é mencionado e explicado por Holly et al. (1986). Os autores constatam que a discussão é um conceito básico no âmbito da política: nos sistemas democráticos, a discussão é considerada o procedimento par excellence para a formação de opiniões em diversos domínios da política. E também em situações cotidianas, as discussões são vistas como imprescindíveis para a solução solidária (Holly et al., 1986: 4) das mais diversas tarefas e conflitos.

\footnotetext{
14 1.a) [unter der Führung eines Diskussionsleiters stattfindendes, in bestimmter Formablaufendes] Gespräch, Aussprache, Austausch von Meinungen mehrerer Personen über ein bestimmtes Thema; b) Auseinandersetzung zwischen einzelnen Personen über bestimmte, sie angehende Fragen; 2. in der Öffentlichkeit (in der Presse, im Fernsehen, in der Bevölkerung o. ä.) stattfindende Erörterung von bestimmten, die Allgemeinheit od. bestimmte Gruppen betreffenden Fragen. (DUDEN, 1983: 277)
} 
Segundo os autores citados acima, a importância dada à discussão tem suas raízes na longa tradição de discussões nos moldes aristotélicos (Disputationen), comum nas universidades européias durante a Idade Média, estendendo-se até o Barroco. Modernamente, a discussão tem sido considerada como fortemente ligada à forma de governo parlamentarista, integrando atualmente o conteúdo de ensino das escolas secundárias alemãs (cf. ibid, p.10-11). Autores didáticos inclusive sugerem procedimentos para o treinamento de discussões durante as aulas, enfatizando a importância da argumentação objetiva, da fundamentação das considerações apresentadas e a necessidade de enfocar os diversos ângulos da questão (cf ibid, p. 21-22) e instituições governamentais promovem estudos sobre a importância da discussão no âmbito político (como, por exemplo, em SARCINELLI, 1990).

As definições constantes do DUDEN também não são suficientemente precisas para caracterizar a discussão em termos de interação lingüística específica. $O$ mesmo acontece com as definições encontradas em outros dicionários alemães, conforme observam HOLLY et. al., apontando como primeira deficiência o fato de tais definições não contemplarem a existência de dois tipos distintos de discussão: a) como texto monológico e científico (p.ex.: discussão da literatura em uma tese) e b) como processo complexo, principalmente quando público, que se compõe de várias opiniões sobre um tema, expressas de modo alternado pelos participantes do processo (cf. HoLly et al., 1986: 5-6).

De acordo com o objetivo final da discussão e com os procedimentos adotados para a sua resolução, os autores propõem quatro definições para "discussão" no sentido de interação lingüística do termo:

1) Gênero de conversação, no qual fala-se sobre um tema (ou vários) da maneira mais racional e argumentativa, mas também persuasivamente, com a finalidade de formar opinião sobre ele; é a) informal, em conversações cotidianas; b) formal, com um padrão mais ou menos consagrado, eventualmente com um moderador, em parte também (principalmente em rádio e televisão) segundo regras institucionalizadas.

2) Gênero de conversação, no qual se atua de forma argumentativa, mas principalmente persuasiva, como preparação para a) decisões, b) resoluções a respeito de a) sugestões, b) petições; a) informal, em conversações cotidianas; b) formal, eventualmente seguindo uma pauta, em grêmios deliberativos, porém visando a um consenso ou deliberação;

3) Gênero de conversação, no qual se atua de forma argumentativa, persuasiva ou tática, visando a resolução ou impedimento de conflitos sobre problemas comuns; a) em bases de confiança mútua; b) (negativamente) como altercação; 
4) Gênero de conversação, no qual se atua de forma predominantemente persuasiva e tática, com a finalidade de ajustar interesses conflitantes a respeito de reivindicações e desejos. (HoLly et. al., 1986: 7 ss.) ${ }^{15}$

No volume 2 da série Heutiges Deutsch, STEGer et. al. (1974) definem os inquéritos que denominam "discussões" em conformidade com os critérios básicos de número de participantes, direito à palavra e unidade de tema. Desse modo, denominam-se "discussões" as interações lingüísticas que contam com a presença de mais de um participante, os quais, alternadamente e com igual direito à palavra (à exceção do moderador), ocupam-se de um determinado tema, de forma argumentativa, com o objetivo de chegarem a um consenso sobre opiniões ou fatos (STEGER et. al., 1974: 18). Portanto, nota-se que as discussões constantes do Freiburger Corpus correspondem à definição de número 1b) em HOLLY et al., a qual consideramos a mais completa e que adotamos para definir a "discussão" no presente estudo: uma interação dialógica, na qual são utilizados meios argumentativos e/ou persuasivos, com a finalidade de chegar-se a um consenso sobre um tema, através de uma forma de interação com regras formais definidas, eventualmente com a presença de um moderador.

\subsubsection{A Dissensão em Discussões}

Conforme detalhado acima, discussões têm uma forma institucionalizada específica, na qual é garantido aos participantes o direito de apresentarem opiniões divergentes e defendê-las. De acordo com os estudos de Pomeranz (1984) e KotThoff (1989, 1993), tal forma influi diretamente no modo de expressão da Dissensão.

POMERANZ parte do conceito de "preferência" da Análise da Conversação: segundo este conceito, há freqüentemente eventos

\footnotetext{
15 1) Gesprächssorte, in der möglichst rational, argumentativ, aber auch persuasiv zum Zweck der Meinungsbildung über ein Thema (oder mehrere) gesprochen wird; a) informell in Alltagsgesprächen; b) formell: in mehr oder weniger festgelegter Form, evtl. mit einem Diskussionsleiter, z.T. auch (besonders in Rundfunk und Fernsehen) nach bestimmten institutionellen Spielregeln;

2) Gesprächssorte, in der argumentativ, aber vor allem persuasiv zur Vorbereitung von a) Entscheidungen, b) Beschlüssen über a) Vorschläge, b) Anträge gesprochen wird; a) informell in Alltagsgesprächen; b) formell, evtl. nach einer Geschäftsordnung, in beschlußfassenden Gremien, aber entweder im Hinblick auf Konsensbildung oder Abstimmung;

3) Gesprächssorte, in der informativ, persuasiv und taktisch zur Aufarbeitung bzw. Verhinderung von Konflikten über gemeinsame Probleme gesprochen wird; a) auf Vertrauenbasis, b) (neg. bew.) im Streit; 4) Gesprächssorte, in der überwiegend persuasiv und taktisch zum Ausgleich von auseinandergehende Interessen über Ansprüche und Wünsche gesprochen wird.
} 
conversacionais nos quais possibilidades de ação alternativas, mas não equivalentes, estão abertas aos participantes. Em tais casos, certos cursos de ação (courses of action) são rotineiramente selecionados em concordância com o contexto geral e/ou com elementos lingüísticos da interação. Certos contextos evocam ações específicas e preferidas, sendo que sua ausência é considerada relevante, levando a inferências. Em seu estudo de 1984, POMERANZ mostra que a concordância é a alternativa de resposta preferida face a uma afirmação, em um contexto inespecífico. Ressalta, porém, que há contextos específicos nos quais a discordância é a ação de resposta preferida, como, por exemplo, nos casos em que o falante se auto-deprecia. A autora, analisando casos de concordância e discordância em diversos contextos, conclui que as ações não-preferidas (dispreferred) apresentam traços típicos de formas marcadas, sendo freqüentemente prefaciadas, abrandadas e retardadas.

KotThoff, em seu artigo de 1989, retoma o estudo de POMERANZ e propõe que a preferência ou não pela concordância em um determinado contexto é determinada cultural e institucionalmente. Como exemplos, cita a situação de julgamento, na qual o réu deve discordar da sua acusação, e a situação de "desafios" verbais considerados como eventos sociais em certas comunidades (cf. KotTHOFF, 1989: 195-196). Analisando contextos de disputas com falantes americanos e alemães, a autora chega à conclusão de que, em tais contextos, a preferência é pela não-concordância frente a uma afirmação, levando à forte diminuição dos traços de hesitação e abrandamento. Tal conclusão é o ponto de partida para seu estudo de 1993, no qual analisa contrastivamente o estilo de argumentação em disputas com falantes alemães e americanos, chegando à conclusão de que, enquanto os alemães dão maior importância ao conteúdo da discussão, os americanos preocupam-se mais com a relação entre os participantes, procurando um tom mais amistoso. É interessante notar como suas observações sobre os alemães, quando comparados aos americanos, nos remetem ao artigo do jornalista americano citado na Introdução deste estudo, com relação aos americanos e aos brasileiros:

Atribui-se aos alemães no exterior um modo irrestrito de expressão notadamente direto, ao defenderem suas posições com relação a um conteúdo. Nossa insistência em nossas opiniões e nossa prontidão inabalável para ataques verbais são freqüentemente, para nós, sinais de grande envolvimento, mas não nos fazem especialmente queridos no exterior. Isto vale também para os EUA - 
uma cultura com relação à qual nós não supomos haver grandes diferenças estilísticas nas interações (KOTTHOFF, 1989: 197). ${ }^{16}$

Embora tais conclusões venham reforçar a nossa hipótese de que há divergências culturais no modo de expressão da Dissensão entre falantes brasileiros e alemães, isto não será ainda verificado no presente trabalho. $\mathrm{O}$ importante é a constatação de KOTTHOFF de que, em situações de discussão, a discordância frente a uma afirmação é a ação preferida, o que deve contribuir para a livre expressão da Dissensão por parte dos falantes envolvidos, aumentando o número de ocorrências pertinentes à nossa análise. Ainda com referência às conclusões das autoras citadas, deve-se esperar, com relação ao Trabalho da Face, uma diminuição dos elementos de abrandamento e o maior uso de Estratégias de Trabalho da Face diretas.

\subsubsection{Descrição do corpus da pesquisa}

Do ponto de vista dos objetivos de nosso estudo, ou seja, analisar ocorrências de Dissensão, os diálogos do tipo "discussão" apresentam-se, portanto, como mais pertinentes à análise, por favorecerem o surgimento e a expressão de Dissensão por parte dos interlocutores, já que todos os participantes sabem que o objetivo da interação é confrontar diversas opiniões e que a discordância é a ação preferida. Desse modo, a ameaça às Faces é diminuída, o que permite que a expressão da Dissensão não seja inteiramente evitada por receio de prejudicar o relacionamento entre os participantes. Por outro lado, deve-se ter em vista que os resultados obtidos dificilmente poderão ser generalizados para interações espontâneas e não institucionalizadas, e que os participantes estão sempre conscientes da existência de uma audiência, pois as discussões estão sendo transmitidas por meios eletrônicos de comunicação (rádio e/ou televisão), o que também influencia suas estratégias de comportamento durante a interação e, conseqüentemente, sua forma de expressão lingüística.

Mesmo com tais ressalvas, os inquéritos do tipo "discussão" são os mais apropriados ao nosso estudo. Assim, o corpus desta pesquisa será formado por inquéritos do tipo "discussão", cujas transcrições constam dos

\footnotetext{
${ }^{16}$ Deutschen wird im Ausland eine besonders uneingeschränkte Direktheit im Verfolgen von inhaltlichen Positionen nachgesagt. Unser Beharren auf unseren Ansichten und unsere unerschrockene verbale Angriffsbereitschaft gelten uns selbst oft als Zeichen starker Involviertheit, machen uns aber im Ausland nicht unbedingt beliebt. Dies gilt auch für die USA - eine Kultur, zu der wir große Stilldifferenz gar nicht vermuten. (KоTTHOFF, 1989: 197)
} 
volumes 1 e 2 da série Texte gesprochener deutscher Standardsprache, perfazendo um total de 12 inquéritos ou, aproximadamente, sete horas e meia de gravação, assim distribuídas:

\begin{tabular}{|c|c|c|}
\hline Inquérito & Tema & Duraçã \\
\hline \multicolumn{3}{|l|}{ Volume 1} \\
\hline xar & Aktuelle politische Fragen nach Bildung der großen & \\
\hline & $\begin{array}{l}\text { Koalition (Questões políticas atuais após a formação } \\
\text { da grande coalizão) }\end{array}$ & $36^{\prime} 17^{\prime \prime}$ \\
\hline xas & Landwirtschaft in der DDR (Economia rural na RDA) & $28^{\prime} 06^{\prime \prime}$ \\
\hline \multicolumn{3}{|l|}{ Volume 2} \\
\hline $\mathrm{xcg}$ & $\begin{array}{l}\text { Meinung gegen Meinung. Fragen der Verkehrssicherheit } \\
\text { (Opinião contra opinião: Questões da segurança no trânsito }\end{array}$ & $\begin{array}{l}95^{\prime} 40^{\prime \prime} \\
\text { o) }\end{array}$ \\
\hline $\mathrm{xcn}$ & $\begin{array}{l}\text { Sind Geisteskranke Stiefkinder unserer Gesellschaft? } \\
\text { (Os doentes mentais são enjeitados em nossa sociedade?) }\end{array}$ & $36^{\prime} 40^{\prime \prime}$ \\
\hline xey & $\begin{array}{l}\text { Schwierige Mütter - schwierige Töchter } \\
\text { (Mães complicadas - filhas complicadas) }\end{array}$ & $31^{\prime} 50^{\prime \prime}$ \\
\hline $\mathrm{xbv}$ & $\begin{array}{l}\text { Die fixe Idee: Kann man Bouletten wirklich essen? } \\
\text { (A idéia fixa: Pode-se realmente comer almôndegas?) }\end{array}$ & $29^{\prime} 34^{\prime \prime}$ \\
\hline \multirow[t]{2}{*}{ yas } & $\begin{array}{l}\text { Ist der Nannen-Mitarbeiter Weidemann ein } \\
\text { Kriegsverbrecher? (Weidemann, colaborador }\end{array}$ & ox.) $30^{\prime}$ \\
\hline & de Nannen, é um criminoso de guerra? (duração não in & ndicada) \\
\hline yay & Nach-Ulbricht-Ära (A era pós-Ulbricht) & $24^{\prime} 45^{\prime \prime}$ \\
\hline $\mathrm{ybb}$ & $\begin{array}{l}\text { Kulturpolitik im Ausland - aber wie? } \\
\text { (Política cultural no exterior - mas como?) }\end{array}$ & $25^{\prime} 10^{\prime \prime}$ \\
\hline ybc & Sex vor der Ehe (Sexo antes do casamento) & $29^{\prime} 45^{\prime \prime}$ \\
\hline $\mathrm{xdf}$ & Deutschstunde - Aber wie? (Aula de alemão - mas como?) & $42^{\prime} 10^{\prime \prime}$ \\
\hline$x d x$ & $\begin{array}{l}\text { Moral 71. Zum Beispiel Abtreibung } \\
\text { (Moral 71. Por exemplo: aborto) }\end{array}$ & $37^{\prime} 30^{\prime \prime}$ \\
\hline yaw & Magazin-Moderatoren (Moderadores de mesas-redondas) & $10^{\prime} 50^{\prime \prime}$ \\
\hline
\end{tabular}

Os inquéritos selecionados são extratos de programas alemães de rádio ou televisão dedicados à discussão de temas diversos, desde política e economia até questões morais e culinárias. Os inquéritos têm um número de participantes variando entre um mínimo de três e um máximo de nove, incluindo informantes de ambos os sexos e de idades variáveis. A diversidade de temas e informantes, bem como a duração dos inquéritos do corpus, contribui, certamente, para uma grande diversidade de exemplos de expressão da Dissensão e da utilização de Estratégias de Trabalho da Face, evitando, assim, que os resultados da pesquisa sejam influenciados pelo estilo pessoal de determinados interlocutores. 
A fim de facilitar a identificação dos inquéritos com referência a seus temas, não utilizaremos neste estudo a notação constante da publicação Heutiges Deutsch. Assim, os inquéritos acima descritos serão identificados doravante pelas seguintes denominações:

\begin{tabular}{|ccc|}
\hline$\frac{\text { Inquérito: }}{\text { denominação }}$ & $\begin{array}{c}\text { Nossa } \\
\text { original }\end{array}$ & Nossa sigla \\
Volume 1 & & \\
xar & & \\
xas & COALIZão & COA \\
& RDA & RDA \\
Volume 2 & & \\
xcg & TRÂNSITO & TRA \\
xcn & MENTAL & MEN \\
xey & MÃES & MAE \\
xbv & ALMÔNDEGAS & ALM \\
yas & GUERRA & GUE \\
yay & ULBRICHT & ULB \\
ybb & EXTERIOR & EXT \\
ybc & SEXO & SEX \\
xdf & ALEMÃO & ALE \\
xdx & ABORTO & ABO \\
yaw & MODERADORES & MOD \\
& & \\
\hline
\end{tabular}

\subsubsection{Caracterização dos inquéritos}

De maneira a permitir um melhor entendimento das relações sociais e do desenvolvimento da interação, fazemos, a seguir, uma breve descrição de cada um dos inquéritos utilizados para o corpus da pesquisa.

$\mathrm{O}$ inquérito COALIZÃo tem por tema uma recente (à epoca) mudança no equilíbrio de forças no parlamento alemão, com o fim de uma grande coalizão e o início do governo Kiesinger-Brandt. Entre os oito participantes desta discussão da televisão alemã, todos do sexo masculino, estão jornalistas e eminentes políticos alemães, como Helmut Schmidt, FranzJosef Strauß. Os participantes debatem as razões da queda da coalizão, o sistema político da RFA e questões referentes à atuação dos políticos presentes. A discussão, na maior parte do tempo amigável, vai-se acirrando em direção ao final, quando alguns participantes começam a questionar comportamentos de alguns membros do parlamento alemão. 
O inquérito denominado RDA é o único exemplar de uma discussão em um programa da antiga República Democrática Alemã. Participam desta discussão o moderador, que também é presidente do comitê nacional de telecomunicações, dois outros participantes com o título de doutor (embora não fique claro em que especialidade) e uma única mulher, líder de um grupo responsável pela criação de gado. O tema é o sucesso da política agrícola vigente na época e a comparação com a política da República Federal Alemã. É interessante notar que, embora o assunto da discussão seja a política agrária, o fato de que o programa era também recebido na RFA dá ensejo a um grande número de críticas ao sistema político deste país, em contraposição à eficiência e bem estar da RDA. A discussão transcorre sem qualquer conflito, com grande participação do moderador, que emite várias opiniões e faz perguntas aos participantes, orientando seu raciocínio e apontando os temas a serem tratados.

$\mathrm{O}$ inquérito que recebe a denominação TRÂNSITO é uma discussão entre cinco participantes, todos homens, que discutem problemas relativos à segurança no trânsito na RFA. Entre os participantes estão um moderador, um deputado federal, um jurista do Automóvel Clube da Alemanha (ADAC), o redator-chefe de uma revista especializada em veículos e um motorista de caminhão. Cinco ouvintes fazem perguntas e dão sugestões por telefone, sendo-lhes inclusive possível participar da discussão diretamente. Os principais tópicos discutidos são o limite de velocidade e o serviço de resgate a acidentados.

Sob a denominação MENTAL, temos uma discussão televisiva sobre o tratamento dado aos doentes mentais na RFA. Os pontos mais enfatizados são: a construção de clínicas psiquiátricas, a relação entre os doentes e a sociedade e as dificuldades referentes à obtenção de pessoal e meios financeiros para o trabalho nas instituições. Entre os quatro participantes, todos homens, estão, além do moderador, o diretor do Hospital Universitário para doenças nervosas da cidade de Tübingen, o presidente da comissão federal de representantes dos hospitais psiquiátricos e o autor de um livro sobre problemas das instituições psiquiátricas na RFA.

No inquérito intitulado MÃES, as nove participantes, mulheres, discutem os problemas de relacionamento entre mães e filhas. A discussão, aqui, é mais dirigida, pois que a moderadora atua com muita persistência, redirecionando freqüentemente a discussão, distribuindo a palavra, e participando ativamente. Duas participantes são mãe e filha e outra tem o título de doutor, embora não fique clara sua especialidade. Os principais 
assuntos discutidos são: fuga dos filhos da casa dos pais, educação para a auto-suficiência, questões do esclarecimento sexual, a vida em uma comunidade alternativa, emancipação feminina e os planos das filhas para o futuro.

$\mathrm{O}$ inquérito ALMÔNDEGAS tem como participantes cinco homens e uma mulher. Esta discussão tem a peculiaridade de provir de um programa no qual se organizam discussões sobre temas absurdos, os quais são debatidos com toda a pretensão de seriedade e de acordo com as regras do gênero. Os participantes são informados do tema pouco antes do início do programa, o que torna suas contribuições mais espontâneas. $\mathrm{O}$ tema deste inquérito é a possibilidade ou não de se comer almôndegas. Na tentativa de impor sua opinião, os participantes levantam as mais absurdas hipóteses, entre elas, as de que "almôndegas são um tipo de animais caseiros que fazem ninhos na geladeira" ou de que "almôndegas eram originalmente ornamentos feitos de carne petrificada, os quais foram posteriormente transformados em armas e em equipamentos para esporte". A discussão é bastante interessante e bem humorada.

Ao contrário do anterior, o inquérito GUERRA nada tem de bemhumorado. Esta discussão sobre o passado de Henri Nannen, colaborador da revista Stern, acabou degenerando em uma discussão no sentido negativo da palavra, ou seja, em um "bate-boca" (Streit). Além do próprio Nannen, participam da discussão dois moderadores da emissora de televisão ZDF. Um destes últimos havia feito, em programas anteriores, acusações de envolvimento de Nannen em crimes de guerra, o qual solicitou ao programa esta nova entrevista, para discutir o assunto. A discussão inicia-se já em um clima bastante hostil, que aumenta cada vez mais com o decorrer da interação.

No inquérito UlBRICHT, os cinco participantes, todos homens, discutem os rumos da política da RDA com a passagem do poder de Ulbricht para Honecker, o que é denominado "o fim da era Ulbricht".

O inquérito EXTERIOR reúne seis participantes do sexo masculino, os quais discutem a política da RFA quanto à divulgação da cultura alemã fora da Alemanha e às organizações de propagação da cultura alemã (Goethe Institut, DAAD), seus objetivos e forma de atuação.

O inquérito discriminado como SEXO tem como temas o sexo antes do casamento e a fidelidade, discutindo-se aspectos físicos, morais e sociais. Dos nove participantes, dois são mulheres, um dos homens é padre, outro, educador e ainda um terceiro recebe de um dos demais a denominação de 
"representante da nova geração". O clima da discussão é bastante franco e amistoso.

No inquérito ALEMÃO, discute-se a didática e as linhas-mestras das aulas de alemão nas escolas secundárias da RFA. Os falantes são seis, dentre os quais uma única mulher, professora de alemão. Os demais são um professor universitário de literatura, um estudante do Gymnasium (correspondente ao nosso colegial), um estudante universitário do curso de germanística, um professor-assistente universitário e um ex-senador para assuntos da educação de Berlim Ocidental. Os participantes discutem, ainda, a relação entre ensino e pesquisa universitários em língüística e estudos literários e sua aplicação (ou não) nas aulas da escola secundária.

Se no inquérito anterior já se pode notar um certo antagonismo velado, devido ao fato de os participantes tenderem a justificar o desempenho de seu grupo profissional na questão, o inquérito ABORTO, pelo próprio tema, já prenuncia a polêmica e o acirramento dos ânimos que efetivamente acontece, principalmente porque os participantes foram escolhidos em razão de suas opiniões antagônicas sobre o assunto, a proposta de modificação da lei alemã, a qual proibia totalmente o aborto. Seis debatedores, entre os quais duas médicas com opiniões opostas a respeito do tema, dois professores universitários e dois advogados, discutem a partir de quando deve-se considerar que tem início a vida (já no sêmen, com a concepção, a fixação do óvulo no útero etc.), pois que a Constituição alemã garante o direito à vida e, com base nesse pressuposto, considerava o aborto como crime. A discussão abrange também questões como o fato de mulheres alemãs viajarem à Inglaterra para fazer abortos, a ética médica frente ao problema e o direito de decisão da mulher. É interessante notar que o maior antagonismo e agressividade se estabelece justamente entre as duas médicas.

O último inquérito, MODERADORES, é exatamente o oposto. Embora haja divergências, o clima é sempre amistoso, como uma conversa entre colegas. Participam da discussão apenas moderadores de programas políticos e culturais, sendo que, de nove participantes, apenas um é do sexo feminino. Os tópicos debatidos são: a própria figura do moderador e seu papel nos programas que apresentam, a necessidade ou não de um moderador fazer comentários sobre reportagens já prontas e a composição e funcionamento de uma redação jornalística.

Os inquéritos são, portanto, bastante diversificados em relação aos temas abordados, à profissão, sexo e idade dos participantes, fornecendo, 
assim, um material que deve apresentar-se pouco viciado no que se refere às especificidades trazidas pelos participantes como indivíduos.

\subsection{Procedimentos}

Definido o corpus, localizamos nos inquéritos as ocorrências de Dissensão, conforme sua definição apresentada no ítem 1.1.2 do Capítulo I. Em cada ocorrência, analisamos as Estratégias de Trabalho da Face e os meios lingüísticos utilizados, com base nas estratégias de Brown \& LEVINSON constantes do ítem 1.3.5 do Capítulo I. Procuramos, em seguida, sistematizar as realizações lingüísticas e as estratégias identificadas, a fim de propor esquemas de expressão da Dissensão mais comumente utilizados por falantes alemães, conforme encontrados no corpus.

\subsubsection{Levantamento das ocorrências}

Durante o processo de localização das ocorrências para posterior análise, deparamo-nos com dois casos particulares de Dissensão, cujas peculiaridades são importantes para a sua inclusão no corpus do presente trabalho.

Conforme mencionamos no item 1.1.2, a Dissensão ocorre como um conflito entre a convicção do falante e sua representação mental do que ele julga ser a opinião de seu interlocutor. Assim, o falante pode inclusive expressar sua Dissensão referente a fatos e/ou opiniões que ele atribui ao seu interlocutor, mesmo que tais fatos e/ou opiniões não tenham sido expressos por ele. Mesmo sem nenhum pronunciamento explícito do interlocutor, o falante discorda preventivamente, contrariando os autores dos trabalhos examinados no item 1.1.1. No exemplo a seguir, uma adolescente, interpelada sobre o porquê de alegrar-se quando os pais não estavam em casa, discorda preventivamente de uma possível opinião da interlocutora: 
ich kann ihnen eine relativ dumme Antwort darauf geben. das geht bei mir nich etwa so, daß ich dann irgendwelche Freunde empfangen will oder so [...], sondern [..] daß ich sage (ach) (wie schön) ich kann mal lange Fernsehen gucken... (inquérito MAE)
(Eu posso lhe dar uma resposta relativamente boba. Não é que eu queira receber uns amigos ou algo assim, [...] mas sim [...] que eu posso dizer: ah, que bom, eu posso ver televisão por mais tempo...

Porém, como nossa definição de Dissensão ampara-se no conceito de Relevância de SPERBER \& WILSON, consideramos que neste tipo de expressão da Dissensão evidencia-se um confronto entre as opiniões pessoais atribuídas ao falante e ao interlocutor durante a interação e, assim, tais ocorrências também foram contempladas neste estudo.

Durante a discussão, pode acontecer ainda um outro tipo de Dissensão, a qual não se refere às opiniões atribuídas ao interlocutor pelo falante, mas sim, à Dissensão deste último com relação a pessoas ou instituições que não estão representadas diretamente na interação, como no exemplo:

[...] auch ein paar Sätze zu den einzelnen Punkten zunächst mal Literatur die Rolle der Literatur in Verbindung zur Kritikfähigkeit oder das $+g^{+}$die Möglichkeit zu schaffen, daß man kritikfähig wird:, wenn man Literatur mei:nes Erachtens richtig versteht, dann gibt sie dazu von vornherein Anlaß. Literatur ist ja immer ein Ferment: gewesen und is auch heute gegen Erstarrung und Dogmatisierung auch ideologische Dogmatisierung. $+g+$ diese Perspektive mu $\beta$ man allerdings erkennen und die Literatur nicht dann nur zum Vehikel nehmen um irgendwas vom Dogma beweisen zu wollen. (inquérito ALE)
(Ainda algumas palavras sobre os pontos em particular: primeiramente: literatura, o papel da literatura em relação à capacidade crítica ou hã... a possibilidade de fazer com que as pessoas se tornem capazes de criticar; do meu ponto de vista, quando se entende literatura adequadamente, então ela já fornece motivo para tal. Literatura sempre foi um ferme:nto, e ainda o é, contra a imobilidade e o dogmatismo, também o dogmatismo ideológico. hã... esta perspectiva deve ser reconhecida e a literatura não tomada tão somente como veículo para que se prove algo referente a um dogma.)

Aqui, o falante expressa sua opinião contrária a um entendimento de literatura que ele julga equivocado, mas que não é atribuído específicamente a nenhum dos demais participantes da interação. Não fica claro quem teria tal entendimento da literatura, criando uma Dissensão com um participante suposto, que pode ser a sociedade como um todo ou um pequeno grupo indefinido de pessoas. 
Tal fenômeno, já apontado por Ducrot, é denominado negação polêmica em BARROS (1993: 145), e não foi considerado neste estudo, pois que nem sempre constitui uma Dissensão com relação aos demais participantes da discussão, podendo, inclusive, ser um recurso para reassegurar mutualidade e pertença ${ }^{17}$ a um mesmo grupo, como no caso do inquérito RDA, no qual praticamente todas as Dissensões referem-se às idéias e ao modo de vida da República Federal Alemã, contrapostas às da República Democrática Alemã, com as quais os participantes se identificam completamente.

Ocorrências deste último caso, em que a Dissensão ocorre frente a um interlocutor não presente à interação, não serão, portanto, contempladas neste trabalho, ao contrário do primeiro exemplo, no qual o falante discorda preventivamente de um interlocutor presente à interação, pois que consideramos para este estudo as ocorrências de Dissensão com relação a opiniões que, com base nos elementos lingüísticos da totalidade da interação e no Princípio de Relevância de SPERBER \& WILSON, puderam ser identificadas como atribuídas pelo falante aos seus interlocutores diretos.

Com base nesses parâmetros, foram levantadas as ocorrências de Dissensão nas Discussões listadas no item 2.1.2 e que constituem o corpus desta pesquisa. É necessário mencionar que os dados do corpus assim obtidos não pretendem esgotar todas as possíveis ocorrências de Dissensão nos inquéritos analisados, pois examinaremos também ocorrências de Dissensões off record, as quais só podem ser detectadas a partir das pistas fornecidas pelo falante. A interpretação de tais pistas, se é realizada em geral de forma adequada pelos participantes da interação, pode, em alguns casos, escapar ao pesquisador, a quem faltam elementos extralingüísticos para tal interpretação (como conhecimento pessoal dos falantes, de sua história comum anterior, de suas relações pessoais etc.). Assim, nada impede que algumas ocorrências de Dissensão implícita tenham passado desapercebidas neste levantamento. Porém, como o objetivo do trabalho não é uma análise estatística rigorosa das realizações lingüísticas e das Estratégias de Trabalho da Face utilizadas para a expressão da Dissensão, não cremos que possíveis omissões venham a afetar os resultados.

Em conformidade com o apresentado por SPRANZ-FogASY, consideramos que todas as expressões de Dissensão referentes a um mesmo

\footnotetext{
${ }^{17}$ Este termo provém da teoria matemática dos conjuntos, sendo que se diz que um elemento pertence a um determinado conjunto quando está enumerado entre os objetos, ou noções, cuja reunião constitui tal conjunto ou quando ela está implicada da definição do conjunto (cf. DuBOIS, 1996: 466).
} 
conteúdo proposicional, dentro de um mesmo turno, configuram apenas uma ocorrência de Dissensão, como no exemplo:

[...] (ja) sie haben aber noch immer $+g+$ trotzdem immer noch das Gefühl (ja) wenn ich mich mal verhaue, dann sind aber die Eltern wieder da [...] wenn man allein ist, dann ist man aber viel mehr auf sich gestellt. dann kann man viel mehr lernen [...] (MAE5)

No exemplo acima, a falante discorda da opinião de outra participante, de que não é necessário deixar a casa dos pais para ser independente. A falante apresenta dois argumentos contra essa opinião: a) tem-se sempre a idéia de que os pais estarão lá para ajudar em qualquer dificuldade; b) quando se está sozinho, sem poder contar com ninguém, aprende-se muito mais. Apesar de serem argumentos diferentes, ambos contestam apenas uma idéia do interlocutor e são assim, para este estudo, considerados como uma única ocorrência de Dissensão.

Freqüentemente, a expressão de uma única ocorrência de Dissensão apresenta vários argumentos, por vezes até digressões, que não se apresentam sempre como pertinentes a este estudo. Assim sendo, a fim de facilitar a leitura e a compreensão dos exemplos provenientes do corpus, em diversos casos foram suprimidos trechos que não afetam a análise, indicados com reticências entre colchetes ([...]). Freqüentemente, a fim de facilitar a compreensão da ocorrência de Dissensão, é também apresentada entre colchetes, ao início do exemplo, a intervenção do interlocutor que motivou a Dissensão do falante.

\subsubsection{A classificação das ocorrências}

Examinando cada uma das ocorrências levantadas, constatamos que a Dissensão pode ter como foco a forma da expressão lingüística utilizada pelo interlocutor, restringir-se a um determinado item de uma proposição apresentada pelo interlocutor, estender-se ao valor de verdade de toda uma proposição ou dirigir-se ao rumo que o interlocutor está imprimindo à interação.

Neste particular, nosso conceito de Dissensão vai ao encontro do conceito de "heterocorreção" utilizado por BARROS (1993). A autora caracteriza a correção como:

"[...] um procedimento de reelaboração do discurso que visa a consertar seus 'erros'. O 'erro' deve ser entendido como uma escolha do falante - lexical, 
sintática, prosódica, de organização textual ou conversacional - já posta no discurso que, por razões diversas ele e/ou seu interlocutor consideram inadequada." (BARROS, 1993: 136)

As correções dirigidas à contribuição do próprio falante são denominadas autocorreções, e aquelas dirigidas a intervenções do interlocutor são denominadas heterocorreções.

Quanto à sua possibilidade de atingir todos os níveis, do lexical ao pragmático, esta definição de correção é muito semelhante à nossa Dissensão, porém, a correção pode ser feita pelo falante com referência à sua própria contribuição à interação, enquanto a Dissensão refere-se apenas a contribuições ou opiniões atribuídas ao interlocutor. Além disso, a Dissensão pressupõe representações mentais conflitantes, o que teoricamente não ocorre quando se trata das representações mentais do mesmo indivíduo.

Desse modo, procedemos a uma primeira classificação das expressões de Dissensão que compõem o corpus da pesquisa. Constatamos que uma Dissensão pode ter por objeto:

i) a utilização, por parte do interlocutor, de elementos lingüísticos que o falante julga inadequados;

ii) uma representação mental que constitui parte ou

iii) o todo de uma proposição atribuída ao interlocutor, ou ainda

iv) o rumo da interação, ou seja, uma Dissensão em nível supraproposicional.

Partindo destas observações, sugerimos uma classificação das ocorrências de Dissensão, segundo seu objeto, em quatro categorias, que detalhamos a seguir.

\subsubsection{Dissensão referente à Expressão Lingüística do interlocutor}

As Dissensões que se referem apenas à forma de expressão utilizada pelo interlocutor têm, do ponto de vista do falante, um caráter corretivo de constituintes da proposição sem, no entanto, pretender excluí-los da mesma. Neste caso, o falante destaca um elemento lexical que ele considera inadequado ou equivocado dentro de uma proposição apresentada pelo interlocutor e sinaliza sua Dissensão com relação a este último, geralmente apresentando razões para a sua discordância, como no exemplo: 
ich halte die Bezeichnung nationaler Notstand und und finsteres Mittelalter für übertrieben und spektakulär... (MEN1)

no qual o falante sinaliza sua insatisfação com os termos utilizados pelo interlocutor, nationaler Notstand (estado de calamidade nacional) e finsteres Mittelalter (idade das trevas), para descrever o sistema de saúde da Alemanha no que se refere às doenças mentais, caracterizando-os como "exagerados e espetaculares".

\subsubsection{Dissensão referente a Parte de uma Proposição}

Nesta categoria de Dissensão, o falante sinaliza ao interlocutor que uma proposição introduzida por este último na discussão (ou uma proposição que lhe é atribuída pelo falante) choca-se parcialmente com sua representação mental sobre um determinado conteúdo.

No caso de uma Dissensão parcial frente a uma proposição, o falante corrige o interlocutor quanto a pontos específicos dentro de uma proposição, sem contudo contestar o valor de verdade da mesma, normalmente apresentando o item alternativo que ele julga mais adequado, como no seguinte exemplo:

[von Meklenburg bis...] (nein) (nein) ich sprach nur von Meklenburg (RDA1)

Neste caso, quando o interlocutor afirma que o programa atinge ouvintes da região "de Meklenburg até...", o falante intervém e o corrige, apresentando a alternativa correta, de que ele havia citado somente Meklenburg.

\subsubsection{Dissensão referente à Totalidade de uma Proposição}

O segundo tipo de Dissensão referente à proposição encontrado no corpus refere-se à sua totalidade, ou seja, questiona seu valor de verdade, sendo que o falante opõe-se completamente à representação de conteúdos e atitudes que ele atribui ao seu interlocutor. Entendemos que este caso é o protótipo da Dissensão, pois as representações apresentadas pelo interlocutor ou que lhe são atribuídas pelo falante apresentam-se, na grande maioria dos casos, sob a forma de proposições, como na ocorrência: 
(ja) ich glaube nicht, daß die so sentimental sind, daß also den Umstand Lenin gekannt zu haben sie all:zu sehr beeindruckt... (ULB3)

Aqui, o falante refuta a sugestão de um interlocutor, de que o fato de Ulbricht ter conhecido Lenin poderia ter tido reflexos em sua carreira política.

\subsubsection{Dissensão referente ao Rumo da Interação}

A quarta possibilidade de Dissensão foge ao âmbito da proposição e tem efeitos sobre a interação como um todo, detendo-a e/ou reorientando-a. Tal tipo de Dissensão já foi apontada por APELTAUER, no esquema aqui apresentado no item 1.1.1.2, sob a forma de "atos de fala não-concordantes concluidores de seqüências", e por WeINRICH, quando, referindo-se à negação, menciona que a mesma pode ser utilizada para rechaçar uma expectativa derivada da informação prévia (Vorinformation) da interação e, assim, deter ou imprimir uma nova orientação ao processo de comunicação (cf. WeINRICH 1976: 81). Entendemos que o mesmo se aplica à Dissensão, quando o falante discorda do rumo proposto pelo interlocutor e procura impedir tal direcionamento, expressando sua não-concordância com o mesmo, bloqueando seu plano para a interação. $\mathrm{O}$ interlocutor pode, no entanto, aceitar o bloqueio ou rejeitá-lo através de nova Dissensão, como no seguinte exemplo:

A: Obwohl wir hier jetzt nicht laute Zitate ... möchten.

B: (nein) aber grade weil das auch ein Zitat war von dem englischen Gesundheitsminister... (GEI5 e 6)

Quando B expressa o desejo de fazer uma citação sobre o tema da saúde mental que está sendo discutido, A tenta bloqueá-lo dizendo que os participantes não gostariam de ouvir uma batelada de citações. B, no entanto, não aceita o bloqueio e expressa sua Dissensão, justificando a pertinência da citação para o tema em questão.

Após a classificação das ocorrências do corpus como exemplos de Dissensão referentes 1) à expressão lingüística, 2) a parte ou 3) ao todo da proposição e 4) ao rumo da interação, estas foram tabuladas por inquérito, sendo os resultados apresentados no Capítulo 3. 


\subsubsection{As Estratégias de Trabalho da Face}

Localizadas as ocorrências de expressão da Dissensão e classificadas em relação às quatro categorias apresentadas no item anterior, analisamos as Estratégias de Trabalho da Face empregadas em cada ocorrência. Para tanto, utilizamos como base o elenco de estratégias desenvolvido por BROWN \& LEVINSON e apresentado no item 1.3.5. Conforme os autores enfatizam, tal elenco não pretende ser completo, podendo-se acrescentar novas estratégias ou variações daquelas propostas, o que fizemos, sempre que necessário. Partimos, porém, do princípio de que todas as estratégias formais obedecem às quatro grandes super-estratégias de Expressão Direta, Compensação Positiva, Compensação Negativa e Expressão off record. Consideramos como Estratégias de Compensação Positiva aquelas que procuram acentuar o caráter de cooperação entre os falantes e de pertença a um mesmo grupo, de compartilhamento de interesses comuns, e como compensação negativa aquelas estratégias que procuram um distanciamento entre os interlocutores, ou entre estes e a Dissensão, a fim de evitar invasões de privacidade e falta de respeito.

Ainda conforme os autores citados, as diversas Estratégias de Trabalho da Face podem ser combinadas para obter o efeito desejado pelo falante. Assim, não procuramos associar cada ocorrência de Dissensão a uma estratégia única ou dominante, mas sim, apontar todas as estratégias utilizadas em cada uma delas.

Após a identificação das estratégias utilizadas, estas foram tabuladas por inquérito e relacionadas com as categorias da primeira classificação (referentes a forma, proposição total ou parcial e interação).

\subsubsection{A realização lingüística das Estratégias de Trabalho da Face na Dissensão}

A partir da classificação das Estratégias de Trabalho da Face utilizadas nas ocorrências de Dissensão, procedeu-se a um levantamento dos meios lingüísticos utilizados para realizá-las, com a posterior tabulação em relação à categoria de Dissensão e Estratégias de Trabalho da Face.

Os resultados obtidos são apresentados e discutidos nos Capítulos III e IV. 


\section{CAPÍTULO III - ANÁLISE DAS OCORRÊNCIAS E DISCUSSÃO DOS RESULTADOS}

\subsection{Freqüência de ocorrência das categorias de Dissensão}

Após o levantamento da Dissensão no corpus da pesquisa, chegou-se total de 376 ocorrências, assim distribuídas:

\section{Inquérito}

ABORTO

ALEMÃO

ALMÔNDEGAS

COALIZÃO

EXTERIOR

GUERRA

MÃES

MENTAL

MODERADORES

RDA

SEXO

TRÂNSITO

ULBRICHT

\section{$N^{\circ}$ de Ocorrências}

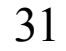

16

32

35

13

74

43

19

6

2

13

70

22

Em uma primeira análise, verificou-se a freqüência de cada uma das quatro categorias de Dissensão, a saber, referente à Expressão Lingüística, a Parte ou à Totalidade da Proposição e ao Rumo da Interação. Quanto a este ponto, as ocorrências de Dissensão estão assim distribuídas:

\begin{tabular}{|c|c|c|c|}
\hline Expr.Lingüística & Prop/parcial & Prop/total & Interação \\
\hline 11 & 10 & 314 & 41 \\
\hline
\end{tabular}

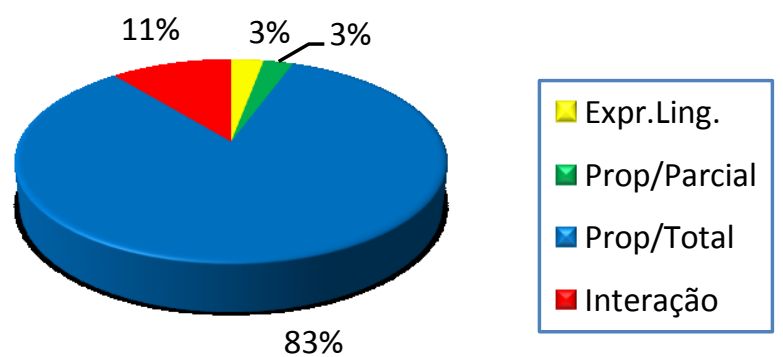


No que se refere a cada inquérito, a distribuição é a seguinte:

\begin{tabular}{|l|c|c|c|c|}
\hline \multicolumn{1}{|c|}{ INQUÉRITO } & $\begin{array}{c}\text { EXPR. } \\
\text { LGTICA. }\end{array}$ & $\begin{array}{c}\text { PROP/ } \\
\text { PARCIAL }\end{array}$ & $\begin{array}{c}\text { PROP/ } \\
\text { TOTAL }\end{array}$ & $\begin{array}{c}\text { RUMO } \\
\text { INTERAÇÃO }\end{array}$ \\
\hline ABORTO & 1 & 0 & 26 & 4 \\
\hline ALEMÃO & 1 & 1 & 14 & 0 \\
\hline ALMÔNDEGAS & 0 & 1 & 27 & 4 \\
\hline COALIZÃO & 2 & 2 & 24 & 7 \\
\hline EXTERIOR & 1 & 0 & 11 & 1 \\
\hline GUERRA & 1 & 4 & 58 & 11 \\
\hline MÃES & 1 & 0 & 39 & 3 \\
\hline MENTAL & 1 & 0 & 16 & 2 \\
\hline MODERADORES & & 0 & 5 & 1 \\
\hline RDA & & 2 & 0 & 0 \\
\hline SEXO & 1 & 0 & 10 & 2 \\
\hline TRÂNSITO & 2 & 0 & 62 & 6 \\
\hline ULBRICHT & & 0 & 22 & 0 \\
\hline TOTAIS & 11 & 10 & 314 & 41 \\
\hline
\end{tabular}

Observando-se os resultados, pode-se constatar que a grande maioria dos casos de Dissensão em discussões $(83,51 \%)$ refere-se à totalidade de proposição que o falante atribui ao interlocutor ou que este the apresentou durante a interação, quando o falante contesta o seu valor de verdade.

Os casos de Dissensão referentes ao rumo da interação são bem menos freqüentes $(10,9 \%)$, o que era previsível, pois normalmente se espera que os participantes de uma interação respeitem as regras da mesma e colaborem para manter um rumo que seja conveniente a todos os participantes. Deve-se ter em conta que, em todos os inquéritos, está presente a figura de um moderador, que tem o direito de limitar o tempo de participação de cada falante e também de sugerir novos rumos para a discussão.

Os casos nos quais o falante sinaliza que considera equivocado ou inadequado um elemento de uma proposição apresentada pelo interlocutor são os menos freqüentes no corpus $(2,65 \%)$. Tal resultado também era esperado, pois supõe-se que o interlocutor tem todos os dados necessários para apresentar uma proposição da forma mais adequada à interação, mas que ele não está livre de cometer enganos ocasionais por falta de informação 
ou estar sujeito a mal-entendidos ocorridos durante a interação. É interessante observar que, no inquérito RDA, este é o único tipo de Dissensão encontrado, o que não acontece em qualquer um dos demais inquéritos. Este inquérito é também atípico pelo fato de apresentar apenas duas ocorrências de Dissensão em 28 minutos de discussão, quando o inquérito que mais se aproxima desse valor apresenta seis ocorrências de Dissensão em aproximadamente onze minutos, com apenas um caso de Dissensão referente a Parte da Proposição. Tal particularidade do inquérito RDA nos leva a especular se o fato de o inquérito provir de um programa de discussões da televisão estatal da República Democrática Alemã, na época em o regime comunista estava no auge, e de o assunto discutido (resultados da safra agrícola) referir-se aos planos elaborados pelo governo algum efeito repressivo em relação à expressão de Dissensões.

Quanto às Dissensões referentes à forma de expressão lingüística utilizada da pelo interlocutor, estas apresentam uma freqüência semelhante à da Dissensão referente a elementos da proposição $(2,92 \%)$, possivelmente devido às mesmas razões expostas anteriormente com relação a esse item. Porém, é muito interessante notar que em exatamente metade dos casos de Dissensão referente à Expressão Lingüística, o que realmente se quer contestar não é o termo em si, mas sim, o uso que o interlocutor faz do mesmo. implicando, assim, uma crítica velada às suas opiniões. Tal uso da Dissensão referente a formas lingüísticas corresponde a um uso da linguagem abordado por BLÜHDORN (1995: 103ss.) sob a rubrica Zeichenkritik ('crítica do signo'), especialmente nos casos em que a crítica, supostamente dirigida ao modo de expressão, realmente encobre uma crítica à posição ou à estratégia interacional proposta pelo interlocutor. A obra citada refere-se a estratégias retóricas na comunicação política, e é interessante notar que, em cinco ocorrências deste uso da crítica do signo em nosso corpus, duas encontram-se no inquérito COALIZÃo, do qual participam quase exclusivamente políticos, sendo que, nos outros três inquéritos que apresentaram tal uso da Dissensão, houve apenas uma ocorrência em cada um.

A seguir, apresentamos os resultados do uso de estratégias de Trabalho da Face para expressão das ocorrências de Dissensão no corpus e sua freqüência quanto às quatro categorias de Dissensão. 


\subsection{A Dissensão e as Estratégias de Trabalho da Face}

Partindo do esquema das quatro super-estratégias de Polidez (propostas por BROWN \& LEVINSON e aqui apresentadas no item 1.3.1, dividimos as ocorrências encontradas em dois grandes grupos, sendo que o segundo, por sua vez, ramifica-se em três sub-grupos:

a) ocorrências de expressão da Dissensão off record., realizadas unicamente de acordo com a super-estratégia $\mathrm{n}^{\circ} 4$ - fazer o FTA implicitamente;

b) ocorrências de expressão da Dissensão on record, realizadas:

bl) diretamente, sem compensação, de acordo com a superestratégia $n^{\circ} 1$ - fazer o FTA explicitamente, sem ação de compensação (bald on record);

b2) diretamente, com ação de compensação baseada na polidez positiva, conforme a super-estratégia $\mathrm{n}^{\circ} 2$;

b3) diretamente, com ação de compensação baseada na polidez negativa, conforme a super-estratégia $\mathrm{n}^{\circ} 3$.

Cabe notar que, dentro de uma mesma ocorrência de expressão de Dissensão, é possível usar-se mais de uma dessas super-estratégias, inclusive combinando-as de várias maneiras. Desse modo, constatamos 897 ocorrências de Estratégias de Trabalho da Face na expressão de Dissensões no corpus da pesquisa.

Após a análise de tais ocorrências, constatamos que todas as quatro super-estratégias de Expressão direta sem compensação, de Compensação Positiva, Compensação Negativa e Estratégias off record (estas últimas, como estratégia única ou auxiliar) foram utilizadas na expressão de Dissensões, nas seguintes proporções:

FreqüênCIA DE OCORRÊnCIA de SUPER-ESTRATÉgIAS de Trabalho da FACE nO CORPUS DA PESQUISA
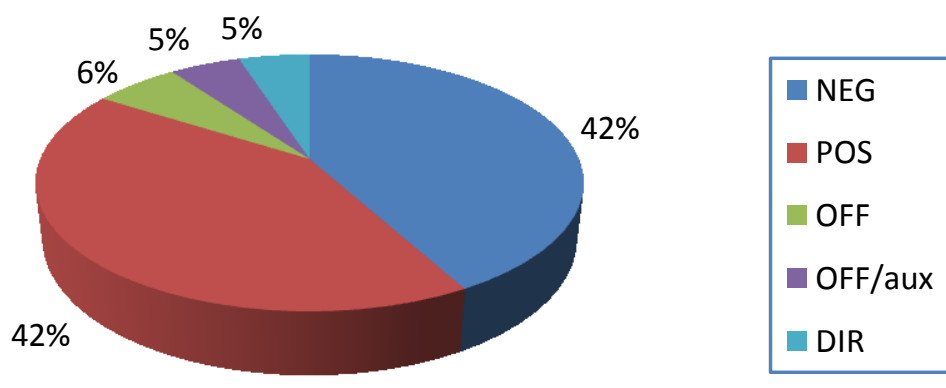
O exame do gráfico permite constatar que a estratégia de apresentar a Dissensão diretamente, sem ação de compensação, foi a menos utilizada (4,68\%), o que contesta a citação de Goethe, de que "em alemão, mente-se quando se é gentil".

No corpus da pesquisa, as Estratégias de Compensação Positiva e Negativa ocorreram praticamente na mesma proporção (respectivamente $42,99 \%$ e $42,25 \%$ ), o que parece comprovar a tese de BROWN \& LEVINSON, de que os participantes de uma interação afastam-se e aproximam-se mutuamente, buscando o equilíbrio entre as necessidades de suas Faces e daquelas dos interlocutores.

Quanto às estratégias off record como as únicas utilizadas para expressar a Dissensão, sua pequena porcentagem de ocorrência $(5,79 \%)$ parece confirmar a opinião de SPRANZ-FOGASY, de que os falantes sentem a necessidade de sinalizar claramente suas 'contradições' (em seu estudo, compreendendo a grosso modo à nossa Dissensão).

No entanto, estratégias off record também podem ser utilizadas como estratégias de compensação em Dissensões diretas. A porcentagem de estratégias off record utilizadas desta maneira é de 4,57\%. Se considerarmos que tal uso destas estratégias é um caso extremado de Compensação Negativa, então, a porcentagem de uso de Estratégias de Compensação Negativa ultrapassa ligeiramente a de Compensação Positiva (respectivamente, $42,69 \%$ e 46,82\%).

Conforme detalhado no item 1.3.5, as quatro super-estratégias realizam-se através de diversas estratégias subordinadas, as quais são listadas nos esquemas constantes daquele item. A hierarquização das estratégias ali apresentadas é explicada por BROWN \& LEVINSON da seguinte maneira: as quatro estratégias de nível mais elevado (fazer o FTA diretamente, polidez positiva, polidez negativa $\mathrm{e}$ fazer o FTA implicitamente) são denominadas "super-estratégias". Delas derivam estratégias de segunda ordem, que acabam por desembocar em estratégias formais (output strategies) referentes à expressão efetiva do FTA (cf. BROWN \& LEVINSON, 1979: 97). A hierarquia das estratégias mostra como o falante. em primeiro lugar, decide-se por realizar a Dissensão implícita ou explicitamente, com ou sem ação de compensação. Em seguida, seleciona uma das estratégias de segunda ordem e, partindo desta, resolve-se por uma das estratégias formais que dela derivam, para atingir seu objetivo de expressar a Dissensão do modo que julga mais adequado quanto ao Trabalho da Face em um determinado ponto da interação. 
Embora tomemos as estratégias formais apresentadas nos esquemas de BROWN \& LEVINSON como ponto de partida para a nossa análise, o estudo das ocorrências do corpus levou-nos a modificar ou acrescentar novas estratégias àquelas apresentadas por estes autores. As estratégias formais em sua obra baseiam-se principalmente na análise de solicitações e críticas, provavelmente por serem os exemplos mais claros de um ato que ameaça as Faces. Solicitações e críticas são também, na maioria das vezes, muito fáceis de serem observadas e analisadas, por serem, em geral, explícitas e breves (quando comparadas, por exemplo, a uma negociação, que se estende por vários turnos). Desse modo, não se pode esperar que tal elenco de estratégias surja em todas as demais possíveis situações de Trabalho da Face, ou ainda, que essas sejam as únicas estratégias formais possíveis para o Trabalho de Face frente a outros tipos de FTAs. Os autores não mencionam. em qualquer momento, a intenção de considerar tal listagem exaustiva, o que nos deixa a possibilidade de que outras estratégias formais possam ser adicionadas à mesma, ou que possam ser reformuladas parcialmente.

As peculiaridades do FTA analisado em nosso estudo, a Dissensão, certamente influenciaram sobremaneira as estratégias formais mais utilizadas para realizá-lo. Ao se discordar de alguém não é costume, por exemplo, oferecer-lhe presentes (estratégia de polidez positiva $n^{\circ} 15$ de BROWN \& LEVINSON) como forma de compensação pelo "dano" à Face. Assim, algumas das estratégias formais apontadas por BROWN \& LEVINSON mostraram-se especialmente privilegiadas na expressão da Dissensão, outras não chegaram a ocorrer no corpus da pesquisa.

Por outro lado, algumas das estratégias formais indicadas por esses autores mostraram-se insuficientemente detalhadas, em sua formulação original, para explicitar os mecanismos lingüísticos que as realizam, como no caso da estratégia que denominamos relativize a opinião do interlocutor, uma realização especial da estratégia evite discordância de BROWN \& LEVINSON. Em alguns casos, portanto, reformulamos as estratégias formais originais, porém, permanecendo fiéis às superestratégias às quais pertenciam.

Desse modo, as super-estratégias (sublinhadas), estratégias de segunda ordem (em itálico) e estratégias formais efetivamente utilizadas para a expressão da Dissensão no corpus da pesquisa encontram-se assim distribuídas: 
Dissensão off record:

Crie implicaturas - manipule o Princípio de Relevância

a) dê pistas para associações

b) seja irônico

c) seja vago

d) exagere

Dissensão on record:

Dissensão Direta, sem Ação de Compensação

Apresente uma proposição contrária à contribuição do interlocutor

Dissensão Direta com Estratégias de Compensacão Positiva

Alegue pontos em comum:

a) Evite discordância

ai) Concorde simbolicamente

a2) Relativize a opinião do interlocutor

b) Busque concordância: relativize a própria opinião

c) Crie/pressuponha pontos comuns

d) Intensifique o interesse: aproxime o interlocutor

e) Graceje

f) Use identificadores grupais

Apresente H e $\mathrm{S}$ como colaboradores

g) Dê (ou peça) razões

h) Inclua falante e interlocutor na atividade: gerencie a dêixis pessoal

i) Seja otimista

Dissensão Direta com Estratégias de Compensacão Negativa

Seja convencionalmente indireto

a) Utilize formas convencionalizadas 
Não presuma/imponha: negocie o grau de certeza e de responsabilidade:

b) Relativize a própria opinião

c) Evite afirmações: faça perguntas

d) Gerencie o grau de realidade

Não coaja $H$

e) Minimize a imposição

f) Dê deferência

Comunique a vontade de não impingir: afaste a imposição

g) Afastamento pessoal: impersonalize:

gl) Gerencie a dêixis pessoal

g2) Apele à objetividade/autoridade

g3) Invoque regras gerais

g4) Defocalize os participantes

h) Afastamento temporal: gerencie a dêixis temporal

i) Afastamento epistêmico: use verbos modais

j) Indique relutância

1) Peça desculpas

Conforme já mencionado por BROWN \& LEVINSON e apresentado no item 1.3.5.4, por vezes estratégias off record podem ser utilizadas em combinação com estratégias on record. No corpus da pesquisa, encontramos também ocorrências deste uso combinado, o qual possibilita ao falante comprometer-se menos sem, no entanto, correr o risco de que sua Dissensão seja ignorada pelo interlocutor. A análise do corpus apresentou usos das seguintes estratégias off record em combinação com estratégias diretas:

a) Dê pistas para associações

b) Seja irônico

c) Faça perguntas retóricas

d) Seja incompleto

e) Exagere

f) Use metáforas

g) Seja vago

Nos itens a seguir, apresentamos os resultados referentes à análise do uso das diversas estratégias formais nos inquéritos constantes do corpus da 
pesquisa. É importante salientar novamente que aqui se encontram apenas as estratégias que efetivamente ocorreram em nosso corpus, as quais não contemplam a totalidade daquelas sugeridas por BROWN \& LEVINSON. No Capítulo IV, apresentamos comentários a respeito da preferência de determinadas estratégias em detrimento de outras com relação à Dissensão.

As ocorrências de Dissensão encontradas no corpus estão listadas no Anexo, organizadas por inquérito e acompanhadas de uma legenda, da qual constam as Estratégias de Trabalho da Face utilizadas para sua expressão. Nos itens que se seguem, discutiremos os resultados da análise referentes a essas estratégias e às suas realizações lingüísticas, apresentando e discutindo alguns exemplos ilustrativos de cada caso. No Anexo, todas as estratégias encontram-se indicadas na legenda, classificadas em Dissensões off Record (OFF), Dissensões diretas (DIR), Dissensões diretas com estratégias de compensação positiva (COMP+) e negativa (COMP-) e estratégias off record utilizadas como auxiliares na compensação de uma Dissensão direta (OFF/aux).

Apresentamos, a seguir, um exemplo de ocorrência de Dissensão listada no Anexo, bem como da sua análise:

(PROP/T) [...] ich weiß nicht, ob das immer etwas Gutes ist (nich?) ich will man kann es doch wohl kaum als gut bezeichnen, wenn in ganz bestimmten Ländern eben noch rückschrittliche Tendenzen herrschen. (ALE6, S. 4)

DIR. kaum, rückschrittlich

COMP+: ob immer... - evite discordância: relativize a opinião do interlocutor; nich?, eben - crie/ pressuponha pontos em comum

COMP-: ich weiß nicht - utilize formas convencionalizadas; man kann es... - gerencie A dêixis pessoal: impersonalize; wohl, kaum - relativize a própria opinião OFF/aux: in ganz bestimmten Ländern... - manipule a Máxima de Modo: seja vago

Ao início da ocorrência, encontra-se, entre parênteses, a classificação da Dissensão de acordo com as quatro categorias apresentadas no item 2.2.2. no caso, esta ocorrência é um exemplo de Dissensão referente à Totalidade da Proposição (PROP/T). Ao final da ocorrência, encontra-se a sigla do inquérito ao qual pertence e o seu número dentro do mesmo: este exemplo é a sexta ocorrência de Dissensão dentro do inquérito ALEMÃO. O falante discorda do interlocutor, que havia afirmado ser bom o fato de as linhas-mestras para o ensino da língua alemã nas escolas da RFA darem grande liberdade aos educadores. 
A legenda indica as Estratégias de Trabalho de Face utilizadas na expressão da Dissensão, apresentadas em negrito. Sob a sigla DIR encontram-se os elementos lingüísticos que caracterizam esta ocorrência como uma Dissensão direta: o interlocutor havia apresentado sua contribuição de forma positiva (ser bom); assim, o falante sinaliza diretamente sua Dissensão através de elementos com carga semântica negativa: doch, kaum e rückschrittlich. Os exemplos de Dissensão direta, sem estratégias de compensação, apresentam apenas este item na legenda.

Esta ocorrência em particular é um caso de Dissensão direta com estratégias de compensação, tanto positivas como negativas. $O$ falante inicia a Dissensão com uma forma convencionalizada (ich weiß nicht) que apresenta a vantagem de assinalar diretamente a Dissensão, ao mesmo tempo que demonstra a preocupação com as faces. Procura então estabelecer, através da pergunta negativa nicht?, pontos de consenso entre ele e o interlocutor que sirvam de base para o desenvolvimento da Dissensão que pretende apresentar. Como preparação, mostra o interesse em minimizá-la, relativizando a opinião do interlocutor através do elemento immer: o falante não nega a possibilidade da interpretação que o interlocutor atribui conteúdo (i.e. que ele seja bom), mas discorda que este seja sempre o caso. Em seguida, passa a intensificar a Dissensão, iniciando por ich will..., porém mudando de idéia e reformulando sua contribuição como man, utilizando-se da estratégia impersonalize: gerencie a dêixis pessoal, afastando-se, assim, da autoria da Dissensão, ao mesmo tempo que a relativiza com os elementos wohl e kaum. É interessante notar que, enquanto o elemento wohl diminui o grau de certeza da afirmação, o elemento kaum reafirma a negação do conteúdo "ser bom" apresentado pelo interlocutor. O falante mantém, assim, o equilíbrio entre suavizar a Dissensão, mas não a ponto de que ela não seja considerada pelo interlocutor.

Como argumento auxiliar para sua Dissensão, o falante apresenta um exemplo no qual a avaliação do interlocutor do conteúdo como "bom" não é aplicável. Porém, tal exemplo é apresentado através de uma estratégia off record listada sob a sigla OFF/aux.: o falante afirma que, em alguns estados da Alemanha, ainda imperam tendências retrógradas, embora não diga quais, sendo deliberadamente vago. Para compreender esta contribuição, o interlocutor precisa derivar várias implicaturas de acordo com o Princípio de Relevância: o que o falante considera como "tendências retrógradas"? Em quais estados da Alemanha estas tendências são aceitas como norma? Em que 
medida isto teria conseqüências com respeito às linhas-mestras do ensino de alemão? Ao expressar-se utilizando estratégias off record, o falante evita comprometer-se demasiadamente com sua Dissensão e com os efeitos que ela poderia provocar na interação com o interlocutor. Como não cita nominalmente os estados onde as "tendências retrógradas imperam", deixa ao interlocutor a possibilidade de entender a afirmação segundo seus próprios parâmetros, mesmo que estes não coincidam com os do falante. De qualquer maneira, o interlocutor é obrigado a concordar que, em estados com tendências retrógradas, sejam elas quais forem, as mesmas se perpetuariam com a liberdade oferecida pelas linhas-mestras em vigor, argumento que empresta força à Dissensão do falante com relação à sua contribuição (do interlocutor). $\mathrm{O}$ falante ainda intensifica a impressão de cumplicidade entre ele e o interlocutor ao utilizar-se da estratégia crie/pressuponha pontos em comum, através do elemento eben, para caracterizar a existência de tendências retrógradas como um fato que ambos conhecem e não contestam. Como está claro que o falante se responsabiliza pela Dissensão apresentada, esta estratégia off record é considerada como apenas auxiliar na compensação de Dissensão diretas.

Esta ocorrência é um bom exemplo de como os falantes utilizam-se ao mesmo tempo das duas possibilidades de compensação, ora aproximando-se do interlocutor, ora afastando-se dele e/ou da Dissensão, na tentativa de equilibrar suas necessidades de expressar a Dissensão de maneira clara e de não prejudicar demasiadamente tanto a sua Face quanto a do interlocutor.

Nos itens a seguir, apresentamos as diversas Estratégias de Trabalho de Face utilizadas para a expressão da Dissensão no corpus da pesquisa, bem como sua realização lingüística.

\subsubsection{Dissensão off record}

A manipulação do Princípio de Relevância, conforme formulado por SPERBER \& WILSON e resenhado anteriormente no item 1.2.2, pode levar a implicaturas conversacionais. Geralmente, implicaturas conversacionais são reconhecidas através da presença de um trigger, que leva o interlocutor a fazer determinadas inferências, derivadas daquilo que realmente foi dito. Conforme BROWN \& LEVINSON, fazer um FTA implicitamente é formulá-lo de modo que não seja possível atribuir claramente apenas uma intenção 
comunicativa ao ato (cf. BROWN \& LEVINSON, 1979: 216). Desse modo, é possível expressar a Dissensão através de implicaturas conversacionais, deixando ao falante uma forte escapatória, pois o interlocutor não pode claramente atribuir-lhe a intenção de discordar dele.

As ocorrências de estratégias off record na expressão da Dissensão estão assim distribuídas pelos diversos inquéritos:

\begin{tabular}{|l|c|c|}
\hline \multicolumn{1}{|c|}{ INQUÉRITO } & $\begin{array}{c}\text { ESTRATÉGIA } \\
\text { BÁSICA }\end{array}$ & $\begin{array}{c}\text { ESTRATÉGIA } \\
\text { AUXILIAR }\end{array}$ \\
\hline ABORTO & 0 & 4 \\
\hline ALEMÃO & 0 & 6 \\
\hline ALMÔNDEGAS & 0 & 12 \\
\hline COALIZÃO & 2 & 10 \\
\hline EXTERIOR & 1 & 2 \\
\hline GUERRA & 15 & 9 \\
\hline MÃES & 0 & 5 \\
\hline MENTAL & 0 & 0 \\
\hline MODERADORES & 0 & 0 \\
\hline RDA & 0 & 0 \\
\hline SEXO & 0 & 1 \\
\hline TRÂNSITO & 3 & 13 \\
\hline ULBRICHT & 0 & 0 \\
\hline TOTAIS & 21 & 62 \\
\hline
\end{tabular}

Dentro do corpus da pesquisa, foram encontradas 83 ocorrências de expressões off record de Dissensão. Dentre estas ocorrências, diferenciamos aquelas que tiveram a forma off record como estratégia básica para a expressão da Dissensão, daquelas nas quais a forma off record foi utilizada em combinação com estratégias diretas, de onde a razão, no gráfico anterior, da apresentação de itens separados para estratégias off record utilizadas como base e como auxiliares para a expressão da Dissensão.

De acordo com BROWN \& LEVINSON (op.cit., p. 217), estratégias off record utilizadas em contextos nos quais não há dúvidas sobre o objeto do FTA tornam-se, realmente, explícitas. Com base nesse raciocínio, as ocorrências de estratégias off record como ação compensatória, e não como expressão única da Dissensão, serão retomadas no item 3.2.2.6.

Os exemplos de expressão de Dissensão unicamente pelo uso de estratégias off record encontrados no corpus encontram-se indicados, sob a sigla OFF, nas ocorrências de Dissensão constantes do Anexo. As estratégias formais utilizadas nessas ocorrências são as seguintes: 


\subsubsection{Dê pistas para associações}

Muitos casos de implicaturas são provocados, dando-se ao interlocutor indicações sobre motivos ou condições que levariam ao FTA, no caso, à Dissensão, como no exemplo:

ich danke (Herr Heer) (also) $+g+$ behalten sie ihren Atem für die nächste Runde. (ABO10)

O falante agradece ao interlocutor e pede-lhe que "guarde seu fôlego para a próxima rodada". Este é um exemplo de Dissensão pela qual o falante impede o interlocutor de continuar no rumo que este imprimia à interação. Indagando-se por que deveria guardar o fôlego, já que não sente necessidade disso, interlocutor pode derivar a implicatura "cale-se".

Quase na mesma linha da estratégia anteriormente citada, o falante pode fornecer ao interlocutor pistas que, através de uma cadeia de associações, o leve a concluir que o falante discorda dele, como no exemplo:

ist das Neueste, was ich höre (also) die Klopse, die ich immer kriege... (ALM14)

Esta intervenção de uma falante segue-se ao comentário do interlocutor de que Klopse (uma espécie de hambúrger) são redondos. Ao afirmar que isto era "a maior novidade para ela" e ao mencionar os Klopse que ela conhece, o interlocutor pode inferir que ela nunca ouvira falar de Klopse redondos, e que os que ela conhece são diferentes, i.e. nãoredondos, implicando, assim, a Dissensão.

A implicatura conversacional pode também apoiar-se em pressuposições do falante com relação ao interlocutor. BROWN \& LEVINSON entendem pressuposições como "aquilo que é mutuamente pressuposto como conhecido" (cf. BROWN \& LEVINSON, 1978: 127), ou seja, conhecimentos type e token comuns aos participantes da interação.

$\mathrm{O}$ conhecimento type corresponde à visão de mundo de um determinado grupo social, suas expectativas quanto ao comportamento dos indivíduos e aos esquemas de funcionamento das diversas instituições sociais. O conhecimento token é um conhecimento particular, específico de 
um indivíduo ou de um grupo de pessoas ${ }^{18}$. Através da manipulação das pressuposições baseadas nesses conhecimentos, o falante pode implicitatemente discordar de seu interlocutor, como no exemplo:

(ja) ich möchte erst mal eine Bemerkung zu Herrn Pehlke machen. je enger und strenger solche Richtlinien sind (Rahmenrichtlinien für den Unterricht) $+g+$ desto $+g+$ weniger Möglichkeiten sind auch einer Mitbestimmung der Schüler angeräumt... (ALE4)

Esta observação do falante segue-se a uma proposta do interlocutor para que as linhas mestras das aulas de alemão fossem mais rígidas. $\mathrm{O}$ falante observa que linhas mais rígidas permitem menor possibilidade de atuação dos alunos. Baseado na pressuposição de que, na sociedade alemã contemporânea, a participação dos alunos nas aulas é algo altamente positivo, qualquer coisa que restrinja essa participação é considerada negativa. Desse modo, o interlocutor pode inferir a discordância do falante quanto à sua sugestão.

Como apresentamos no item 1.2.2, o Princípio de Relevância é realmente o único indispensável para a criação e decodificação de implicaturas. Porém, os conceitos Griceanos de Qualidade, Quantidade e Modo, como subcategorias do Princípio de Relevância, são muito úteis para analisar mais detalhadamente a criação de determinadas implicaturas. Assim, mantemos o esquema sugerido por BROWN \& LEVINSON para a realização das estratégias off record.

\subsubsection{Seja irônico}

Por ironia, BROWN \& LEVINSON entendem dizer o oposto do que se quer dizer, ou minimizar uma asserção, ao mesmo tempo que são oferecidas indicações de que o significado a ser entendido não é o literal. Tais indicações podem ser prosódicas, gestuais ou simplesmente contextuais, baseadas nos conhecimentos token e type comuns aos participantes. No exemplo a seguir, o falante responde da seguinte maneira a uma sugestão do interlocutor, sobre a possibilidade de o parlamento alemão estar condenado à impotência:

\footnotetext{
${ }^{18}$ Sobre conhecimento type e token veja MEIRELES/BLÜHDORN 1997: sobre os conceitos de type e token veja LYONS 1978 e SCHWARZ 1992
} 
Das hätte mir noch gefehlt! (COA11) (= É só o que me faltava!)

A entonação deixa claro que $\mathrm{o}$ falante não estava realmente desejando aquilo, ou seja, "que aquilo lhe faltava". Assim, entende-se que ele pretende expressar exatamente o contrário, rejeitando o quadro proposto pelo interlocutor.

\subsubsection{Seja vago}

Com esta estratégia, o falante faz com que sua intenção comunicativa, neste caso, a Dissensão, seja mal definida. Muitas vezes, o contexto é forte o bastante para deixar poucas dúvidas quanto à intenção do falante, mas a simples formulação vaga é suficiente para preservar, ao menos pró forma, a Face do nterlocutor. Um caso de uso dessa estratégia no corpus deste deste trabalho é a seguinte ocorrência:

[...] und unglückliche Verhaltensweise oder falsche Reaktionen, die auch den Irrtum mit einschließt, ist etwas ganz anderes als das, was mir wirklich vorgeworfen worden ist. (COA30)

Neste exemplo, referindo-se a acusações sobre seu comportamento em uma situação anterior, o falante evita colocar explicitamente aquilo que os demais afirmam sobre o seu comportamento e que ele considera errado ou mesmo falso. Assim, deixa aos interlocutores a tarefa de identificar aquilo que "realmente lhe foi imputado" e que, na sua interpretação, é "algo muito diferente" do que realmente aconteceu, ou seja, apenas uma reação infeliz da sua parte.

\subsubsection{Exagere}

Aumentar fatos de modo que os mesmos atinjam a todos, incluindo o falante e o interlocutor, pode ajudar a deixar menos explícito o objeto da Dissensão, como no exemplo abaixo a seguir: quando um interlocutor sugere que se arrecade um marco (moeda alemã) extra para a segurança nas estradas. o falante expressa-se da seguinte maneira: 
[...] ein Bataillon von Leuten ttt - lacht- ttt von Leuten, die das nun verwalten und ordnen wollen. Und am Schluß haben wir zu den vielen Institutionen noch eine mehr. $+g+$ und ich fürchte diese diese ganze Sache auch wie mit dem Föderalismus... (TRA10)

Aludindo a um "batalhão de gente" que seria necessário para administrar essa taxa, o falante maximiza os aspectos negativos da sugestão do interlocutor, evidenciando sua Dissensão.

\subsubsection{A realização lingüística de Estratégias offrecord na Dissensão}

Conforme já mencionamos no item 3.1.1, as expressões off record da Dissensão são realizadas manipulando-se o Princípio de Relevância postulado por SPERBER \& WILSON, de modo a gerar implicaturas. Para tanto, os participantes de uma interação trabalham com premissas implícitas, que devem ser indicadas pelo falante e ativadas pelo interlocutor, o qual deve recuperá-las de sua memória ou construí-las, desenvolvendo esquemas de assunções presentes em seu estoque de conhecimento (cf. SPERBER \& WILSON, 1986: 195). O falante, com base em sua experiência ou expectativas com relação ao interlocutor, pode pressupor que tais conhecimentos estejam presentes na memória deste último, de modo que o interlocutor seja capaz de seguir as indicações que lhe são fornecidas para a ativação das implicaturas. Mas quais seriam estas indicações?

Segundo SPERBER \& WILSON, qualquer sinal ostensivo de que o falante deve procurar em seu conhecimento do mundo ou da situação a relevância do que foi dito serve como tal indicação. Este tipo de pressuposições, baseadas nos conhecimentos type e token, são denominadas pressuposições pragmáticas (cf. LINKE et. al., 1991: 231ss.), como no seguinte exemplo:

Após a interlocutora ter comparado almôndegas com Klopse (uma c de hambúrger), o falante retruca:

(Frau Linau) ich würde sagen (vorsichtig) [...](ALM13)

Segundo o Princípio de Relevância, a interlocutora deve procurar, na situação comunicativa ou em seu conhecimento do mundo, razões pelas quais o falante possa ter-lhe recomendado cuidado. Desde que, na situação em que se encontram, não há qualquer indicação de perigo concreto (por exemplo, eles estão em um estúdio e não há sinal de fogo, feras ou criminosos), a interlocutora procura no pré-texto algo com o que tenha de 
se preocupar. Sendo que o falante manifestou-se logo após sua comparação entre almôndegas e Klopse, e que vorsichtig indica que se deve parar e atentar para eventos ou objetos "anormais" que possam prejudicá-la, a interlocutora pode derivar a implicatura de que o rumo de seus pensamentos é considerado "errado" pelo falante.

Porém, existem também pressuposições que são ativadas diretamente por meio de sinais lingüísticos (cf. LINKE et. al, 1991: 232ss.). Tais pressuposições podem ser de cunho referencial, no qual o falante, através do artigo definido e/ou de determinados atributos, apresenta um conteúdo de forma a implicar que ele existe ou é conhecido pelo falante:

ich möchte mich dagegen wehren, daß Frau Dr. Runge und auch meine beide Vorrednerinnen diese Leute in England, die auf Bestellung ungeborene Kinder abmurksen, als Arzte bezeichnen...(ABO28)

No exemplo acima, a falante caracteriza e qualifica um certo grupo de pessoas através do pronome definido diese ("estas") e dos atributos in England ("na Inglaterra") e die auf Bestellung ungeborene Kinder abmurksen ("que, por encomenda, liqüidam crianças não-nascidas"). Até o momento havia-se apenas comentado que, na Inglaterra, o aborto era legalmente permitido. A falante apresenta, então, um certo grupo de pessoas como existente e conhecido dos demais interlocutores, para depois expressar sua desaprovação para com os procedimentos dos mesmos.

Essa desaprovação é expressa utilizando-se um outro tipo de pressuposição ligada ao signo lingüístico, as pressuposições semânticas (cf. LINKE et al., 1991: 231ss.). Ao utilizar a palavra abmurksen, que significa "matar" e está registrada no dicionário como salopp, ou seja, pertencente a um registro da fala menos formal e menos compatível com o nível social dos participantes da discussão, a falante evoca nos interlocutores conotações ligadas a atividades irregulares, possivelmente escusas, expressando seu desprezo por tal grupo de pessoas.

As possibilidades de realização lingüística da Dissensão off record são portanto, muito variadas e dependentes da manipulação de pressuposições pragmáticas ou ligadas ao signo lingüístico. Assim sendo, as ocorrências do uso de estratégias off record, listadas no Anexo, lá estão explicadas caso a caso. 


\subsubsection{A Dissensão direta}

As expressões diretas da Dissensão compreendem as ocorrências nas quais a discordância do falante para com o que ele julga ser a representação mental do interlocutor é sinalizada diretamente, da seguinte maneira:

1) através de elementos lexicais que implicam a idéia de discordância - geralmente elementos sintáticos negativos, mas também partículas e mesmo substantivos, conforme detalhado no item 3.2.2.1;

2) através da apresentação, por parte do falante, de uma proposição contrária ou argumentos que se opõem àquela apresentada pelo interlocutor.

Entendemos "proposição contrária" como aquela que contém uma atribuição de valores referentes a determinadas propriedades que, dentro de escala contínua entre pólos opostos, posiciona-se mais próxima ao pólo da escala mais afastado com relação ao ponto atribuído pelo interlocutor em sua contribuição. Como exemplo, podemos citar a seguinte ocorrência:

A: wir planen gar nicht nebeneinander her (EXT2)

["nós não fazemos planejamentos redundantes']

B: (o ja) Internationen das Goethehaus und die $+\mathrm{g}+D A A D$ die planen wahn:sinnig nebeneinander her.[...] (EXT3)

['ah sim, Internationes, Goethehaus e o DAAD fazem planejamentos redundantes loucamente']

na qual o falante apresenta uma interpretação alternativa à do interlocutor, posicionada mais próxima ao pólo contrário da escala de freqüência de ocorrência do predicado "planejar de modo redundante" naquela situação, que poderia ser assim representada:

\section{"planejar de modo redundante":}

nunca - por vezes - muitas vezes - freqüentemente - na maioria das vezes - sempre 
A terceira possibilidade de realização direta da Dissensão, através da apresentação de argumentos contrários, corresponde às técnicas que SPRANZ-FOGASY denomina afirmação alternativa e fundamentação. Conforme apresentado no item 1.1.1.3, estas técnicas consistem, respectivamente, em apresentar uma proposição que contém uma outra interpretação, incompatível com a validade da afirmação do interlocutor e que a exclui (o exemplo citado é: $A$ : a casa é azul - B: $a$ casa é verde: como a casa - geralmente - só pode ter uma cor, entende-se que o falante $B$ discorda do interlocutor $A$ ) ou conteúdos que, através de uma relação causal, devem fazer o conteúdo em debate parecer apenas possível ou impossível (por exemplo, $A$ : ontem vi Maria no clube - B: Maria está na Europa - como Maria não pode estar na Europa e no clube, que não fica na Europa, o interlocutor pode deduzir que o falante não acredita que ele a tenha visto lá no dia anterior).

$\mathrm{Na}$ realidade, a Dissensão realizada pela apresentação de uma proposição contrária é um caso de implicatura, como fica claro ao refazermos os passos que levam à idéia de discordância. Contudo, é necessário lembrar que, enquanto as estratégias off record só se realizam através da criação de implicaturas, nem todos os casos de implicatura devem necessariamente enquadrar-se como exemplos de Dissensão off record. Para BROWN \& LEVINSON, cuja definição adotamos neste trabalho, para a realização de um FTA off record, o falante deve fazê-lo de modo que não se possa atribuir-lhe claramente apenas uma intenção comunicativa. Em contextos como os citados acima, a derivação de implicaturas como causa- efeito e oposição é praticamente obrigatória e o falante dificilmente pode eximir-se da Dissensão. O caso apresentado acima, no qual os falantes especulam sobre o paradeiro de Maria, a contribuição de B seria imediatamente entendida como uma Dissensão de sua parte. As únicas possibilidades de eximir-se da intenção de discordar de $A$ seriam a alegação de um gracejo ou de que $B$ não estava realmente reagindo à contribuição de $A$, mas apenas externando em voz alta pensamentos que lhe ocorreram quando Maria foi mencionada, o que em alemão é freqüentemente denominado aneinander vorbei reden (cada pessoa fala de um assunto diferente, embora pensem estar dialogando).

No entanto, tais alegações seriam pouco convincentes no tipo de interação que compõe o corpus desta pesquisa. Em Discussões na mídia eletrônica, espera-se que os participantes mantenham-se envolvidos numa interação centrada (MARCUSCHI, 1986: 15) e, assim, que as contribuições de 
um falante digam respeito às últimas contribuições do(s) interlocutor(es) ou ao tema em discussão no momento. Assim, exemplos de afirmação contrária e exemplo contrário, mesmo sem elementos lexicais que sinalizem explicitamente as relações de oposição, são consideradas aqui Dissensões diretas, pelo fato de o falante não procurar, através de tal formulação, meios de escamotear sua intenção de discordar do interlocutor.

\subsubsection{A realização lingüística da Dissensão direta}

$\mathrm{O}$ fato de as estratégias off record de Trabalho da Face terem sido as menos utilizadas (como estratégia única) para a expressão de Dissensão no corpus parece confirmar a observação de SPRANZ-FOGASY mencionada no item 1.1.1.3, de que talvez "a idéia cotidiana de 'contradição' precisa de manifestações marcantes e claras, para as quais o uso de sinais de negação pode ser paradigmático" (SPRANZ-FOGASY, 1986: 56). A grande maioria das expressões de Dissensão do corpus apresenta ao menos um sinal lingüístico que marca ou introduz diretamente a Dissensão.

A maior parte desse sinais lingüísticos são elementos que aqui denominamos semanticamente negativos. Tais elementos, pertencentes a diversas classes gramaticais, podem indicar a restrição ou não aprovação do falante frente aos conteúdos e atitudes apresentados pelo interlocutor, explicitando sua Dissensão.

A organização de elementos lexicais e sintáticos de acordo com seu conteúdo semântico é proposta, por exemplo, por SOMMERFELDT et al. (1991), os quais introduzem a noção de campo gramático-semântico (grammatisch-semantisches Feld), baseada em uma abordagem semânticofuncional da linguagem:

Quando se parte do pressuposto de que o sistema da linguagem consiste de unidades bilaterais, as quais possuem um plano de expressão e outro do significado (semântica), pode-se agrupar tais elementos tanto pela expressão quanto pelo significado. [...] O significado lexical consiste de unidades de significado/semas. Com base em semas comuns pode-se definir campos de palavras. [...] O elemento constitutivo de um campo gramático-semântico é, portanto, um sema ou um feixe de semas. A um desses campos pertencem não somente meios gramaticais (p.ex.: morfemas, Fügewörter), mas também meios lexicais. Tais campos, que consistem de meios gramaticais e lexicais e que são conscientemente dirigidos a atividades comunicativas, chamamos campos 
semântico-funcionais. [...]. Finalmente, note-se que os elementos de um campo atuam conjuntamente na atividade lingüística, influenciando uns aos outros. Tudo isto torna necessária uma abordagem integral do sistema lingüístico (cf. SOMMERFELD et al., 1991: $5 \mathrm{~s}.)^{19}$.

Considerando-se a acepção de SOMMERFELDT et al., a Dissensão engloba diversos campos semântico-funcionais, como o campo da negação, especificamente, e os micro-campos concessivo e restritivo, podendo realizar-se explicitamente através de diversos elementos sintáticos e lexicais. Apresentamos, a seguir, os elementos utilizados para expressar diretamente a Dissensão no corpus da pesquisa.

\section{i) Elementos sintáticos negativos}

O conceito de negação em nível sintático e de elementos sintáticos negativos é o tema de diversos estudos e compêndios de gramática em alemão. Em um estudo anterior (MEIRELES, 1991) resenhamos alguns desses trabalhos e definimos, para o alemão, um grupo de elementos sintáticos com papel semântico de negativadores a partir da abordagem de Heringer (1989: 192). Tais elementos são nein, nicht, kein, keinerlei, keineswegs, keinesfalls (auf keinem Fall), nie(mals), niemand, nirgendwo wohin, ohne, nur, nimmer, ohne zu, ohne daß, anstatt zu, weder... noch, e vários deles ocorrem no corpus com a função de sinalizar a expressão de uma Dissensão. Os elementos listados acima pertencem, na gramática tradicional, a diversas categorias (como advérbio/Partikel, pronome, preposição, conjunção). No entanto, todos têm em comum a propriedade de inverter o valor de verdade de uma proposição ou de excluir completamente um elemento de uma proposição. Em virtude dessa propriedade, são geralmente agrupados em separado, como elementos negativadores, pela maioria dos estudiosos do assunto em alemão, com os quais concordamos. A

\footnotetext{
${ }^{19}$ Wenn man davon ausgeht, daß das Sprachsystem aus bilateralen Einheiten besteht, die über eine Seite der Form und eine Seite der Bedeutung (Semantik) verfügen, kann eine Gliederung der Elemente sowohl bei der Form als auch hei der Bedeutung ansetzen. [...] Die lexische Wortbedeutung besteht aus Bedeutungselementen/Semen. Auf Grund gemeinsamer Seme lassen sich lexische Wortfelder konstituieren. [...] Konstituierendes Element eines grammatisch-semantischen Feldes ist also ein Sem/Sembündel. Zu einem Feld gehören nicht nur grammatische Mittel (z.B. Morpheme, Fügewörter), sondern auch lexische Mittel. Solche Felder, die aus grammatischen und aus lexischen Mitteln bestehen und die bewußt auf kommunikative Tãtigkeit gerichtet sind, nennen wir funktional-semantische Felder. [...] Schließlich sei darauf verwiesen, daß die Elemente eines Feldes in der sprachlichen Tätigkeit zusammenwirken, einander beeinflussen. Das alles macht eine integrale Betrachtung desSprachsystems nötig. (SOMMERFELDT et al., 1991: 5s.)
} 
denominação "sintáticos" justifica-se pelo fato de tais elementos atuarem no nível da proposição, ou seja, sua principal característica é a atuação em nível sintático.

- NEIN

A DUDEN Grammatik considera nein como equivalente a uma sentença negativa (cf. DUDEN, 1984: 641). Por outro lado, WEINRICH, de um ponto de vista mais pragmático, considera nein corno um sinal comunicativo do falante, com o qual ele detém e/ou rejeita uma contribuição do interlocutor à interação (cf. WEINRICH, 1976: 81).

SPRANZ-FOGASY observa que nein é a forma mais freqüente, em seu corpus, de sinalização da estratégia que ele denomina Reclamação, a qual consite em:

[...] elementos do enunciado que, quer por sua posição, quer por suas propriedades semânticas, qualidades fonéticas e/ou características entonatórias, indicam a rejeição da interpretação do conteúdo proposicional apresentada pelo interlocutor [...]. A Reclamação é principalmente um meio rápido e claro de interromper o interlocutor e/ou tomar-lhe o turno. Com isto, o fato de que o oponente tem uma outra perspectiva do assunto é marcado quase "em cima do lance' (cf. SPRANZ-FOGASY, 1986: 33s.) ${ }^{20}$

Também em nosso corpus, a expressão nein tem principalmente essa função de sinalizar a Dissensão, sozinha ou posteriormente desenvolvida, utilizando-se de outros elementos semanticamente negativos e/ou de Estratégias de Trabalho da Face.

No corpus deste trabalho, encontramos 45 ocorrências do uso de nein como sinalizador da Dissensão, sendo que em apenas oito delas aparece como único responsável pela expressão da Dissensão.

\section{- NICHT E KEIN}

A: contrário de nein, que é entendido como equivalente a uma oração negativa, as expressões nicht e kein funcionam como operadores em nível proposicional. O uso de um ou de outro elemento depende de várias

${ }^{20}$ [...] Äußerungselemente, die qua Sequenzposition, semantischen Eigenschaften, phonetischen Qualitäten und/oder intonatorischen Merkmalen die Sachverhaltsdarstellung eines Gegenübers zurückweisen. [...] Die 'Reklamation' ist vor allem ein Mittel, sehr schnell und deutlich an den Beitrag des Gegenübers anzuschließen bzw. ihn zu unterbrechen. Damit wird quasi "vor Ort" markiert, daß der Opponent eine amdere Perspektive auf den Sachverhalt hat. (SPRANZ-FOGASY, 1986:33s) 
características dos elementos lingüísticos da proposição sobre a qual operam, e o estabelecimento de regras para seu uso costuma ocupar um lugar significativo e extenso nos estudos da negação em alemão. Para este trabalho, tais questões não são relevantes, pois que ambos atuam da mesma maneira, invertendo o valor de verdade de uma proposição atribuída ao interlocutor ou sinalizando, em formulações específicas, a não concordância do falante com a representação de conteúdos que ele atribui ao interlocutor. Como exemplos dessas duas possibilidades de utilização de nicht e kein como sinalizadores de Dissensões, podemos citar as seguintes ocorrências do corpus:

(ja) wir haben jetzt nur das: negative Bild mitgezeigt, daß da dem gegenüber sehr positive Beispiele gestellt werden können, ist ganz klar, aber leider $+g+$ ist auch ein derartiger Saal eben keine absolute Ausnahme. (MEN3)

ich darf zunächst sagen (Herr Heizler) sie sagen wir stünden vor schweren Auseinandersetzungen innerhalb der SDP. das ist nicht richtig. [...] (COAI)

No corpus da pesquisa, constatamos 11 ocorrências do uso de kein e 48 do uso de nicht como elementos responsáveis pela realização da Dissensão.

\section{- Outros elementos sintáticos negativos}

Dentre os demais elementos sintáticos negativos citados ao início deste item, encontramos no corpus ocorrências de keinesfalls, keineswegs, auf keinem Fall, niemand e nichts, sinalizando diretamente a Dissensão, como nos exemplos:

die Tatsache [...] daß verhältnismäßig wenig $+g+$ derartiger Straftaten zur Anzeige und Aburteilung kommen, macht keineswegs die Strafvorschrift unnötig. (ABO14)

und zweitens möchte ich ihnen entgegnen (Herrn Müller-Emmert) die neuen biologischen Erkenntnisse sind doch keinesfalls am Ende... (ABO18)

[Ärzte fühlen sich in dieser Beziehung ihrem hypokratischen Eid verpflichtet] da muß ich sie unterbrechen (Kollegin). Hippokrates hat davon nichts gesagt (ja?). [...] (ABO26)

(also) so schön und so so sinnreich und so (fast möcht ich sagen) so innig diese Deutung von Herrn Lenz ist, so entspricht sie doch keineswegs der kulinarischen Bestimmung dieses Nahrungsmittels... (ALM18) 
(wissen sie) da wiederholen sie (also) niemand macht hat das. mit Hammelkeulen hat man nie Wettbewerbe gemacht, sondem da hat man also... (nich?) (ALM27)

[Eindruck, man solle eine Stunde lang Gebrauchtexte üben] es wird nur das Formale angesprochen $+g+$ in welcher Form. aber es wird auf keinen Fall verlangt, daß man das eine Stunde lang macht, sondem, daß es un:ter anderem und daß die anderen kritisch sich dazu äußern... (ALEI 4)

\section{ii) Partículas modais}

Até o desenvolvimento da vertente pragmática da lingüística, a partir da década de sessenta, as partículas modais em alemão (Abtönungspartikeln) eram desprezadas pelas gramáticas tradicionais, que se apoiavam principalmente na língua escrita e em exemplos construídos para ilustrar os fenômenos estudados. Quando os estudos lingüísticos se voltaram mais fortemente à comunicação oral e a estudos empíricos baseados em materiais autênticos, as partículas cresceram em importância, sendo, atualmente, um fértil campo de pesquisas, principalmente nas áreas da pragmática, da tradução e da lingüística contrastiva.

Mesmo a denominação Abtönungspartikeln ou "partículas modais" é controversa. Alguns dicionários consideram como Partikel quaisquer palavras não-flexionáveis, incluindo aí preposições, conjunções e advérbios. A esta definição, o DUDEN acrescenta uma outra: "palavra não acentuada, sem função sintática [e sem significado próprio], que modifica o significado de uma asserção" (cf. DUDEN, 1983: 927). HELBIG, em seu Lexikon deutscher Partikeln, adota a mesma definição, apenas não fazendo menção ao problema de terem ou não um significado próprio (cf. HeLBIG, 1990, 19ss):

Neste item de nossa pesquisa, abordaremos apenas aquelas expressões classificadas por HELBIG como Abtönungs- ou Modalpartikeln e que têm como característica principal o fato de expressarem a atitude do falante frente ao seu enunciado (cf. HelBiG, 1990: 32), de onde a denominação Modalpartikeln. 
O termo que utilizamos em português, "partículas modais", é uma tradução literal, pois que, em português, não há nada que corresponda ao conceito de partícula na acepção do alemão. Visto que o Dicionário de Lingüística de DuBOIS et al. define os termos "modalização" como "a marca dada pelo sujeito a seu enunciado" e "modalizador" como "os meios pelos pelos quais um falante manifesta o modo como ele considera seu próprio enunciado" (cf DuBOIS et. al., 1997: 414s.), o conceito de "modal" em português pode ser considerado correspondente àquele implícito no termo Modalpartikel. fazendo de "partícula modal" uma tradução aceitável.

No corpus do trabalho, encontram-se 72 ocorrências do uso da partícula modal doch, muitas das quais junto a elementos sintáticos negativos, reforçando-os. No Lexikon deutscher Partikeln, uma das possibilidades de seu uso é assim apresentada:

[...] em sentenças afirmativas, não acentuado; refere-se a um ato de fala anterior (lance anterior) e produz entre ele e a asserção comentada com doch uma leve contradição; por um lado, assume funções de conexão textual, por outro, traz uma reação não esperada pelo falante anterior, pois o lance anterior é, assim, criticado ou rejeitado. Ilocutivamente, trata-se de uma rejeição (por exemplo, das premissas para a realização de uma ordem emitida no lance anterior), de uma repreensão, uma contra-repreensão ou uma justificativa (=aber). Juntamente com os aspectos da coesão textual e da conexão anafórica encontra-se freqüentemente ligada uma função de justificativa (cf. HeLBIG, 1990: 112). ${ }^{21}$

Da mesma maneira que nein, doch pode, por si só, expressar uma Dissensão. Contudo, isto ocorre em apenas 3 das 72 ocorrências de doch como sinal de Dissensão no corpus da pesquisa.

\section{iii) Conjunções}

HELBIG considera que existe uma partícula modal aber e uma conjunção homônima, e que ambas têm em comum o fato de unirem duas proposições antagônicas, sinalizando a discrepância entre ambas, ou, ainda,

\footnotetext{
${ }^{21}$ [...] in Aussagesätzen: unbetont. Bezieht sich reaktiv auf vorangegangenen Sprechakt (Vorgängerzug) und stellt zwischen ihm und der durch doch kommentierten Aussage einen leichten Widerspruch her; wirkt einerseits konversationskonnektiv, enthãlt andererseits eine vom vorangehenden Sprecher nicht eine vom vorangehenden Sprecher nicht gewünschte Reaktion, da Vorgängerzug kritisiert oder zurückgewiesen wird. Illokutiv handelt es sich um eine Zurückweisung (z..B. der Voraussetzung für die Erfüllung einer im Vorgängerzug ausgesprochenen Aufforderung), um einen Vorwurf bzw. eine Rechtfertigung (=aber). Mit Textverknüpfung und Rückwärtskonnektion ist oft begründende Funknon verbunden. (HELBIG. 1990:112)
} 
entre acontecimentos esperados e observados. Observa ainda que, em alguns contextos é difícil traçar a fronteira entre conjunção e partícula" (cf. Helbig, 1990: 81).

ROSENGREN (1984), examinando aber como indicador de contradição, analissa exemplos de seu uso por um falante (B) com a finalidade de tomar posição frente a um enunciado do interlocutor (A) e conclui que o falante, através do uso de aber (freqüentemente complementado pelas partículas ja, doch e/ou uma entonação específica), rejeita a ilocução pretendida pelo interlocutor na medida em que questiona: a) a sua pretensão de verdade ou a adequação da sua asserção, ou b) a adequação de sua ilocução, referindose, assim, àquilo que $\mathrm{A}$ afirma ou àquilo que $\mathrm{A}$ faz (comunicativamente) (cf. ROSENGREN 1984:230).

No corpus, encontram-se 129 ocorrências do uso de aber, fazendo deste elemento um dos mais importantes sinalizadores de Dissensão. Ao contrário de nein (na acepção de HELBIG, também uma partícula), aber não pode, por si só, expressar uma Dissensão, mas sim, sinaliza ao interlocutor que o falante discorda dele e que vai desenvolver sua expressão da Dissensão.

\section{- $\quad$ OBWOHL}

Na DUDEN GRAMMATIK (1984, 379), obwohl consta como uma conjunção concessiva; em SOMMERFELDT et al. (1991: 56), é apresentado, dentro do campo semântico "causa-efeito", como um exemplo de expressão do micro-campo "concessivo", o qual tem como características "causa marcada, insuficiente". Assim, obwohl introduziria uma razão contrária ao conteúdo apresentado na outra oração, a qual, porém, seria insuficiente para evitá-lo, como no único exemplo do corpus da pesquisa:

\section{obwohl wir hierjetzt nicht lauter Zitate ... möchten (MEN5)}

Nesta ocorrência, o falante expressa sua contrariedade frente à intenção do interlocutor, que pretende fazer uma citação, ao dizer: "embora nós não quiséssemos ouvir agora uma batelada de citações". Através da formulação com obwohl, o bloqueio não é apresentado como definitivo, permitindo ao interlocutor decidir se o acata ou não. 


\section{iv) Verbos}

Seguindo o conceito de campos semântico-funcionais, alguns verbos podem, de acordo com a sua carga semântica, apresentar um significado negativo, sem a presença de outros elementos negativos na frase (cf. Sommerfeld et al., 1991: 94). Tais verbos também são apropriados para expressar a Dissensão. Entre os casos presentes no corpus, encontram-se os seguintesexemplos:

es sieht beispielweise eindeutig fest (insofern da muß ich ihnen (Frau Dr. Brandenburg) widersprechen), daß $+g+$ der Begriff Leibsfrucht im Sinne des Gesetzes 1871 so verstanden worden ist, wie sie es sagen, nämlich Befruchtung... (ABO17)

$+g+i c h$ möchte nicht bestreiten, daß es Ansätze gibt, aber ich mõchte etwas bestreiten, daß es derzeit unter den 59 in der BRD bestehenden Landeskrankenhausern ei:nes gibt, was sich mit einer ganzen Reihe zur Zeit in England bestehender vergleichen ließe.[...] (MEN11)

(ja) aber ich muß $d a+g$ - dem eigentlich entgegenhalten, $+g+d a \beta d a s$ natürlich Ergebnisse sind, die durch Befragung $+g+$ von $+g+$ Personnen gewonnen wurden, die bereits einen sehr langen Sozialisationsprozeß hinter sich haben. [...] (SEX5)

Dependendo do contexto, verbos que normalmente não apresentam um sentido primariamente negativo podem expressar a Dissensão por implicarem que a contribuição do interlocutor é incorreta ou incompleta, como nas ocorrências:

[und zwar würde ich sagen, die Frau steht heute davor, ihre Befreiung sich zu erringen...] (liebe liebe gnädige Frau) sie mißverstehen mich ja völlig [...] (ABO21)

[Man könnte mit Bouletten Diskus spielen] das das bezweifle ich. (nein nein) das bezweifle ich. (ALM24)

(ja) entschuldigen sie aber erst muß ich sie mal ein kleines bißchen berichtigen. (RDA2) 


\section{v) Substantivos}

Do mesmo modo que verbos, também substantivos podem apresentar um traço semântico de discordância, ao deter a interação (bloqueio) ou ao implicar a interpretação, por parte do falante, de que a contribuição do interlocutor é inadequada, reprovável ou enganosa, como em:

Widerspruch $+g+$ wenn ich $+g+$ (Entschuldigung) wenn ich sage ich glaube doch, daß hier nach den neusten etymologischen Forschungen ein Irrtum vorliegt $+g+i$ ch glaube nicht $+g+d a \beta$ die Herkunft [...] sondern daß... ALM10)

darf ich mal den den den Gegensatz rauskehren? Es gibt já auch einen Nebenbuhler (ALM11)

Em alguns casos, a Dissensão é expressa menos pelos traços semânticos do substantivo em si, mas principalmente pela atuação do mesmo em um contexto específico. Por exemplo, o substantivo Schwierigkeit (dificuldade) não expressa necessariamente uma discordância, como em:

- Er redet sehr schnell. Nicht alle vestehen ihn. (ele fala muito rápido. Nem todos o entendem.)

- Ja, viele haben da Schwierigkeiten.

(sim, muitos têm dificuldades.)

porém, assume esse papel no seguinte exemplo:

(ja) es besteht halt bloß die Schwierigkeit dabei, daft man mit $+g+$ (sozusagen) organisatorischen Kriterien wie Rückkoppelung eigentlich gar nichts erledigt... (ALE16)

\section{vi) Advérbios}

- TROTZDEM

Assim como obwohl é considerado uma conjunção concessiva, trotzdem é apresentado na DUDEN GRAMMATIK (1984: 352) como um advérbio concessivo, que apresenta uma razão contrária a um conteúdo, porém sem influência sobre ele. Em nota de rodapé à página 379 da mesma obra, observa-se que pode também ser utilizado como conjunção 
concessiva, embora tal uso seja desaconselhado na língua-padrão. Assim, como advérbio ou como conjunção, também integra o microcampo concessivo de SOMMERFELDT et. al. (1991: 56), embora não haja qualquer exemplo explícito na obra. No exemplo a seguir, trotzdem marca a Dissensão por parte da falante, quando ela afirma que o fato de mulheres terem filhos não é empecilho ao desenvolvimento de sua personalidade:

das ist ja trotzdem möglich die Freiheit der Entfaltung der Persönlichkeit. wir haben ja andere Mittel um die Persönlichkeit frei entfalten zu können... (ABO12)

\section{- $\quad K A U M$}

À pagina 351, a DUDEN GRAMMATIK atribui a kaum (assim como a nicht) o status de "advérbio modal" (Modaladverb) pois que, através de tais advérbios, "o falante/autor expressa como ele avalia uma afirmação, em que grau, na sua opinião, uma afirmação é válida ou adequada." Em uma escala estabelecida pelos autores entre os extremos ja e nein, kaum é apontado como o elemento mais próximo ao pólo negativo. Desse modo, em relação à negação total, kaum representa uma certa atenuação.

No corpus da pesquisa, temos apenas a seguinte ocorrência do uso de kaum para expressar uma Dissensão:

(OP) [...] ich weiß nicht, ob das immer etwas Gutes ist (nich?) ich will man kann doch wohl kaum als gut bezeichnen, wenn im ganz bestimmten Ländern eben noch sehr rückschrittliche Tendenzen herrschen. (DEU6)

\section{- DAGEGEN}

O advérbio dagegen é citado como pertencente ao micro-campo denominado Gegensatz, ou seja, contraste, antagonismo (cf. SOMMERFELDT 1991: 73 e 77), prestando-se também, portanto, à expressão da Dissensão. No corpus do trabalho encontramos apenas o seguinte exemplo:

(also) $+g+$ auch dagegen bin ich, da $\beta+g+$ die jungen Fahrer von vornherein mit einem Zuschlag belastet werden. Es ist doch bei uns so, daß ohnehin: derjenige, der einen Unfall $+g+$ hat [...] er muß dann eine höhere Prämie zahlen [...] aber ihn von vornherein schlechl einzustufen das wäre verkehrt...(TRA63) 


\section{vii) Adjetivos}

Vários adjetivos apresentam, assim como no caso dos substantivos e advérbios, traços semânticos que implicam Dissensão ao indicar uma avaliação da contribuição do interlocutor como inadequada, reprovável ou enganosa. Freqüentemente, o uso do adjetivo em um contexto específico é o principal agente de tal interpretação. Entre as ocorrências de seu uso no corpus para a expressão da Dissensão estão os exemplos a seguir:

ich glaube doch, daß es widersinnig ist, wenn $+\mathrm{g}+$ denn die Justiz die Frauen [...] verfolgen würde, müßte man mit zwei bis fünf Millionen Abtreibungsprozessen rechnen. das heißt die Justiz wäre vällig lahmgelegt. $+g+$ in der Tat haben zum Beispiel 1969 die Behörden nur in insgesamt 1005 Fällen $+g+$ ermittelt. das heißt die Bestrafung ist also völlig willkürlich. das ist eine groteske Angelegenheit... (ABO15)

(na) ich mein den Faschismus auszusparen wär ja völlig falsch (nich?) (ALE 11)

mir ist das alles mir ist die Definition zu abrupt und mir ist auch die Interpretation von Herrn Honig zu abrupt. [...] Boulette ist nicht nur eine Fleischspeise. Boulette ist nicht nur dieses [...], sondern ich glaube es gibt viele Möglichkeiten von Bouletten... (ALM9)

\section{viii) Proposição contrária/argumentos contrários}

Conforme apontamos no item 3.2.2, por vezes a Dissensão é expressa apresentando-se afirmações que conflitam com a contribuição do interlocutor, criando o efeito de Dissensão. Os casos de Dissensão pela apresentação de proposição contrária ocorrem geralmente quando o interlocutor apresenta um conteúdo através de uma formulação sintaticamente negativada, como no exemplo apresentado anteriormente, no qual o falante discorda do interlocutor, que havia afirmado não haver casos de planejamentos redundantes:

(o ja) Inter Nationes das Goethehaus und die $+g+$ DAAD die planen wahn:sinnig nebeneinander her. das sieht man dauernd in der Praxis. (KUL3)

ou neste outro caso, onde o falante refuta a afirmação do interlocutor, de que este não teria escrito relatórios para um determinado jornal, através da apresentação da data na qual tal relatório teria sido publicado: 
[es hat nie ein Bericht von mir im Völkischen Beobachter gestanden] sechsten Juli 1941 (Herr Nannen) (KRI64)

Por vezes, o falante apresenta exemplos que contradizem um conteúdo apresentado pelo interlocutor, derivando a seguinte inferência: se há casos nos quais ele não se aplica, tal conteúdo não está (completamente) correto e, portanto, se o falante apresenta tais exemplos, ele discorda do interlocutor. Também nestes casos, o falante não tenta eximir-se da responsabilidade pela Dissensão, razão pela qual tais casos são considerados exemplos de Dissensão direta. Entre as ocorrências do corpus, destacamos ilustrativamente os seguintes exemplos: no primeiro, o falante responde à afirmação do interlocutor de que não se construiriam mais grandes hospitais psiquiátricos na RFA; no segundo, o falante responde ao interlocutor, que dissera que os responsáveis pelo trabalho cultural no exterior deveriam reunir-se para discutir seus problemas; no terceiro, o falante contesta o interlocutor, que havia afirmado que moças teriam maior dificuldades com a vida sexual que rapazes:

wenn das so sein sollte, wie sie sagen, wieso kann es dann kommen, daß man jetzt in Hirsau baut ein Krankenhaus mit tansend Betten, was den $+g+$ Vorstellungen der Weltgesundheitsorganisation [...] widerspricht?...(GEI8)

wir haben jetzt wir haben jetzt grade in London eine eine Regionalkonferenz gehabt [...] alle diejenigen, die nun einerseits in Großbritannien für die praktische Arbeit $+g+$ verantwortlich sind und dann diejenigen, die die Richtlinien bestimmen [...] (KUL6)

insofern als $+g+$ wenn ich die Untersuchungsergebnisse der beiden Hamburger Sexualwissenschaftler Volkmar Sigusch und Gunther Schmidt richtig verstanden habe, dann geht aus den Fragen an bis zu 17 Jahre alten Mädchen und Jungen eindeutig hervor, daß beide Geschlechter mit geringen Prozentunterschieden [...] daß also beide Jungen wie Mädchen der Ansicht sind, $+g+$ beide Geschlechter hätten genau das gleiche sexuelle Bedürfnis nach dem anderen Partner. (SEX4) 


\section{Quadro sinótico da realização lingüística da Dissensão direta}

\begin{tabular}{|c|c|}
\hline Elementos sintáticos negativos & $\begin{array}{l}\text { nein, nicht, kein, nichts, niemand, } \\
\text { keineswegs, keinesfalls, auf keinen } \\
\text { Fall }\end{array}$ \\
\hline Partículas modais & doch \\
\hline Conjunções & aber, obwohl \\
\hline Verbos & $\begin{array}{l}\text { widersprechen, entgegnen, sich } \\
\text { gegen etwas wehren, bestreiten, } \\
\text { entgegenhalten; dependentemente } \\
\text { do contexto: mißverstehen, } \\
\text { bezweifeln, berichtigen, kurz } \\
\text { greifen, vertuschen, umdrehen, } \\
\text { verfälschen, einwenden, gegen } \\
\text { etwas angehen }\end{array}$ \\
\hline Substantivos & $\begin{array}{l}\text { Widerspruch, Irrtum, Gegensatz, } \\
\text { Gegenteil, Unterschied, Einspruch, } \\
\text { Unterstellung, Unfug, Zudeckung, } \\
\text { Vorurteil, Unwahrheit, Fehler, } \\
\text { Unterschied, Gegenfrage; } \\
\text { dependentemente do contexto: } \\
\text { Verfremdung, Schwierigkeit, } \\
\text { Bedenken, Befürchtung, Mãrchen, } \\
\text { Frage }\end{array}$ \\
\hline Advérbios & trotzdem, kaum, dagegen \\
\hline Adjetivos & $\begin{array}{l}\text { widersinnig, anders, falsch, } \\
\text { verschieden; dependentemente do } \\
\text { contexto: willkürlich, gefährlich, } \\
\text { schwer, übertrieben, spektakulär, } \\
\text { grotesk, rückhaltlos, unvollständig, } \\
\text { abrupt, schlecht, schwierig, } \\
\text { unrealistisch, unbewiesen, verkehrt, } \\
\text { unerträglich }\end{array}$ \\
\hline $\begin{array}{l}\text { Afirmação contrária, argumentos } \\
\text { contrários }\end{array}$ & $\begin{array}{l}\text { formulações individuais, dependentes } \\
\text { do contexto }\end{array}$ \\
\hline
\end{tabular}




\subsubsection{Dissensão direta, sem compensação}

Segundo o esquema das Super-Estratégias de Trabalho da Face, a Dissensão pode ser realizada diretamente, com ou sem ação de compensação. Examinamos, nos itens que se seguem, cada um desses casos, conforme os resultados da análise das ocorrências.

No corpus da pesquisa, foram encontradas 42 ocorrências de Dissensão direta, sem qualquer estratégia de compensação positiva ou negativa. Tais ocorrências distribuem-se da seguinte forma pelos vários inquéritos:

\begin{tabular}{|l|c|}
\hline \multicolumn{1}{|c|}{ INQUÉRITO } & OCORRÊNCIAS \\
\hline ABORTO & 3 \\
\hline ALEMÃO & 1 \\
\hline ALMÔNDEGAS & 2 \\
\hline COALIZÃO & 3 \\
\hline EXTERIOR & 1 \\
\hline GUERRA & 25 \\
\hline MÃES & 2 \\
\hline MENTAL & 0 \\
\hline MODERADORES & 0 \\
\hline RDA & 1 \\
\hline SEXO & 0 \\
\hline TRÂNSITO & 3 \\
\hline ULBRICHT & 1 \\
\hline TOTAL & 42 \\
\hline
\end{tabular}

A opção pela expressão direta sem compensação, é a forma de expressão direta de Dissensão menos utilizada no corpus $(4,68 \%)$ o que parece confirmar a hipótese de que a Dissensão é considerada uma ameaça às Faces, devendo, portanto, ser compensada de modo a não incorrer em sanções ou causar problemas à relação entre os participantes da interação.

De acordo com BROWN \& LEVINSON, a opção por fazer o FTA diretamente e sem ação de compensação geralmente ocorre quando o falante está mais interessado em transmitir informação com o máximo de eficiência, do que em preservar as Faces. Porém, essa estratégia também pode ser utilizada para implicar que a informação transmitida é urgente ou tão importante, que a consideração pela Face pode ser deixada de lado. Outra possibilidade de uso dessa estratégia são situações nas quais o falante é tão mais poderoso socialmente 
que o interlocutor, que não é necessário considerar as necessidades de Face deste último, ou em situações nas quais a relação está tão deteriorada, que não se atenta mais ao respeito às Faces e o falante deseja ser deliberadamente rude.

Este último caso parece ser decisivo na escolha desta estratégia para a expressão da Dissensão, pois, nos inquéritos que apresentam maior concentração de ocorrências desta estratégia (GUERRA, COALIZÃO), nota-se uma crescente deterioração da interação, com os falantes passando, por vezes, a ofensas pessoais. Em outro inquérito, uma das participantes chega a reagir com ironia a uma Dissensão expressa diretamente, sinalizando o que considerou uma atitude deselegante da interlocutora:

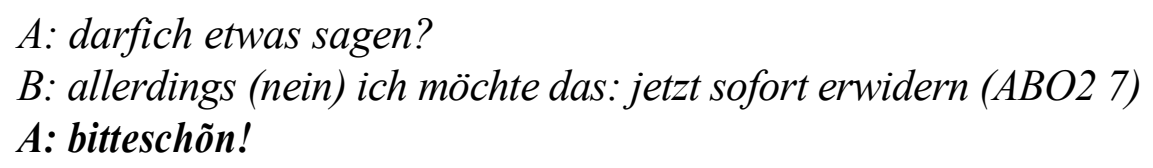

A: darfich etwas sagen?

B: allerdings (nein) ich möchte das: jetzt sofort erwidern (ABO2 7)

A: bitteschõn!

Embora se encontrem no corpus vários exemplos de expressão direta da Dissensão sem ações de compensação, a grande maioria das ocorrências de expressão direta de Dissensão é acompanhada de estratégias de compensação para um possível dano à Face. Tais ações de compensação podem basear-se nas super-estratégias de polidez positiva ou negativa, sendo possível, inclusive, a combinação de ambas para a expressão de uma Dissensão. Com base nas estratégias apontadas por BROWN \& LEVINSON, procuramos identificar as Estratégias de Compensação Positiva e Negativa utilizadas no corpus para a expressão da Dissensão, as quais são apresentadas nos itens 3.2.2.4 e 3.2.2.5.

\subsubsection{Dissensão direta com Estratégias de Compensação Positiva}

Conforme discutido no item 1.3.5.2, BROWN \& LEVINSON denominam polidez positiva àquelas estratégias que visam aproximar o falante de seu interlocutor, dando a impressão de que ambos são parte de um mesmo grupo, são iguais em seus desejos e receios e que, assim sendo, atos que potencialmente ameaçariam a Face não precisam ser temidos, pois o falante "gosta" do interlocutor e quer apenas o seu bem, mesmo que, no momento, 
esteja agindo de um modo que possa lhe parecer ameaçador. É necessário frisar que as estratégias baseadas na polidez positiva não implicam que, na realidade, o falante goste do interlocutor ou o considere como um igual. A opção por tais estratégias pode ser ditada pela cultura do grupo social ao qual os participantes pertencem, pelas particularidades da situação de comunicação ou, ainda, pelo plano traçado pelo falante para a condução da interação. Assim, não se deve estranhar que estratégias de Compensação Positiva sejam por vezes usadas em situações onde o antagonismo é patente ou mesmo, por exemplo, em insultos, pois, neste último caso, o choque entre uma estratégia de aproximação e a situação de extremo distanciamento afetivo pode inclusive amplificar o efeito do insulto. Por esse motivo, não usaremos para as estratégias formais o termo "polidez", mas sim, Compensação Positiva.

No corpus deste trabalho, foram identificados 383 usos de estratégias de Compensação Positiva para a Dissensão. O número de usos de tais estratégias não é idêntico ao de ocorrências de Dissensão apontados no início deste capítulo, pois, conforme já mencionamos, o falante pode combinar várias estratégias para uma mesma expressão de Dissensão:

\begin{tabular}{|l|c|}
\hline \multicolumn{1}{|c|}{ INQUÉRITO } & OCORRÊNCIAS \\
\hline ABORTO & 27 \\
\hline ALEMÃO & 19 \\
\hline ALMÔNDEGAS & 35 \\
\hline COALIZ̃̃O & 31 \\
\hline EXTERIOR & 10 \\
\hline GUERRA & 27 \\
\hline MÃES & 54 \\
\hline MENTAL & 24 \\
\hline MODERADORES & 10 \\
\hline RDA & 1 \\
\hline SEXO & 18 \\
\hline TRÂNSITO & 99 \\
\hline ULBRICHT & 28 \\
\hline TOTAL & 383 \\
\hline
\end{tabular}

\section{A realização lingüística de Estratégias de Compensação Positiva na Dissensão}

As estratégias de Compensação Positiva não são expressas por uma determinada categoria de elementos lingüísticos, mas sim por uma 
combinação de vários deles em um determinado contexto, a fim de obter o efeito desejado, de aproximação entre falante e interlocutor. Assim, por exemplo, a estratégia dê (ou peça) razões é realizada através da apresentação de razões para a expressão da Dissensão, as quais podem ser formuladas das mais diversas maneiras, sendo inclusive, por vezes, prefaciada por determinados meios lingüísticos, como, por exemplo, denn ou weil. Do mesmo modo, na análise das ocorrências, pudemos identificar alguns elementos que, de forma recorrente, são típicos na realização de uma Estratégia de Compensação Positiva em particular. Procuramos assim, nos itens que se referem à realização lingüística das estratégias de compensação, destacar tais elementos, o que não implica que estes sejam os únicos utilizáveis para este fim, ou que os mesmos possam ser utilizados apenas para a Estratégia de Trabalho da Face à qual estão sendo relacionados, ou mesmo somente para o Trabalho de Face.

No corpus da pesquisa, foram encontradas as seguintes Estratégias de Compensação Positiva na expressão da Dissensão:

\subsection{Evite discordância}

Como a Dissensão é um FTA em potencial, o falante procura minimizar a sua expressão, formulando-a de maneira que pareça ser menor do que é na realidade. No corpus da pesquisa, apresentaram-se duas subestratégias para a realização desta estratégia formal de Compensação:

\subsection{Concorde simbolicamente}

No corpus, as formas mais encontradas da estratégia evite discordância correspondem ao que BROWN \& LEVINSON definem como token-agreement e nós aqui denominamos "concordância simbólica". Com esta estratégia, o falante procura dar a impressão de que concorda com o interlocutor através de um pequeno sinal afirmativo ou da retomada de algum aspecto levantado pelo mesmo, para logo em seguida discordar claramente. O caso típico é uma Dissensão introduzida por "sim, mas...", na qual o "sim" inicial não significa qualquer concordância real:

(ja) (genau) aber das halte ich für einen Fehler ihrer Erziehung, daß sie sich so von vorneherein einschränken. (MAE41) 
BROWN \& LEVINSON atribuem tal tendência à concordância simbólica como uma decorrência da "regra de concordância" de Sacks (cf. BROWN \& LEVINSON, 1978: 119), pela qual a concordância é a alternativa preferida durante uma interação. Porém, conforme já exposto anteriormente no item 2.1.1.2, autores como POMERANTZ e KOTTHOFF verificaram que, em determinados contextos, tal regra parece não se aplicar tão fortemente. KOTTHOFF chega inclusive a afirmar que a não-concordância é a ação preferida em disputas, o que deveria diminuir a freqüência de uso da concordância simbólica em interações como as discussões que formam nosso corpus. No entanto, a alta incidência desta estratégia nos inquéritos aqui examinados e naqueles analisados por KOHNEN em seu estudo (resenhado no item 1.1.1.4) parece apontar para o fato de que tal não acontece. Em vista disso, ao invés de pôr em dúvida a validade das considerações de KotTHOFF, iremos procurar as raízes de tal incongruência em outras razões.

Em suas considerações sobre o gênero Discussão, Holly et al. (1986) referem-se à importância dada à discussão na cultura da RFA. O treino da argumentação em discussões é inclusive parte do currículo das escolas secundárias alemãs, conforme se pode depreender das recomendações de autores didáticos citadas pelos autores, dentre as quais encontra-se a seguinte: "As sugestões e pensamentos dos demais participantes devem, em primeiro lugar, ser examinados positivamente, antes que se apresentem razões contra os mesmos" (cf. Holly et al., 1986:22)

O repetido treino da discussão nas escolas, dentro de linhas-mestras como esta, pode levar a um tipo de "comportamento automatizado" de concordância simbólica como introdução a uma Dissensão. Assim, o uso da estratégia da concordância simbólica não configuraria sempre uma tentativa de evitar discordâncias com o interlocutor, podendo também ser utilizada agressivamente, o que é apontado por KOHNEN (1987: 169ss. e 189ss.)

Quanto ao uso agressivo da concordância simbólica e de seu valor ou não como concordância parcial, talvez fosse mais adequado re-alocar os casos de realização desta estratégia através de $j a$, aber... como mais um exemplo da estratégia de Compensação Negativa utilize formas convencionalizadas, a qual é detalhada no item 3.2.2.5.1. Devido ao seu uso automático como introdução a uma discordância, esta forma da concordância simbólica já teria perdido seu valor como tentativa de evitar a discordância e ja, aber teria se consagrado como uma alternativa convencional, indireta e menos agressiva ao simples "não". Tal consideração 
nos parece bastante razoável no que se refere à maioria dos casos de concordância simbólica introduzida pela "fórmula" ja, aber... Porém, ainda se encontram no corpus exemplos nos quais parece haver uma preocupação sincera do falante em tentar concordar ao menos em parte com o interlocutor, aproximando-se dele e buscando, assim, a Compensação Positiva. Desse modo, até que estudos específicos tragam maiores evidências da convencionalização total desta estratégia, continuamos a considerá-la uma estratégia de Compensação Positiva que visa a minimizar os possíveis danos à relação causados pela expressão da Dissensão.

\section{A realização lingüística da estratégia "Concorde simbolicamente"}

Nos inquéritos analisados, esta estratégia é aplicada principalmente utilizando-se a expressão $j a$, aber..., a qual pode, inclusive, como mencionamos acima, estar se consagrando como uma fórmula para esta estratégia. Um forte argumento a esse favor é o fato de que ja nem sempre sinaliza concordância, podendo ser apenas uma marca, através da qual o falante sinaliza ao interlocutor que entendeu sua intenção comunicativa (cf. WEINRICH, 1976: 81). Porém, como no corpus parece ainda haver casos em que a tentativa de concordância parcial é genuína, continuamos a classificar as ocorrências de $j a$, aber... como casos de Compensação Positiva. É interessante notar que esta expressão ocorre sempre no início da intervenção do falante, o que vem ao encontro da noção de marcadores prefaciadores apresentada por RosA (1992: 63). Entre as ocorrências no corpus encontram-se os exemplos:

(ja) aber wir haben das ja nie behauptet (GUE37)

[...] ja aber wir wolln nicht von Ungeziefern reden. Herr Thoma meint mit dem Thema etwas ganz anders damit. (ALM7)

(ja) das liegt aber doch nicht im Charakter er ist unselbständig oder selbständig. das ist doch durch die Erziehung geprägt schon von ganz klein auf (MAE10)

Quando o interlocutor formula sua contribuição de forma negativa, o falante simula a concordância utilizando a partícula nein:

(nein) aber man darf es auch nicht zu weit treiben. wir leben ja nicht mehr unter Adolf Hitler, daß nun alles aus Berlin geschieht (TRA37) 
Freqüentemente, são interpostos outros elementos ou mesmo outras estratégias entre a partícula $j a$ e a conjunção aber, o que é mais um argumento contra o caráter totalmente convencional da forma $j a$, aber..., como ilustram os exemplos a seguir:

(ja) entschuldigen sie aber erst muß ich sie mal ein kleines bißchen berichtigen. [… (RDA2)

(ja) wir haben jetzt nur das: negative Bild mitgezeigt, daß da dem gegenüber auch sehr positive Beispiele gestellt werden können, ist ganz klar, aber leider $+g+i s t$ auch ein derartiger Saal eben keine absolute Ausnahme. (MEN3)

$+g+$ (ja) wenn es nun um Zahlungen gehen $+g+$ geht $+g+$ ist das ist das natürlich möglich. aber von einem bestimmten Punkt an geht es eben schlecht... (ULB18)

Além da expressão ja, aber..., há ainda vários outros casos nos, quais a concordância parcial é expressa por outros elementos que não a partícula $j a$; estes podem ser outros itens lexicais isolados, expressões com hedges ou, ainda, formulações que retomam partes da contribuição do interlocutor que o falante considera válidas. A sinalização da Dissensão propriamente dita ocorre principalmente através de aber, embora não somente, como em:

Frau Dr. Runge in manchen Punkten kann ich ihnen Recht geben in vielen allerdings nicht. zunächst einmal haben sie einen Punkt völlig vernachlässigt... (ABO1)

No corpus da pesquisa, encontramos ainda três ocorrências do uso do advérbio auch ('também') para a realização da estratégia concorde simbolicamente: através dele, o falante não inutiliza completamente a contribuição do interlocutor, mas sugere uma alternativa ou uma nova faceta do conteúdo abordado, sinalizando que ele, falante, prioriza este novo enfoque e assim, discorda daquele do interlocutor. As ocorrências do corpus são:

darf ich mal den den den Gegensatz rauskehren? Es gibt ja auch einen Nebenbuhler (ALM11)

[Leben in Wohngemeinschaft gar nicht wie in Illustrierten] aber das wird es auch geben. denn es gibt ja durchaus Kommunen verschiedener Art. (MAE17) 
ich gebe zu, daß wir natürlich ein Vielzahl von Problemen [...] noch gar nicht abgeschnitten haben. dazu zählt zum Beispiel auch, daß die Bundesregierung für die Jahre 1971 bis 1985 ein umfangreiches Straßenbauprogramm vorhat [...] ich bitte sie auch diese Überlegungen mit einzubeziehen. das sind natürlich auch alles Merkmale, die man mit erwähnen muß, die dazu beführen können, daß die Unfälle auf der Autobahn mit vermindert werden. (TRA29)

O advérbio trotzdem também causa o efeito de concordância simbólica, pois admite como válida a contribuição do interlocutor, caracterizando-a, no entanto, como sem influência sobre o conteúdo em discussão, como se pode notar nos dois únicos exemplos do corpus:

das ist ja trotzdem möglich die Freiheit der Entfaltung der Persönlichkeit. wir haben ja andere Mittel um die Persönlichkeit frei entfalten zu können... (ABO12)

(ja) sie haben aber noch immer $+g+$ trotzdem immer noch das Gefühl (ja) wenn ich mich mal verhaue, dann sind aber die Eltern wieder da [...] (MAE5)

\subsection{Relativize a opinião do interlocutor}

Ao invés de concordar simbolicamente, o falante pode procurar diminuir a discrepância entre a opinião do interlocutor e a sua própria, relativizando os pontos de conflito na contribuição do interlocutor. Desse modo, transmite a impressão de que, no fundo, ambos concordam, sendo que a Dissensão é restrita a uma interpretação divergente com respeito a determinados pontos passíveis de gradação. Um procedimento similar é apontado por SPRANZ-FOGASY sob a denominação Restrição e Expansão, conforme resenhado anteriormente no item 1.1.1.3.

Um caso especial representa uma intersecção entre as duas subestratégias de evite discordância, a relativização da opinião do interlocutor e a concordância simbólica: neste caso, o falante aceita parcialmente a opinião do interlocutor, porém já se utilizando de artifícios lingüísticos para relativizá-la e em seguida discorda claramente da mesma, como no exemplo:

(ja) das dürfte die Strafe für die Eltern sein. aber die Strafe für die Töchter ist eben dann [...] daß sie eben selbst zurechtkommen müssen... (MAE2) 


\section{A realização lingüística da estratégia "Relativize a opinião do interlocutor"}

A maioria dos exemplos da estratégia relativize a opinião do interlocutor presentes no corpus utiliza-se da partícula so aliada a um elemento semanticamente negativo, geralmente nicht, para relativizar elementos da fala do interlocutor que sejam passíveis de uma gradação, geralmente expressos por adjetivos, como mostram os exemplos a seguir:

ich kann erstens (jetzt) keine authentische Erklärung geben dafür, warum die $D G G$ eine so konservative (wie sie sagen) Einstellung einnimmt [...] aber (zweitens) möchte ich sagen, daß diese Einstellungsnahme der Frauenärzte Deutschlands [...] diese Einstellung gar nicht so konservativ ist [...] (ABO3)

(ja) ich mein sie haben vorhin gesagt, daß Ehe und Familie wahrscheinlich schädlich sind. ich glaub, das kann man nicht so einfach sagen [...] (MAE24)

O mesmo efeito pode, porém, ser também conseguido através de outras formulações:

[...] $+g+(j a)+g+i c h$ glaube, $d a \beta+g+$ die freundlichen Worte, die Breschnjew für Honecker gefunden hat, $+g+$ noch nicht sehr viel besagt. (ULB2)

[...] erstens die junge dame sagte sie möchte nicht heiraten, sie möchte selbständig sein. ich weiß nicht, inwieweit man das als selbständig bezeichnen kann:, das hat mich erst mal so $+g+$ skeptisch berührt (MAE37)

O falante pode, também, minimizar o grau de contingência de uma proposição do falante, apresentando-a como menos provável, como no seguinte exemplo, no qual são usados os substantivos Möglichkeit (possibilidade) e Wahrscheinlichkeit (probabilidade), para caracterizar a afirmação do interlocutor, de que haveria razões políticas para $o$ afastamento de Ulbricht:

wenn politische Gründe sein sollten, was wir wirklich nicht wissen, was wir als eine Möglichkeit $+g+$ aber nicht vielleicht nicht einmal als eine Wahrscheinlichkeit nennen können, dann glaube ich nicht, daß sie dort liegen $+g+$ wie ich aus ihren Worten entnahm, ich glaube nich, daß man Ulbricht in den Hintergrund drängen wollte mit diesem Fernbleiben... (ULB1)

Outra possibilidade de relativizar a opinião do interlocutor é apresentar a sua versão como sendo apenas uma dentre várias possíveis, como em: 
mir ist das alles mir ist die Definition zu abrupt und mir ist auch die Interpretation von Herrn Honig zu abrupt. [...] ich glaube es gibt viele Möglichkeiten von Bouletten... (ALM9)

und die Einfahrtsmarkierung [...] die Ansichten darüber sind also technisch sehr laufen technisch sehr auseinander [...] (TRA27)

A partícula nur, juntamente com elementos semanticamente negativos, também é utilizada para implicar que há outras possibilidades além daquela apresentada pelo interlocutor:

mir ist das alles mir ist die Definition zu abrupt und mir ist auch die Interpretation von Herrn Honig zu abrupt. [...] Boulette ist nicht nur eine Fleischspeise. Boulette ist nicht nur dieses [...] (ALM9)

[...] a:ber im Sinne einer Änderung der Indikationen dann finde ich das nicht nur: konservativ. sie haben zwar sehr konservativ gesagt... (ABO3)

O falante pode ainda alegar que a versão do interlocutor abrange apenas alguns aspectos da questão, sendo, assim, incompleta, como nas ocorrências:

$+g+$ (ja) wenn es nun um Zahlungen gehen + g+ geht $+g+$ ist das ist das natürlich möglich. aber von einem bestimmten Punkt an geht es eben schlecht... (ULB18)

(ja) (also) die Geschwindigkeitsbegrenzungen in Frankreich sind ja zunächst versuchsweise für ein halbes Jahr eingeführt worden auf ganz bestimmten Straßen [...] (TRA24)

O advérbio kaum também foi utilizado para relativizar a opinião do interlocutor. Como já mencionamos no item 3.2.2.1, kaum é apontado como o elemento mais próximo ao pólo negativo, em um contínuo entre ja e nein. No corpus da pesquisa, temos apenas a seguinte ocorrência do uso de kaum:

[...] ich weiß nicht, ob das immer etwas Gutes ist (nich?) ich will man kann es doch wohl kaum als gut bezeichnen, wenn im ganz bestimmten Ländern eben noch sehr rückschrittliche Tendenzen herrschen. (ALE6)

Uma outra possibilidade de relativização da opinião do interlocutor, que ocorreu principalmente ligada à estratégia concorde simbolicamente, apresenta como expediente lingüístico o uso dos verbos modais dürfen, können e mögen, três dos assim chamados verbos modais. 
O Dicionário de Língüística define os "modais" ou "auxiliares modais" como "a classe dos auxiliares do verbo que exprimem as modalidades lógicas (contingente vs. necessário, provável vs. possível)" (DuboIs, 1995: 413), citando em português os verbos poder e dever. Em alemão, há um grupo composto tradicionalmente por seis verbos - dürfen, können, mögen, müssen, sollen e wollen - que desempenham essa função e são denominados Modalverben. Diversos estudos foram realizados sobre a sintaxe e a semântica dos Modalverben em alemão, inclusive contestando seu caráter de verbos auxiliares (cf. ÖHLSCHLÄGER, 1989). Com isto em vista, optamos por utilizar o termo mais genérico "verbos modais" ao invés de "auxiliares modais".

Utilizando-se de verbos modais, o falante pode gerenciar o grau de contingência atribuído pelo falante a um enunciado, deixando ao interlocutor uma possibilidade de, ao menos formalmente, interpretar a Dissensão como não totalmente inevitável, mas apenas possível. Segundo ÖHLSCHLÄGER (1989), os verbos modais no alemão, em seu significado epistêmico, organizar-se-iam da seguinte maneira em uma escala, da quase certeza para uma simples possibilidade ${ }^{22}$ :

\begin{tabular}{|c|c|c|c|}
\hline $\begin{array}{l}\text { e muß IP } \\
\text { e dürfte IP } \\
\text { e mag IP }\end{array}$ & o falante & $\begin{array}{l}\text { está (bastante) certo de } \\
\text { considera provável } \\
\text { considera bem possível }\end{array}$ & $\begin{array}{l}\text { que o conteúdo } \\
\text { representado por IP } \\
\text { exista/ocorra }\end{array}$ \\
\hline
\end{tabular}

(cf. ÖHLSCHLÄGER, 1989: 207)

Com base nesta escala, o falante pode utilizar-se de um verbo modal apropriado para minimizar o grau de probabilidade que ele atribui à contribuição do interlocutor, preparando o terreno, por assim dizer, para uma Dissensão mais incisiva, realizada posteriormente, como mostram os exemplos:

\footnotetext{
${ }^{22}$ Eine mit einem Satz der Form e muß/dürfte/mag/kann IP ausgedrückte Proposition ist dann und genau dann wahr, wenn der Sprecher (ziemlich) sicher ist/es für wahrscheinlich/sehr gur möglich/möglich hält, daß der mit der IP bezeichnete Sachverhalt besteht (ÖHLSCHLÄGER, 1989: 207)
} 
und hier möchte ich auch darauf kommen, die Aktualität, die jetzt der Abtreibung gezollt wird, ist gar nicht so groß [...] vielleicht mag es darauf zurückzuführen sein, daß die sogennante Dunkelziffer größer geworden ist, aber sicher auch darauf, daß die Abtreibung nicht mehr das: Problem ist, wie es früher war... (ABO13)

das ist das ist eine Frage des Alters, wie alt das Kind ist, wenn das Kind $+g+5$, 6, 3 oder 4 Jahre alt ist $+g+$ (kann sein) braucht er die Mutter, wenn das Kind 14 ist $15+g+$ ist es vielleicht ganz froh, daß die Mutter mal nicht da ist... (MAE27)

No corpus da pesquisa, encontramos uma ocorrência do uso do verbo können nesta estratégia, quatro do verbo mögen e uma ocorrência de dürfte. É interessante notar que a forma mais utilizada, mögen, é a segunda forma mais próxima do pólo de menor probabilidade na escala, o que poderia ser o resultado de um raciocínio pelo qual a opinião do falante é fortemente relativizada, mas que evita os pólos da escala, para, por um lado, não perder a força da Dissensão e, por outro, para não formular a concordância de modo demasiado fraco.

\subsection{Busque concordância: relativize a própria opinião}

Nesta estratégia, o falante procura, na contribuição do interlocutor, pontos com os quais a concordância é possível, mesmo que parcialmente, retomando-os, evidenciando-os e procurando, desse modo, mostrar seu interesse e apreço pelas idéias do mesmo. Há uma certa semelhança entre a estratégia busque concordância e a evite discordância, apresentada no item 3.2.2.4.1. A diferença está no peso dado a cada um dos "lados" da Discordância. Ao evitar a discordância, o foco do falante recai sobre a Dissensão em si, sendo que a concordância parcial é apresentada com pouca ênfase, apenas para expressar respeito à Face do interlocutor. Ao buscar a concordância, o falante relativiza sua própria opinião e enfatiza os pontos em comum com a opinião do interlocutor, diminuindo a importância da Dissensão propriamente dita.

aber der Präsident des Hauses muß bei der Interpretation des Willens der Mitglieder dieses Hauses sich zurückhalten. sie können als Abgeordneter der CDU ihre persönliche Interpretation nach ihrem Urteil und ihrem Willen aussprechen. (COA34) 
Aqui, o falante expressa sua discordância quanto ao fato de o interlocutor, na qualidade de líder do parlamento, ter apresentado sua opinião quanto às intenções dos parlamentares. Porém, relativiza sua própria opinião ao acrescentar que o interlocutor, quando estiver falando como um deputado, pode apresentar sua opinião pessoal.

\section{A realização lingüística da estratégia "Busque concordância"}

Analisando-se os inquéritos da pesquisa, constatamos que esta estratégia se realiza principalmente através de formulações que destaquem positivamente aspectos levantados pelo falante, como em:

also darf ich ihnen sagen, daß ich mit ihnen in dem Punkt voll übereinstimme [...] insofern haben sie mein Ja. nur: stimme ich mit ihnen nicht überein in ihrer These, daß... (ABO2)

ou neste outro exemplo, no qual a falante reconhece como válida a afirmação do interlocutor, de que poucos médicos são punidos por praticarem abortos:

(nein) [...] solange dieser Paragraph besteht [...] und solange, wie eben die Ärzte sich abgeschreckt fühlen ist auch dieser Paragraph für Deutschland noch sehr gültig, auch wenn nur wenige bestrafft werden (ABO26)

O falante pode também relativizar seus argumentos contrários à contribuição do interlocutor aproximando, assim, novamente, seus pontos de vista após a expressão da Dissensão. Neste exemplo, o falante discorda do interlocutor, que havia sugerido uma conferência de responsáveis pela segurança no trânsito, dizendo que tal conferência já existia, mas em seguida relativiza sua opinião, dizendo que "aparentemente não havia servido para nada até o momento":

$+g+$ es gibt diese es gibt diese Konferenz ja schon [...] aber ganz offensichtlich hat das bisher nichts genützt... (TRA19)

Nesta outra ocorrência, o falante relativiza sua Dissensão sobre a afirmação do interlocutor, de que o número de acidentes de trânsito havia caído nos Estados Unidos: 
aber die USA sind kein Traumland der $+g+$ gegen Verkehrsunfallziffern. $+g+$ umgerechnet $+g+$ Indexziffern sind $+g+$ sogar höher als bei uns aus Gründen, die aber nun wieder mit $+g+$ großen Fahrstrecken und so weiter zusammenhängen. (TRA70)

e, neste outro exemplo, após uma longa explicação de que não restringia a sua escolha profissional em razão de um pensamento tradicional, a falante acaba admitindo essa possibilidade:

(nein) ich halt... ich schränke mich deshalb schon im vorhinein ein $+g+$ in der in der Auswahl meines Berufes. z.B. Lehrerin das heißt Halbtagsstellung (ja) es ist nicht sicher, daß ich heirate, es ist nicht sicher, daß ich mal mich nicht scheiden lassen [...] deswegen ist es auf jeden Fall wichtig, daß ich einen Beruf habe, um selbständig zu sein. aber ich lebe doch vielleicht noch so in der Tradition, daß ich vielleicht doch: ganz gerne heirate und darum kalkuliere ich auch mit ein. (MAE40)

Como se pode observar a partir dos exemplos, as formulações desta estratégia dependem do contexto próximo, não havendo elementos lingüísticos que a caracterizem, excetuando-se os casos de uso de auch para sinalizar que ambos compartilham ao menos alguns pontos da opinião sobre o conteúdo em questão, como em:

$+g+($ Frau ...) ich wollte sie nur darauf aufmerksam machen, $+g+d a \beta+g+$ eine (ja) [...] Mark mehr für Autofahrer oder daß sie schlechthin den Autofahrer nicht mit dem Hund vergleichen können. ich bitte sie wirklich das zu sehen. $+g+$ ich habe auch Verständnis dafür, daß sie irgendwo Sorgen mit Hunden haben [...] seien sie so freundlich und halten sie das (bitte) auseinander das ist nicht vergleichbar. (TRA53)

aber finden sie denn, daß man nicht theoretisch auch einen sich einen Kon:trapunkt vorstellen könnte? dasselbe Stück aber nicht $+g+d a \beta$ der Moderator absolut Sprachrohr der Redaktion sein muß, ich stell es nur zur Diskussion. ich bin auch an sich nicht der Meinung (MOD3)

\subsection{Crie/pressuponha pontos comuns}

Esta estratégia é um desenvolvimento da estratégia anterior. Quando não encontra nenhum ponto em comum com a contribuição do interlocutor que possa ser evidenciado com a estratégia apresentada no item anterior, o falante tem a possibilidade de criá-los através de artifícios que manipulam as pressuposições, fazendo com que se tenha a impressão de que ele e o interlocutor dividem as mesmas convicções e conhecimentos, seguem a 
mesma linha de raciocínio ou chegaram a uma mesma conclusão. Frequentemente, tal efeito é obtido gerenciando-se a distância entre os pontos de vista do falante e do interlocutor, através da escolha de formas verbais e adverbiais adequadas, como, por exemplo, na escolha do verbo kommen ao responder um chamado em ich komme schon, através do qual o falante dá a impressão de estar junto ao interlocutor. Outra possibilidade é o uso de perguntas negativas, as quais geralmente pressupõem uma resposta afirmativa, como no caso de "você não acha isto lindo?" ou no seguinte exemplo do corpus:

[...] kann er es wirklich ausdrücken? braucht nicht der Filmbericht dazu eben noch (ich möcht jetzt nicht sagen den Ausgleich des Moderators) aber die Ergänzung oder die Vertiefung? (MOD4)

Outro artifício muito importante é a apresentação, por parte do falante, de conteúdos como se fossem pressuposições comuns a ele e ao interlocutor, mesmo que esse nem sempre seja o caso, constituindo, assim, uma base comum sobre a qual, ao menos pro forma, não há discordância entre eles, como forma de compensar a Dissensão

\section{A realização lingüística da estratégia "Crie/pressuponha pontos em comum"}

Além do uso de perguntas negativas, como exposto acima, às vezes o falante apresenta alguma informação como se ela fosse conhecida tanto por ele como pelo interlocutor, através do uso de artigos definidos ou, ainda, de expressões do tipo como todos sabem... .

nun hat man ja aber (und das wissen wir alle [...]) so etwas wie Richtgeschwindigkeit eingeführt.[...] (TRA3)

Em algumas línguas, entre elas o alemão, isso pode também ser conseguido através do uso de determinadas partículas modais.

A análise do corpus apresentou os seguintes elementos lingüísticos como os mais utilizados para a realização desta estratégia: 


\section{i) Partículas modais}

Determinadas partículas modais parecem ser especialmente adequadas para a realização da estratégia crie/pressuponha pontos em comum. Nesta estratégia, o falante formata sua contribuição de modo que aquilo que ele apresenta seja entendido como mutuamente pressuposto ou aceito. Para esta finalidade, as partículas modais mais utilizadas foram $j a$, eben, also, natürlich, nun einmal. Entre estas, é grande o predomínio de ja, com 34 ocorrências, seguida de eben, com 22 exemplos no corpus.

- $\quad J A$

O Lexikon deutscher Partikeln apresenta nove variantes de significado para a partícula $j a$, sendo que todas têm um traço em comum, a fixação (Festlegung) do falante em uma atitude assertiva (o conteúdo é aceito como correto ou adequado), pressupondo, ainda, que o interlocutor partilha do conhecimento do falante sobre o tema (cf. HELBIG, 1990: 172). Na mesma obra, o primeiro sentido atribuído a ja, como partícula modal, é o seguinte:

Sinaliza o conteúdo expresso como conhecido tanto pelo falante quanto pelo interlocutor (= como nós dois sabemos), ou ainda como muito evidente ou válido em qualquer situação (allgemeingültig); refere-se a um conhecimento prévio comum a ambos, pressupõe consenso (uma base comum para a comunicação) e/ou apela à concordância. $\mathrm{O}$ falante pressupõe o conteúdo como conhecido, mas gostaria de certificar-se de que o interlocutor o tem presente (como que recuperando-o na memória) (cf. HelBiG, 1990: 165) ${ }^{23}$

LÜTTEN, em estudo que analisa as partículas $j a$, doch e eben como elementos que podem assumir a função de recorrer a uma base comum entre falante e interlocutor, explica do seguinte modo os efeitos do uso de ja em afirmações:

Quando um falante enuncia (D) [exemplo D: Du bist ja in der Stadt gewesen], confronta $S_{2}$ [interlocutor] com um fato ou uma opinião como claro e certo, ele afirma algo, que parece ter validade sem sombra de dúvida. Aqui $S_{2}$ terá provavelmente muito pouca chance de questionar algo, já que a certeza de um

\footnotetext{
${ }^{23}$ Signalisiert den geäußerten Sachverhalt als dem Sprecher und dem Hörer bekannt (=wie die beide wissen) oder gar als evident bzw. allgemeingültig, bezieht sich auf gemeinsames Vorwissen, setzt Konsens (eine gemeinsame Kommunikationsbasis) voraus und/oder appeliert an Übereinstimmung. Sprecher setzt den Sachverhalt als bekannt voraus, möchte sich jedoch vergewissern, ob er gegenwärtig ist (ruft ihn gleichsam ins Gedächtnis zurück). (HeLBIG, 1990: 165)
} 
evento ou a certeza da validade, da 'verdade' de uma opinião é garantida pelo enunciado de $\mathrm{S}_{1}$. Através do uso de $j a$ apela-se claramente à base comum de argumentação ou de ação. (LÜTTEN, 1979: 35) ${ }^{24}$

Nesse sentido, ja é um elemento lingüístico especialmente adequado para manipular pressuposições, apresentando-as como se fossem consenso entre os participantes da interação, como nos exemplos:

ich glaube, daß man zwar immer einige Einfälle haben muß, um einen guten Deutschunterricht zu machen denn der Deutschunterricht hängt weitgehend ja auch vom Lehrer ab. (ALE2)

das тиß ja nicht die gleiche Kindergärtnerin sein (MAE23)

darf ich mal den den den Gegensatz rauskehren? Es gibt ja auch einen Nebebuhler (ALM11)

[daß es sich um Leben handelt dürfte unbestritten sein] Das wird ja nicht bestritten das wird nicht bestritten. (ABO9)

[...] es tut mir leid, daß ich hier abbrechen muß,[...] aber ich werde ja ständig von den Herren der Kamera gedrängt... (POL25)

(ja) aber damit hört s ja net auf... (TRA15)

HELBIG diferencia a partícula modal ja da partícula de resposta homônima (Antwortpartikel). Entre os usos da partícula de resposta ja, aponta um que apresenta duas ocorrências no corpus:

[...Ärzte fühlen sich in dieser Beziehung ihrem hypokratischen Eid verpflichtet] da muß ich sie unterbrechen (Kollegin). Hypokrates hat davon nichts gesagt (ja?). also man darf den Arztberuf nicht überideologisieren [...] (ABO29)

und das andere $+g^{+}$das junge Fräulein erst vierzehn hat noch keine Vorstellungen. $+g+i$ ich glaube heutzutage ist die Jugend im Alter von 14 schon so weit (ja?), daß sie überhaupt eine Vorstellung hat. (MAE38)

Neste uso da partícula, o autor afirma que a mesma serve, por um lado, para certificar-se da atenção do interlocutor e, por outro, para reforçar a certeza de uma afirmação do falante, equivalendo à pergunta negativa

\footnotetext{
${ }^{24}$ Äußert ein Sprecher (D), so stellt er eine Tatsache oder Meinung $S_{2}$ gegenüber als gewiß und sicher hin, er assertiert etwas, was fraglos Gültigkeit zu haben scheint. Hier wird $S_{2}$ wohl am wenigsten Anlaß haben, etwas in Frage zu stellen, da die Gewißheit eines Ereignisses oder die Gewißheit der Gültigkeit, 'Wahrheit' einer Meinung durch die Äußerung von $S_{1}$ garantiert ist. Durch die Verwendung von ja wird also am deutlichsten auf die gemeinsame Argumentations- und Handlungsbasis rekurriert. (LÜTTEN, 1979: 35)
} 
nicht wahr? ('não é verdade?') (cf. Helbig, 1990:172). Desse modo, também a partícula de resposta ja, utilizada como tag-question, é um recurso lingüístico para a realização da estratégia de simular pontos comuns entre falante e interlocutor.

\section{- $\quad$ EBEN}

Do mesmo modo que ja, eben também é bastante utilizada para manipular as pressuposições, criando pontos em comum com o interlocutor e, mais do que isso, bloqueando futuros debates, o que a torna muito apropriada em expressões de Dissensão. Segundo HelBIG, o uso de eben:

faz com que uma afirmação seja categórica, apresenta-a como evidente e válida em qualquer circunstância, imunizando-a contra outras justificativas, sugerindo a necessidade imanente do conteúdo e, principalmente, a impossibilidade de mudanças, insinuando que o falante não pode modificar o conteúdo em questão. A facticidade do conteúdo é apresentada como uma justificativa não passível de discussão, perguntas sobre razões adicionais são bloqueadas. Deve-se fechar questão sobre o assunto; por isso, atua freqüentemente como bloqueador da conversação (cf. HELBIG, 1990: 120) ${ }^{25}$

Também LÜTTEN afirma que o falante, através do uso de eben, exorta o interlocutor a reconhecer o conteúdo em questão como necessário e inevitável (cf. 1979: 35), constituindo, dessa maneira, um ponto de consenso entre ambos, sobre o qual vai-se negociar a Dissensão.

No corpus da pesquisa, encontram-se, dentre outros, os seguintes exemplos do uso de eben na estratégia crie/pressuponha pontos comuns:

$+g+$ (ja) wenn es nun um Zahlungen gehen $+g+$ geht $+g+$ ist das ist das natürlich möglich. aber von einem bestimmten Punkt an geht es eben schlecht... (ULB18)

(ja) da gibt es eben verschiedene Meinungen (nicht wahr?) (SEX2)

[...]und $+g+i c h$ meine ich möcht jetzt nicht auf $+g+$ Verschiedenes noch zurückgehen aber es wird eben hier $+g+$ einzelne Delikte werden herausgegriffen. es wird so getan, als seien das Einzelfälle. ich würde sagen es ist die Spitze eines Eisberges [...] (MEN18)

\footnotetext{
${ }^{25}$ Macht eine Aussage kategorisch, stellt sie als evident und allgemeingültig hin, immunisiert sie weitgehend gegen andere Begründungen und suggeriert die innere Notwendigkeit des Sachverhalts und vor allem seine Unabänderlichkeit, deutet an, daß der Sprecher den Sachverhalt nicht verändern kann. Die Faktizität des Sachverhalts wird als nicht weiter diskutierbare Begründung ausgegeben, Fragen nach zusätzlichen Gründen werden blokiert. Es soll Schlußstrich gezogen werden, deshalb oft redeabbrechend. (HelBIG, 1990:120)
} 
No caso de nun einmal, a partícula einmal é definida como "factitivaconstativa, apresentando um conteúdo como evidente e imutável e atuando preventivamente contra futuras justificativas", equivalendo, assim, a eben $\mathrm{e}$ sendo freqüentemente associada a nun (cf. HELBIG, 1990: 135). O conteúdo é apresentado como pressuposto e aceito por todos os participantes da interação, como na única ocorrência do corpus:

(ja) und das, was Herr Riha sagte, (vielleicht ein Kommentar) und ich finde das ist gut: so in der BRD. Lern:zielentscheidungen sind: nun einmal politische Entscheidungen [...] aber diese Konkurrenzsituation hat ja etwas Gutes. (ALE5)

\section{ii) Perguntas negativas}

Do mesmo modo que o apresentado para as partículas modais, o falante pode também pressupor pontos comuns entre os participantes da interação através do uso de perguntas negativas. Como estas geralmente pressupõem uma resposta afirmativa, dão a entender que o falante tem conhecimento das opiniões e atitudes do interlocutor e apresentam, desse modo, a posição do falante como se ela fosse partilhada pelo interlocutor. Nesta estratégia, encontramos também o uso de tag-questions, que apelam ao falante, pressupondo concordância. Dentre as ocorrências no corpus, encontram-se os seguintes exemplos:

wollen wir da jetzt nicht einen Strich drunter machen? (COA27)

(ja) da gibt es eben verschiedene Meinungen (nicht wahr?) (SEX2)

[Wenn der Film bzw. der Bericht schon gut ist, braucht man keinen Moderator] aber ich glaube, [...] man müßte einmal zuerst die Frage stellen kann der Film der politische Filmbericht [...] heute das Abstrakte [...] wirklich ausdrücken? braucht nicht der Filmbericht dazu eben noch (ich möcht jetzt nicht sagen den Ausgleich des Moderators) aber die Ergänzung oder die Vertiefung? (MOD4)

[...] (ich mein) ich gebe zu, das ist eine große Ähnlichkeit. aber bringen sie da nicht einiges durcheinander? versteinerte Bouletten? ich mein $+g+i c h$ (ALM16)

[Kinder, die das Haus verlassen, fühlen sich bestraft] (nun) man $+g+$ man man kann nicht als Tochter aus dem Haus gehen und sagen denen zeige ich s jetzt (ne?) sondern man muß $+g+$ man läßt hinter sich ein bißchen ein Trümmerfeld zurück. man bricht: mit zu Hause. (MAE1) 
Um outro exemplo de tag-question destinada a manipular o interlocutor em direção a uma resposta afirmativa é oder?, que pode ser entendida como uma forma elíptica da pergunta negativa oder (etwa) nicht? ("ou não?'). No corpus da pesquisa, encontra-se apenas uma ocorrência:

aber Anhaltspunkte finden sie bei Menschen, die sie umgeben, mit denen sie leben, oder? (MAE31)

\section{iii) Outras possibilidades de realização}

O falante pode ainda, através de determinadas expressões, pressupor que o interlocutor partilhe de seus conhecimentos e opiniões, simulando, assim, pontos comuns, como nos exemplos a seguir:

wir haben sie (Augenblick) wir haben sie nicht zur Koalisionsfrage gemacht, wie sie wissen... (COA33)

ich wollte grade das Gegenteil sagen. wir sind alle der Meinung das ist notwendig wir brauchen mehr Ärzte [...] (MEN14)

Em uma outra possibilidade da criação de pontos comuns, o falante atribui ao interlocutor opiniões, sentimentos e atitudes, quando elas, de fato, são suas, como na única ocorrência constante do corpus:

(ja) sie haben aber noch immer + g+ trotzdem immer noch das Gefühl (ja) wenn ich mich mal verhaue, dann sind aber die Eltern wieder da [...] (MAE5)

\subsection{Intensifique o interesse: aproxime o interlocutor}

Através desta estratégia, o falante apresenta sua contribuição à interação de modo a dar ao interlocutor a idéia de que este participa das experiências ou sentimentos do falante, sendo, portanto, iguais $\mathrm{e}$ merecedores de respeito mútuo. BROWN \& LEVINSON destacam como possibilidades de realização desta estratégia o uso do presente histórico, de discurso direto, perguntas fáticas e expressões que procuram envolver afetivamente o interlocutor, de modo a fazer da contribuição do falante uma "boa história", da qual o interlocutor se sinta parte integrante. Dessa maneira, possíveis FTAs, como a Dissensão, seriam minimizados porque o 
falante não estaria realmente "contra" o interlocutor, mas sim, ambos partilhariam os mesmos atos e sentimentos.

\section{A realização lingüística da estratégia "Intensifique o interesse: aproxime o interlocutor"}

Entre os recursos citados, encontram-se no corpus principalmente ocorrências do uso do discurso direto. No primeiro exemplo a seguir, a falante apresenta seus pensamentos e sentimentos direta e intensamente, de modo a permitir aos demais que estes participem de tais emoções; no segundo exemplo, o falante verbaliza de forma direta o pensamento que atribui aos motoristas, para que todos possam compartilhá-lo:

[...] das geht bei mir nich etwa so, daß ich dann irgendwelche Freunde empfangen will oder so [...], sondern [..] daß ich sage (ach) (wie schön) ich kann mal lange Fernsehen gucken... (MAE28)

[...] und man soll damit aufhören, daß immer der Autofahrer noch etwas dazu tun muß. der zahlt: bereits genug. Und ob des jetzt eine Mark für das ist und dann kommt der andere und sagt (na) es kommt auf eine weitere Mark auch nicht an und auf die kommt s nicht an (also) ich mein irgendwo ist die Grenze (TRA13)

Há também casos do uso de expressões que convidam o interlocutor a participar do raciocínio do falante, como schauen Sie ('veja'):

aber man kann eben $+g+$ solche Dinge nicht danach ausrichten, wenn einmal ein außergewöhnlicher Zustand wie Schnee herrscht, denn (schauen sie) da müßte man sagen die ganze Fahrbahnmarkierung können wir abschaffen [...] (TRA26)

Comentando o emprego do presente histórico (uso do tempo presente para narrar eventos passados), BROWN \& LEVINSON (1978: 111) ressaltam que esse recurso "leva o interlocutor diretamente para o meio dos eventos que estão sendo discutidos, ao menos metaforicamente". Este e outros exemplos de gerenciamento da dêixis temporal são bem explicados por FIORIN (1996) em seu livro As astúcias da enunciação. Em um esquema à página 227 e melhor detalhado aqui no item 3.2.2.5.9, FIORIN demonstra como a dêixis temporal pode ser gerenciada de modo a produzir efeitos de aproximação ou afastamento em relação a um determinado evento. Neste esquema, o efeito aspectual "inacabado" é associado ao pólo de 
aproximação. Baseando-nos nestas reflexões, consideramos que a seguinte ocorrência do corpus encontra-se no espírito desta estratégia:

(Herr Littmann) (Herr Littmann) es kommt nicht auf die eine Mark an. das ist sicher. aber dann kommt wieder was und wieder was und immer zusätzlich... (TRA12)

O uso da repetição faz com que o interlocutor sinta-se "vivenciando" o problema, que parece repetir-se indefinidamente, e assim, consideramo-lo também como um modo de realizar a estratégia intensifique o interesse: aproxime $\mathrm{o}$ interlocutor.

Outro recurso que tem o efeito de aproximar o interlocutor do falante é o uso de Umgangssprache, linguagem coloquial menos esperada em situações formais, como em discussões na mídia, e que, quando utilizada, tem o efeito de tornar a conversação menos formal, mais descontraída, como nos exemplos:

nicht abwertend, aber $+g+$ die armen Dummen die stehen an der Autobahn... (TRA62)

ich kann ihnen eine relativ dumme Antwort daruf geben. das geht bei mir nich etwa so, daß ich dann irgendwelche Freunde empfangen will oder so [...], sondern [..] daß ich sage (ach) (wie schön) ich kann mal lange Fernsehen gucken... (MAE28)

jetzt sind s schon Scheiben. also ich find es wird immer flacher das Ding (ALM22)

Outra das possibilidades do falante para envolver afetivamente o interlocutor e , dessa forma, aproximar-se dele, é apresentar sua contribuição de modo especialmente vívido, por exemplo, através de exageros, inclusive prosódicos.

ich meine also, daß das auf keinen Fall ne Strafe ist. ich bin ja von zu Hause abgehauen und $+g+i$ ch habe so wahnsinnig viel gelernt in der Zeit [...] ich bin also viel selbstsicherer, als als ich zu Hause jemals war... (MAE3) 


\subsection{Graceje}

BROWN \& LEVINSON justificam a classificação de gracejos entre as estratégias de Compensação Positiva da seguinte maneira: desde que gracejos são baseados em um background de conhecimentos e valores comuns, seu uso pode servir exatamente para enfatizar a existência desse background comum aos participantes da interação e minimizar FTAs, como, por exemplo, no caso de pedidos como: "que tal você me emprestar a sua lata velha (i.e. seu carro) este fim de semana?" O uso do humor parece "desmontar" o perigo, colocando-o num contexto mais leve, que procura impedir atitudes agressivas frente ao FTA, como nos dois únicos exemplos no corpus, ditos em um contexto bem jovial:

(nein) (nein) (nein) (nein) an den Namen Strauß brauch ich mich nicht zu gewöhnen (COA9)

(es hat mehr schlecht als recht funktioniert) (COA19)

As ocorrências de uso da estratégia graceje presentes no corpus são realizadas através de formulações referentes ao contexto geral da interação e ao conhecimento token dos participantes, unidas à entonação e a gestos. Desse modo, não há possibilidade definir elementos lingüísticos específicos para sua realização.

\subsection{Use identificadores grupais}

Através do uso de expressões próprias de um determinado grupo social ou familiar (gíria, jargão, termos carinhosos etc.), o falante pode dar ao interlocutor a impressão de que ambos pertencem ao mesmo grupo, o que é a base da Compensação Positiva. Note-se que o interlocutor não precisa necessariamente considerar o falante como pertencente a esse grupo, e que o uso de tal estratégia é bastante arriscado, pois o interlocutor pode não gostar da familiaridade assumida pelo falante. 


\section{A realização lingüística da estratégia "Use identificadores grupais"}

Segundo BROWN \& E LEVINSON, o uso de linguagem específica de um grupo social ressalta o grau de proximidade entre falante e interlocutor, pois que ambos partilham de um código teoricamente fechado aos nãomembros (cf. op.cit., p.115ss.). Em nosso corpus, encontramos apenas dois exemplos do uso do termo Kollege, que salienta a filiação, tanto do falante quanto do ouvinte, a um determinado grupo profissional comum. Porém, nos dois casos encontrados no corpus, a utilização do termo parece antes ter a finalidade de ressaltar o fato de que ambos, pertencendo ao mesmo grupo profissional, estão igualmente autorizados a formular juízos conflitantes sobre temas de sua profissão:

da muß ich sie unterbrechen (Kollegin). Hypokrates hat davon nichts gesagt (ja?) (ABO29)

(nein) nicht für den Staat (Herr Kollege Mischnick) also bleiben wir hier bei einfach beim Steuer der Wahrheit [...] (COA16)

\subsection{Dê (ou peça) razões}

Esta estratégia é a mais utilizada nas ocorrências de expressão de Dissensão no corpus da pesquisa, com uma freqüência de uso de $16,14 \%$. BROWN \& LEVINSON explicam o fato de considerarem o oferecimento ou o pedido de justificativas como uma estratégia de Compensação Positiva da seguinte maneira: envolvendo e guiando o interlocutor no seu raciocínio e assumindo que o relacionamento entre ambos é baseado na reciprocidade, o falante espera que o interlocutor veja o quanto o seu procedimento é razoável e, portanto, justificável. Os autores lembram, também, que esta estratégia pode ser usada agressivamente, como no caso em que se pede por razões que se sabe que o interlocutor não pode apresentar, implicando assim uma crítica ou colocando-o em desvantagem (cf. op.cit., p.133), como no seguinte exemplo do corpus:

A: darf ich (Herr Honig). ich weiß nicht. sie sind immer gleich so rasch mit ihren Urteilen [...]

$B$ : wieso immer gleich? wir haben gerade erst angefangen. (ALM3)

Neste exemplo, o falante B sinaliza sua Dissensão para com a falante A pedindo-lhe razões que justifiquem a sua afirmação de que o falante B é 
"sempre tão apressado em seus julgamentos". O falante B, realmente, não espera receber uma resposta, pois ele próprio já fornece razões pelas quais ele acredita que a afirmação de A está errada, já que, se eles "acabaram de começar" a discussão, a falante A não tem como justificar sua afirmação. Desse modo, o falante B, através da estratégia de pedir e fornecer razões, sinaliza sua Dissensão e a fundamenta, desarmando A.

\section{A realização lingüística da estratégia "Dê (ou peça) razões"}

Muito freqüentemente, as razões são apresentadas diretamente, sem nenhuma formulação especial, depreendendo-se, pelo contexto, que são razões que levaram o falante à expressão da Dissensão. Estritamente falando, nestes casos a estratégia dê (ou peça) razões depende da criação de uma implicatura. No entanto, não os consideramos como casos de Dissensão off record porque muito dificilmente o falante poderia eximir-se da responsabilidade de, em sua contribuição, haver apresentado razões com a intenção de expressar uma Dissensão.

No entanto, algumas formulações lingüísticas explicitam essa relação causal, servindo como uma introdução para as razões propriamente ditas. No corpus, encontram-se, na maioria dos casos, exemplos do uso de denn e weil, como em:

ich glaube doch, daß es widersinnig ist, denn $+g+$ wenn die Justiz die Frauen [...] verfolgen würde, müßte man mit zwei bis fünf Millionen Abtreibungsprozessen rechnen. [...] (ABO15)

[warum lassen wir denn nicht die Gerichte darüber urteilen?] aber, weil unsere Zuschauer ein Recht darauf haben heute und hier zu erfahren, was los ist und es nicht erst auf die Gerichte zu... (GUE12)

Em vários casos, nota-se o uso da partícula also, tanto para introduzir como para resumir a argumentação apresentada pelo falante como justificativa para sua Dissensão, como em:

... und ich finde es ist gar nicht Voraussetzung, daß einem die Eltern im Rücken liegen müssen. also ich fand, daß meine Eltern mich $+g+/ z u m$ Selbstbewußtsein/ hinführen können, und da bin ich froh darüber. (MAE4) 
aber man kann eben $+g+$ solche Dinge nicht danach ausrichten, wenn einmal ein außergewöhnlicher Zustand wie Schnee herrscht, denn (schauen sie) da müßte man sagen die ganze Fahrbahnmarkierung können wir abschaffen [...] also solche außergewöhnliche Zustände kann man eben eine Dauereinrichtung nicht abstellen (TRA26)

Uma outra faceta desta estratégia é quando o falante, ao invés de fornecer as razões de sua Dissensão, expressa-a ao pedir ao interlocutor razões que justifiquem a sua contribuição (do interlocutor), implicando que discorda dela. No corpus, encontramos exemplos do uso desta estratégia, introduzidos pelos advérbios interrogativos (Interrogativadverb, DUDEN Grammatik, 1984: 355s.) wieso e warum, por exemplo, em:

wieso immer gleich? wir haben gerade erst angefangen. (ALM3)

warum nicht? (ULB9)

Há ainda outras ocorrências de uso do advérbio interrogativo warum, mas que, considerando o contexto geral, consideramos como expedientes para a realização de perguntas retóricas, uma das estratégias off record, detalhada mais adiante no item 3.2.2.6.2.

\subsection{Inclua falante e interlocutor na atividade: gerencie a dêixis pessoal}

Assim como a dêixis temporal pode ser gerenciada para criar efeitos de aproximação, o mesmo acontece com a dêixis pessoal. FIORIN (1996: 84s.), detalhando as possibilidades de embreagem actancial, ou seja, a neutralização de oposições no interior da categoria de pessoa, apresenta 20 possibilidades de uso de uma pessoa do discurso pela outra. Dessa forma, o falante pode criar uma aproximação fictícia entre ele e o seu interlocutor, minimizando a Dissensão. Outra possibilidade é a de incluir todos os participantes da interação em uma opinião que, na realidade, é a do falante.

\section{A realização lingüística da estratégia "Inclua falante e interlocutor na atividade: gerencie a dêixis pessoal"}

No corpus da pesquisa, encontramos duas formas de uso desta estratégia. $\mathrm{Na}$ primeira, o falante utiliza a primeira pessoa do plural 
(wir/nós) pela segunda pessoa do singular (du-Sie/tu-você), como nos exemplos a seguir:

ich glaube, wir müssen jetzt vorsichtig sein, daß wir mit dem Begriff Doppelmoral nicht Verwirrung einstiften $+g+$ er wird nämlich in zweierlei Bedeutungen gebraucht [...] (SEX12)

(Frau Linau) ich würde sagen (vorsichtig) wir kommen jetzt auf ein gefährliches Feld. denn der Klops ist rund und die Boulette ist flach. (ALM13)

Ich würde denselben Standpukt vertreten, nur habe ich diese Bedenken und dann gleich auch Befürchtungen, daß wir nur: das Negative bringen [...] ich glaube auch diese positiven Ansäzte sollte man einmal sagen (MEN10)

(nein) nicht für den Staat (Herr Kollege Mischnick) also bleiben wir hier bei einfach beim Steuer der Wahrheit. in kei:nem angelsächsischen in keiner angelsächsischen Demokratie, die nur das sogennante Mehrheitswahlrecht kennt, kann man sagen, daß es eine Existenzfrage gibt des Staates oder eine Gefahr für den Staat besteht. (COA16)

Nos dois primeiros exemplos, fica claro que apenas os interlocutores precisam ser cuidadosos, já que a sua contribuição é contestada pelos falantes através da apresentação de razões. No segundo caso, pelo contexto total da discussão, é patente que apenas um dos participantes apresenta somente os aspectos negativos do tema e, na terceira ocorrência, é claro que o falante considera que apenas o interlocutor está se "afastando da verdade".

$\mathrm{Na}$ segunda possibilidade de gerenciamento da dêixis pessoal, o falante utiliza a primeira pessoa do plural (wir/nós) no lugar da primeira do singular (ich/eu), ou seja, atribui a todos os participantes da interação opiniões e atitudes que, na realidade, são suas, como nos exemplos a seguir:

[...] ja aber wir wolln nicht von Ungeziefern reden. Herr Thoma meint mit dem Thema etwas ganz anderes damit. (ALM7)

[muß das eine Entscheidung des Auswärtigen-Amtes sein?] (ja) das ist das Ergebnis $+g+$ doch unserer Planungsuntersuchungen (nicht?) [...] (EXT4)

[darf ich mal ihren Dialog unterbrechen...] bloß ich meine wir sollten $+g+u m$ noch mal an das anzuknüpfen, was hier eben als Dialog umstritten war $+g+$ sollten vielleicht auch darauf hinweisen, daß... (ULB21)

Este segundo procedimento assemelha-se ao caso do item 3.2.2.4.3. crie/ pressuponha pontos comum, no qual o falante também atribui ao interlocutor suas opiniões e atitudes. No entanto, naquela estratégia o falante se 
coloca na posição do outro, falando como se estivesse apenas externando pensamentos exclusivos do interlocutor, enquanto nesta o falante implica que todos os participantes partilham da sua opinião.

\subsection{Seja otimista}

Segundo Brown \& LEVINSON, quando o falante assume que o que ele deseja é também o desejo do interlocutor, o fato de apresentar explicitamente tal presunção pode levar o interlocutor a cooperar. Assim, no exemplo a seguir, o falante assume que os demais não têm nada a opor à sua contribuição:

wenn ich da nen Vorschlag mir erlauben darf, vielleicht heben wir uns das noch 10, 15 Minuten auf... (TRA1)

\section{A realização lingüística da estratégia "Seja otimista"}

Esta estratégia, pela qual o falante apresenta-se de modo relativamente presunçoso, aparece no corpus da pesquisa principalmente sob a forma de uma expressão, a qual poderíamos considerar praticamente convencional. Através de wenn ich ... darf ('se eu puder'), o falante simultaneamente solicita e dá permissão para sua tomada de turno, como se pode perceber nas seguintes ocorrências:

wenn ich was sagen darf (Herr Appel) außerdem ist ein Unterschied von der $+g+$ zwischen der Erklärung, die der Präsident im Amt vor dem Hause abgibt, und dem, was er im Rahmen einer freien allerdings öffentlichen Diskussion sagt... (COA36)

aber (Herr Dr. Seehum) wenn ich sie da $+\mathbf{g}+$ unterbrechen darf, dann frage ich mich natürlich, wenn die Mittel vorhanden wären, warum gibt es dann nicht an den an den $+g+$ stark frequentierten Autobahnen... (TRA17)

Esta expressão, wenn ich + verbo + darf, parece estar se cristalizando em uma expressão convencional. Porém, ainda a consideramos como um exemplo da estratégia seja otimista, porque o interlocutor ainda teria, ao menos teoricamente, a possibilidade de interromper o falante e negar-lhe a permissão que lhe é pedida. 
$\mathrm{Na}$ única ocorrência desta estratégia da qual não consta o verbo dürfen, o falante expressa, através de hoffentlich, a sua esperança frente aos interlocutores, de que estes não interpretarão de maneira errônea (i.e. negativa) a sua interrupção:

jetzt $+g+$ (Herr Schmidt) $+g+$ versetzen sie sich in die Situation der Journalisten [...] es tut mir leid, daß ich hier abbrechen muß, und ich komme hoffentlich nicht in den Verdacht, daß ich jetzt ein Thema abbrechen will, aber ich werde ja ständig von den Herren der Kamera gedrängt... (COA25) 


\subsection{Quadro sinótico da realização lingüística de Estratégias de Compensação Positiva na Dissensão}

\begin{tabular}{|c|c|}
\hline $\begin{array}{c}\text { ESTRATÉGIA DE COMPENSAÇÃO } \\
\text { POSITIVA } \\
\end{array}$ & REALIZAÇÃO LINGÜÍSTICA \\
\hline Dê (ou peça) razões & $\begin{array}{l}\text { formulações individuais; } \\
\text { denn, weil, also; } \\
\text { warum? wieso? }\end{array}$ \\
\hline Evite discordância & $\begin{array}{l}\text { expressão: ja/nein, aber...; } \\
\text { formulações individuais de } \\
\text { concordância parcial + aber/ } \\
\text { allerdings/trotzdem/kaum/nur/ } \\
\text { auf der anderen Seite...; } \\
\text { auch }\end{array}$ \\
\hline $\begin{array}{l}\text { Intensifique o interesse: aproxime o } \\
\text { interlocutor }\end{array}$ & $\begin{array}{l}\text { discurso direto; } \\
\text { Umgangssprache; } \\
\text { expressão: schauen sie } \\
\text { gerenciamento da dêixis } \\
\text { temporal: efeito aspectual: } \\
\text { inacabado; exagero }\end{array}$ \\
\hline Busque concordância & $\begin{array}{l}\text { repetição e/ou avaliação } \\
\text { positiva de elementos da } \\
\text { contribuição do interlocutor; } \\
\text { auch; } \\
\text { relativização da opinião do } \\
\text { falante }\end{array}$ \\
\hline Crie/pressuponha pontos comuns & $\begin{array}{l}\text { Partículas modais: ja, eben, } \\
\text { halt, nun einmal; } \\
\text { tag-questions: nicht (wahr)? } \\
\text { ne? oder? ja? } \\
\text { perguntas negativas; } \\
\text { expressões: das ist bekannt, } \\
\text { das ist klar, ich teile die } \\
\text { Bedenken, wir sind alle der } \\
\text { Meinung, wie sie wissen } \\
\text { falante se coloca na posiçãodo } \\
\text { interlocutor }\end{array}$ \\
\hline $\begin{array}{l}\text { Inclua falante e interlocutor na } \\
\text { atividade }\end{array}$ & $\begin{array}{l}\text { gerenciamento da dêixis } \\
\text { pessoal: uso da primeira } \\
\text { pessoa do plural pela segunda } \\
\text { ou pela primeira do singular }\end{array}$ \\
\hline Use identificadores grupais & termo Kollege \\
\hline Seja otimista & $\begin{array}{l}\text { wenn ich ... darf; } \\
\text { hoffentlich }\end{array}$ \\
\hline
\end{tabular}




\subsubsection{Dissensão direta com Estratégias de Compensação Negativa}

Se as Estratégias de Compensação Positiva visam a aproximar o falante e o interlocutor e a transmitir a idéia de que ambos têm opiniões e objetivos em comum, as Estratégias de Compensação Negativa procuram respeitar a Face negativa dos participantes, ou seja, evitar ao máximo a intromissão de um participante no espaço privado dos demais, facultandolhe o direito de ter opiniões e objetivos próprios, mesmo que diferentes dos seus. As Estratégias de Compensação Negativa atendem às duas primeiras regras de polidez formuladas por Robin LAKOFF: 1) não imponha e 2) dê opções (veja item 1.2.3). BROWN \& LEVINSON (1978: 134s.) apontam para o fato de que, em nossa sociedade ocidental, que valoriza muito o indivíduo, as Estratégias de Compensação Negativa são aquelas que constituem o protótipo do sentido coloquial da palavra "polidez", baseando-se no reconhecimento e na sinalização de intrusões e imposições perpetradas pelo falante frente ao interlocutor. Desse modo, o falante sinaliza que ele respeita a privacidade do interlocutor, mas que outras razões, maiores que as necessidades das Faces, levam-no a executar FTAs potenciais, entre eles, a Dissensão.

As Estratégias de Compensação Negativa, desse modo, visam a distanciar o falante de seu interlocutor, (para evitar invadir seu espaço privado) ou do ato de ameaça à Face (a fim de dissociá-lo do mesmo e evitar represálias do interlocutor). A análise do corpus da pesquisa revelou o uso de diversas dessas estratégias: foram encontrados 379 usos de Estratégias de Compensação Negativa para compensar uma Dissensão. Novamente é bom lembrar que, para a expressão de uma mesma Dissensão, pode-se combinar mais de uma estratégia negativa ou, ainda, estratégias positivas e negativas em uma mesma ocorrência. As ocorrências de usos de Estratégias de Compensação Negativa distribuem-se da seguinte maneira pelos diversos inquéritos: 


\begin{tabular}{|l|c|}
\hline \multicolumn{1}{|c|}{ INQUÉRITO } & OCORRÊNCIAS \\
\hline ABORTO & 32 \\
\hline ALEMÃO & 18 \\
\hline ALMÔNDEGAS & 37 \\
\hline COALIZ̃̃O & 30 \\
\hline EXTERIOR & 11 \\
\hline GUERRA & 19 \\
\hline MÃES & 55 \\
\hline MENTAL & 22 \\
\hline MODERADORES & 13 \\
\hline RDA & 4 \\
\hline SEXO & 16 \\
\hline TRÂNSITO & 102 \\
\hline ULBRICHT & 20 \\
\hline TOTAL & 379 \\
\hline
\end{tabular}

A necessidade de enfatizar o reconhecimento da individualidade do interlocutor e da existência de razões prementes para a expressão da Dissensão levam o falante a procurar dissociar-se, tanto quanto possível, da imposição. Tal objetivo é perseguido, no corpus, através das estratégias detalhadas nos itens que se seguem.

\subsection{Utilize formas convencionalizadas}

BROWN \& LEVINSON consideram que o choque entre o desejo de dar opções ao interlocutor e de fazer o FTA explicitamente é resolvido utilizando-se elementos convencionalmente indiretos, ou seja, expressões que, em nível semântico ou pragmático, adquiriram convencionalmente significados contextualmente claros, independentes de seu significado literal. Assim, o falante pode realizar o FTA diretamente e, ao mesmo tempo, deixar registrado o seu desejo de tê-lo realizado indiretamente (cf. BROWN \& LEVINSON, 1978: 137).

Os estudos sobre a convencionalidade intensificaram-se principalmente a partir das tentativas de explicar os assim chamados "atos de fala indiretos". O fato de uma pergunta como "você pode me passar o sal?" não ser realmente um pedido de informação sobre a capacidade do interlocutor para erguer o saleiro e passá-lo ao falante, mas sim, constituir um pedido, intrigou por muito tempo os estudiosos da Teoria dos Atos de Fala. As teorias de GRICE sobre implicaturas conversacionais e os trabalhos de Fillmore sobre o falante ingênuo e seu 
desconhecimento das convenções de uma determinada língua ${ }^{26}$ contribuíram em muito para que a convencionalidade fosse examinada em um sentido mais amplo, incluindo o estudo de comportamentos convencionais, fórmulas situacionais e mesmo convencionalidade em nível sintático. Muitos estudos têm sido desenvolvidos sobre este tema, em diversas línguas, tendo como obra de referência obrigatória os trabalhos de COULMAS (1979 e 1981), no que se refere ao uso da convencionalidade em nível pragmático.

Uma das razões para a formação e o uso de convenções é exatamente o código de ideologia e comportamento de um grupo social, o qual implica o Trabalho da Face tanto em nível comportamental como lingüístico. Assim, certas "fórmulas" ou expressões têm apenas a função de sinalizar explicitamente ao interlocutor que o falante desejaria, na realidade, ser indireto. Dessa maneira, quanto mais esforço for dispendido para tornar indireta a contribuição do falante, maior será o efeito de preservação da Face, como nos seguintes exemplos:

a) Pode me passar o sal?

b) Poderia me passar o sal?

c) Você não poderia me passar o sal?

d) Será que você não poderia me passar o sal?

O uso de formas convencionalizadas marca a intenção do falante de demonstrar seu respeito à Face ao mesmo tempo que realiza a Dissensão de forma clara. De fato, o falante expressa sua Dissensão diretamente, mas, através da expressão convencional, sinaliza ao interlocutor que o respeita e que não quer atacar sua Face. As expressões convencionais apresentam diversos níveis de convencionalidade e opacidade, sendo que, enquanto algumas formas são tão opacas que não se pode mais reconhecer os procedimentos que as geraram (p.ex.:"ir para o beleléu" = morrer, acabarse), outras ainda são perfeitamente compreensíveis a partir da semântica de seus elementos. Exemplos semelhantes aos pedidos acima são mencionados por TAGNIN como exemplos de fórmulas situacionais sintáticas (1989: 58s.), as quais têm uma parte inicial, fixa, podendo ser completadas diferentemente, de acordo com a sitação, ao contrário das fórmulas de rotina, as quais são normalmente invariáveis e fortemente ligadas à situação, como saudações e pedidos de desculpas. (cf. TAGNIN, 1989: 63ss.). As expressões convencionalizadas foram provavelmente as

\footnotetext{
${ }^{26}$ sobre este assunto veja, por exemplo, TAGNIN 1989.
} 
primeiras manifestações lingüísticas estudadas em associação com a idéia de polidez (na Teoria dos Atos de Fala, ao se estudar os "atos de fala indiretos $^{27}$ ", sem mencionar os estudos de retórica e manuais de boas maneiras) e até hoje ainda são objeto de vários estudos, geralmente ligados a situações específicas, como pedidos e agracedecimentos (HELD, 1995), pedidos e reclamações (HOUSE/KASPER, 1981), desculpas (LAUERBACH, 1982 e LANG, 1984), apenas para citar alguns.

A convencionalidade também está presente na expressão da Dissensão, embora não de forma tão específica como nos pedidos feitos através de perguntas. Um dos exemplos do corpus da pesquisa é a expressão ich weiß nicht (= não sei) no exemplo abaixo:

[...] (Herr Honig) ich weiß nicht. sie sind immer so rasch mit ihren Urteilen [...] (ALM2)

(Senhor Honig, não sei. O senhor é sempre tão apressado em seus julgamentos...)

No exemplo, ich weiß nicht não significa realmente que a falante não sabe se o que o interlocutor disse é certo ou errado, já que, em seguida, ela qualifica os julgamentos deste último como "sempre apressados". Ich weiß nicht é, aqui, apenas uma fórmula para sinalizar a não-concordância com o interlocutor. Deve-se ter em conta que as convenções não estão primariamente em uma forma lingüística, mas sim no efeito que determinadas formas lingüísticas assumem em um dado contexto (cf. BROWN \& LEVINSON, 1978: 139).

\section{A realização lingüística da estratégia "Utilize formas convencionalizadas"}

O uso de formas convencionalizadas marca a intenção do falante de demonstrar seu respeito à Face ao mesmo tempo que realiza a Dissensão de forma clara. De fato, o falante expressa sua Dissensão diretamente, mas, através da expressão convencional, sinaliza ao interlocutor que o respeita e que não quer atacar sua Face. No corpus da pesquisa encontram-se, como já mencionado, exemplos da fórmula ich/man weiß nicht.

$+g+i$ ch sage man weiß es nicht. aber ich glaube doch, daß die Umwelt immer auf einen jungen Menschen abfärbt. (MAE32)

\footnotetext{
${ }^{27}$ Sobre atos de fala indiretos, veja, por exemplo, SEARLE (1975), DAVIDSON (1975), BLUM-KULKA (1987).
} 
darf ich (Herr Honig) ich weiß nicht. sie sind immer gleich so rasch mit ihren Urteilen [...] (ALM2)

RoSA (1992: 51s.) considera a expressão "não sei", correspondente a ich weiß nicht, como um marcador de atenuação, que assinala a incerteza do locutor. Embora esse possa ser o caso em determinados contextos, as ocorrências de nosso corpus não parecem indicar incerteza, pois que o falante mantém a sua opinião discordante, mesmo após a apresentação da expressão, a qual nos parece, nestas situações, adquirir um caráter formulaico de uma não concordância expressa de forma atenuada, ou seja, é um exemplo de uma Dissensão convencionalmente indireta.

Outras formas convencionalizadas são também encontradas no corpus, como:

(nur) $\boldsymbol{o b}$ es ein Heilmittel ist, und schon und $\boldsymbol{o b}$ man es überhaupt in Verbindung $m i t+g+$ Festtagsunfallziffern $+g+$ so vordergründig in die Diskussion bringen darf, das ist die Frage. (TRA4)

[ich würde nicht heiraten] sie auch nicht? $+g+$ das ist leicht gesagt. wir werden vielleicht in zwanzig Jahren noch einmal ein Podium machen... (MAE14)

[Diskussionsleiterin als Ausnahme] wieso? will ich gar nicht sagen ich bin schließlich auch eine Tochter. und ich bin ich bin vielleicht auch schwierig an und ab. (MAE20)

[...] ich habe auch verständnis dafür, daß sie irgendwo Sorgen mit Hunden haben [...] seien sie so freundlich und halten sie das (bitte) auseinander das ist nicht vergleichbar. (TRA53)

ich muß: ̈̈berhaupt nicht. wollen sie das mal zur Kenntnis nehmen. (GUE58)

Além desses exemplos, a grande maioria dos casos compreende as fórmulas situacionais sintáticas ich darf + infinitivo ('eu posso/tenho a permissão') e ich möchte + infinitivo ('eu gostaria'). Ao utilizar-se dessas formas, o falante não está realmente pedindo licença para ou comunicando seu desejo de expressar sua opinião, pois que ele o fará de qualquer maneira. Em várias ocasiões, tais formas são apenas prólogos que simulam um pedido de permissão ou um distanciamento por parte do falante e, por esse motivo, consideramo-las como exemplos da estratégia use formas convencionalizadas. Como exemplos, podemos citar as ocorrências:

ich darf zunächst sagen (Herr Heizler) sie sagen wir stünden vor schweren Auseinandersetzungen innerhalb der SPD. das ist nicht richtig [...] (COA1) 
ich möchte nur ausdrücklich sagen $+g+$ das die Unfallrettung keine sekundäre Frage ist [...] (TRA45)

Alguns autores chegam a considerar a forma möchten ("gostariam", forma do Konjunktiv do verbo mögen, 'gostar') como um verbo específico (cf. ÖHLSCHLÄGER, 1989: 181s), sendo que ENGEL lhe atribui inclusive um traço de "polidez distanciada":

mögen - significado principal: 'ter o desejo de', 'fazer com prazer': neste sentido, usa-se para o presente principalmente a forma möchte, antigamente, uma forma de Konjunktiv II que, no entanto, perdeu completamente seu sentido estrutural de 'hipotético' e apenas possui um traço adicional de 'polidez distanciada'. (ENGEL, 1988: 466$)^{28}$

Este enfoque da forma "möchten" aponta fortemente para o caráter idiomático de expressão de polidez de que a forma se revestiu na língua alemã atual.

As próximas quatro estratégias formais referem-se à estratégia de segunda ordem denominada não presuma/imponha: negocie o grau de certeza, a qual pressupõe a negociação, entre o falante e o interlocutor, do grau de certeza das afirmações, ou seja, o gerenciamento das relações epistêmicas, dentro das quais distinguem-se diversos graus de segurança (Verläßlichkeit) e responsabilidade frente ao enunciado. Segundo LYONS,

[...] epistimic logic deals with the logical structure of statements which assert or imply that a particular proposition, or sets of propositions, is known or believed (LYONS, 1977: 793).

O mesmo autor afirma ainda haver algumas diferenças nos usos filosófico e lingüístico do termo "epistêmico". ÖHLSCHLÄGER (1989: 28) refere-se às relações epistêmicas como relativas a um conceito de modalidade que expressa "uma atitude do falante com relação à existência de um conteúdo, o grau de certeza do falante sobre a existência de um conteúdo" $^{29}$. Desse modo, gerenciando a expressão de tais relações, o falante pode relativizar o grau de certeza de suas afirmações e diminuir a

\footnotetext{
28 mögen - Hauptbedeutung: 'den Wunsch haben', gerne tun': In dieser Bedeutung wird heute für das Präsens vorwiegend die Form möchte verwendet, eine einstige Konjunktiv-II-Form, die aber die frühere strukturelle Bedeutung 'hypothetisch' völlig verloren hat und lediglich über ein zusätzliches Merkmal 'distanzierte Höflichkeit' verfügt. (ENGEL, 1988: 466).

${ }_{29}^{2}$ [...] eine Einstellung des Sprachers hinsichtlich des Bestehens eines Sachverhalts ausdrücken, Grade der Gewißheit des Sprechers, daß ein bestimmter Sachverhalt besteht (ÖHLSCHLÄGER, 1989: 28).
} 
imposição de sua opinião ao interlocutor. Tal gerenciamento pode ser realizado através de várias estratégias formais, sendo que, a seguir, apresentamos aquelas efetivamente utilizadas em Dissensões no corpus da pesquisa.

\subsection{Relativize a própria opinião}

O falante pode manipular as relações epistêmicas, por exemplo, utilizando-se de expressões correspondentes a um determinado grau de certeza menor do que aquele que realmente sente ser o correto para com a sua afirmação. No corpus da pesquisa, tal gerenciamento das relações epistêmicas na expressão da Dissensão ocorreu principalmente através do uso de hedges e de expressões de opinião pessoal.

\section{A realização lingüística da estratégia "Relativize a própria opinião"}

\section{i) hedges}

O termo hedges surgiu em um artigo de George LAKOFF intitulado "Hedges: a study in meaning criteria and the logic of fuzzy concepts", no qual o autor estuda "palavras cuja tarefa é tornar as coisas mais difusas ou menos difusas". Os hedges, segundo ele, são modificadores de predicados, "mas de um tipo que não foi estudado anteriormente pela semântica formal, pois seus efeitos só podem ser descritos em termos de funções de pertença para conjuntos (sets) difusos" (cf. G. LAKOFF, 1972: 195).

Os hedges modificam os pressupostos exigidos para que um certo predicado seja considerado aplicável ou não. Veja-se como exemplo o hedge inglês in essence, utilizado nas seguintes sentenças:

a) A robin is a bird ('um pintarroxo é um pássaro') - verdadeiro.

b) $A$ chicken is a bird ('uma galinha é um pássaro') - falso

c) A bat is a bird ('um morcego é um pássaro') - falso 
a1) In essence, a robin is a bird ('essencialmente, um pintarroxo é um pássaro') - verdadeiro

b1) In essence, a chicken is a bird ('essencialmente, uma galinha é um pássaro') - verdadeiro)

c1) In essence, a bat is a bird ('essencialmente, um morcego é um pássaro') - falso.

Nos exemplos acima, o hedge in essence (essencialmente) modificou os pressupostos que, normalmente, impedem que uma galinha seja considerada um pássaro, tornando o conceito mais difuso, porém, ainda não o suficiente para permitir que um morcego seja enquadrado na mesma acepção. No entanto, isso pode ainda ser conseguido com o uso de outro hedge, como em:

c2) In a manner of speaking, a bat is a bird (de certo modo, um morcego é um pássaro) - verdadeiro ou, pelo menos, aceitável.

(cf. G. LAKOFF, 1972: 197)

Devido a essa capacidade de modificar a posição de predicados em relação a uma determinada escala, os hedges permitem que a noção de pertença atribuída a certos atos ou contribuições lingüísticas seja manipulada no sentido de atenuá-la ou amplificá-la. Robin LAKOFF, em seu artigo de 1973, cita os hedges como uma maneira de dar opções ao interlocutor, assim atendendo à sua segunda regra de polidez, dê opções (veja item 1.2.3 do capítulo I):

$R[$ ule]2 says: 'Let $A$ [the interlocutor] make his own decisions - leave his options open for him'. [...] So certain particles may be used to give the addressee an option about how he is to react: some of these particles (hedges) have been discussed by G. Lakoff (1972). (R. LAKOFF, 1973: 299)

Desde o artigo de G. LAKOFF, vários autores têm estudado hedges e outras expressões que têm como característica guiar o interlocutor no seu entendimento da afirmação do falante. Embora G. LAKOFF pareça considerar os hedges como uma classe de palavras (cf. comentário de FRASER, 1980: 344), BROWN \& LEVINSON citam uma definição mais abrangente, apresentando-os como "partícula, palavra ou sentença que modifica o grau de pertença de um predicado ou sintagma nominal em um grupo, dizendo de sua 
pertença que ela é parcial ou verdadeira apenas sob certos aspectos, ou mais verdadeira e completa que poderia ser esperado" (op.cit., p.150). CASTILHO \& CASTILHO (1996), em seu estudo sobre advérbios como marcadores modalizadores no português, refundiram o termo hedges como "marcadores modalizadores delimitadores", explicando o termo da seguinte maneira:

[...] os advérbios Delimitadores estabelecem as condições para o entendimento de uma sentença ou de seus constituintes, restringindo o âmbito da informação veiculada. Esses advérbios, por assim dizer, "controlam" a descodificação da mensagem, passando ao interlocutor instruções de como ele deve acionar os mecanismos lingüísticos da significação. [...] Ao restringir o âmbito da informação veiculada pela proposição, os Delimitadores geram dois efeitos de sentido: circunscrevem P a uma perspectiva dada pelo falante ou a um determinado domínio do conhecimento, convencionalizado pela comunidade. (CASTILHO \& CASTILHO, 1996: 246s.)

Desse modo, utilizando-se de hedges (ou Delimitadores), o falante pode restringir ou estender os limites que o interlocutor deve utilizar para avaliar as contribuições do falante à interação, tornando tais afirmações mais ou menos maleáveis e, por conseguinte, mais ou menos conflitantes com as opiniões do interlocutor.

No corpus desta pesquisa, encontram-se vários exemplos do uso de hedges para gerenciar o grau de imposição da opinião do falante sobre o interlocutor durante a Dissensão, como em:

obwohl sie praktisch abhängig ist vom Kreislauf der Mutter und in der nur: in der Mutter existieren kann... (ABO7)

kann man das sagen die Auseinandersetzungen sind abgeschlossen? in einem weiteren Sinne meine ich (COA2)

$+g+$ sie sprachen von Laienarbeit und von dem Appell, der möglicherweise ergehen sollte $+g+i$ ich sehe darin auch eine gewisse (ja) Zudeckung von Problemen, denn sehen sie, wer wird dann wahrscheinlich mitarbeiten [...] (MEN13)

ich kann nur sagen, das ist der praktische und auch nach meiner Überzeugung grundsätzliche Effekt dessen... (COA31) 
A estratégia relativize a própria opinião consiste exatamente em diminuir o grau de imposição de sua opinião ao interlocutor. Como apresentado anteriormente, o uso de hedges é uma das possibilidades de sua realização, ao permitir a negociação dos critérios que norteiam o entendimento do interlocutor a respeito da contribuição do falante. Outra possibilidade de realização desta estratégia é o uso de expressões que aqui denominamos atenuadores.

\section{ii) atenuadores}

Dentro de sua discussão sobre hedges, BROWN \& LEVINSON aludem à existência de expressões que denominam strengtheners e weakeners, as quais, respectivamente, enfatizam ou suavizam os conteúdos que modificam, sendo que "de um modo ou de outro, indicam algo a respeito da adesão do falante com relação ao que ele está dizendo e, assim, modificam a força ilocucional" (cf. BROWN \& LEVINSON, 1978: 152). Tais noções são retomadas no estudo de HOUSE \& KASPER (1981) sobre o que denominam "marcadores de polidez" em inglês e alemão. Às páginas 166 a 170, as autoras apresentam dois grupos de "marcadores modalizadores" (modality markers): os intensificadores (upgraders) e os atenuadores (downgraders), que correspondem, em seu uso, às expressões apontadas por BROWN \& LEVINSON. Esses dois grandes grupos sub-dividem-se em outros menores, sendo que, entre os atenuadores, encontram-se listados os hedges propriamente ditos.

A noção de atenuação deriva principalmente dos trabalhos de FRASER, o qual aponta para a possibilidade de que procedimentos de atenuação sejam utilizados para a polidez (cf. FRASER, 1980: 344). ROSA (1992), em seu trabalho sobre "marcadores de atenuação", utiliza a noção de "marcadores", a qual, em português, tem sido bastante desenvolvida em diversos trabalhos sobre o português falado. Porém, os procedimentos de atenuação não se restringem aos elementos que são considerados marcadores, como aponta Rosa em sua revisão de sua literatura sobre atenuação:

Qualquer que seja a definição de atenuação [...] logo se observa que ela inclui uma enorme variedade de meios ou procedimentos de atenuação. Alguns desses procedimentos podem ser considerados marcadores conversacionais, pois correspondem às margens de uma unidade discursiva [...] e a formas lingüísticas de recorrência e fixidez considerável [...]. Serão chamados então de marcadores de atenuação. Os procedimentos de atenuação que não atendem aos critérios 
frisados acima serão citados, no decorrer do trabalho, apenas como exemplo de diferentes tipos de atenuação lingüística (RosA, 1992: 30s.).

Nosso estudo não se restringe, como o de RosA, a tais elementos, mas sim, desejamos apontar todas as possibilidades de uso de atenuação para o Trabalho da Face. Por esse motivo, não utilizaremos aqui os termos "marcadores modalizadores" (CASTILHO \& CASTILHO, 1996; SiMÕES, 1997) ou "marcadores de atenuação" (RosA, 1992), preferindo o termo mais genérico atenuadores. Também iremos nos abster de uma classificação dos atenuadores, por não ser este o objetivo da presente pesquisa. Uma interessante contribuição ao tema em português e alemão é o trabalho de SIMÕES (1997). Iremos apenas apontar de que maneira tais elementos relativizam a contribuição do falante.

No corpus da pesquisa, encontramos vários exemplos de uso de atenuadores para a realização da estratégia relativize a própria opinião. Os atenuadores podem atuar sobre o grau de adesão do falante à sua contribuição, como nos exemplos:

(ja) aber $+g+i c h$ mein man sollte vielleicht viel mehr andere Menschen beobachten ständig ihre Reaktionen irgendwie sehen und es auch auswerten, daß man nicht so schnell zu Vorurteilen kommt... (MAE36)

$+g+$ sie sprachen von Laienarbeit und von dem Appel, der möglicherweise ergehen sollte $+g+i c h$ sehe darin auch eine gewisse (ja) Zudeckung von Problemen, denn sehen sie, wer wird dann wahrscheinlich mitarbeiten [...]? (MEN13)

wenn politische Gründe sein sollten, was wir wirklich nicht wissen, was wir als eine Möglichkeit $+g+$ aber nicht vielleicht nicht einmal als eine Wahrscheinlichkeit nennen können [...] (ULB1)

Podem também representar o estado de coisas (state of affairs) constante da proposição como tendo um grau menor que aquele que o falante julga ser o correto (cf. HOUSE/KASPER, 1981: 167) :

ich wehre mich ein wenig dagegen, daß hier nun gleich hier so eine Verfremdung hineinkommt...(ALM6)

(ja) ich weiß nicht, ob nicht vielleicht doch Ulbricht $+g+$ nicht nur menschlich sondern auch politisch etwas unbequemer und schwerer zu handhaben war für die Parteiführung in Moskau [...] (ULB4)

(ja) entschuldigen sie aber erst muß ich sie mal ein kleines bißchen berichtigen. [...] (RDA2) 
Atenuadores podem também ser usados para diminuir o teor de agressividade implícito na ilocução (cf. ibidem, p. 167), como em:

(ja) entschuldigen sie aber erst muß ich sie mal ein kleines bißchen berichtigen. sie sagten wir haben die Ernte in die Scheunen gefahren. das is das trifft für unsere Landwirtschaft heute wohl doch nich mehr zu [...] (RDA2)

(eine Sekunde) das bestreite ich. das bestreite ich einfach. das müssen sie mir erst einmal beweisen. (GUE51)

[...] sie sehen also, daß nach wie vor die Hauptunfallursache eben beim Autofahrer wohl selbst zu suchen ist. und das bedarf jahrelanger Arbeit durch Erklärung [...] (TRA28)

Devido a essa minimização da imposição, respeitando, assim, a validade da opinião do interlocutor, o uso de hedges e atenuadores é normalmente considerado uma Estratégia de Compensação Negativa. Porém, conforme descrito anteriormente nos itens 3.2.2.2.1.2 - evite discordância: relativize a opinião do interlocutor e 3.2.2.2.2 - busque concordância: relativize a própria opinião, hedges e atenuadores podem ser usados também em Estratégias de Compensação Positiva.

\section{iii) expressões de opinião pessoal}

As relações epistêmicas foram definidas no item 3.2.2.2.1.2 como o grau de contingência atribuído pelo falante quanto à existência ou à validade de um conteúdo. Através do uso de determinadas expressões lingüísticas, o falante pode salientar o fato de que a opinião que apresenta durante uma Dissensão é completamente pessoal, deixando ao interlocutor uma "saída honrosa": este último pode decidir se aceita a contribuição do falante, admitindo assim a Dissensão, ou se a considera apenas como a expressão de uma opinião pessoal, que não invalida a sua própria, apesar de discordante. No corpus da pesquisa, tais expressões constituem-se principalmente no uso dos verbos glauben, meinen (crer, acreditar) e finden (achar) na primeira pessoa do singular, mas também há ocorrências do verbo fürchten (temer) e das expressões halten für (considerar como) e der 
Meinung sein (ser da opinião), também na primeira pessoa do singular, como mostram os exemplos a seguir:

(ja) ich mein sie haben vorhin gesagt, daß Ehe und Familie wahrscheinlich schädlich sind. ich glaub, das kann man nicht so einfach sagen $+g+$ ich glaube es liegt vor allen viel dran, daß die Eltern sich um ihre Kinder kümmern (MAE24)

das find ich unerträglich, wenn wir nicht mehr $+g+$ wenigstens $n$ bißchen rumlaufen dürfen. das ist immer das Problem (TRA68)

ich halte die Bezeichnung nationaler Notstand und und finsteres Mittelalter für übertrieben und spektakulär... (MENI)

darüber hinaus bin ich aber der Meinung, daß das nun nicht: dem einzelnen Pfleger und dem einzelnem Arzt anzulasten ist, sondern, daß man wirklich die Institution Landeskrankenhaus-heute untersuchen тuß... (MEN19)

... ein Bataillon von Leuten ttt - lacht- ttt von Leuten, die das nun verwalten und ordnen wollen. Und am Schluß haben wir zu den vielen Institutionen noch eine mehr. $+g+$ und ich fürchte diese diese ganze Sache auch wie mit dem Föderalismos... (TRA10)

Tais expressões recebem diversas denominações: "verbos parentéticos" (FraSER, 1980: 348), "verbos epistêmicos" (CASTILHO apud RosA, 1992: 45) e "marcadores de opinião: expressões verbais" (RoSA, 1992: 61). BROWN \& LEVINSON (1978: 169), por sua vez, consideraram-nas como um hedge endereçado à Máxima da Qualidade. Preferimos a denominação expressões de opinião pessoal para acentuar o caráter de expressões semi-convencionalizadas, destinadas a marcar a opinião pessoal do falante, evitando, assim, a imposição. Por outro lado, a denominação também marca a distinção entre tais expressões e os hedges propriamente ditos, os quais se referem a categorias de objetos ou qualidades consideradas comuns a um determinado grupo social, e não próprios do falante, como as expressões de opinião pessoal.

\subsection{Evite afirmações: faça perguntas}

Outra possibilidade de se atender à segunda regra de polidez de Robin LAKOFF, dê opções, é a de apresentar a Dissensão sob a forma de uma pergunta. Dessa maneira, o falante delega, mesmo que apenas 
aparentemente, ao interlocutor, a decisão de entender sua pergunta como uma Dissensão ou não, como no seguinte exemplo:

[...] aber ich glaube, da kommen wir (Dieter Göbel) auf ein Grundproblem des Fernsehens, denn $+g+i$ ch glaube man müßte einmal zuerst die Frage stellen kann der Film der politische Filmbericht [...] heute das Abstrakte was in der politischen Aussage ja doch zu einem guten Teil immer noch drinliegen muß, kann er es wirklich ausdrücken? [...] (MOD4)

\section{A realização lingüística da estratégia "Evite afirmações: faça perguntas"}

No item 3.2.2.4.3 das Estratégias de Compensação Positiva, tratou-se das perguntas negativas como um meio de pressupor as atitudes do falante. Por outro lado, o uso de perguntas para expressar uma Dissensão está de acordo com a segunda regra da polidez de Robin LAKOFF, segundo a qual deve-se sempre dar opções, mesmo que pro forma, ao interlocutor. Quando Dissensões são expressas sob a forma de perguntas, cabe ao interlocutor, ao menos aparentemente, decidir se o falante o está contradizendo ou apenas solicitando-lhe maiores esclarecimentos. A formulação das perguntas está sujeita ao co-texto no qual se inserem, sem que possamos identificar quaisquer elementos lingüísticos específicos para a formulação de perguntas utilizadas como estratégias de Trabalho da Face na expressão da Dissensão.

\subsection{Gerencie o grau de realidade}

Do mesmo modo que o gerenciamento da dêixis temporal, através do uso do presente histórico e do aspecto inacabado, pode aproximar o falante e o interlocutor, conforme descrito no item 3.2.2.4.4 - intensifique o interesse: aproxime o interlocutor, o uso do modo subjuntivo (em alemão: Konjunktiv) pode distanciar o falante do FTA, no nosso caso, a Dissensão.

Segundo FIORIN (1996: 226s.), o sistema de tempos pode ser subvertido para criar efeitos de sentido, os quais, entretanto, estão subordinados às categorias semânticas de aproximação vs. distanciamento: 
Num primeiro nível de concretização, essa categoria produz três outras: uma para os efeitos de sentidos temporais stricto sensu: conjunção vs. deslocação; outra para os efeitos de sentido modais: realidade vs. virtualidade; outra para os efeitos de sentido aspectuais: inacabado vs. não-começado. (ibidem, p. 226)

Em um esquema à página 227 da obra citada, estão sintetizadas as diversas possibilidades de criação de efeitos de sentido a partir destas três sub-categorias. Como nem todos os possíveis desdobramentos constantes do esquema são importantes para nossa pesquisa, optamos por simplificálo. A grossso modo, as possibilidades de gerenciamento das categorias temporal propriamente dita, aspectual e modal organizam-se da seguinte maneira, dentro de um contínuo, para a criação de efeitos de aproximação ou afastamento:

1) temporal: concomitância - anterioridade - posterioridade

2) aspectual: $\quad$ inacabado - acabado - começado - não-começado

3) modal: $\quad$ real $\quad$ virtual

aproximação <--_---_----->afastamento

Através do gerenciamento da categoria modal, o falante pode, portanto, simular um afastamento em relação à Dissensão, apresentando-a como apenas virtual e deixando ao interlocutor, ao menos pro forma, a possibilidade de ignorá-la.

No corpus da pesquisa, encontram-se diversas ocorrências do uso desta estratégia. É importante observar que este uso do Konjunktiv é por vezes concomitante ao uso dos verbos modais. Um exemplo do uso concomitante das duas estratégias é o seguinte:

aber ich glaube, da kommen wir (Dieter Göbel) auf ein Grundproblem des Fernsehens, denn $+g+i$ ch glaube man müßte einmal zuerst die Frage stellen kann der Film der politische Filmbericht [...] (MOD4)

\section{A realização lingüística da estratégia: "Gerencie o grau de realidade"}

O gerenciamento do grau de realidade atribuído à Dissensão, apresentando-a como apenas virtual e minimizando, assim, uma possível ameaça à Face, foi realizado no corpus através do uso do Konjunktiv, sendo a forma mais utilizada a perífrase verbal composta do verbo auxiliar 
werden no Konjunktiv (würde) e verbo principal no infinitivo, à exceção do verbo sein e dos verbos modais, para os quais foi usada a forma sintética. Entre as ocorrências do uso desta estratégia encontram-se os seguintes exemplos:

$+g+$ politischen Sog würde ich sagen, nicht politischen $+g+$ Druck (ja?) $+g+$ (ALE13)

(Herr Prof. Heer) ich würde ihnen $d a+g+$ sie verteidigen so sehr die Frau und ich möchte von daher als Frau dazu Stellung nehmen. ich würde ihnen also ganz entschieden widersprechen, was die Personenwürde der Frau angeht. die sehe ich zum Beispiel völlig anders ... (ABO20)

so selbstverständlich ist das nicht, denn sonst wären schwierige Töchter keine schwierige Töchter (MAE33)

aber ich glaube schwerfälliger als der bisherige könnte es gar nicht werden [...] (EXT11)

Ich würden denselben Standpukt vertreten, nur habe ich diese Bedenken und dann gleich auch Befürchtungen, daß wir nur: das Negative bringen [...] ich glaube auch diese positiven Ansäzte sollte man einmal sagen (MEN10)

A estratégia de segunda ordem denominada não coaja o interlocutor realizou-se, no corpus da pesquisa, através de duas estratégias formais que apresentamos a seguir.

\subsection{Minimize a imposição}

Se o falante não pode evitar a imposição de sua opinião ao interlocutor, ele pode ao menos tentar minimizá-la através de expressões que visam a alertar este último de que a Dissensão não deve ser entendida como um ato potencialmente ameaçador à sua Face, como no seguinte exemplo, no qual o falante avisa que "quer apenas chamar a atenção da interlocutora" para as razões que fazem com que ele discorde dela:

$+g+($ Frau ...) ich wollte sie nur darauf aufmerksam machen, $+g+d a \beta+g+$ eine (ja) [...] Mark mehr für Autofahrer oder daß sie schlechthin den Autofahrer nicht mit dem Hund vergleichen können [...] (TRA53) 


\section{A realização lingüística da estratégia "Minimize a imposição"}

No corpus da pesquisa, observou-se como principal realização lingüística o uso da partícula nur ("apenas, somente") associada ao verbo sagen ("dizer"). A partícula nur também pode ser substituída ou complementada por outras expressões de minimização, como ganz kurz, ein kleines bißchen. Desse modo, o falante dá à sua Dissensão um caráter mais brando, como o de um comentário, minimizando a imposição. Em RosA, encontra-se um procedimento semelhante no que a autora denomina "marcadores prefaciadores de opinião". Ao comentar um dos exemplos de seu corpus, a autora comenta que tal marcador "anuncia a expressão de um ponto de vista diferente ao mesmo tempo que remete a um quadro cognitivo tranquilizador para o interlocutor [...]: trata-se de uma opinião" (RosA, 1992: 64ss.), como no seguinte exemplo de nosso corpus:

(na ja) [...] ich möchte ihm nur sagen das Problem $+g+$ ist keines, das jetzt diese Bundesregierung erstmallig vor sich sieht... (TRA30)

O mesmo procedimento está por trás de outras ocorrências, nas quais são utilizados verbos como aufmerksam machen, hinweisen, bezweifeln etc., menos ameaçadores para a Face do interlocutor, por caracterizarem atitudes menos radicais que a discordância total, como nos exemplos a seguir, nos quais berichtigen ("retificar") e mißverstehen ("entender mal") são utilizados ao invés de afirmar cabalmente que o interlocutor está errado:

(ja) entschuldigen sie aber erst muß ich sie mal ein kleines bißchen berichtigen. sie sagten wir haben die Ernte in die Scheunen gefahren. das is das trifft für unsere Landwirtschaft heute wohl doch nich mehr zu [...] (RDA2)

[...] und wenn ich auf die Laien zurückkommen darf, so möchte ich nur hinweisen auf die Vereine [...] daß auch das: ein Vorurteil ist, daß etwa die Gesellschaft gar nichts von ihren psychischen Kranken wissen wollte... (MEN16)

(liebe liebe gnädige Frau) sie mißverstehen mich ja völlig [...] (ABO23)

A minimização da Dissensão como tal pode também ocorrer de forma ainda mais explícita, como no seguinte exemplo, no qual o falante caracteriza a sua opinião como "especulação": 
(ja) ich weiß nicht, ob nicht vielleicht doch Ulbricht $+g+$ nicht nur menschlich sondern auch politisch etwas unbequemer und schwerer zu handhaben war für die Parteiführung in Moskau [...] das sind auch: Spekulationen. wir wissen auch nicht, aber er hat da eins $+g+(U L B 4)$

\subsection{Dê deferência}

Através da estratégia dê deferência, o falante demonstra que reconhece, em algum aspecto, a superioridade do interlocutor. Dessa maneira, implica que qualquer ato do falante que eventualmente possa ser danoso às Faces não será muito ameaçador.

A forma mais comum de demonstrar deferência é provavelmente a formulação explícita de pedidos e agradecimentos. Dessa maneira, o falante reconhece o poder ou capacidade do interlocutor e, ao mesmo tempo, mostra-se humilde, captando a simpatia do interlocutor.

Segundo BROWN \& LEVINSON, esta estratégia tem dois lados: em um, o falante eleva o interlocutor frente a si mesmo; no outro, o falante se diminui frente ao interlocutor. Ao minimizar suas capacidades e a importância que atribui às suas opiniões, o falante minimiza também a ameaça que sua Dissensão poderia parecer ao outro.

\section{A realização lingüística da estratégia "Dê deferência"}

A formulação explícita de pedidos realiza-se muitas vezes através da expressão bitte (por favor) - segundo DUDEN (1983: 204), uma abreviação de ich bitte ('eu peço') que se cristalizou em uma forma de polidez. Outra possibilidade é o uso do verbo dürfen ('permitir') em perguntas, de modo a solicitar permissão.

A expressão bitte e os verbos bitten e dürfen, este último sempre em perguntas, foram as formas utilizadas no corpus, como no seguinte exemplo:

aber aber zitieren sie doch bitte nich Herrn Speer (GUE43)

ich gebe zu, daß wir natürlich ein Vielzahl von Problemen [...] noch gar nicht abgeschnitten haben. [...] ich bitte sie auch diese Überlegungen mit einzubeziehen. [...] (TRA29)

darf ich mal den den den Gegensatz rauskehren? Es gibt ja auch einen Nebenbuhler (ALM11) 
darf ich etwas zum Begriff Leibesfrucht sagen? ich habe diesen Ausdruck nich gebraucht, sondern ich habe gesagt... (ABO18)

Quanto a agradecimentos, há apenas uma ocorrência no corpus:

ich danke (Herr Heer) (also) $+g+$ behalten sie ihren Atem für die nächste Runde. (ABO10)

No que se refere à diminuição das capacidades do falante frente ao interlocutor e à elevação deste último, encontramos no corpus da pesquisa duas ocorrências do primeiro tipo e três do segundo, as quais apresentamos a seguir.

Neste dois primeiros exemplos, os falantes ressaltam a possibilidade de não terem entendido ou analisado corretamente os fatos que sustentam sua argumentação, apresentando-se, assim, como vulneráveis frente ao interlocutor. No primeiro exemplo, o falante apresenta explicitamente a possibilidade de erro (ich $+g+$ [kann] mich da irren) e introduz a possibilidade de falha por sua parte através do advérbio vielleicht. Em ambos os exemplos, encontra-se uma oração subordinada condicional, introduzida pela conjunção wenn, apresentando as condições para que sua contribuição seja válida:

(ja) ich meine doch: (ich + g+ mich da irren) (vielleicht habe ich das vor Honecker nicht genau genug beobachtet, das eine Verschärfung darin liegt nämlich in den Adjektiven [...] so: habe ich bisher noch nicht gehört. das wäre, wenn ich recht habe und nichts überhört hatte, dann eben doch eine Verschärfung... (ULB14)

insofern als $+g+$ wenn ich die Untersuchungsergebnisse der beiden Hamburger Sexualwissenschaftler Volkmar Sigusch und Gunther Schmidt richtig verstanden habe, dann geht aus den Fragen an bis zu 17 Jahre alten Mädchen und Jungen eindeutig hervor, daß beide Geschlechter mit geringen Prozentunterschieden [...] genau das gleiche sexuelle Bedürfnis nach dem anderen Partner haben. (SEX4)

No terceiro exemplo, a falante apresenta sua resposta como "relativamente boba", minimizando sua importância para a interação:

[warum ist sie froh, wenn die Eltern nicht zu Haus sind?] ich kann ihnen eine relativ dumme Antwort darauf geben. das geht bei mir nich etwa so, daß ich dann irgendwelche Freunde empfangen will oder so [...], sondern [..] daß ich sage (ach) (wie schön) ich kann mal lange Fernsehen gucken... (MAE28)

RosA refere-se a expressões constantes dos dois primeiros exemplos como "marcadores de rejeição", que correspondem aos disclaimers de 
FRASER. Comentando exemplos do seu corpus, a autora afirma que um marcador de rejeição

[...] atenua [..], nomeando uma possível falha do locutor enunciador (não saber). Ao nomeá-la, o locutor elimina de antemão, ao menos determinadas objeções de seu interlocutor, como críticas por não saber ou por se enganar. Mas além disso, tanto o marcador em questão quanto os demais mencionados exprimem, também, a incerteza do locutor enunciador a respeito do que foi dito (ROSA, 1992: 57s.).

Concordamos que o uso de tais expressões exprima incerteza por parte do falante, mas não achamos que esse seja necessariamente o caso em todas as suas ocorrências. No segundo exemplo apresentado anteriormente, o falante parece estar bastante seguro sobre sua citação do estudo, e o efeito conseguido é o de modéstia. Porém, o uso de tal estratégia certamente atua de modo preventivo, evitando que o falante se apresente como categórico e infalível de modo que, ao mostrar-se vulnerável, o falante capta a simpatia e compreensão do interlocutor, ao mesmo tempo que evita possíveis correções por parte do mesmo.

Uma terceira possibilidade de realização da estratégia dê deferência é o uso de termos honoríficos. No corpus da pesquisa, encontramos os termos Dame e gnädige Frau, embora este último já tenha uma conotação ligeiramente ultrapassada:

[...] erstens die junge dame sagte sie möchte nicht heiraten, sie möchte selbständig sein. [...] (MAE37)

darf ich darf ich folgendes sagen? (gnädige Frau) wir sind auch: dagegen. (TRA52)

(liebe liebe gnädige Frau) sie mißverstehen mich ja völlig [...] (ABO23)

Não consideramos aqui como casos da estratégia dê deferência as ocorrências dos termos Herr/Frau/Dr. seguidos do sobrenome, pois, na Alemanha, esta é a forma normal de tratamento em situações formais para pessoas que não são íntimas. Pelo contrário, há apenas um caso no qual as pessoas se tratam pelo primeiro nome, no inquérito MODERADORES.

A terceira estratégia de segunda ordem utilizada pelos falantes para reparar uma Dissensão através da Compensação Negativa é comunicar a vontade de não impingir suas opiniões ao interlocutor. No que se refere à 
Dissensão em nosso corpus, tal meta procurou ser atingida através das estratégias formais apresentadas a seguir:

\subsection{Afastamento pessoal}

Assim como no item 3.2.2.4.3 - crie/pressuponha pontos comuns, o falante manipulava, através da escolha de formas verbais e adverbiais adequadas, a distância entre ele e o interlocutor, buscando a aproximação, o mesmo pode ser feito com a intenção de dissociar o falante de um ato potencialmente danoso à Face, ou dissociar o interlocutor dos conteúdos que levaram o falante a expressar sua Dissensão. Tal afastamento do falante ou do interlocutor em relação à Dissensão pode ser conseguido através de diversos expedientes lingüísticos. A seguir, apresentamos aqueles utilizados no corpus da pesquisa.

\subsection{Impersonalize: gerencie a dêixis pessoal}

Formulando a Dissensão como se algum outro agente que não o falante, ou ao menos não este sozinho, fosse o responsável por ela, o falante indica sua intenção de, ao menos aparentemente, não impor sua opinião ao interlocutor. Isto resulta em uma série de expedientes que visam a evitar nomear os participantes da interação.No primeiro exemplo a seguir, o uso da voz passiva evita que a falante identifique o interlocutor que emitiu a opinião da qual ela discorda:

[...] ich glaube [...] wir haben jedenfalls versucht: die Richtlinien so zu gestalten $+g+$, daß sie nicht so katastrophal würden, wie uns hier eben erzählt worden ist. (ALE2)

No exemplo seguinte, utilizou-se o pronome indefinido man para desvincular o falante da opinião emitida:

ganz so eindeutig sehe ich das nicht. eins ist richtig. durch den Mauerbau hat die DDR natürlich vermeiden können [...] auf der anderen Seite muß man einem Märchen vorbeugen, daß [...] das ist durchaus nicht der Fall... (ULB22) 


\section{A realização lingüística da estratégia: "impersonalize: gerencie a dêixis pessoal"}

$\mathrm{Na}$ tentativa de afastar-se ou ao interlocutor da difícil situação de Dissensão, os falantes utilizaram-se das seguintes possibilidades para impersonalizar os participantes:

\section{i) $\quad M A N$}

Utilizando-se do pronome indefinido man, o falante pode expressar sua Dissensão como se ela não dependesse de sua pessoa, mas sim, fosse uma Dissensão geral ou exprimisse a opinião de pessoas não nomeadas. $\mathrm{Na}$ DUDEN Grammatik, encontramos a seguinte observação:

O pronome indefinido man abrange noções singulares e plurais e abarca desde a representação do próprio Eu até toda a humanidade. (DUDEN, 1984: 342) 30 $^{30}$

No entanto, examinando-se o contexto das ocorrências, é fácil verificar que man, na realidade, se refere ao falante:

[...] nun zu diesem Vorschlag, wer das finanzieren soll, (also) ich halt von diesem Vorschlag, daß die Autofahrer doch zusätzlich eine Mark dafür bezahlen sollen, davon halte ich nichts, denn man muß sagen, die Autofahrer zahlen bereits genug... (TRA11)

[...] ich bitte sie auch diese Überlegungen mit einzubeziehen. das sind natürlich auch alles Merkmale, die man mit erwähnen muß, die dazu beführen können, daß die Unfälle auf der Autobahn mit vermindert werden. (TRA29)

aber man müßte sagen zunächst Schwerpunkt auf den Verhalten auf den Maßnahmen, die ich sagte, um von vornherein schon Menschenleben zu retten. die zweite Sache ist natürlich, wenn der Unfall passiert ist, die Tätigkeit des Unfallrettungsdienstes. das ist ganz klar. (TRA46)

ich sage man weiß es nicht. aber ich glaube doch, daß die Umwelt immer auf einen jungen Menschen abfährbt (MAE32)

No entanto, o pronome man pode também ser utilizado para designar indiretamente o interlocutor, principalmente em momentos de crítica. Este uso de man como realização da estratégia impersonalize:

\footnotetext{
${ }^{30}$ Das Indefinitpronomen man umfaßt singularische und plurarische Vorstellungen und reicht von der Vertretung des eigenen Ich bis zu der gesamten Menschheit. (DUDEN, 1984: 342)
} 
gerencie a dêixis pessoal foi o mais freqüente no corpus da pesquisa. Nos seguintes exemplos, o contexto deixa claro que man, na realidade, se refere ao interlocutor:

(schön) bis jetzt hat s bei uns auch funktioniert aber man kann nicht sagen... wenn man die Organisation verbessern will, dann kann man nicht kommen und sagen aber dieses Mittel der relativen Mehrheitswahlrechts das ist gegen den Staat überhaupt gerichtet. davon kann doch gar keine Rede sein... (COA18)

[...] ich weiß nicht, ob das immer etwas Gutes ist (nich?) ich will man kann es doch wohl kaum als gut bezeichnen, wenn in ganz bestimmten Ländern eben noch sehr rückschrittliche Tendenzen herrschen. (ALE6)

da muß ich sie unterbrechen (Kollegin). Hypokrates hat davon nichts gesagt (ja?). also man darf den Arztberuf nicht überideologisieren sondern wir müssen tatsächlich auch gesellschaftspolitisch auf dem Stand unseres Wissens sein. [...] (ABO29)

(ja) ich weiß nicht, ob man nun also jetzt also $+g+$ diese Deutung jetzt nun wirklich auf Tischsitten ausdehnen kann, das sind ja schon wieder zwei verschiedene Dinge (nich?) (ALM12)

[...] wenn man sagt von Natur aus, dann macht man eine Annahme darüber, wie Sexualität vor irgendwelchem Lernprozeß in dem Einzelnen eingelegt sei. [...] (SEX6)

\section{ii) Voz passiva}

Através do uso da voz passiva, o falante pode apagar-se como agente de uma Dissensão. No entanto, no corpus da pesquisa, o uso da voz passiva ocorreu principalmente para ocultar o falante frente a uma crítica do interlocutor, como em:

Das wird ja nicht bestritten das wird nicht bestritten. (ABO9)

das ist nie angenommen worden (ULB12)

so war das nicht verstanden (SEX10)

ou para ocultar o interlocutor em situações de crítica por parte do falante, como nos exemplos: 
[...] das ist etwas, was bei anderen Politikern und schon gar bei Honecker $+g+$ nirgends zu sehen war. und ich glaube hier liegt wirklich ein Unterschied $+g+$, der vermerkt werden muß. (ULB16)

$[\ldots]+g+$ es wurde gesagt $+g+$ sie brauchten nicht nach England zu fahren um diese Erfahrung zu machen es gibt in der BR Vergleichbares. es gibt das Vergleichbare nicht: auf der Ebene eines Landeskranken $+g+$ hauses...(MEN11)

Em vista destes resultados, parece-nos possível afirmar que, em situações de Discussão, é considerado mais importante encobrir o participante que é objeto de crítica do que eximir-se da responsabilidade da Dissensão.

Há ainda, em alemão, construções sintáticas que são consideradas como equivalentes à voz passiva. Segundo a DUDEN GRAMMATIK, entre elas encontram-se a forma sich lassen + infinitiv (DUDEN, 1984: 184), que apresenta uma ocorrência no corpus:

der Vorschlag läßt sich nicht verwirklichen. (TRA69)

Também neste exemplo é o interlocutor que é apagado da crítica do falante, ao afirmar que não se pode executar sua sugestão (do interlocutor).

\section{iii) Orações infinitivas}

O uso de construções infinitivas (DUDEN, 1984: 666) também serve para ocultar os participantes da interação, pois os agentes são completamente apagados, como mostram as duas ocorrências do corpus, nas quais também há críticas às contribuições dos falantes:

(na) ich mein den Faschismus auszusparen wär ja völlig falsch (nich?) (ALE11)

(genau) ich wollte also sagen ich würde ganz energisch widersprechen. [...] und das is is is sowieso falsch. und $+g+$ jemand hier bis 25 Jahren nicht zusprechen zu wollen, das er $+g+$ einen Führerschein erhält geht gar nicht. [...] (TRA65) 


\subsection{Apele à autoridade/objetividade}

O falante pode, também, apresentar sua opinião como se ela não fosse totalmente pessoal, mas sim, objetiva, proveniente de ou secundada por instituições ou pessoas idôneas e totalmente desvinculadas tanto do falante como do interlocutor:

[...] jedenfalls gibt es keine Forschungsergebnisse, die $+g+$ bestätigen, was sie glauben. es ist ein Postulat. (SEX3)

(nee) (nein) das kann man aber wirklich nicht sagen, das ist biologisch falsch. (ABO25)

Widerspruch $+g+$ wenn ich $+g+$ (Entschuldigung) wenn ich sage ich glaube doch, daß hier nach den neusten etymologischen Forschungen ein Irrtum vorliegt [...] (ALM10)

insofern als $+g+$ wenn ich die Untersuchungsergebnisse der beiden Hamburger Sexualwissenschaftler Volkmar Sigusch und Gunther Schmidt richtig verstanden habe, dann geht aus den Fragen an bis zu 17 Jahre alten Mädchen und Jungen eindeutig hervor, daß beide Geschlechter mit geringen Prozentunterschieden [...] daß also beide Jungen wie Mädchen der Ansicht sind, $+g+$ beide Geschlechter hätten genau das gleiche sexuelle Bedürfnis nach dem anderen Partner. (SEX4)

(nein) (nein) eine durch Dokumente zu beweisende Version (GUE10)

(Herr Nannen) erstens liegt dem ZDF ein in Bild und Ton ein Interview mit dem von ihnen zitierten Friseur vor [...] in allen Teilen bestätigt, das dies nicht: der Fall ist... (GUE29)

\subsection{Invoque regras gerais}

Levando a estratégia de impersonalização ao extremo, o falante pode invocar uma regra social geral, uma regulamentação, obrigações morais ou fatos externos tidos como incontestáveis como os fatores que o levaram a expressar sua Dissensão para com o interlocutor. Assim, nem o interlocutor sentir-se-á pessoalmente atingido pelo falante, nem este carregará o ônus de provocar tensão na interação. Deve-se notar que o falante pode também apresentar sua própria opinião como se ela fosse aceita como uma regra geral. Um exemplo do uso dessa estratégia no corpus é:

(also) hierzu kann ich nur folgendes sagen. wir sind froh, daß endlich die unterschiedliche Handhabung in den Ländern beseitigt, daß der 
Führerschein $+g+$ bewerber oder -inhaber keinen Eintrag kriegt keinen beschränkenden Eintrag nur deswegen, weil er auf automatik geschult oder geprüft worden ist, denn (schauen sie) es sind zwischen den einzelnen Fahrzeugtypen weit größere Unterschiede als zwischen den Fahrzeugen mit Automatik und +g+ sonst normaler Kupplung... (TRA40)

Embora sem citar as fontes que o levaram à afirmação de que as diferenças entre os diversso tipos de carros são maiores que entre os carros com câmbio normal e automático, o falante a apresenta como se fosse uma regra geral conhecida e incontestável, para expressar sua Dissensão com o interlocutor, que sustentava que pessoas que haviam aprendido a dirigir em carros com câmbio automático não conseguiam adaptar-se ao câmbio convencional.

\section{A realização lingüística da estratégia "invoque regras gerais"}

Nos inquéritos que compõem o corpus, esta estratégia realizou-se principalmente através de afirmações categóricas do falante, algumas calcadas em preceitos morais gerais, como em:

(Herr Nannen) sie dürfen aber nicht die Unwahrheit sagen (GUE7)

ich möchte zunächst sagen davon, daß andere Menschen Unrecht begehen, kann man nicht das Recht herleiten, daß auch wir Unrecht tun sollen... (ABO11)

in der großen oder in einer kleinen oder wo auch immer. Jeder Mensch hat das [Recht auf das eigene Meinung] nicht nur unter Politikern. (COA28)

outras tendo como base o conhecimento type:

[...] kein Mensch wird ja Sportgeräte und Schmuckstücke essen. (ALM25)

[...] niemand macht hat das. mit Hammelkeulen hat man nie Wettbewerbe gemacht [...] (ALM27)

e ainda outras baseadas (tanto quanto se pode verificar) apenas na visão do falante:

[...] dann kann man nicht kommen und sagen aber dieses Mittel der relativen Mehrheitswahlrechts das ist gegen den Staat überhaupt gerichtet. davon kann doch gar keine Rede sein... (COA18) 
[...] ich habe auch Verständnis dafür, daß sie irgendwo Sorgen mit Hunden haben [...] seien sie so freundlich und halten sie das (bitte) auseinander das ist nicht vergleichbar. (TRA53)

(genau) ich wollte also sagen ich würde ganz energisch widersprechen. zunächst darf man überhaupt nicht verallgemeinen (nicht wahr?) und das is is is sowieso falsch. [...] (TRA65)

[...] man kann nicht Verkehrspolitik dadurch betreiben, daß sich nur finanziell Gutgestellte ein Auto leisten kann, das ist kein Weg zu einer vernünftigen Verkehrspolitik. (TRA58)

$\mathrm{Na}$ maior parte das ocorrências, observa-se a utilização do pronome indefinido man, geralmente aliado aos verbos modais können (nicht), dürfen (nicht), müssen e sollen, os quais marcam as opiniões apresentadas como regras gerais de boa conduta válidas para todo o grupo social ao qual os participantes pertencem. Como apontado no item anterior, man pode ser usado para abranger toda a humanidade, prestando-se assim otimamente para apresentar conteúdos como regras gerais dentro da sociedade. A diferença entre o uso de man em regras gerais e na estratégia impersonalize está no fato de que, pelo contexto, fica claro que o falante não se refere apenas a ele próprio ou ao interlocutor como responsáveis ou objetos do conteúdo em questão, mas sim, o estende a todo o seu grupo social, como nas seguintes ocorrências:

[...] das net möglich ist, daß man einfach immer Klappschilder hintut, die man wieder zudeckt, wenn jetzt 2 Stunden z.B. schnell gefahren werden könnte. also das muß man in Kauf nehmen. (TRA7)

(nun) man $+g+$ man man kann nicht als Tochter aus dem Haus gehen und sagen denen zeige ich $s$ jetzt [...] man läßt hinter sich ein bißchen ein Trümmerfeld zurück. man bricht: mit zu Hause. (MAE1)

[...] in kei:nem angelsächsischen in keiner angelsächsischen Demokratie, die nur das sogennante Mehrheitswahlrecht kennt, kann man sagen, daß es eine Existenzfrage gibt des Staates oder eine Gefahr für den Staat besteht. (COA16)

[...] man soll nicht immer gleich nach der Regierung oder Reglementierung schreien [...] (TRA28) 
man darf auch nicht immer an den Kraftfahrer denken, wie Herr Dr. Seehum aber etwas ausschließlich getan hat (TRA32)

[...] das kann man einfach nicht beweisen. daß sie eine Behinderung sind, wenn sie nicht so zügig fahren, wie sie könnten, das steht außer Zweifel. (TRA59)

\subsection{Defocalize os participantes}

Outra possibilidade de afastamento pessoal é apresentar a Dissensão como se ela não fosse dirigida exatamente ao interlocutor. Esta estratégia tem pontos em comum com a estratégia impersonalize: gerencie a dêixis pessoal. Porém, enquanto nesta ainda é possível perceber-se a existência de um agente, mesmo que indeterminado, na estratégia defocalize os participantes estes são, geralmente, completamente apagados através da focalização do resultado de suas ações ao invés de sua participação nelas. Assim, o objeto da Dissensão não é o interlocutor, mas sim, por exemplo suas opiniões, como se as mesmas tivessem uma existência independente da dele, podendo, assim, ser atacadas sem danos à sua Face, como em:

der Vorschlag läßt sich nicht verwirklichen. (TRA69)

no qual a impossibilidade de realização é imputada à própria sugestão, eclipsando totalmente o interlocutor que a havia formulado.

\section{A realização lingüística da estratégia "defocalize os participantes"}

As ocorrências de uso desta estratégia no corpus da pesquisa apresentam uma crítica a uma ação do falante, a qual, no entanto, é apresentada como desvinculada desde último:

ich wehre mich ein wenig dagegen, daß hier nun gleich hier so eine Verfremdung hineinkommt...(ALM6)

mir ist das alles mir ist die Definition zu abrupt und mir ist auch die Interpretation von Herrn Honig zu abrupt. [...] (ALM9)

Widerspruch $+g+$ wenn ich $+g+$ (Entschuldigung) wenn ich sage ich glaube doch, daß hier nach den neusten etymologischen Forschungen ein Irrtum vorliegt [...] (ALM10) 
$+g+$ sie sprachen von Laienarbeit und von dem Appell, der möglicherweise ergehen sollte $+g+$ ich sehe darin auch eine gewisse (ja) Zudeckung von Problemen [...] (MEN13)

(ja) (also) $+g+$ da kann man nur sagen, daß das eine unbewiesene Behauptung ist. [...] (TRA59)

Os casos de Dissensão referente à forma de expressão utilizados de forma estratégica para criticar o comportamento ou as opiniões do interlocutor, conforme explicados no item 2.2.2.1, também podem ser considerados exemplos da estratégia defocalize os participantes, pois a Dissensão parece dirigida à expressão lingüística quando, na realidade, é endereçada às convicções daquele que a utilizou, como nos exemplos a seguir:

ich halte den Ausdrück Zugeständnis für falsch (Herr Heizler)... (COA7)

[...] und unglückliche Verhaltensweise oder falsche Reaktionen, die auch den Irrtum mit einschließt, ist etwas ganz anderes als das, was mir wirklich vorgeworfen worden ist. (COA29)

darf ich etwas zum Begriff Leibsfrucht sagen? ich habe diesen Ausdruck nich gebraucht, sondern ich habe gesagt... (ABO18)

No corpus da pesquisa, encontramos quatro ocorrências que visam a deslocar o foco da Dissensão, afastando-o do interlocutor. Porém, nestes quatro casos, ao invés de focalizar a Dissensão na ação ou no conteúdo apresentado por este último, o falante dirige sua Dissensão a si próprio, colocando-se hipoteticamente na posição do interlocutor e indicando que, em seu lugar, ele agiria de outra maneira, esperando, assim, que o interlocutor entenda que ele é o alvo da Dissensão:

ich möchte auf das Wort Kapitulation zurückkommen dürfen (Herr Heizler) [...] und wenn jemand ich finde den Ausdruck Kapitulation schlecht in jedweder Beziehung so rum gesehen wie auch in dem Bilde, das ich gerade gebrauche [...] so würde ich genauso gut $+g+$ das Bild von der Kapitulation $+g+$ gebrauchen können, wenn wenn das ein angemessenes Wort überhaupt wäre. ich halte es nicht für angemessen. (COA6)

A argumentação de que o falante também poderia utilizar tal imagem, se quisesse, mas não o faz por não julgá-la adequada, indiretamente procura levar o interlocutor a agir de forma recíproca, ou seja, abandonando a imagem em questão. 
(Verzeihung) (Herr Schmidt) jetzt tun sie mir Unrecht. ich: habe hier den

Präsidenten des Bundestages gebeten, ein Schlußwort zu reden. er hat es so gehalten, wie er: es eben für richtig hält. ich würde da doch den Respekt (COA35)

Nesta ocorrência, o falante também afirma que ele, no lugar do interlocutor em tal situação, manteria o respeito pelo presidente, o que ele não estava fazendo, implicando assim sua crítica.

letzteres stimmt. nur die Verantwortung würde ich also nicht abwälzen wollen von denen die (TRA36)

Neste caso, o falante afirma que ele não tentaria eximir as autoridades responsáveis pelo trânsito dos problemas discutidos, ao que o interlocutor apressa-se a retrucar que ele também não tem tal intenção.

aber (Herr Dr. Seehum) wenn ich sie $d a+g+$ unterbrechen darf, dann frage ich mich natürlich, wenn die Mittel vorhanden wären, warum gibt es dann nicht an den an den $+g+$ stark frequentierten Autobahnen... (TRA17)

Esta ocorrência é a única na qual a atitude do falante é apresentada como hipotética. Contudo, o falante dirige a si próprio uma pergunta que só faria sentido se fosse endereçada ao interlocutor, pois o uso do Konjunktiv para reproduzir a afirmação do interlocutor, de que os meios financeiros necessários aos programas de segurança no trânsito existem, deixa claro que o falante não acredita nisso.

Um uso semelhante da primeira pessoa do singular pela segunda do singular ou do plural é apontada por FIORIN, utilizando-se do exemplo de um slogan de campanha eleitoral, no qual os eleitores que o utilizavam, "dizendo $e u$, pensavam em $t u$, na esperança de que todos se reconhecessem como sujeitos" (FIORIN, 1996: 92). Tal gerenciamento da dêixis pessoal seria, segundo ele, uma das possibilidades de emprestar à frase uma função conativa. O Dicionário de Lingüística consigna a "função conativa" como sinônimo de "função injuntiva", pela qual "o falante incita o destinatário a agir de uma certa maneira" (DuBoIs et al., 1995: 346). Assim, utilizando-se desta formulação, na qual se coloca hipoteticamente na situação do interlocutor, o falante visa a levar o interlocutor a agir de acordo com sua sugestão, a qual, por ser diferente do comportamento original do interlocutor, é entendida como Dissensão e crítica.

$\mathrm{Na}$ realidade, estas ocorrências de Dissensão poderiam ser consideradas exemplos de Dissensões off record, pois o interlocutor só 
pode entender as contribuições do falante como Dissensões às suas contribuições através da derivação de implicaturas. BROWN \& LEVINSON inclusive sugerem, como estratégia off record, o procedimento "desloque o interlocutor", que compreende o uso de "indiretas" (cf. BROWN \& LEVINSON, 1978: 231s.). Contudo, a reação dos interlocutores às ocorrências listadas acima é imediata e mostra que tais expedientes são entendidos sempre como crítica, sendo que o falante em nenhum caso tenta eximir-se dessa intenção. Por esse motivo, optamos por considerar, neste estudo, tais ocorrências como Dissensões diretas e casos específicos de realização da estratégia defocalize o participante.

\subsection{Afastamento epistêmico: utilize verbos modais}

No estratégia relativize a própria opinião, o falante gerenciava o grau de certeza e responsabilidade por suas opiniões utilizando-se de expressões correspondentes a um determinado grau de certeza menor do que aquele que ele realmente gostaria de utilizar. Uma outra possibilidade de diminuir o grau de responsabilidade pelas suas contribuições é afastar-se delas, gerenciando as relações epistêmicas através do verbo modal sollen. De acordo com ÖHLSCHLÄGER:

e soll IP significa que uma fonte Q (fornecida pelo contexto) quer/prefere que o conteúdo caracterizado por IP se realize. Q pode ser tanto o falante como também uma outra pessoa ou objeto [...] o fato de que, em tais enunciados, se presuma um maior grau de obrigatoriedade, pode ser atribuído apenas ao nosso conhecimento enciclopédico (1989: 174s.) $)^{31}$

Dessa maneira, o falante atribui a outrem a responsabilidade por contribuições que, na maioria das vezes, são, na realidade, suas, diminuindo o ônus de ser o responsável por uma Dissensão potencialmente perigosa para o bom andamento da interação.

\footnotetext{
${ }^{31}$ e soll IP = eine (vom Kontext gelieferte) Quelle $Q$ will/es vorzieht, daß der mit der IP bezeichnete Sachverhalt eintritt. Dabei kann $Q$ sowohl der Sprecher als auch eine andere Person bzw. ein anderer Gegenstand sein [...] daß bei solchen Äußerungen ein relativ hoher Verbindlichkeitsgrad anzunehmen ist, ist nur auf unser enzyklopädisches Wissen zurückzuführen. (ÖHLSCHLÄGER, 1989:174s.)
} 


\section{A realização lingüística da estratégia "afastamento epistêmico: utilize verbos modais"}

Como apresentado acima, a perífrase formada pelo verbo modal sollen e um verbo principal foi a forma lingüística utilizada para a realização desta estratégia no corpus da pesquisa, como mostram os seguintes exemplos:

(nein) das soll eine objektive Fragestellung sein. (ABO5)

(ja) schwerfällig soll er nich sein (EXT9)

(ja) (also) die Geschwindigkeitsbegrenzungen in Frankreich sind ja zunächst versuchsweise für ein halbes Jahr eingeführt worden auf ganz bestimmten Straßen und $+g+$ nach den Pressemitteilungen soll tatsächlich (allerdings die Zeitraum ist nicht genannt) $+g+$ die $+g+$ die Unfalltoten soll gesunken sein aber der Zeitraum: um wirklich aussagekräftige Ergebnisse zu gewinnen ist zu kurz.[…] (TRA24)

wenn politische Gründe sein sollten, was wir wirklich nicht wissen, was wir als eine Möglichkeit $+g^{+}$aber nicht vielleicht nicht einmal als eine Wahrscheinlichkeit nennen können, [...]. (ULB1)

\subsection{Afastamento temporal: gerencie a dêixis temporal}

Conforme apresentado anteriormente quando explicamos o mecanismo de gerenciamento da dêixis temporal, o tempo passado, mais próximo do pólo de afastamento no esquema apresentado no item 3.2.2.5.4, também pode ser usado para criar um efeito de distanciamento entre o falante e a Dissensão. $\mathrm{O}$ uso do tempo passado é freqüentemente combinado com o de verbos modais, como na forma ich wollte... ('eu queria...'), sendo esta a única realização lingüística desta estratégia no corpus da pesquisa, como mostram as ocorrências a seguir. Nestes casos, fica claro, pelo contexto, que o falante não se refere a algo que ele queria apenas anteriormente, mas sim, a seus desejos e intenções no momento da fala:

das war aber nicht der Kern meiner Frage. ich wollte wissen... (MAE13)

$+g+$ das ist aber ich wollte von ihnen eine ganz präzise Antwort (MAE29)

$+g+($ Frau ...) ich wollte sie nur darauf aufmerksam machen, $+g+d a \beta+g+$ eine (ja) [...] Mark mehr für Autofahrer oder daß sie schlechthin den Autofahrer nicht mit dem Hund vergleichen können [...] (TRA53) 
(genau) ich wollte also sagen ich würde ganz energisch widersprechen. zunächst darf man überhaupt nicht verallgemeinen (nicht wahr?) [...] (TRA65)

\subsection{Indique relutância}

Outra possibilidade de retirar do falante a responsabilidade pela Dissensão é o gerenciamento das relações deônticas. LYONS relaciona o termo deôntico à lógica da obrigação e permissão. Segundo ele, a modalidade deôntica ocupa-se com a necessidade ou possibilidade de fatos executados por agentes moralmente responsáveis (cf. LYONS, 1978: 823). Com relação à Dissensão, o falante pode alegar que foi compelido a expressá-la por razões externas, que se sobrepõem à sua vontade, indicando sua relutância frente a necessidade de discordar do interlocutor.

Um dos casos mais presentes no corpus é quando o falante sinaliza que "foi obrigado" a manifestar-se, mas não diz o que o leva a isso. Tal comportamento é abordado por BROWN E LEVINSON como um "hedge endereçado às estratégias de polidez [...] parecendo significar que aquilo que é dito de modo explícito poderia mais propriamente ter sido dito implicitamente ou nem mesmo ter sido mencionado" (cf. BROWN \& LEVINSON, 1978: 176s). Apesar de entender o raciocínio que levou os autores a classificarem tal tipo de estratégia como o uso de um hedge, consideramos que, ao invés de "criar" uma categoria especial de hedges endereçados à polidez, seria mais racional encarar tais prefácios como indicadores de pretensa relutância do falante, ao ser obrigado a cometer um "atentado" contra as Faces, mesmo contra sua vontade. Assim, casos como:

(ja) entschuldigen sie aber erst muß ich sie mal ein kleines bißchen berichtigen [...] (RDA2)

ich kann nur sagen, das ist der praktische und auch nach meiner Überzeugung grundsätzliche Effekt dessen... (COA32)

são considerados, neste estudo, como exemplos de indicação de relutância por parte do falante. 


\section{A realização lingüística da estratégia "indique relutância"}

No corpus da pesquisa, as indicações de relutância do falante frente à expressão da Dissensão realizaram-se, em sua quase totalidade, pelo uso dos verbos modais müssen (precisar, ser necessário) e können (poder, ser possível), sendo este último sempre seguido das partículas nur (apenas, somente) ou einfach (simplesmente), ambos associados a verbos dicendi, como sagen e berichtigen, entre outros. O falante apresenta a sua expressão da Dissensão como imposta por motivos externos à sua vontade, embora sem nomeá-los, os quais não the deixam alternativa a não ser manifestar-se contra o interlocutor. Em comunicação pessoal, BLÜHDORN chamou-nos a atenção para o fato de que o verbo müssen é também utilizado em alemão para exprimir necessidades corporais que podem ser controladas apenas até um certo ponto (como rir, ir ao banheiro, cuspir - ich mußte lachen; ich muß aufs Klo/spucken), e que tais processos são freqüentemente utilizados como metáforas para uma atividade verbal incontrolada (p.ex.: spuck es aus!), o que também é possível em português (p.ex.: vomitar impropérios). De qualquer modo, mantém-se a conotação de ação que não pode ser contida, mesmo que (possivelmente) contra a vontade do falante naquele momento. Desse modo, o falante presta sua homenagem à Face do interlocutor e pode expressar mais livremente sua Dissensão. A seguir, apresentamos algumas ocorrências constantes do corpus:

(also) hierzu kann ich nur folgendes sagen. wir sind froh, daß endlich die unterschiedliche Handhabung in den Ländern beseitigt [...] (TRA40)

[...] ich war auch dagegen, aber, wenn sie die Hundesteuer $+g+$ hier anführen, dann muß ich sagen die is auch: schon zu hoch... (TRA52)

es steht beispielweise eindeutig fest (insofern da muß ich ihnen (Frau Dr. Brandenburg) widersprechen), $d a \beta[\ldots]$ (ABO17)

(ja) aber ich muß da $+g+$ dem eigentlich entgegenhalten, $+g+d a \beta d a s$ natürlich Ergebnisse sind [...] (MEN18)

aber da... ich muß da noch eine Gegenfrage stellen. sie sagen die Schlagkraft $+g+$ der auswärtigen Kulturpolitik [...] (EXT1)

Por vezes, a estratégia indique relutância é combinada com as estratégias impersonalize: gerencie a dêixis pessoal:

[...] auf der anderen Seite muß man einem Märchen vorbeugen [...] das ist durchaus nicht der Fall... (ULB22) 
(Herr Littmann) dazu muß man sagen das ja noch vor knapp einem Jahr [...] jeden [...] in s Gefängnis gesperrt hat, wenn er in betrunkenem Zustand ein Kraftfahrzeug gelenkt hat. und was war die Folge? die Trunkenheitsdelikte haben nicht: abgenommen... (TRA50)

(ja) (also) $+g+$ da kann man nur sagen, daß das eine unbewiesene Behauptung ist. [...] (TRA59)

ou ainda, em alguns casos, também com a estratégia gerencie o grau de realidade, como na seguinte ocorrência:

aber man müßte sagen zunächst Schwerpunkt auf den Verhalten auf den Maßnahmen, die ich sagte, um von vornherein schon Menschenleben zu retten [...] (TRA46)

Esta combinação de várias Estratégias de Compensação não é exclusiva destes exemplos, sendo um procedimento normal dentro do Trabalho da Face. No item 3.2.2.5.1, referente ao uso de expressões convencionalizadas, apresentamos exemplos deste procedimento:

a) Pode me passar o sal? (estratégia faça perguntas)

b) Poderia me passar o sal?

(estratégias faça perguntas + gerencie o grau de realidade)

c) Você não poderia me passar o sal?

(estratégias faça perguntas + gerencie o grau de realidade + seja pessimista)

BROWN \& LEVINSON e LEECH enfatizam que quanto maior esforço for dispendido na formulação do conteúdo que se quer apresentar como "polido", ou seja, quanto mais "indiretamente" ele for apresentado, tanto maior será o efeito de polidez. Assim, a combinação de diversas estratégias é um recurso comum para acentuar o Trabalho da Face, estando também presente na Dissensão.

Há apenas uma ocorrência da estratégia indique relutância na qual não se utilizaram os verbos modais können e müssen. Nesta ocorrência, o falante manifesta expressamente o seu desejo de não retomar aspectos já abordados na interação, a fim de contestá-los, o que, no entanto, não o impede de fazê-lo:

[...] und $+g+i c h$ meine ich möcht jetzt nicht auf + g+Verschiedenes noch zurïckgehen aber es wird eben hier $+g+$ einzelne Delikte werden herausgegriffen. es wird so getan, als seien das Einzelfälle. ich würde sagen es ist die Spitze eines Eisberges [...] (MEN18) 


\subsection{Peça desculpas}

Outra estratégia que permite sinalizar ao interlocutor que o falante admite estar violando as necessidades de sua Face negativa é um pedido explícito de desculpas pela ameaça contida na Dissensão. Um dos exemplos citados no item anterior também apresenta uma ocorrência do uso desta estratégia para compensar a expressão da Dissensão:

(ja) entschuldigen sie aber erst muß ich sie mal ein kleines bißchen berichtigen $[\ldots](R D A 2)$

\section{A realização lingüística da estratégia "peça desculpas"}

TAGNIN (1989: 57 e 65), seguindo a terminologia de CoulMAS, lista expressões utilizadas em situações de pedidos de desculpas e as classsifica como fórmulas de rotina, formas fixas obrigatórias em determinadas situações ritualizadas.

As ocorrências da estratégia peça desculpas realizam-se, no corpus da pesquisa, através de fórmulas consagradas, como mostram os exemplos:

(entschuldigen sie) die is ja jedenfalls bei uns in den Bundesländern einheitlich. [..] (TRA41)

...Punkte noch hinzu meiner Meinung nach. bitte um Entschuldigung (Herr Höllerer) und $+g+$ der eine is eben, daß es eine Begegnungsstätte für die Ausstrahlungen beider Länder wird... (EXT13)

(liebe liebe gnädige Frau) sie mißverstehen mich ja völlig [...] verzeihen sie, daß ich ...(ABO23)

(Verzeihung) (Herr Schmidt) jetzt tun sie mir Unrecht [...] (COA34)

Widerspruch $+g+$ wenn ich $+g+$ (Entschuldigung) wenn ich sage ich glaube doch, daß hier nach den neusten etymologischen Forschungen ein Irrtum vorliegt $[\ldots]($ ALM10)

(nein) das stimmt leider nicht (nein) (GUE1) 


\subsection{Quadro sinótico da realização lingüística de Estratégias de Compensação Negativa na Dissensão}

\begin{tabular}{|c|c|}
\hline $\begin{array}{c}\text { ESTRATÉGIA DE COMPENSAÇÃO } \\
\text { NEGATIVA } \\
\end{array}$ & REALIZAÇÃO LINGÜÍSTICA \\
\hline $\begin{array}{l}\text { Seja } \\
\text { indireto }\end{array}$ & $\begin{array}{l}\text { formas convencionalizadas: } \\
\text { ich/man weiß nicht; das ist die } \\
\text { Frage; ich darf...; ich möchte... }\end{array}$ \\
\hline Relativize a própria opinião & $\begin{array}{l}\text { hedges; atenuadores; expressões } \\
\text { de opinião pessoal; verbos modais } \\
\text { können, mögen, "dürfte" }\end{array}$ \\
\hline Faça perguntas & formulações individuais \\
\hline Gerencie o grau de realidade & $\begin{array}{l}\text { Konjunktiv: würde + Infinitiv; } \\
\text { forma sintética nos verbos modais, } \\
\text { sein e haben }\end{array}$ \\
\hline Minimize a imposição & $\begin{array}{l}\text { partícula nur; formulações } \\
\text { individuais com verbos e } \\
\text { substantivos relativamente menos } \\
\text { agressivos (berichtigen, } \\
\text { aufmerksam machen, hinweisen; } \\
\text { Spekulationen...) }\end{array}$ \\
\hline Dê deferência & $\begin{array}{l}\text { expressão: bitte; verbo bitten; } \\
\text { perguntas com o verbo dürfen; } \\
\text { expressão: danke; honoríficos: } \\
\text { gnädige Frau, Dame }\end{array}$ \\
\hline $\begin{array}{l}\text { Impersonalize: gerencie a dêixis } \\
\text { pessoal: }\end{array}$ & $\begin{array}{l}\text { man; voz passiva; construção sich } \\
\text { lassen + infinitivo; construções } \\
\text { infinitivas }\end{array}$ \\
\hline Apele à autoridade/objetividade & $\begin{array}{l}\text { citação de autoridades e fontes } \\
\text { objetivas; } \\
\text { technisch, biologisch }\end{array}$ \\
\hline Invoque regras gerais & $\begin{array}{l}\text { afirmações categóricas, por vezes } \\
\text { apoiadas em preceitos morais e } \\
\text { conhecimento type; uso do } \\
\text { pronome man; }\end{array}$ \\
\hline Defocalize os participantes & $\begin{array}{l}\text { Nominalização do resultado de } \\
\text { ações do interlocutor; } \\
\text { falante coloca-se hipoteticamente } \\
\text { no lugar do interlocutor: ich würde } \\
\text { (nicht)...; } \\
\text { falante dirige pergunta a si } \\
\text { mesmo: ich frage mich... }\end{array}$ \\
\hline $\begin{array}{l}\text { Afastamento epistêmico: utilize } \\
\text { verbos modais }\end{array}$ & verbo modal sollen + infinitivo \\
\hline
\end{tabular}




\begin{tabular}{|l|l|}
\hline $\begin{array}{l}\text { ESTRATÉGIA DE COMPENSAÇÃO } \\
\text { NEGATIVA }\end{array}$ & \multicolumn{1}{|c|}{ REALIZAÇÃO LINGÜÍSTICA } \\
\hline $\begin{array}{l}\text { Afastamento temporal: gerencie } \\
\text { a dêixis temporalo }\end{array}$ & $\begin{array}{l}\text { uso do tempo passado do verbo } \\
\text { modal wollen }\end{array}$ \\
\hline Indique relutância & $\begin{array}{l}\text { müssen/können (nur/einfach) }+ \\
\text { verbos dicendi; formulações } \\
\text { explícitas de relutância }\end{array}$ \\
\hline Peça desculpas & fórmulas: Entschuldigung, bitte \\
& um Entschuldigung, entschuldigen \\
& Sie, Verzeihung, verzeihen Sie, \\
& leider \\
\hline
\end{tabular}

\subsubsection{Estratégias off record em Dissensões diretas}

Conforme mencionado no item 3.2.1, estratégias off record também podem ser utilizadas como auxiliares de estratégias diretas. Quando estratégias implícitas são utilizadas sozinhas para realizar a Dissensão, não se pode imputar ao falante a sua intenção de divergir do interlocutor. Quando, por outro lado, a Dissensão já foi explicitada por meio de outros procedimentos, estratégias off record podem ainda ser usadas como ações de compensação. É nossa opinião que estratégias off record assim utilizadas tornam-se um caso extremado de Compensação Negativa, pois que visam a dissociar ainda mais o falante da Dissensão realizada através das outras estratégias.

No corpus da pesquisa, as seguintes estratégias implícitas foram utilizadas como compensação em Dissensões:

\subsection{Dê pistas para associações}

Nesta estratégia, já apresentada no item 3.2.1.1, o falante fornece pistas que levem o interlocutor a uma cadeia de associações, culminando em uma Dissensão. No exemplo a seguir, a falante, após sinalizar a Dissensão com uma pergunta negativa, repete um elemento da fala do interlocutor com entonação alterada. Procurando pela relevância de tal procedimento, o interlocutor deve concluir que o falante discorda desse ponto em especial da sua contribuição: 
[...] (ich mein) ich gebe zu, das ist eine große Ähnlichkeit. aber bringen sie da nicht einiges durcheinander? versteinerte Bouletten? ich mein $+g+$ ich (ALM16)

O mesmo procedimento é encontrado em outros exemplos, como:

A: wir haben sie ja bisher fair behandelt.

$B$ : sie haben mich fair behandelt? sie haben mich verleumdet (Herr

Löwenthal) (GUE3)

\subsection{Use perguntas retóricas}

Assim como no item anterior, a pergunta retórica deixa ao interlocutor a responsabilidade de interpretá-la como uma Dissensão explícita ou como um pedido de esclarecimentos, ao menos pro forma, como nos exemplos a seguir:

(aber jetzt halten sie unsere Zuschauer für dumm) (sie haben doch eben gesagt wir waren mit Herrn Kindler in Bevilaqua) wie können sie denn behaupten wir hätten nichts geprüft? (das geht doch gar nich). (GUE17)

ich möcht etwas sagen zu dem, was Frl. Fleitner sagt. ich glaube, das ist ein typischer Fehler ihrer Erziehung, das sie sagt, ich kalkuliere mit ein, daß ich mal heiraten werde, denn ich meine so kommen wir mit der Emanzipation nie weiter, [...] warum sind wir inzwischen nicht soweit, daß sie sagen + g + ich möchte zunächst einmal meinen Beruf haben [...] warum schränken sie sich sofort wieder ein, indem sie sagen, ich werde doch heiraten? (MAE39)

\subsection{Seja irônico}

Nesta estratégia, já explicada no item 3.2.1.2, o falante indica que sua contribuição não deve ser entendida literalmente, geralmente através da entonação, sendo que ele pretende transmitir exatamente o contrário do que foi dito. Dentre os exemplos presentes no corpus da pesquisa, destacamos o seguinte, no qual o falante utiliza a expressão etwas ('um pouco'), quando quer na realidade dizer $z u$ ('demais') ausschließlich:

man darf auch nicht immer an den Kraftfahrer denken, wie Herr Dr. Seehum aber etwas ausschließlich getan hat (TRA32) 


\subsection{Seja incompleto}

O fato de deixar a Dissensão "em suspenso" transfere ao interlocutor a responsabilidade de completá-la e avaliar o possível grau de ameaça à Face. No único exemplo do corpus, mesmo não completando a sentença (und dann plötzlich...), a falante reforça sua discordância, já sinalizada anteriormente por ein bißchen plötzlich:

(ja) ich meine es ist ich find es $n$ bißchen plötzlich, wenn man also von zu Hause wegrennt und dann plötzlich $+g+$ das ist aber doch gar nicht nötig. (MAE6)

\subsection{Exagere}

Nesta estratégia, o falante utiliza-se de um grau maior na escala de avaliação de um fato do que aquele que corresponderia à realidade. No exemplo a seguir, a falante extrapola o pólo negativo da escala de verossimilhança atribuída à contribuição do interlocutor, qualificando-a como "puro disparate".

[wann die da krabbelten] (nein) vor allem ich mein diese diese Unterstellungen sind typisch männlich. $+g+$ sie denken jetzt Bouletten ißt man lebendig. das ist natürlich reiner Unfug. (ALM32)

\subsection{Use metáforas}

$\mathrm{O}$ uso de metáforas distancia o falante da ameaça à Face simplesmente pelo fato de que não se pode imputar-lhe com certeza qual das conotações da metáfora está sendo colocada em evidência, i.e., as negativas ou as positivas.

(nein) nicht für den Staat (Herr Kollege Mischnick) also bleiben wir hier bei einfach beim Steuer der Wahrheit. in kei:nem angelsächsischen in keiner angelsächsischen Demokratie, die nur das sogennante Mehrheitswahlrecht kennt, kann man sagen, daß es eine Existenzfrage gibt des Staates oder eine Gefahr für den Staat besteht. (COA16) 
Ao sugerir que continuem sendo guiados pelo "leme da verdade", o falante deixa ao interlocutor a possibilidade de entender tal metáfora apenas como uma sugestão neutra, em prol do sucesso da interação, ou como uma crítica às suas contribuições ou ainda, inclusive, como uma imputação de estar deliberadamente desprezando a verdade. Assim, as Faces do interlocutor e também do falante são poupadas.

\subsection{Seja vago}

Utilizando-se de elipses e formulações vagas, deixa-se ao interlocutor a tarefa de decidir se interpreta ou não a contribuição do falante como ameaçadora à sua Face. No exemplo abaixo, ao rejeitar uma sugestão de uma ouvinte sobre um tipo de "toque de recolher", o falante faz a observação isto é sempre o problema, embora sem especificar o que é que ele considera um problema: pessoas que pensam como a ouvinte? o fato de não se poder passear a noite?

das find ich unerträglich, wenn wir nicht mehr $+g+$ wenigstens $n$ bißchen rumlaufen dürfen. das ist immer das Problem (TRA68)

\subsection{A realização lingüística de estratégias off record em Dissensões diretas}

Conforme já apresentado no item 3.2.1.5, referente ao uso de estratégias off record como base para a expressão da Dissensão, tais estratégias baseiam-se em manipulações do Princípio de Relevância baseadas no conhecimento type e token dos participantes, sendo portanto, formuladas em dependência com o contexto comunicativo na qual se inserem. Desse modo, as ocorrências de uso de Estratégias off record como auxiliares de Estratégias Diretas na expressão da Dissensão são apresentadas, juntamente com comentários sobre sua formulação, nas ocorrências constantes do Anexo. 


\section{CAPÍTULO IV - INTERPRETACC̃̃O DOS RESULTADOS}

\subsection{O uso das Estratégias de Trabalho da Face na expressão da Dissensão}

O exame dos resultados apresentados no Capítulo III leva-nos a algumas considerações sobre as relações entre a Dissensão e as Estratégias de Trabalho da Face empregadas para sua expressão.

Conforme já mencionado no item 3.2, a expressão direta da Dissensão, sem qualquer estratégia de compensação, foi, em termos gerais, a forma menos utilizada no corpus da pesquisa. Isto aponta para a conclusão de que a Dissensão é realmente considerada um FTA potencialmente disruptivo para a interação, o que leva os participantes a procurar compensá-la através das demais super-estratégias de Trabalho da Face. O resultado mostra, também, que a propalada "tendência para ser direto" dos alemães pode aparecer no contato com outras culturas que desprivilegiem ainda mais a expressão direta e sem compensação da Dissensão, mas que esta não é a forma única ou mesmo a preferida pelos falantes de alemão.

No entanto, também as Estratégias off record como as únicas utilizadas para expressar a Dissensão apresentaram pequena porcentagem de ocorrência. Tal fato pode ser facilmente entendido à luz do Trabalho da Face: se uma Dissensão é tão importante para o falante, a ponto de que ele se arrisque a prejudicar a interação por sua causa, não lhe é interessante formulá-la de um modo tão impreciso, que o leve a correr o risco de que não seja percebida pelo interlocutor. A quase totalidade dos casos de uso de Estratégias off record (tanto como estratégia básica como auxiliar na expressão da Dissensão) utilizou-se da criação de implicaturas através da manipulação do Princípio de Relevância, sendo que a freqüência de uso das demais Estratégias off record não chega a ser significante, pois que nenhuma ultrapassa $0,6 \%$.

O gráfico apresentado à página 87 mostra um admirável equilíbrio entre as freqüências de uso de Estratégias de Compensação Positiva e Negativa, ilustrando perfeitamente o jogo de aproximação e afastamento do falante, que busca o equilíbrio entre as necessidades de suas Faces e das dos interlocutores. Os resultados obtidos comprovam, ainda, que as estratégias baseadas na polidez positiva, que raramente são consideradas na maioria dos estudos dedicados à "polidez", são tão importantes, em alemão, quanto as estratégias baseadas no afastamento que caracteriza a polidez negativa. 
Contudo, lembramos que Estratégias off record também podem ser utilizadas como estratégias de compensação em Dissensões diretas e que optamos por considerá-las, neste uso, como um caso extremado de Compensação Negativa. Desse modo, a porcentagem de uso de Estratégias de Compensação Negativa, somada à de Estratégias off record auxiliares, ultrapassa ligeiramente a do uso de Compensação Positiva, confirmando a observação de BROWN \& LEVINSON, de que as estratégias baseadas na polidez negativa, ou seja, no distanciamento, são a forma de Trabalho da Face privilegiada na sociedade ocidental.

O gráfico a seguir ilustra a porcentagem de ocorrência das 38 estratégias formais de Trabalho da Face, derivadas das quatro superestratégias (Expressão Direta, sem compensação; Compensação baseada na Polidez Positiva; Compensação baseada na Polidez Negativa e Expressão off record) e utilizadas na expressão da Dissensão no corpus da pesquisa, as quais encontram-se listadas às páginas 90 e 91. Os resultados são comentados no item 4.2 e em seus sub-itens.

É interessante ainda notar, no gráfico, a alternância de Estratégias de Compensação Positiva e Negativa, no que se refere às quatro estratégias formais mais utilizadas: desconsiderando-se as ocorrências de Dissensão direta sem compensação e de uso de Estratégias off record, temos, em primeiro lugar, uma estratégia de Compensação Positiva (dê (ou peça) razões - 16,14\%), seguida de uma estratégia de Compensação Negativa (relativize a própria opinião - 13,75\%), seguida novamente por uma estratégia positiva (crie/pressuponha pontos comuns - 9,65\%) e de outra estratégia negativa (gerencie o grau de realidade - 5\%), o que volta a apontar para o equilíbrio entre as duas formas de Compensação. 
FrEQÜÊNCIA DE OCORRÊNCIA DAS ESTRATÉGIAS FORMAIS DE

TRABALHO DA FACE NO CORPUS DA PESQUISA (\%)

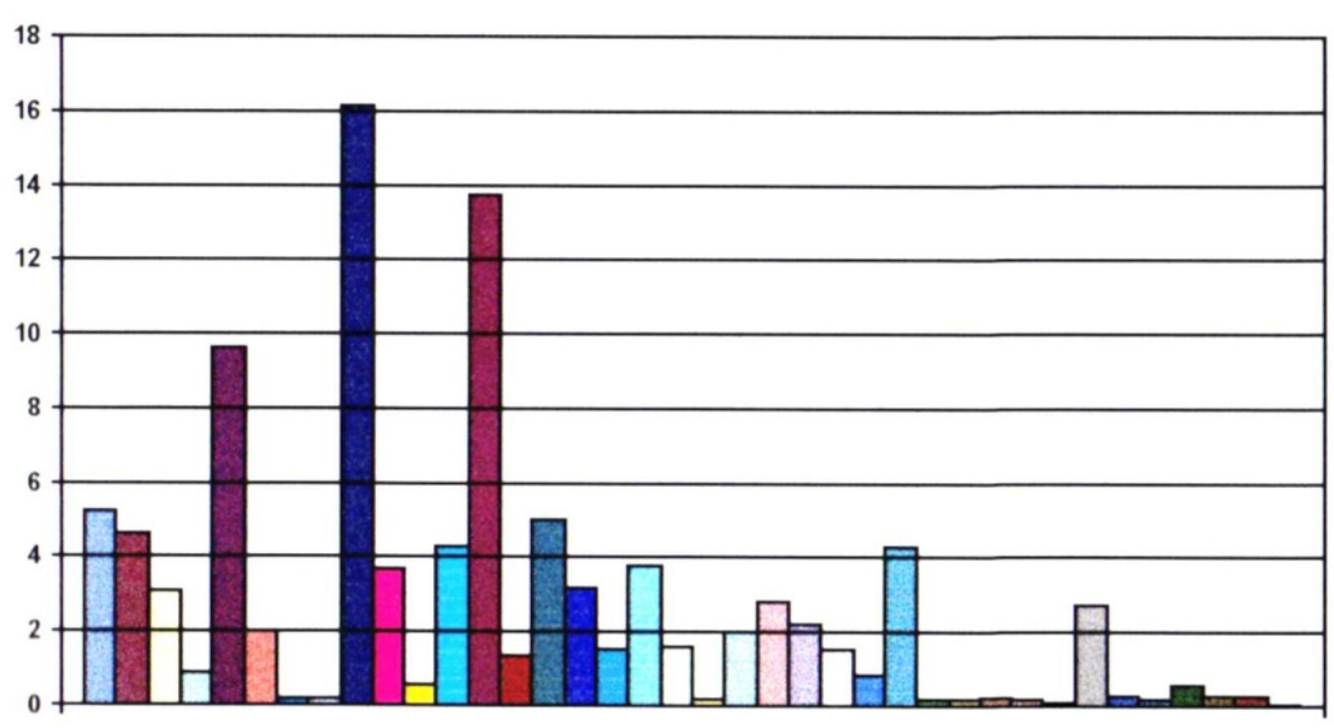

\begin{tabular}{|c|c|c|}
\hline 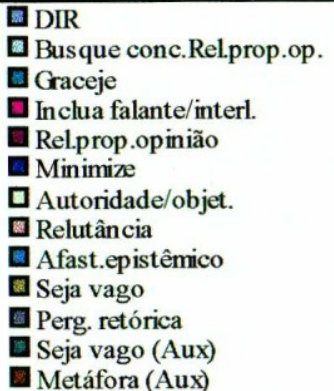 & 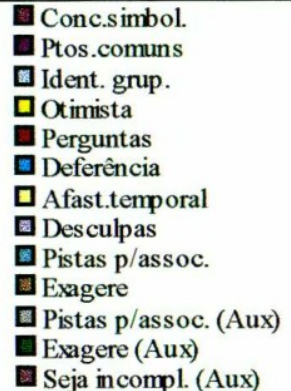 & 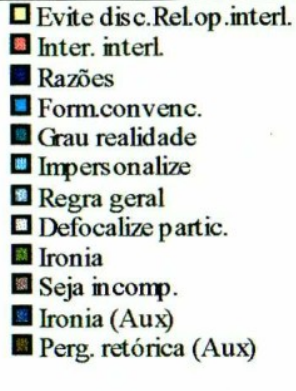 \\
\hline
\end{tabular}

\subsection{As Estratégias de Compensação na expressão da Dissensão}

Considerando-se as estratégias formais elencadas por BROWN \& LEVINSON em seu trabalho, nota-se que nem todas ocorreram no corpus da pesquisa: dentro da Compensação Positiva, não houve casos das estratégias note, atenda ao interlocutor; afirme conhecimento e preocupação com suas necessidades; ofereça, prometa; afirme reciprocidade ou dê-lhe presentes. Quanto à Compensação Negativa, não houve casos de uso das estratégias seja pessimista e expresse-se como incorrendo em débito para com o interlocutor. Isto nos leva a concluir que o oferecimento de 
presentes e demonstrações de preocupação com o bem-estar do interlocutor, bem como estratégias que colocam o falante em clara desvantagem frente ao interlocutor não são consideradas adequadas para a compensação da Dissensão.

Por outro lado, as estratégias que têm por fim criar uma base comum de argumentação entre falante e interlocutor, na Compensação Positiva, ou que buscam minimizar o impacto da Dissensão ou diminuir a responsabilidade do falante, na Compensação Negativa, mostraram-se especialmente privilegiadas. Tal fato fica bem claro ao se examinar as estratégias mais utilizadas para a Compensação Positiva (dê razões e crie/pressuponha pontos comuns) e para a Negativa (relativize a própria opinião), as quais apresentam uma freqüência de ocorrência muito superior à de todas as demais estratégias formais.

\subsubsection{As Estratégias de Compensação Positiva}

Dentre as Estratégias de Compensação Positiva, nota-se a grande predominância da estratégia dê (ou peça) razões, sendo inclusive a estratégia mais usada dentre todas. A alta freqüência de ocorrência pode ser devida ao próprio tipo de interação dos inquéritos: em discussões em meios de comunicação públicos, espera-se que os participantes justifiquem suas opiniões e, por conseguinte, suas Dissensões. No entanto, a justificativa baseada em oferecimento ou solicitação de razões para a discordância não está presente em todas as expressões de Dissensão, e sim, apenas em 16\% das mesmas, o que nos leva a crer que, embora o tipo de interação propicie sua maior freqüência de uso, a justificativa ainda é apenas uma das opções do falante para compensar as Faces frente à ameaça da Dissensão.

Expondo suas razões, o falante leva o interlocutor a participar de seu pensamento, aproximando-os e diminuindo o impacto da Dissensão. O mesmo espírito anima a segunda estratégia de Compensação Positiva mais utilizada, crie/pressuponha pontos comuns $(9,65 \%)$, o que nos leva à conclusão de que a ênfase nos pressupostos sociais e cognitivos partilhados pelo falante e pelo interlocutor (os quais fornecerão uma base comum e os levarão, "quase que conjuntamente", a concluir pela necessidade de uma reavaliação do conteúdo em questão) é a tática preferida para compensar positivamente a Dissensão. 
As três estratégias de Compensação Positiva mais utilizadas a seguir, respectivamente, concorde simbolicamente $(4,65 \%)$, inclua falante e interlocutor na atividade $(3,7 \%)$ e relativize a opinião do interlocutor (3,1\%), perseguem outro objetivo: simular pontos de contato entre as opiniões dos participantes, que dão a impressão de proximidade entre os mesmos, sem, contudo, influênciar o raciocínio apresentado pelo falante para a sua Dissensão. $O$ mesmo vale para a estratégia busque concordância: relativize a própria opinião, que, no entanto, apresentou uma freqüência de uso pouco significativa $(0,9 \%)$.

A outra estratégia de Compensação Positiva que apresenta ocorrência significativa de uso, intensifique o interesse pelo interlocutor (2\%), baseia-se apenas na aproximação pessoal, afetiva, entre os participantes, como sinal de boa vontade, para compensar a realização da Dissensão como elemento desestabilizador da relação. $O$ mesmo procedimento está por trás das demais estratégias utilizadas para a Compensação Positiva e que apresentaram uma freqüência de uso pouco significativa (a saber: seja otimista, graceje, utillize marcadores de identidade grupal, todas abaixo de $0,6 \%$ ).

Partindo destes resultados, podemos concluir que, em situações de discussão entre falantes alemães, as estratégias de Compensação Positiva que enfatizam a base argumentativa comum ou que ressaltam pontos de contato quanto ao raciocínio envolvido na avaliação do conteúdo em questão, ou seja, elementos cognitivos, supostamente objetivos, têm precedência sobre o aspecto afetivo e de relacionamento entre os participantes, quando se trata de compensar Dissensões.

\subsubsection{As Estratégias de Compensação Negativa}

A estratégia relativize a própria opinião $(13,75 \%)$, a mais utilizada para a Compensação Negativa, procura diminuir o impacto da Dissensão sobre o interlocutor, apresentando a opinião do falante como não tão contrária à do interlocutor, ou ainda apenas como uma opinião pessoal. Em ambos os casos, o interlocutor tem a possibilidade de considerar a opinião exposta na Dissensão como apenas uma outra possibilidade, que não invalida (necessariamente ou ao menos pro forma) a sua própria. Dessa maneira, o falante evita invadir a esfera de liberdade de opinião do 
interlocutor. O mesmo raciocínio determina outras estratégias de Compensação Negativa que tiveram menor freqüência de ocorrência, como minimize a imposição $(3,2 \%)$ e faça perguntas $(1,35 \%)$.

A segunda estratégia de Compensação Negativa mais utilizada, gerencie o grau de realidade (5\%), é resultado de outra tática: o falante procura dissociar-se da responsabilidade pela Dissensão, apresentando-a como apenas hipotética e deixando ao interlocutor a possibilidade de desconsiderá-la. O mesmo procedimento de afastar-se (e/ou ao interlocutor) da responsabilidade ou do alvo da Dissensão pauta as estratégias impersonalize $(3,8 \%)$, invoque regras gerais $(2 \%)$, apele à autoridade/objetividade $(1,6 \%)$, defocalize $(1,53 \%)$ e afastamento epistêmico $(0,82 \%)$.

Um terceiro procedimento para a Compensação Negativa é demonstrar explicitamente respeito pela individualidade do interlocutor e compensá-lo através da reafirmação do conhecimento das regras sociais que regem o relacionamento entre os participantes da discussão, demonstrando, assim, que a Dissensão não deve ser entendida como um elemento desestabilizador desse relacionamento. Seguem este procedimento as estratégias utilize formas convencionalizadas $(4,3 \%)$, indique relutância $(2,8 \%)$, peça desculpas $(2,2 \%)$ e dê deferência $(1,55 \%)$.

Examinando tais resultados, podemos concluir que, dentro da Compensação Negativa em situações de Dissensão, há duas grandes táticas de dissociação: primeiramente, o falante procura afastar sua opinião daquela do interlocutor, apresentando-as como duas possibilidades distintas que não necessariamente se anulam; a segunda possibilidade é assumir a Dissensão, mas apresentá-la como se ela não partisse diretamente do falante ou não dissesse respeito diretamente ao interlocutor. Em ambos os casos, o que está em jogo é a relação entre a Dissensão em si (ou seja, opiniões conflitantes) e os participantes da interação.

A terceira possibilidade de Compensação Negativa, por outro lado, centra-se no relacionamento entre os participantes e não na Dissensão. Como na Compensação Positiva, esta linha de ação, "mais afetiva", é a menos utilizada também para a Compensação Negativa de Dissensões em discussões entre falantes alemães. 


\subsection{As Categorias de Dissensão e as Estratégias de Trabalho da Face}

Com relação às categorias de Dissensão definidas no item 2.2.2, as Estratégias de Trabalho da Face distribuíram-se da seguinte maneira no corpus da pesquisa:

\subsubsection{A Dissensão referente à Expressão Lingüística}

Este tipo de Dissensão refere-se à expressão lingüística utilizada pelo interlocutor, a qual o falante considera inadequada. Conforme já discutido no item 2.2.2.1, por vezes esta categoria de Dissensão é utilizada estrategicamente para criticar, de modo indireto, o interlocutor. Assim, subdividimos este item em Dissensão referente à Expressão Lingüística e em Uso Estratégico da Dissensão referente à Expressão Lingüística.

Nas ocorrências de Dissensão referente à Expressão Lingüística, as Estratégias de Trabalho da Face distribuíram-se da seguinte maneira:
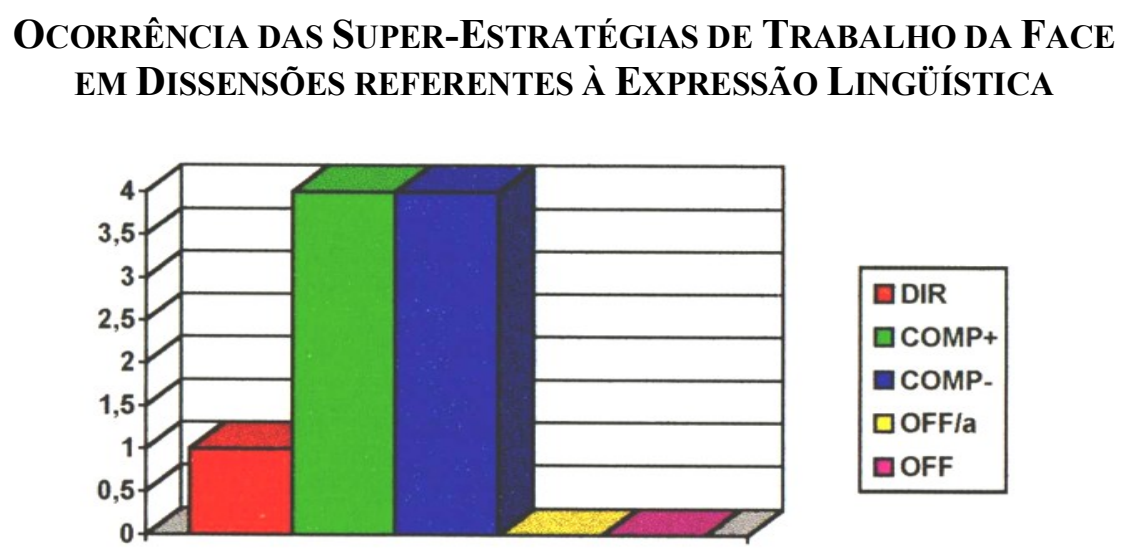

(DIR: Dissenção direta, sem compensação; COMP+: Estratégias de Compensação Positiva; COMP-: Estratégias de Compensação Negativa; OFF/Aux: Estratégias off record utilizadas como auxiliares junto a outras estratégias; OFF: Estratégias off record como responsáveis pela expressão da Dissensão)

Como mostram os gráficos, a Dissensão direta, sem ação de compensação, foi novamente a Estratégia de Trabalho da Face menos utilizada. A inexistência de qualquer ocorrência de Estratégias off record neste item nos leva a concluir que as Dissensões referentes à forma 
língüística são encaradas pelo falante como correções necessárias ao bom desenvolvimento da interação, não podendo correr o risco de passarem desapercebidas. No entanto, a grande maioria das ocorrências desta categoria de Dissensão faz uso de Estratégias de Compensação, ambas exatamente com a mesma freqüência de uso, demonstrando, novamente, a busca do equilíbrio entre a aproximação e o distanciamento entre os participantes.

Embora as super-estratégias de Compensação Positiva e Negativa tenham a mesma freqüência de uso, as estratégias formais utilizadas para realizá-las variam a esse respeito, como mostra o seguinte gráfico:

\section{FREQÜÊNCIA DE OCORRÊNCIA DE ESTRATÉGIAS FORMAIS EM DISSENSÕES REFERENTES À EXPRESSÃo LINGÜÍSTICA}
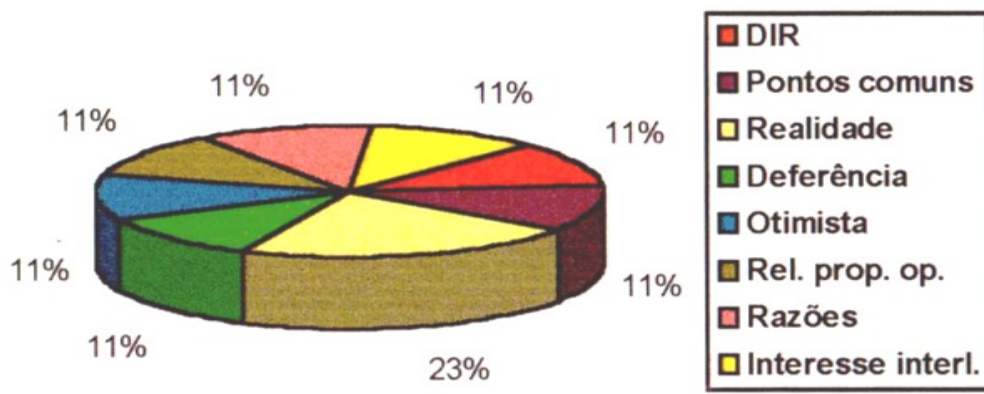

A estratégia formal mais utilizada é gerencie o grau de realidade, (23\%) seguida por outras seis estratégias de compensação e também a expressão direta, sem compensação, todas com a mesma freqüência de uso (11\% cada uma). Partindo de tais resultados, podemos concluir que a estratégia preferida para realizar esta categoria de Dissensão é apresentá-la como apenas hipotética, deixando ao interlocutor a elegante possibilidade de reconhecer seu "erro" e corrigi-lo. As demais possibilidades de compensação englobam tanto estratégias que, no item anterior, foram apresentadas como "mais objetivas", ou seja, centradas na argumentação (como crie/pressuponha pontos em comum, dê (ou peça) razões, relativize a própria opinião) e as estratégias "mais afetivas", centradas no relacionamento entre os participantes (seja otimista, intensifique o interesse pelo interlocutor, dê deferência). 
Nos casos de Uso Estratégico da Dissensão referente à Expressão Lingüística, temos o seguinte quadro:

\section{OCORRÊnCIA daS SuPER-ESTRATÉgIAS dE TrabalHO da FACE NO USO ESTRATÉGICO DE DISSENSÕES REFERENTES À EXPRESSÃO LINGÜÍSTICA}

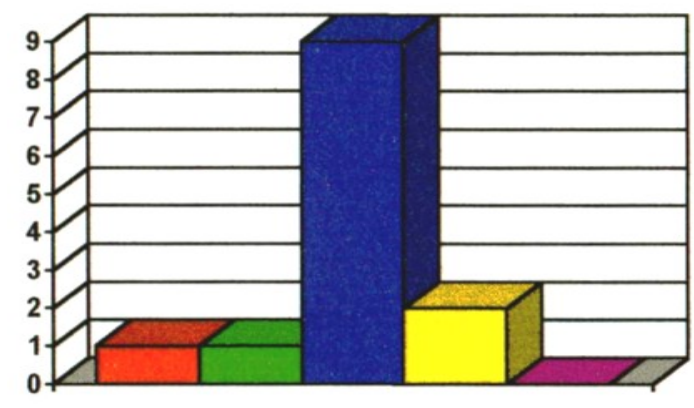

Também neste uso da Dissensão referente à Expressão Lingüística, não há casos de uso exclusivo de Estratégias off record, provavelmente pelas mesmas razões expostas anteriormente a respeito da Dissensão referente à Expressão Lingüística, o que também é válido para os casos de Dissensão direta, sem ação de compensação. No entanto, há um grande predomínio de Estratégias de Compensação Negativa sobre as demais, o que pode ser motivado pelo fato de tal uso (estratégico) desta categoria de Dissensão implicar em críticas ao interlocutor, aumentando a ameaça às Faces e levando o falante a procurar distanciar-se de tal risco. Pode-se também considerar que a freqüência relativamente grande de ocorrência de Estratégias off record como auxiliares em estratégias de compensação (comparada à Dissensão referente à Expressão Lingüística, na qual não houve qualquer ocorrência) é mais um fator favorável a estas reflexões, pois que consideramos tais estratégias como casos extremos de tentativa do falante de afastar-se da Dissensão sem, no entanto, arriscar-se a que ela passe desapercebida. 


\section{FREQÜÊNCIA DE OCORRÊNCIA DE ESTRATÉGIAS FORMAIS \\ No USO ESTRATÉGICO DE DISSENSÕES REFERENTES \\ À EXPRESSÃo LINGÜÍSTICA}

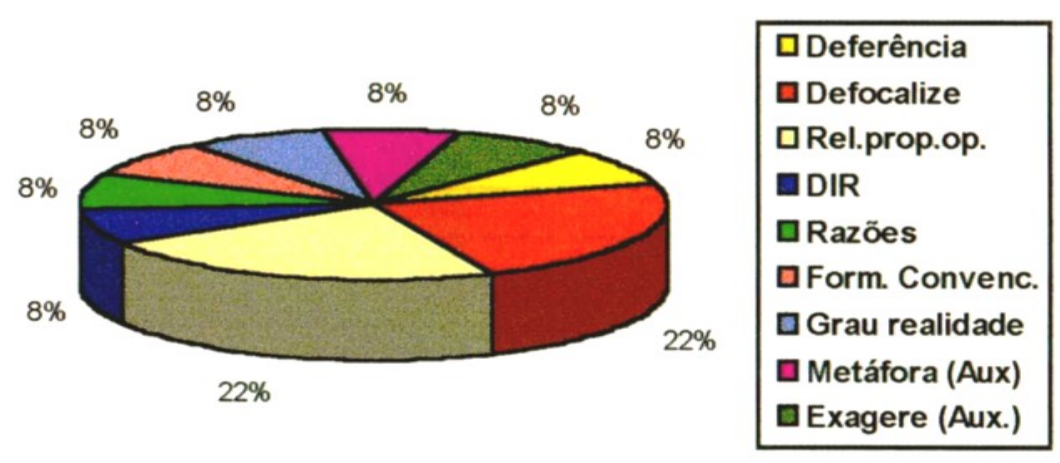

No que se refere às estratégias formais, temos, como mostra o gráfico acima, duas estratégias que se sobressaem, apresentando a mesma freqüência de uso: defocalize os participantes e relativize a própria opinião $(22 \%$ cada). Ambas pertencem às táticas de Compensação Negativa que procuram distanciar o falante e/ou o interlocutor da Dissensão. A estratégia defocalize os participantes é, inclusive, protótipo do uso estratégico da Dissensão referente à Expressão Lingüística, pois que a crítica recai sobre o signo lingüístico quando é, na realidade, endereçada às opiniões e comportamentos de seu produtor.

Em um segundo bloco, estão as demais estratégias formais utilizadas, todas com igual freqüência de uso ( $8 \%$ cada), incluindo a expressão direta, sem compensação. Também aqui encontram-se tanto estratégias "objetivas" (dê (ou peça) razões, gerencie o grau de realidade) quanto "afetivas" (dê deferência, utilize formas convencionalizadas), bem como duas Estratégias off record auxiliares (utilize metáforas, exagere).

\subsubsection{A Dissensão referente a Parte de uma Proposição}

A Dissensão pode também referir-se a apenas parte de uma proposição, sem contestar seu valor de verdade. No corpus da pesquisa, as ocorrências desta categoria de Dissensão foram expressas com as seguintes Estratégias de Trabalho da Face: 
OCORRÊNCIA DAS SUPER-ESTRATÉGIAS DE

TRABALHO DA FACE EM DISSENSÕES REFERENTES

a PARTe de uMa Proposição

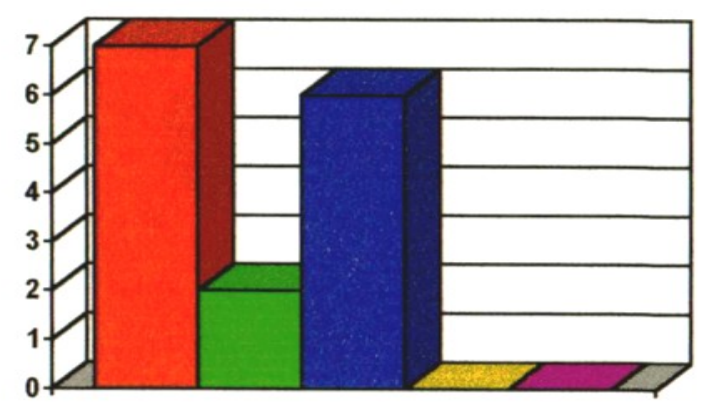

口DIR

口COMP+

口COMP.

DOFFla

口OFF

É interessante notar a alta incidência da expressão direta da Dissensão, sem qualquer estratégia de compensação (o que contraria a tendência geral, apresentada no item 4.1) e a não utilização de Estratégias off record, o que aponta para o fato de que Dissensões referentes a partes da proposição devam ser claramente sinalizadas. Podemos supor que este tipo de Dissensão não é sentido como muito ameaçador para as Faces (provavelmente porque o falante na realidade não invalida a contribuição do interlocutor, mas apenas a "melhora" em determinados pontos) e que Dissensões referentes a partes de uma proposição são encaradas como correções necessárias, das quais o falante está absolutamente seguro, e que ele espera que sejam entendidas como amigáveis pelo interlocutor. No entranto, a freqüência de uso de Estratégias de Compensação Negativa aproxima-se muito à de Dissensões diretas sem compensação, o que nos leva a crer que, ainda assim, muitas vezes, o falante entende que é mais seguro demonstrar sua consciência de que está desrespeitando a Face negativa do interlocutor, ao "invadir seu domínio" e corrigir suas contribuições, e procura compensá-lo, deixando claro que esta não é sua intenção primordial. 
FREQÜÊNCIA DE OCORRÊNCIA DE ESTRATÉGIAS FORMAIS EM DISSENSÕES

Referentes A PARTe de uMa Proposição

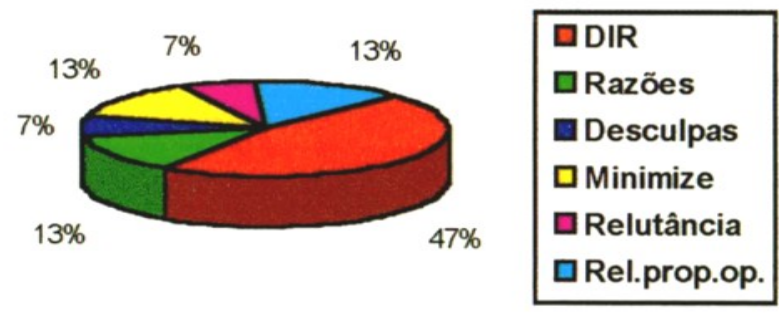

Como mostra o gráfico, as estratégias de compensação utilizadas restringem-se a uma estratégia positiva e quatro negativas: a estratégia de Compensação Positiva dê (ou peça) razões e as Estratégias de Compensação Negativa relativize a própria opinião e minimize a imposição apresentam a mesma freqüência de uso (13\% cada), seguidas das estratégias negativas indique relutância e peça desculpas ( $7 \%$ cada). O falante, assim, demonstra seu respeito ao interlocutor, seja expondo os fatores que o levaram à Dissensão ou sinalizando que a imposição é mínima, reconhecida e não desejada, porém necessária ao bom andamento da interação. Novamente, as estratégias de compensação mais utilizadas são as que se referem à Dissensão em si ou aos argumentos que a justificam, sendo que as estratégias centradas no relacionamento, embora presentes, têm menor freqüência de ocorrência.

Esta categoria de Dissensão poderia ser considerada um equivalente da negação de constituintes (cf. Polenz, 1985: 262) normalmente conhecida em alemão como sondern-Negation, (DUDEN, 1984: 641s.). No entanto, a forma com sondern não foi a mais utilizada no que se refere à expressão lingüística das Dissensões diretas sem ação de compensação, que são maioria nesta categoria de Dissensão: as duas formas lingüísticas mais utilizadas foram, respectivamente, nein, precedendo a informação considerada correta, e (aber) nicht, precedendo a informação considerada inadequada, a qual é corrigida posteriormente. 


\subsubsection{A Dissensão referente à Totalidade da Proposição}

Ao contrário do item anterior, esta categoria segue o padrão geral da distribuição de uso das super-estratégias na expressão da Dissensão, sendo que a expressão direta, sem ação de compensação, é a menos utilizada, seguida de perto pelo uso exclusivo de Estratégias off record, segundo se pode ver nos gráficos a seguir:

OCORRÊNCIA DAS SUPER-ESTRATÉGIAS DE

TrABALHO DA FACE EM DISSENSÕES REFERENTES

À Totalidade de uMa Proposição

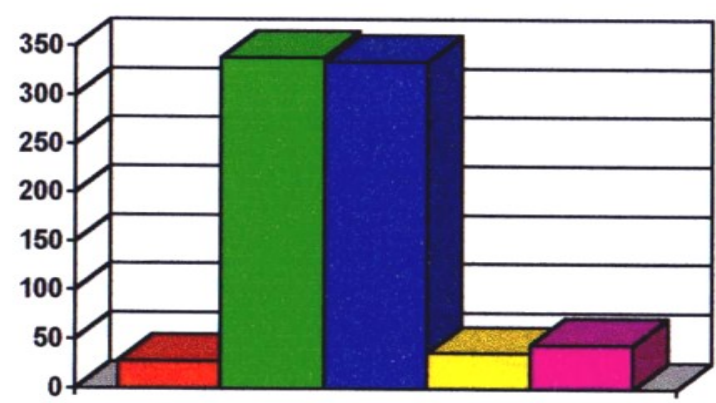

口DIR

口COMP+

口COMP.

DOFFla

DOFF

A Dissensão referente à Totalidade da Proposição, sendo a maioria absoluta das ocorrências de Dissensão no corpus da pesquisa, provavelmente determinou o padrão geral de distribuição das superestratégias, apresentado nos itens 3.1 e 4.1. A Dissensão direta sem ação de compensação é a estratégia menos utilizada (3,58\%), seguida de perto pelas Estratégias off record como estratégias auxiliares $(4,6 \%)$ e como estratégias únicas (5,76\%) para a expressão da Dissensão. As estratégias de Compensação Positiva e Negativa apresentam praticamente a mesma freqüência de uso, com ligeira predominância da primeira (respectivamente, $43,27 \%$ e $42,76 \%$ ). 
FREQÜÊNCIA DE OCORRÊNCIA DE ESTRATÉGIAS FORMAIS EM DISSENSÕES

REFERENTES À Totalidade de UMA ProposiçÃo
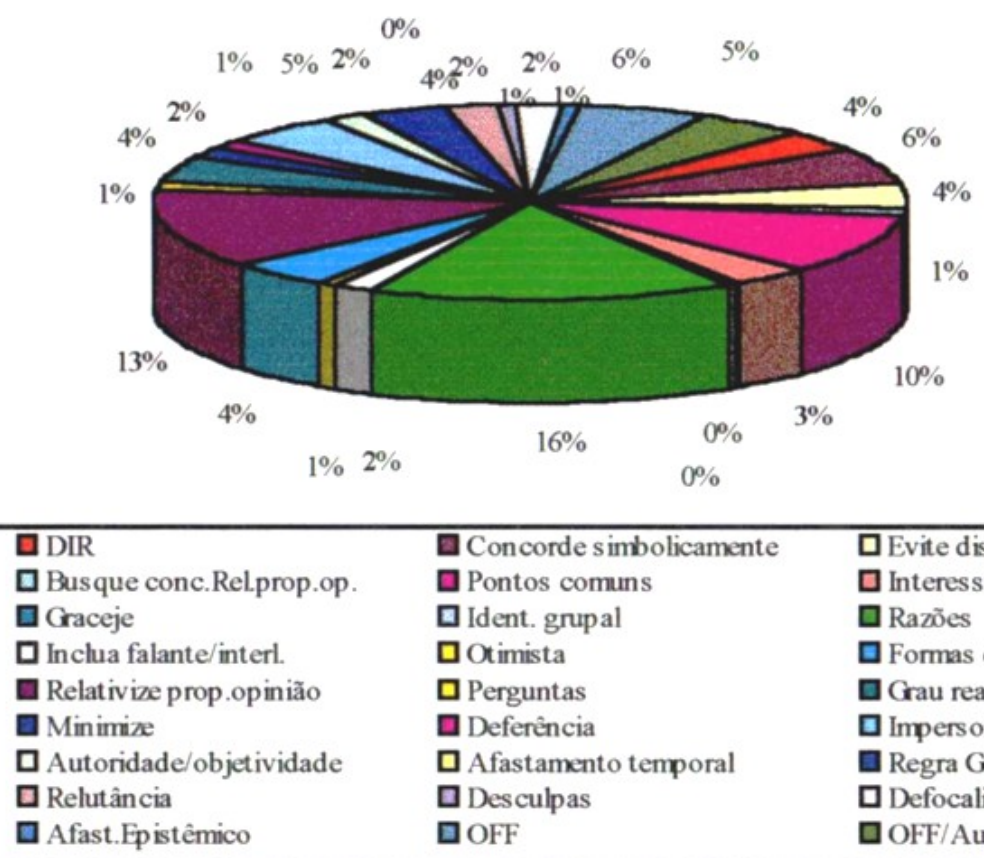

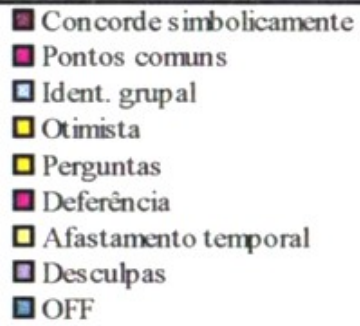

口Evite disc.Relop.int Interesse interlocutor 口 Razões 口 Formas convenc.

口Grau realidade IImpersonalize 口 Regra Geral $\square$ Defocalize participante 口OFF/Aux

As Estratégias de Compensação Positiva mais utilizadas foram principalmente dê (ou peça) razões (16\%), crie/pressuponha pontos em comum (10\%) e concorde simbolicamente (6\%). Na Compensação Negativa, destacam-se as estratégias relativize a própria opinião $(13 \%)$ e impersonalize: gerencie a dêixis pessoal (5\%), esta seguida de perto pelo uso de formas convencionalizadas (4\%). Novamente, as estratégias formais centradas na argumentação e na relação entre a Dissensão e os participantes foram as mais utilizadas, frente as estratégias que privilegiam o relacionamento entre os participantes da discussão.

Dentre as Estratégias off record responsáveis pela expressão da Dissensão, a estratégia dê pistas para associações foi a mais utilizada, tanto como estratégia única (4\%) como auxiliar (2\%) na expressão da Dissensão. 


\subsubsection{A Dissensão referente ao Rumo da Interação}

Nesta categoria de Dissensão, o falante procura bloquear o rumo que o interlocutor está imprimindo à interação, atuando, assim, em um nível extra-proposicional. Tais ocorrências de Dissensão foram expressas, no corpus, com o auxílio das seguintes Estratégias de Trabalho da Face:

\section{Trabalho da FaCE EM DisSensões ReFERENTES AO RUMO DA INTERAÇÃO}
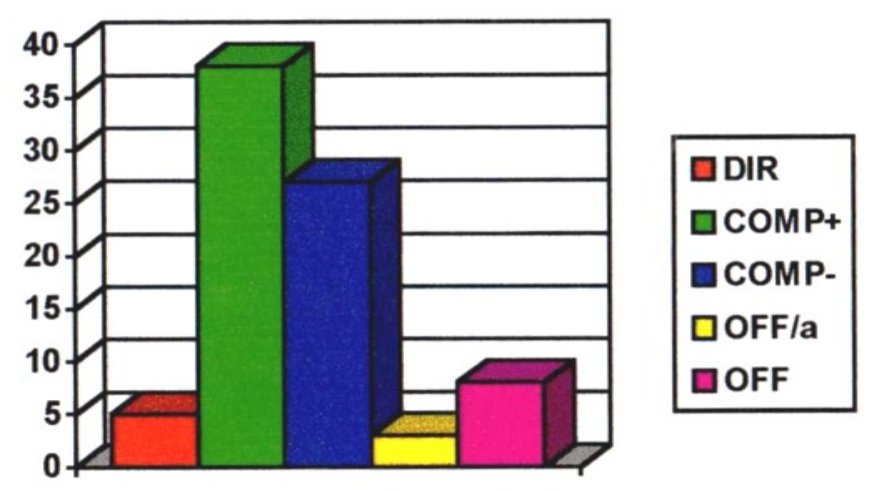

Nesta categoria de Dissensão, estão representadas todas as superestratégias de Trabalho da Face, sendo que as Estratégias de Compensação Positiva superam todas as demais por uma margem considerável, como se pode ver no gráfico acima. Tal fato nos leva a ponderar que, para se mudar o rumo da interação sem, no entanto, rompê-la, é considerado mais prudente apresentar a Dissensão enfatizando os pressupostos de igualdade e colaboração entre os participantes. Ao contrário da Dissensão referente a Parte da Proposição, na qual a Dissensão direta, sem compensação, era largamente utilizada, dando a entender que tal Dissensão era menos ameaçadora para as Faces, a Dissensão referente ao Rumo da Interação é largamente compensada, positiva e negativamente, sendo que mesmo as Estratégias off record são mais utilizadas que a expressão sem compensação. $O$ falante parece preferir arriscar que sua Dissensão não seja contemplada pelo interlocutor a apresentá-la diretamente e, assim, sofrer possíveis conseqüências negativas de tal quebra das regras sociais. Talvez isto se dê pelo fato de que a interação comunicativa só seja possível através da participação de todos os interlocutores de acordo com regras respeitadas 
mutuamente, e a violação de tais regras só é considerada viável como resultante de um novo acordo tácito entre os participantes (exceto nos casos nos quais a assimetria social é tão grande ou as relações entre os participantes tão deterioradas, que as Faces não precisem mais ser respeitadas). As estratégias formais utilizadas para esta categoria de Dissensão corroboram esta hipótese, como mostra o gráfico a seguir:

\section{FREQÜÊNCIA DE OCORRÊNCIA DE ESTRATÉGIAS FORMAIS EM DISSENSÕES} REFERENTES AO RUMO DA INTERAÇÃO

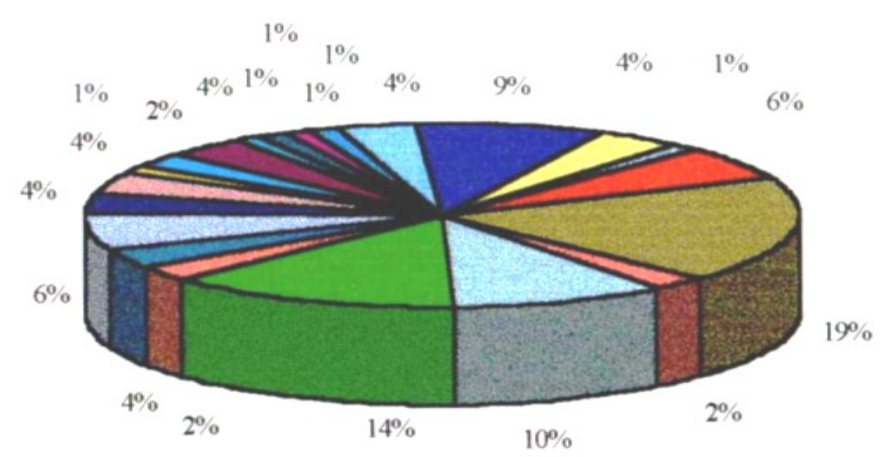

\begin{tabular}{|c|c|c|c|}
\hline 口DIR & 口Razões & DConc.simbol. & 口Pontos comuns \\
\hline 口 Inclua falante/ouv. & 口Otimista & D Formas conv. & 口 Relprop.opinião \\
\hline Degras gerais & 口 Deferência & 口 Objetividade/autor. & 口 Realidade \\
\hline D Afast.temporal & 口 Defocalize part. & 口 Relutância & 口Desculpas \\
\hline $\begin{array}{l}\text { 口 Impersonalize } \\
\text { Seja irônico (Aux) }\end{array}$ & 口Minimize & Distas p/assoc. & 口 Pistas p/assoc.(Aux) \\
\hline
\end{tabular}

A estratégia formal mais utilizada é dê (ou peça) razões (19\%), seguida por inclua falante $\mathbf{e}$ interlocutor na atividade: gerencie a dêixis pessoal $(14 \%)$, a qual estende aos demais participantes a vontade ou as opiniões do falante, simulando uma concordância tácita, assim como a terceira estratégia mais utilizada, crie/pressuponha pontos comuns $(10 \%)$, todas estratégias de Compensação Positiva que acentuam ou buscam a concordância entre os participantes no que se refere à argumentação ou ao rumo da interação.

A estratégia de Compensação Negativa relativize a própria opinião (6\%) foi a mais utilizada, seguida pelas estratégias dê deferência, invoque regras gerais, utilize formas convencionalizadas, minimize a imposição e afastamento temporal, as quais apresentaram igual freqüência de ocorrência ( $4 \%$ cada uma). Novamente, predominam as estratégias centradas na relação entre os participantes e a Dissensão. 
No que se refere à relação entre as diversas categorias de Dissensão e as Estratégias de Trabalho da Face, pudemos notar que as primeiras influenciam tanto a escolha das super-estratégias de Trabalho da Face utilizadas para a expressão da Dissensão como as estratégias formais selecionadas para realizá-las. No entanto, em todas as categorias de Dissensão, nota-se uma predominância, nas Estratégias de Compensação Positiva e Negativa, do uso de estratégias centradas na argumentação e na relação entre os participantes da discussão e a Dissensão, frente a estratégias baseadas no relacionamento entre os participantes. 


\section{CAPÍTULO V - CONSIDERACCÕES FINAIS}

A partir de observações próprias e de trabalhos científicos sobre o tema, interessamo-nos pela expressão de Dissensões por parte de falantes alemães no que se refere aos procedimentos utilizados para manter o bom andamento de uma interação lingüística, que denominamos Trabalho da Face, com base nos estudos de Goffman. Para tanto, decidimo-nos por um estudo empírico que teve como objetivos a realização de um levantamento de formas lingüísticas e a definição de estratégias de Trabalho da Face utilizadas na expressão da Dissensão, bem como de uma proposta de sistematização da utilização destas últimas.

Após a revisão da literatura sobre o tema, definimos Dissensão como uma atitude proposicional de desacordo por parte do falante, referente a conteúdos ou atitudes imputados por ele ao seu interlocutor. Um elenco de Estratégias de Trabalho da Face foi definido com base nas quatro super-estratégias propostas por BROWN \& LEVINSON, a saber: expressão direta sem compensação, compensação baseadas na polidez positiva, compensação baseada na polidez negativa e expressão off record, contemplando as adaptações necessárias ao nosso objeto de estudo.

Uma seleção de discussões da mídia eletrônica alemã serviu de base para a constituição do corpus da pesquisa, formado pelas ocorrências de Dissensão constantes dos referidos inquéritos.

A análise de nosso corpus levou-nos a uma categorização das Dissensões, quanto ao seu objeto, em quatro categorias: a Dissensão referente à Expressão Lingüística utilizada pelo interlocutor, que por sua vez, apresenta um uso especial, que denominamos Uso Estratégico da Dissensão referente à Expressão Lingüística, a Dissensão referente a Parte da Proposição, a Dissensão referente à Totalidade da Proposição e a Dissensão referente ao Rumo da Interação, sendo que tais categorias provaram-se influentes quanto à seleção das Estratégias de Trabalho da Face utilizadas em situações de Dissensão.

Os resultados obtidos nos permitem concluir que aquilo que coloquialmente se entende por "discordância" e que aqui denominamos Dissensão tem sua forma prototípica na Dissensão referente à Totalidade da Proposição, categoria à qual pertence a imensa maioria das ocorrências do corpus. A categoria Dissensão referente ao Rumo da Interação é a 
segunda mais utilizada, pois, como já mencionamos no início do Capítulo III, o falante pode optar por interromper o rumo que o interlocutor vem imprimindo à interação, além do fato de que os moderadores estão autorizados, pelas regras do tipo de interação "Discussão", a redirecioná-la e retirar dos participantes o uso da palavra.

\section{A Dissensão referente à Expressão Lingüística e Dissensão} referente a Parte da Proposição têm uma freqüência de ocorrência bastante reduzida, pois normalmente os participantes de Discussões na mídia estão preparados com os elementos necessários para discorrer sobre os assuntos em pauta, o que diminui a probabilidade de enganos quanto à forma de expressão e a elementos das proposições apresentadas.

Quanto ao Trabalho da Face, as quatro super-estratégias desenvolvidas por BROWN \& LEVINSON foram detalhadas em diversas estratégias formais, resultando em um elenco de 38 possibilidades, resultante da análise do corpus da pesquisa. Para evitar as conotações evocadas pelo uso coloquial do termo "polidez", preferimos o termo "compensação positiva ou negativa", para designar as Estratégias de Trabalho da Face baseadas, respectivamente, na polidez positiva e negativa, conforme descritas por BROWN \& LEVINSON.

Tanto no que se refere às super-estratégias quanto às estratégias formais, percebe-se que as Estratégias de Trabalho da Face orientam-se com relação aos conceitos de respeito às Faces positiva e negativa dos participantes da interação. Desse modo, nota-se que existe uma gama de possibilidades organizada em uma escala entre os pólos de "identificação" (polidez positiva) e "afastamento" (polidez negativa) do falante frente ao interlocutor, o que, com relação à Dissensão, parte da busca da afirmação de afinidade entre falante e interlocutor, com o uso de recursos para a aproximação entre ambos e passando paulatinamente ao afastamento, por parte do falante, frente ao interlocutor e/ou à Dissensão, até a sua completa dissociação desta última, através do uso das estratégias off record. Assim, este movimento de aproximação e afastamento pode ser ilustrado pelo seguinte esquema: 


\begin{tabular}{|c|c|c|c|}
\hline APROXIMAÇÃO & & \multicolumn{2}{|c|}{ AFASTAMENTO } \\
\hline $\begin{array}{l}\text { expressão direta } \\
\text { sem compensação }\end{array}$ & $\begin{array}{l}\text { polidez } \\
\text { positiva }\end{array}$ & $\begin{array}{l}\text { polidez } \\
\text { negativa }\end{array}$ & $\begin{array}{l}\text { estratégias } \\
\text { implícitas }\end{array}$ \\
\hline $\begin{array}{c}\text { identificação: } \\
\text { falante/interlocutor }\end{array}$ & \multicolumn{2}{|c|}{$\begin{array}{c}\text { dissociação: } \\
\text { falante/interlocutor }\end{array}$} & $\begin{array}{c}\text { dissociação: } \\
\text { participantes/FTA }\end{array}$ \\
\hline
\end{tabular}

É necessário frisar que esta escala é realmente um contínuo, sendo que as estratégias formais, mesmo dentro das quatro super-estratégias, estarão sempre mais próximas de um ou de outro pólo.

A expressão Direta sem Ação de Compensação foi a super-estratégia menos utilizada no corpus da pesquisa, corroborando a hipótese de que a Dissensão é potencialmente danosa para a interação e que, portanto, deve ser compensada com respeito às Faces.

A segunda super-estratégia menos utilizada foi a expressão off record, de onde concluímos que, apesar de perigosa, os falantes preferem não se arriscar a que a Dissensão passe desapercebida pelo interlocutor devido à uma formulação por demais imprecisa.

As super-estratégias de Compensação Positiva e Negativa apresentaram um admirável equilíbrio quanto à sua utilização no âmbito geral do corpus, ilustrando o Trabalho da Face necessário para manter a distância ótima para o relacionamento entre os participantes da interação, satisfazendo a ambas as Faces dos mesmos.

Entretanto, se considerarmos o uso de estratégias off record como casos extremados de Compensação Negativa, teremos uma pequena superioridade desta super-estratégia em relação à Compensação Positiva, o que se coaduna com a idéia de que, nas sociedades ocidentais, a tática do distanciamento é a forma preferida de compensação às Faces.

A categoria de Dissensão na qual se enquadram as diversas ocorrências tem, contudo, influência sobre a freqüência de uso das superestratégias de Trabalho da Face: enquanto as categorias Dissensão referente à Expressão Lingüística, Dissensão referente à Totalidade da Proposição e Dissensão referente ao Rumo da Interação seguem as proporções indicadas, a categoria Uso Estratégico da Dissensão referente à Expressão Lingüística apresenta imensa predominância da Compensação Negativa, enquanto a Compensação Positiva cai ao nível da expressão Direta sem Compensação e a Dissensão referente a Parte da 
Proposição apresenta predomínio da expressão Direta sem Compensação em detrimento do uso de estratégias de Compensação Positiva. Tais resultados levam à conclusão que, em caso de necessidade de escolha, os falantes podem optar por sacrificar a Compensação Positiva, o que novamente reforça a tese da Compensação Negativa como forma preferida de Trabalho da Face no alemão.

No tocante às diversas estratégias formais consideradas isoladamente, contudo, a mais utilizada foi a estratégia de Compensação Positiva dê (ou peça) razões, provavelmente devido ao tipo de interação (discussão), que propicia estratégias baseadas na argumentação. A segunda estratégia mais utilizada foi a estratégia de Compensação Negativa relativize a própria opinião, enquanto o terceiro lugar é ocupado novamente por uma estratégia de Compensação Positiva, crie/pressuponha pontos em comum. Estas três estratégias apresentam uma freqüência de ocorrência bastante superior a todas as demais (sempre superior a 9\%) . Nota-se, em seguida, a formação de um bloco intermediário no que se refere à sua freqüência de ocorrência (13 estratégias, entre 5 e $2 \%$ ), no qual se encontram a expressão Direta sem Compensação e as estratégias off record e, finalmente, um grupo de estratégias que, embora presentes no corpus, apresentam uma freqüência de uso muito pouco significante (22 estratégias, com freqüência inferior a $2 \%$ cada).

Uma análise das estratégias de compensação mais utilizadas mostra uma preferência pelo uso de estratégias centradas na relação entre os participantes da interação e a Dissensão em si (seja aproximando os participantes no que se refere a seus pressupostos e ao raciocínio que a motivou, seja afastando o falante e/ou o interlocutor da Dissensão a ser expressa), em detrimento de estratégias de compensação centradas no relacionamento entre os participantes da interação. Embora nossa pesquisa não tenha por objetivo uma análise cultural do uso de tais estratégias, gostaríamos de indicar a possibilidade de que esta preferência por estratégias de compensação mais "objetivas" poderia ser uma das causas da avaliação dos falantes alemães como "excessivamente diretos e objetivos" por outras culturas.

Quanto à expressão lingüística da Dissensão, podemos afirmar que não há uma forma lingüística específica para realizá-la. Sendo uma atitude proposicional de desacordo frente ao interlocutor, a forma básica de expressá-la é apresentar uma contribuição que apresente uma proposição contrária ou incompatível com aquela que o falante imputa ao interlocutor. 
Entendemos "proposição contrária" como aquela que apresenta uma atribuição de valores referentes a determinadas propriedades mais próxima, dentro de uma escala contínua entre pólos opostos, do pólo mais afastado da escala com relação ao ponto atribuído pelo interlocutor em sua contribuição. A apresentação da opinião contrária, que representa a expressão da Dissensão por parte do falante, pode acontecer unicamente por meio da criação de implicaturas, através da manipulação do Princípio de Relevância (expressão por meio de estratégias off record), ou ser expressa diretamente através de elementos lexicais que se opõem semanticamente à avaliação do interlocutor sobre determinado conteúdo. Neste caso, quando a avaliação do interlocutor é apresentada ou imaginada positivamente, o falante pode utilizar-se de elementos semanticamente negativos, os quais configuram o protótipo da expressão da Dissensão. Tais elementos, conforme ocorreram no corpus da pesquisa, estão listados no quadro sinótico constante do item 3.2.2.2.

Como apontamos acima, a grande maioria das Dissensões expressas diretamente apresenta procedimentos de compensação através de estratégias de Compensação Positiva ou Negativa. Os procedimentos e elementos lingüísticos utilizados para sua realização no corpus da pesquisa encontram-se, respectivamente, nos quadros sinóticos constantes dos itens 3.2.2.4.10 e 3.2.2.5.12. Alguns expedientes lingüísticos podem ser utilizados tanto para realizar estratégias de compensação baseadas na polidez positiva quanto na polidez negativa, apenas através da variação do posicionamento dentro da escala de aproximação/ afastamento. $\mathrm{Na}$ análise do corpus da pesquisa, identificamos os seguintes casos:

1) gerenciamento da dêixis temporal: o uso do tempo presente em oposição ao passado cria, repectivamente, efeitos de aproximação/subjetividade e afastamento/objetividade, enquanto o uso do modo subjuntivo em oposição ao indicativo manipula o grau de realidade atribuído à Dissensão e cria um efeito de afastamento;

2) gerenciamento da dêixis pessoal: o uso da primeira pessoa do plural pela primeira ou pela segunda do singular cria um efeito de aproximação/subjetividade, enquanto o uso de man, da voz passiva e de formulações assemelhadas a regras gerais cria efeitos de distanciamento/objetividade; 
3) gerenciamento das relações epistêmicas e deônticas: efeitos de aproximação/afastamento são criados através do uso de partículas e verbos modais;

4) negociação do grau de certeza e responsabilidade: uso de hedges, atenuadores e expressões de opinião pessoal relativizam as opiniões apresentadas, aproximando ou afastando falante e interlocutor.

Consideramos ter atendido aos objetivos propostos no início deste trabalho. Gostaríamos, contudo, de frisar que este estudo representa apenas um primeiro recorte de determinados aspectos do Trabalho da Face realizado quando da expressão de Dissensões. Analisamos aqui apenas as estratégias utilizadas pelo falante para compensar as Faces positiva e negativa de seu interlocutor. Conforme salienta KOHNEN em seu estudo, realmente é necessário contemplar as quatro Faces que estão em jogo durante uma interação: as Faces positiva e negativa do interlocutor e as Faces positiva e negativa do falante. Este último também sente a necessidade de proteger as suas Faces frente ao interlocutor, o que desencadeia o uso de outras Estratégias de Trabalho da Face que não foram contempladas neste estudo, como, por exemplo, o uso de intensificadores para dar mais peso à própria opinião (cf. HOUSE/KASPER, 1981). O campo do estudo do Trabalho da Face é muito amplo e ainda pouco explorado. Futuros estudos nessa área provavelmente trarão importantes subsídios para um melhor entendimento do uso da linguagem e de seus efeitos em interações intra- e interculturais. 


\section{REFERÊNCIAS BIBLIOGRÁFICAS}

APELTAUER, Ernst: - "Nichtakkordierende Sprechhandlungen (NASH)". In:

KÜHLweIn, W. \& RAASch, A. (Org.): Sprache und Verstehen - Band 1, Tübingen, Gunther Narr, 1980, p. 69-78.

Aurélio - Novo Dicionário da Língua Portuguesa. $2^{\mathrm{a}}$ ed. Rio de Janeiro, Nova Fronteira, 1986.

BARROS, Diana L.P. - "Procedimentos de reformulação: a correção". In: Análise de textos orais - Projeto NURC/SP. São Paulo, FFLCH/USP, 1993, p.129-156.

BISLE-MÜlLER, Hansjörg - Artikelwörter im Deutschen. Semantische und pragmatische Aspekte ihrer Verwendung. Niemeyer, Tübingen, 1991. BLAKEMORE, Diane - "Denial and contrast: a relevance theoretic analysis of but". In: Linguistics and Philosophy. Vol. 12, Dordrecht/Boston/ London, Kluver, 1989, p. 15-37.

BLÜHDORN, Hardarik - "Sprache und Konflikt: Einige zeichentheoretische Überlegungen zum Status rhetorischer Strategien in der politischen Kommunikation". In: REIHER, Ruth (Org.) - Sprache im Konflikt. Berlin/New York, de Gruyter, 1995, p. 93-112.

Blum-Kulka, S. "Indirectness and Politeness". In: Journal of Pragmatics 11, 1987, p. 131-146.

BRown, Penelope \& LEVInson, Stephen - "Universals in Language Usage: Politeness Phenomena". In: Goody, Esther N. (Org.): Questions and Politeness - Strategies in Social Interaction. Cambridge, Cambridge University Press, 1978, p. 56-324.

BYRNES, Heydi - "Interactional Style in German and American Conversations". In: Text 6 (2). Amsterdam, de Gruyter, 1986, p.189206.

Castilho, Ataliba T. \& CAstilho, Célia M.M. - "Advérbios modalizadores". In: IlARI, Rodolfo (Org.) - Gramática do Português Falado. Vol. II - Níveis de análise lingüística. $3^{\mathrm{a}}$ ed. Campinas, Ed. da UNICAMP, 1996, p. 213-260.

COULMAS, Florian - "On the sociolinguistic relevance of routine formulae". In: Journal of Pragmatics 3, 1979, p. 239-266.

(Org.) - Conversational Routine. The Hague/Paris/ New York, Mouton, 1981.

DAVIDSON, Alice: - "Indirect Speech Acts and what to do with them". In Cole, Peter \& Morgan, Jerry (Org.): Syntax and Semantics - Vol. 3 - Speech Acts. New York, Academic Press, 1975, p. 143-185.

DuboIS, Jean et. al. Dicionário de Lingüística. Tradução de Izidoro Blickstein (Org.). São Paulo, Cultrix, 1997. 
DUDEN - Deutsches Universalwörterbuch. Drodowski, Günther (Org.). Mannheim/Wien/Zürich, Bibliographisches Institut, 1983.

DUDEN - Grammatik der deutschen Gegenwartssprache. Drodowski, Günther (Org.). Mannheim/Wien/Zürich, Bibliographisches Institut, 1984.

EnGEL, Ulrich - Deutsche Grammatik. Heidelberg, Julius Groos, 1988.

FIORIN, José Luiz - As Astúcias da Enunciação. São Paulo, Ática, 1996.

FRASER, Bruce - "Conversational Mitigation". In: Journal of Pragmatics 4, 1980, p. 341-350.

GENZMER, Herbert A.K. - Mendacity: on contrastive discourse structures in German, English and Spanish. Michigan, University Microfilms International, 1987.

GOFFMAN, Erving - Interaktionsrituale: Über Verhalten in direkter Kommunikation. Frankfurt a.M., Suhrkamp, 1986 (original americano de 1967).

Grice, H. Paul - "Logic and Conversation". In: Cole, Peter \& Morgan, Jerry (Org.): Syntax and Semantics. Vol. 3 - Speech Acts. New York, Academic Press, 1975, p. 41-58.

GÜNTHNER, Susanne - Diskursstrategien in der interkulturellen Kommunikation - Analysen deutsch-chinesischer Gespräche. Tübingen, Niemeyer, 1993.

Helbig, Gerhard - Lexikon deutscher Partikeln. $2^{\mathrm{a}}$ ed. Leipzig, Verlag Enzyklopädie, 1990.

HELD, Gudrun - Verbale Höflichkeit - Studien zur linguistischen Theoriebildung und empirische Untersuchung zum Sprachverhalten französischer und italienischer Jugendlicher in Bitt- und Dankessituationen. Tübingen, Gunter Narr, 1995.

HERINGER, Hans Jürgen - Lesen Lehren Lernen - Eine rezeptive Grammatik des Deutschen. Tübingen, Niemeyer, 1989.

Hindelang, Götz - "Argumentatives Ablehnen". In: KüHLweIN, W. \& RAASCH, A. (Org.): Sprache und Verstehen. Band 1. Tübingen, Gunter Narr, 1980, p. 60-68.

HoLLY, Werner - Imagearbeit in Gesprächen. Tübingen, Niemeyer, 1979. ; KÜHN, Peter; PÜSCHEL, Ulrich - Politische Fernsehdiskussionen Zur medienspezifischen Inszenierung von Propaganda als Diskussion. Tübingen, Niemeyer, 1986.

House, Juliane - "Interaktionsnormen in deutschen und englischen Alltagsdialogen". In: Linguistische Berichte 59, 1979, p. 76-90.

\& KASPER, Gabrielle - "Politeness Markers in English and German". In: Coulmas, F. (Org.): Conversational Routine. The Hague/Paris/ New York, Mouton, 1981, p. 157-185. 
KeIM, Inken \& Schwitalla, Johannes - "Soziale Stile des MiteinanderSprechens. Beobachtungen zu Formen der Konfliktbearbeitung in zwei Frauengruppen". In: Selting, Margret \& HennEnKamP, Volker (Org.): Stil und Stilisierung. Tübingen, Niemeyer, 1989, p. 83-121.

KoHnEN, Thomas - Zurückweisungen in Diskussionen. Die Konzeption einer Sprechhandlungstheorie als Basis einer empirisch orientierten Konversationsanalyse. Frankfurt, Peter Lang, 1987.

Kotтhoff, Helga - "Disagreement and Concession in Disputes: On the Context Sensitivity of Preference Structures". In: Language and Society 22, 1993, p. 193-216.

- "Stilunterschiede in argumentativen Gesprächen oder zum Geselligkeit von Dissens". In: Selting, M.\& Hennenkamp, V. (Org.)

- Stil und Stilisierung, Tübingen, Niemeyer, 1989, p. 187-202.

- "So nah und doch so fern - Deutsch-amerikanische pragmatische Unterschiede im universitären Millieu". In: Info DaF 16, 1989(a), p. 448-459.

LAKOFF, George - "Hedges: a Study in Meaning Criteria and the Logic of Fuzzy Concepts". In: $\boldsymbol{C L S} \boldsymbol{8}, 1972$, p. 183-227.

LAKOFF, Robin - "The Logic of Politeness: or; minding your P's and Q's". In: Papers from the 9th Regional Meeting of the Chicago Linguistic Society, Chicago, Chicago Linguistic Society, 1973, p. 292-305.

LANG, Willi - Aspekte der Höflichkeit: Überlegungen am Beispiel der Entschuldigungen im Deutschen. Frankfurt a.M., Peter Lang, 1984.

LAUERBACH, Gerda - "Face-work in Reparaturen - Ein Charakteristikum von Learner-Native-Speaker Diskursen". In: L.A.U.T., Series B, Paper Nr. 81, Trier, 1982, p. 1-23.

LEECH, Geoffrey N. - Principles of Pragmatics. London/New York, Longman, 1983.

Linke, Angelika; Nussbaumer, Markus; Portmann, Paul - Studienbuch Linguistik. Reihe Germanistische Linguistik, 121. Tübingen, Niemeyer, 1991.

LÜTTEN, Juta - "Die Rolle der Partikeln doch, eben und ja als KonsensusKonstitutiva". In: WEYDT, Harald: Die Partikeln der deutschen Sprache. Berlin/New York, de Gruyter, 1979, p. 30-38.

LYONS, John - Semantics. vol 1 e 2, London/New York/Melbourne, Cambridge University Press, 1978 ( $1^{\text {a }}$ ed. de 1977).

MarCuSChi, Luis Antonio - Análise da Conversação. Ática, São Paulo, 1986.

Matsumoto, Y. - "Reexamination of 'face' ". In: Journal of Pragmatics 12, 1988, p. 403-426.

MEIRELES, Selma M. - A negação sintaticamente explícita em diálogos falados do português $\boldsymbol{e}$ do alemão. Dissertação de mestrado (não publicada), São Paulo, FFLCH/USP, 1991. 
MeIRELES, Selma M. \& BlÜHDORN, Hardarik - "O campo inicial da frase e a estrutura informacional do texto". In: Pandaemonium Germanikum. São Paulo, Humanitas, Nr.1, 1997, p.121-162.

ÖHLSCHLÄGER, Günther - Zur Syntax und Semantik der Modalverben des Deutschen. Tübingen, Niemeyer, 1989.

Perelman, Chaim - Tratado da argumentação: A Nova Retórica. São Paulo, Martins Fontes, 1996.

POLENZ, Peter von - Deutsche Satzsemantik: Grundbegriffe des Zwischen-den-Zeilen-Lesens. Berlin/New York, de Gruyter, 1985.

PommeranZ, Anita - "Agreeing and Disagreeing with Assesments - some Features of preferred/dispreferred Turn Shapes". In: ATKINSON, J.M. \& Heritage, J. (Org.) - Structures of Social Action. Cambridge, Cambridge Univ. Press, 1984, p. 57-101.

RALL, Marlene - "Von der Freundlichkeit in der Welt: Über die phatische Funktion der Sprache im interkulturellen Dialog". In: Die Unterrichtspraxis/Teaching German. American Association of Teachers of German, Vol.29, Nr. 1, 1996, p. 12-20.

RosA, Margaret de Miranda - Marcadores de atenuação. São Paulo, Contexto, 1992.

Rosengren, Inger - "ABER als Indikator des Widerspruchs". In: MÜLLER, U. u.a. (Org.) - Göppinger Arbeiten zur Germanistik, Sonderdruck aus Nr. 423. Göppingen, Kümmerle, 1984.

SARCINELLI, Ulrich (Org.) - Demokratische Streitkultur. Bonn, Bundeszentrale für politische Bildung, 1990.

SCHUlzE, Rainer - Höflichkeit im Englischen. Tübingen, Gunter Narr, 1985.

SCHWARZ, Monika - Kognitive Semantiktheorie und neuropsycholinguistische Realität. Tübingen, Niemeyer, 1992.

SCHWITALLA, Johannes - "Über Formen des argumentativen Widerspruchs". In: SCHECKER, Michael (Org.) - Theorie der Argumentation. Tübingen, Gunter Narr, 1977, p. 27-53.

- "Widersprechen in Praxi. Eine Meta-Antwort an Öhlschläger". In: SCHECKER, Michael (Org.) - Theorie der Argumentation. Tübingen, Gunter Narr, 1977(a), p. 65-74.

SEARLe, John R. - "Indirect speech acts". In: Cole, Peter \& Morgan, Jerry (Org.) - Syntax and Semantics. Vol. 3: Speech Acts. New York, Academic Press, 1975, p. 59-82.

SIMÕES, José S. - Marcadores interacionais e modalizadores do português $\boldsymbol{e}$ do alemão falados. Dissertação de mestrado (não publicada). São Paulo, FFLCH/USP, 1997.

SOMMERFELDT, Karl-Ernst et al. - Grammatisch-semantische Felder. Berlin/ München/Leipzig, Langenscheidt/Verlag Enzyklopädie, 1991. 
SoRNIG, Karl - "Disagreements and Contradictions as Communicative acts". In: Journal of Pragmatics 1, 1977, p. 347-373.

SPERBER, Dan \& WILSON, Deirdre: Relevance - Communication and Cognition. Blackwell, Oxford, 1986.

SPRANZ-FOGASY, Thomas - 'Widersprechen' - zu Form und Funktion eines Aktivitätstyps in Schlichtungsgesprächen; eine gesprächsanalytische Untersuchung. Tübingen, Gunter Narr, 1986.

Steger,H.; Engel,U.; Moser,H. (Org.) - Heutiges Deutsch. Reihe II Texte gesprochener Standardsprache II (1974) e III (1976). München, Hueber.

TAGnIN, Stella O. - Expressões idiomáticas e convencionais. São Paulo, Ática, 1989.

Watts, R.; IDE, S.; Ehlich, K. (Org.) - Politeness in Language: Studies in its history, theorie and practice. Berlin/New York, de Gruyter, 1992.

WeInRICH, Harald - Sprache in Texten. Cap. IV - Negationen in der Sprache. Stuttgart, Klett, 1976, p. 63-89.

- Lügt man im Deutschen, wenn man höflich ist? Mannheim/Wien/ Zürich, Bibliographisches Institut, 1986.

Weydt, Harald (Org.) - Partikeln und Interaktion. Tübingen, Niemeyer, 1983.

YAMASHITA, Hitoshi - "Hörerspezifische Höflichkeitsformen". In: Deutsch als Fremdsprache, Heft 3, 1993, p. 145-151. 


\begin{abstract}
ANEXO
No Anexo, encontram-se as ocorrências de Dissensão que compõem o corpus da pesquisa, bem como a indicação e eventual descrição das
\end{abstract} Estratégias de Trabalho da Face e dos meios lingüísticos utilizados para sua expressão.

As ocorrências de Dissensão estão separadas por inquérito, os quais são brevemente identificados ao início de cada um, incluindo duração, número de participantes e o volume da série Heutiges Deutsch no qual foi publicado.

$\mathrm{Na}$ transcrição das ocorrências de Dissensão e das Estratégias de Trabalho da Face, são utilizadas as seguintes convenções ${ }^{32}$ :

1. ao início da ocorrência encontram-se por vezes, entre colchetes, partes da intervenção anterior do interlocutor ou uma pequena contextualização sobre a contribuição do interlocutor que deu motivo a expressão da Dissensão por parte do falante;

2. em itálico, a contribuição do falante que configura a Dissensão; ao final da mesma, entre parênteses, estão a sigla do inquérito e o número da ocorrência, determinado pela sua seqüência cronológica no inquérito original.

3. dentro da ocorrência de Dissensão, reticências entre colchetes $([\ldots])$ marcam trechos da contribuição do falante que, por motivo de espaço e de pouca relevância para o estudo, foram omitidos;

4. foram mantidas algumas características da transcrição original dos inquéritos, como o uso de minúsculas para o pronome pessoal Sie e seus derivados, o uso de parênteses para isolar Satzwörter e comentários dos falantes e a notação $+\mathrm{g}+$ para sinalizar fragmentos de palavras ou sílabas como ah, eh, ahn, uhn etc.

\footnotetext{
${ }^{32}$ Explicações mais detalhadas sobre as convenções encontram-se nas páginas 92 a 94, quando da primeira menção de excertos dos diálogos do corpus.
} 
5. após a transcrição da ocorrência de Dissensão, as Estratégias de Trabalho da Face nela utilizadas são listadas segundo sua superestratégia de base, a saber:

OFF/b: $\quad$ Estratégias off record utilizadas como base para a expressão da Dissensão

DIR: $\quad$ Expressões diretas da Dissensão, sem ação de compensação

COMP+: $\quad$ Estratégias de Compensação Positiva

COMP-: Estratégias de Compensação Negativa

OFF/aux: Estratégias off record utilizadas como auxiliares na expressão da Dissensão

6. dentro de cada uma destas super-estratégias, encontram-se discriminadas em negrito as estratégias formais utilizadas na expressão da Dissensão e em itálico, sua realização lingüística; eventualmente, encontram-se aqui também comentários sobre casos específicos.

7 As siglas ao início das ocorrências indicam a sua categoria de Dissensão, conforme esta se refere:

FORM - à Expressão Lingüística;

FORM/Strat. - ao Uso Estratégico da Dissensão referente à Expressão Lingüística;

PROP/P - $\quad$ a Parte da Proposição;

PROP/T - à Totalidade da Proposição;

INT. - ao Rumo da Interação. 
Inquérito: ABORTO; Duração: 37'30"; Participantes: 6 (4 homens, 2 mulheres); Ocorrências de Dissensão: 31

(PROP/T) Frau Dr. Runge in manchen Punkten kann ich ihnen Recht geben in vielen allerdings nicht. zunächst einmal haben sie einen Punkt völlig vernachlässigt... (ABO1)

DIR: allerdings, nicht

COMP+: in manchen... recht geben - in vielen allerdings nicht - evite discordância: concorde simbolicamente

(PROP/T) also darf ich ihnen sagen, daß ich mit ihnen in dem Punkt voll übereinstimme [...] insofern haben sie mein Ja. nur: stimme ich mit ihnen nicht überein in ihrer These, daß... (ABO2)

DIR: nicht übereinstimmen

COMP+: in dem Punkt voll übereinstimme...insofern... mein Ja. nur... nicht - - busque concordância: relativize a própria opinião (Dissensão apresentada como restrita a um ponto)

COMP-: ich darf sagen... - utilize formas convencionalizadas

(PROP/T) ich kann erstens (jetzt) keine authentische Erklärung geben dafür, warum die DGG eine so konservative (wie sie sagen) Einstellung einnimmt [...] aber (zweitens) möchte ich sagen, daß diese Einstellungsnahme der Frauenärzte Deutschlands [...] diese Einstellung gar nicht so konservativ ist, und für eine Reform nicht im Sinne einer ersatzlosen Abstreichung a:ber im Sinne einer Änderung der Indikationen dann finde ich das nicht nur: konservativ. sie haben zwar sehr konservativ gesagt... (ABO3)

DIR: aber

COMP+: gar nicht so/nicht nur: konservativ - evite discordância: relativize a opinião do interlocutor; und für eine Reform... dann... - dê (ou peça) razões

COMP-: möchte ich sagen... - utilize formas convencionalizadas

OFF/aux: wie sie sagen - dê pistas para associações - já se sabe que ele disse isso implicações: o falante se distancia da opinião - discorda do interlocutor

(PROP/T) das klingt ja, als ob ein Abtreibungszwang: angestrebt würde, und darum geht es doch gar nicht. (ABO4)

DIR: doch, gar nicht

(PROP/T) (nein) das soll eine objektive Fragestellung sein. (ABO5)

DIR: nein

COMP-: soll... sein - afastamento epistêmico: utilize verbos modais

(PROP/T) denn: ich meine ein Embryo eine befruchtete Eizelle ist nicht mehr eigener

Körper der Frau sondern ist schon etwas anderes. (ABO6)

DIR: nicht... sondern

COMP-: ich meine - relativize a própria opinião 
(PROP/T) obwohl sie praktisch abhängig ist vom Kreislauf der Mutter und in der nur: in der Mutter existieren kann... (ABO7)

DIR: obwohl + argumento contrário

COMP-: praktisch - relativize a própria opinião

(PROP/T) [ist der vergeudete Samen schon Leben?] Nein. weder Eizelle noch die Samenzelle allein ist ein neues Lebewesen. (ABO8)

DIR: nein; weder... noch

(PROP/T) [daß es sich um Leben handelt dürfte unbestritten sein] Das wird ja nicht bestritten das wird nicht bestritten. (ABO9)

DIR: $n i c h t$

$\mathrm{COMP}+$ : $j a$ - crie/pressuponha pontos comuns

COMP-: wird nicht bestritten - impersonalize: gerencie a dêixis pessoal

(INT) ich danke (Herr Heer) (also) ...ahn... behalten sie ihren Atem für die nächste Runde. (ABO10)

OFF: dê pistas para associações - o intercutor não está cansado, por que guardar o fôlego? - implicação: deve calar-se no momento e passar a palavra.

COMP-: danke - dê deferência

(PROP/T) ich möchte zunächst sagen davon, daß andere Menschen Unrecht begehen, kann man nicht das Recht herleiten, daß auch wir Unrecht tun sollen... (ABO11)

DIR: argumento contrário

COMP-: ich möchte sagen... - utilize formas convencionalizadas; daß andere

Menschen... kann man nicht... tun sollen - invoque regras gerais

(PROP/T) das ist ja trotzdem möglich die Freiheit der Entfaltung der Persönlichkeit. wir haben ja andere Mittel um die Persönlichkeit frei entfalten zu können... (ABO12)

DIR: trotzdem

$\mathrm{COMP}+:$ ja - crie/pressuponha pontos comuns; es ist trotzdem möglich... - evite discordância: relativize a opinião do interlocutor; wir haben andere Mittel... zu können - dê (ou peça) razões

(PROP/T) und hier möchte ich auch darauf kommen, die Aktualität, die jetzt der Abtreibung gezollt wird, ist gar nicht so groß [...] vielleicht mag es darauf zurückzuführen sein, daß die sogenannte Dunkelziffer größer geworden ist, aber sicher auch darauf, daß die Abtreibung nicht mehr das: Problem ist, wie es früher war... (ABO13)

DIR: nicht

COMP+: gar nicht so gro $\beta$ - evite discordância: relativize a opinião do interlocutor; es mag... sein, aber... - evite discordância: concorde simbolicamente

COMP-: vielleicht - relativize a própria opinião; ich möchte darauf kommen - utilize formas convencionalizadas

(PROP/T) die Tatsache [...] daß verhältnismäßig wenig ... ahn ... derartiger Straftaten zur Anzeige und Aburteilung kommen, macht keineswegs die Strafvorschrift unnötig. (ABO14) 
DIR: proposição contrária

COMP+: das verhältnismäßig wenig... macht keineswegs... - evite discordância: concorde simbolicamente

(PROP/T) ich glaube doch, daß es widersinnig ist, denn ... ahn... wenn die Justiz die Frauen [...] verfolgen würde, müßte man mit zwei bis fünf Millionen

Abtreibungsprozessen rechnen. das heißt die Justiz wäre völlig lahmgelegt. ...ahn... in der Tat haben zum Beispiel 1969 die Behörden nur in insgesamt 1005 Fällen ...ahn... ermittelt. das heißt die Bestrafung ist also völlig willkürlich. das ist eine groteske Angelegenheit... (ABO15)

DIR: doch, widersinnig, willkürlich, grotesk

$\mathrm{COMP}+$ : denn... - dê (ou peça) razões; also - crie/pressuponha pontos comuns

COMP-: ich glaube - relativize a própria opinião

(PROP/T) (also) sicher ist es eine bedauerliche Erscheinung [...] aber das haben wir auf andern Gebieten auch... (ABO16)

DIR: aber

COMP+: sicher... aber - evite discordância: concorde simbolicamente

(PROP/T) es steht beispielsweise eindeutig fest (insofern da muß ich ihnen (Frau Dr. Brandenburg) widersprechen), daß ...ahn... der Begriff Leibesfrucht im Sinne des Gesetzes 1871 so verstanden worden ist, wie sie es sagen, nämlich Befruchtung... (ABO17)

DIR: widersprechen

COMP-: muß widersprechen - indique relutância

(EXTM/Strat) darf ich etwas zum Begriff Leibesfrucht sagen? ich habe diesen Ausdruck nicht gebraucht, sondern ich habe gesagt... (ABO18)

DIR: nicht... sondern

COMP-: darf ich ...? - dê deferência; diesen Ausdruck - defocalize os participantes

(PROP/T) und zweitens möchte ich ihnen entgegnen (Herrn Müller-Emmert) die neuen biologischen Erkenntnisse sind doch keinesfalls am Ende... (ABO19)

DIR: entgegnen, doch keinesfalls

COMP-: ich möchte... - utilize formas convencionalizadas

(INT) darum geht es doch nicht (Herr Losotz) es geht im den doch darum... (ABO20)

DIR: doch nicht

(PROP/T) (doch) (sie sagten s ja gerade) (ABO21)

DIR: doch

COMP+: sie sagten... - dê (ou peça) razões; $j a$ - crie/pressuponha pontos comuns 
(PROP/T) (Herr Prof. Heer) ich würde ihnen da ...ahn... sie verteidigen so sehr die Frau und ich möchte von daher als Frau dazu Stellung nehmen. ich würde ihnen also ganz entschieden widersprechen, was die Personenwürde der Frau angeht. die sehe ich zum Beispiel völlig anders ... (ABO22)

DIR: völlig anders, widersprechen COMP+: sie verteidigen... dazu Stellung nehmen - dê (ou peça) razões

COMP-: ich sehe zum Beispiel - relativize a própria opinião; ich würde ihnen widersprechen - gerencie o grau de realidade

OFF/aux: sie verteidigen so sehr die Frau - seja irônico - a falante realmente não acha que ele defenda as mulheres.

(PROP/T) [und zwar würde ich sagen, die Frau steht heute davor, ihre Befreiung sich zu erringen...] (liebe liebe gnädige Frau) sie mißverstehen mich ja völlig [...] die erste Emmanzipationsbewegung hat zu einer gewissen Einpassung der Frau in eine männlich orientierte Leistungsgesellschaft geführt und hat nur zu einem minderen Teil der Frau wirklich dazu verholfen den ganzen Großraum ihrer Verantwortung wahrnehmen zu können. ich bin ja nicht dafür. verzeihen sie, daß ich ...(ABO23)

DIR: mißverstehen

COMP+: die erste Emanzipationsbewegung...nicht dafür - dê (ou peça) razões; ja crie/pressuponha pontos comuns

COMP-: liebe gnädige Frau - dê deferência; Sie mißverstehen mich... - minimize a imposição; verzeihen Sie - peça desculpas

(PROP/T) und dann möchte ich noch sagen zu der Diskussion um das werdende Leben ...ahn... (Frau Dr.) da sollten sie doch eigentlich wissen (da möchte ich mich ihnen anschließen), daß die Frage an sich schon ...ahn... falsch gestellt ist... (ABO24)

DIR: doch, falsch

COMP-: sie sollten... wissen - afastamento epistêmico: utilize verbos modais + gerencie o grau de realidade; eigentlich, an sich - relativize a própria opinião; die Frage - defocalize os participantes

(PROP/T) [Leben ist schon im Ei...] (nee) (nein) das kann man aber wirklich nicht sagen, das ist biologisch falsch. (ABO25)

DIR: nee, nein, aber

COMP-: das kann man nicht sagen - invoque regras gerais; biologisch falsch - apele à autoridade/objetividade

(PROP/T) (nein) ich glaube ich möchte noch mal zu der Aktion und zwar ich möcht noch mal zu ihnen sagen [...] solange dieser Paragraph besteht [...] und solange, wie eben die Ärzte sich abgeschreckt fühlen ist auch dieser Paragraph für Deutschland noch sehr gültig, auch wenn nur wenige bestraft werden (ABO26)

DIR: nein

COMP+: solange dieser Paragraph... abgeschreckt fühlen - dê (ou peça) razões; auch wenn... bestraft werden - busque concordância - relativize a própria opinião

COMP-: ich möchte sagen - utilize formas convencionalizadas 
(INT) wir wollen hier keine Wiederholung machen. wir können nicht immer ein und dasselbe Argument, was hier Frau Dr. Runge vorgetragen hat schon, noch mal wiederholen. darfich sie bitten? (ABO27)

DIR: keine, nicht wiederholen

$\mathrm{COMP+:} \mathrm{wir} \mathrm{können} \mathrm{nicht} \mathrm{immer...} \mathrm{wiederholen} \mathrm{-} \mathrm{dê} \mathrm{(ou} \mathrm{peça)} \mathrm{razões;} \mathrm{wir}$ wollen/können... - inclua falante e interlocutor na atividade: gerencie a dêixis pessoal

(PROP/T) ich möchte mich dagegen wehren, daß Frau Dr. Runge und auch meine beide Vorrednerinnen diese Leute in England, die auf Bestellung ungeborene Kinder abmurksen, als Ärzte bezeichnen...(ABO28)

DIR: sich dagegen wehren

COMP-: ich möchte... - utilize formas convencionalizadas

OFF/aux: dê pistas para associações - associações negativas com os termos diese Leute in England, abmurksen

(PROP/T) [...Ärzte fühlen sich in dieser Beziehung ihrem hypokratischen Eid verpflichtet] da muß ich sie unterbrechen (Kollegin). Hypokrates hat davon nichts gesagt (ja?). also man darf den Arztberuf nicht überideologisieren sondern wir müssen tatsächlich auch gesellschaftspolitisch auf dem Stand unseres Wissens sein. [...] aber ich sage das nur um ihnen zu sagen, daß sie das Arztprinzip nicht überdehnen sollen für ideologische Zwecke. (ABO29)

DIR: nichts

$\mathrm{COMP}+$ : Kollegin - utilize marcadores de identidade grupal; (ja?) -

crie/pressuponha pontos comuns; aber ich sage das nur... ideologische Zwecke - dê (ou peça) razões; wir müssen... - inclua falante e interlocutor na atividade: gerencie a dêixis pessoal

COMP-: da muß ich sie unterbrechen - indique relutância; man darf nicht... impersonalize: gerencie a dêixis pessoal

(INT) [darf ich etwas sagen] allerdings (nein) ich möchte das: jetzt sofort erwidern (ABO30)

DIR: allerdings, nein

$\mathrm{COMP}+$ : ich möchte... erwidern - dê (ou peça) razões

(PROP/T) ich glaube, daß sie als Arzt dann als Patient dann, wenn es ihnen ans eigene Leder geht [...] sie müssen dann zwei Leute halten für den persönlichen Gebrauch einen, der es nicht so wichtig nimmt [...] und einen anderen, den sie einsetzen, wenn sie sich bedroht fühlen. vereinigen läßt sich das meiner Ansicht nach nicht. als Arzt fühle ich mich dem Leben verpflichtet. (ABO31)

OFF: dê pistas para associações - wenn es Ihnen ans eigener Leder geht... - dois tipos de médico: os que fazem aborto e os que não - implicação: para uso próprio, a interlocutora não iria querer um médico que não se importasse com a vida; vereinigen läßt sich das... mich dem Leben verpflichtet - não se pode juntar os dois procedimentos; a falante é médica e tem compromisso com a vida - implicação: quem pensa de outro modo (p.ex. a interlocutora) não é realmente um médico.

COMP-: ich glaube, meiner Ansicht nach - relativize a própria opinião 
Inquérito: Alemão; Duração: 42'10"; Participantes: 6 (5 homens, 1 mulher); Ocorrências de Dissensão: 16

(PROP/P) [Obersekunda] (na) Untersekunda (ALE1)

DIR: (na) + informação correta

(PROP/T) [...um überhaupt einen vernünftigen Deutschunterricht zu machen] ich glaube, daß man zwar immer einige Einfälle haben muß, um einen guten

Deutschunterricht zu machen denn der Deutschunterricht hängt weitgehend ja auch vom Lehrer ab. aber ...ahn... ich glaube (und da spreche ich nun in eigener Sache) (und ich habe an vielen Richtlinien seit 1945 mitgearbeitet) wir haben jedenfalls versucht: die Richtlinien so zu gestalten ...ahn..., daß sie nicht so katastrophal würden, wie uns hier eben erzählt worden ist. (ALE2)

DIR: aber

COMP+: denn der Deutschunterricht... auch vom Lehrer ab - dê (ou peça) razões; ...hängt ja auch... - crie/pressuponha pontos comuns; nicht so katastrophal - evite discordância: relativize a opinião do interlocutor COMP-: ich glaube - relativize a própria opinião; ... erzählt worden ist impersonalize: gerencie a dêixis pessoal

(PROP/T) ...ahn... (also) ...ahn... gerade von studentischer Seite sind ja gerade diese Richtlinien immer wieder angegriffen worden und ich glaube sie sind ja sehr verschie:den in den verschiedenen Ländern (manchmal glaube ich) zu recht angegriffen worden... (ALE3)

OFF: (manchmal glaube ich) zu recht angegriffen worden - dê pistas para associações - o falante refere-se aos estudantes, mas coloca-se junto a eles, mesmo sabendo que a interlocutora participou da elaboração das linhas-mestras - implicação: ele discorda da interlocutora.

$\mathrm{COMP}+$ : sind ja gerade... - crie/pressuponha pontos comuns

COMP-: ich glaube, manchmal - relativize a própria opinião

(PROP/T) (ja) ich möchte erst mal eine Bemerkung zu Herrn Pehlke machen. je enger und strenger solche Richtlinien sind (Rahmenrichtlinien für den Unterricht) ...ahn... desto ...ahn... weniger Möglichkeiten sind auch einer Mitbestimmung der Schüler eingeräumt... (ALE4)

OFF: je enger...der Schüler eingeräumt - dê pistas para associações - é importante que os alunos tenham participação nas decisões, o que é difícil com linhas-mestras mais rígidas - implicação: falante discorda da sugestão.

COMP-: ich möchte... - utilize formas convencionalizadas; eine Bemerkung machen minimize a imposição 
(PROP/T) (ja) und das, was Herr Riha sagte, (vielleicht ein Kommentar) und ich finde das ist gut: so in der BRD. Lern:zielentscheidungen sind: nun einmal politische Entscheidungen [...] aber diese Konkurrenzsituation hat ja etwas Gutes. (ALE5)

OFF: das ist gut: so, ... sind: ... hat etwas Gutes - dê pistas para associações - o interlocutor apresentou o termo "resoluções politicas" em um contexto implicitamente negativo; através da entonação, o falante deixa claro que acha o fato positivo implicação: falante discorda do interlocutor.

COMP+: nun einmal, hat ja... - crie/pressuponha pontos comuns

COMP-: vielleicht ein Kommentar - minimize a imposição; ich finde - relativize a própria opinião

(PROP/T) [...] ich weiß nicht, ob das immer etwas Gutes ist (nich?) ich will man kann es doch wohl kaum als gut bezeichnen, wenn in ganz bestimmten Ländern eben noch sehr rückschrittliche Tendenzen herrschen. (ALE6)

DIR: doch, kaum, rückschrittlich

COMP+: ob immer... - evite discordância: relativize a opinião do interlocutor; $n i c h$ ?, eben - crie/pressuponha pontos comuns

COMP-: ich weiß nicht - utilize formas convencionalizadas; man kann es...impersonalize: gerencie a dêixis pessoal; wohl - relativize a própria opinião OFF/aux: in ganz bestimmten Ländern... - seja vago

(PROP/T) (ja) (Herr Höllerer) sie können sich ja nun an die Wand malen, was passiert wäre, wenn die Rah:menrichtlinien für den Deutschunterricht von 1949 bis 1966 ausgesehen hätten, wenn Herr Würmeling Bundeserziehungsminister gewesen wäre. (ALE7)

OFF: sie können sich... gewesen wäre - dê pistas para associações - conhecendo o Sr. Würmeling sabe-se quais são suas idéias, as quais o falante aparentemente não aprova implicação: o falante discorda da sugestão do interlocutor.

COMP+: ja nun - crie/pressuponha pontos comuns

(PROP/T) [nur Fachleute haben die Richtlinien bestimmt] (Herr Pelke) der ...ahn... Deutschunterricht hat ja im: Zusammenhang mit dem gesamten schulischen Kanon eine bestimmte Funktion [...] die ist gründlich zu überprüfen bin ich völlig mit ihnen einer Meinung nur bevor: diese Fachkommissionen für Deutsch für Mathematik für Biologie ans Werk gingen, waren all:gemeine Lernziele vor:gegeben zur Diskussion gestellt, zu der dann zu denen dann die ein:zelnen Fächer bestimmte Beiträge zu ...ahn... zu liefern haben ...ahn... (das heißt also) wir haben nicht: so angefangen wie üblicherweise Rahmenpläne gestrickt werden ...ahn... daß die Fachleute freiweg auf freiem Feld losmarschieren, sondern erst: allgemeine Lernziele der Schule und der einzelnen Schultypen... (ALE8)

OFF: wir haben nicht: so angefangen... losmarschieren - dê pistas para associações o interlocutor manifestou-se contra o fato de as linhas-mestras terem sido definidas por técnicos, sem participação da comunidade escolar; o falante acentua que essa comissão, da qual fez parte, não agiu como a maioria das demais, iniciando os trabalhos sem qualquer base - implicação: o falante discorda do interlocutor sobre a equipe técnica não ter feito um trabalho adequado à realidade.

COMP+: ich bin völlig.... nur... - evite discordância: concorde simbolicamente; bevor: diese Fachkommission...der einzelnen Schultypen - dê (ou peça) razões 
(PROP/T) aber die waren politisch definiert (ALE9)

DIR: aber

OFF/aux: dê pistas para associações - o falante apresenta um fato conhecido de ambos, precedido por um elemento semanticamente negativo - implicação: o falante considera a definição política das linhas-mestras como um fato negativo.

(PROP/T) die waren politisch definiert. die waren öffentlich diskutiert standen zur Diskussion sind durch einen ...ahn... durch den Erziehungsbeirat des Landes Berlin gegangen, in dem auch nun Nichtlehrer in großer Zahl sitzen ...ahn... so daß ...ahn... Transparenz und Öffentlichkeit hergestellt war. (ALE10)

COMP+: politisch definiert - repetição e nova interpretação - evite discordância: relativize a opinião do interlocutor; standen zur Diskussion... hergestellt war - dê (ou peça) razões

(PROP/T) (na) ich mein den Faschismus auszusparen wär ja völlig falsch (nich?) (ALE11)

DIR: falsch

COMP+: ...ja völlig..., nich? - crie/pressuponha pontos comuns

COMP-: ich mein - relativize a própria opinião; ... wär völlig falsch - gerencie o grau de realidade; den Faschismus auszusparen - impersonalize: gerencie a dêixis pessoal

(PROP/T) [die alten Pläne werden aussortieren, zur Seite gelegt] [...] ich meine, daß politische Wirkungen ...ahn... solcher Rahmenpläne nur zu erreichen ist, wenn dort, wo: es möglich ist [...] daß man nicht den Weg ...ahn... über den Kompromiß geht oder über den Papierkorb ...ahn..., wie sie sagten (Herr Evers), daß man also das, was dann überholt ist, ...ahn... in den Papierkorb ...ahn... wirft und eben was Neues macht, sondern vernünftiger ist doch dann ein zunächst mal ganz klar progressive Ziele zu formulieren... (ALE12)

DIR: nicht

$\mathrm{COMP}+$ : politische Wirkungen... nur zu erreichen sind, wenn... progressive Ziele zu formulieren - dê (ou peça) razões

COMP-: ich mein - relativize a própria opinião

(EXTM) ...ahn... politischen Sog würde ich sagen, nicht politischen ...ahn... Druck (ja?) ...ahn... (ALE13)

COMP+: (ja?) - crie/pressuponha pontos comuns

COMP-: würde ich sagen - gerencie o grau de realidade

(PROP/T) [Eindruck, man solle eine Stunde lang Gebrauchtexte üben] es wird nur das Formale angesprochen ...ahn... in welcher Form. aber es wird auf keinen Fall verlangt, das man das eine Stunde lang macht, sondern, daß es un:ter anderem und daß die anderen kritisch sich dazu äußern... (ALE14)

DIR: aber, auf keinen Fall

$\mathrm{COMP}+$ : daß es un:ter anderem... - evite discordância: relativize a opinião do

interlocutor; es wird nur das Formale angesprochen - dê (ou peça) razões 
(PROP/T) [das rutscht wieder in den alten Unterricht] (nein) das ...ahn... zum Beispiel ...ahn... is ...ahn... im Rahmenplan zwei Gesichtspunkte aufgeführt worden und zwar ein ....ahn... ein literarisches Werk unter inner:literarischen Aspekten zu besprechen und aus au:ßerliterarischen Aspekten das käme dann auf so zu kulturelle Situationen und so weiter hinein (ALE15)

DIR: nein + exemplo contrário

COMP+: zum Beispiel... - dê (ou peça) razões

(PROP/T) (ja) es besteht halt bloß die Schwierigkeit dabei, daß man mit ...ahn... (sozusagen) organisatorischen Kriterien wie Rückkoppelung eigentlich gar nichts erledigt... (ALE16)

DIR: gar nichts

$\mathrm{COMP}+$ : halt - crie/pressuponha pontos comuns

COMP-: $d a \beta$ man... nichts erledigt - invoque regras gerais; eigentlich - relativize a própria opinião

OFF/aux: es besteht bloß die Schwierigkeit - seja irônico - a dificuldade é apresentada como pequena, embora inviabilize totalmente a opinião do interlocutor. 
Inquérito: Almôndegas; Duração: 29'34"; Participantes: 6 (5 homens, uma mulher); Ocorrências de Dissensão: 32

(PROP/T) (also) das würde ich nicht. ich mein ...ahn... es mag sicherlich ...ahn... diese ...ahn... (also) diese Definition ist sicherlich richtig und es mag solche ...ahn... Gebilde geben. aber ich kenne Bouletten ...ahn... aus meiner Vergangenheit [...] nur als Lebewesen. (also) ich weiß daß Bouletten ...ahn... das ist etwas unappetitlich das zu sagen (ALM1)

DIR: nicht

COMP+: es mag sicherlich... aber... - evite discordância: concorde simbolicamente; ich kenne Bouletten ... nur als Lebewesen - explicações - dê (ou peça) razões COMP-: ich mein, ich weiß, das zu sagen - relativize a própria opinião; das würde ich nicht - gerencie o grau de realidade;

(PROP/T) darf ich (Herr Honig). ich weiß nicht. sie sind immer gleich so rasch mit ihren Urteilen (ich find) (also) ich mein ich habe auch so $n$ kleines Nest unterm Kühlschrank aber ich finde sie ganz nett... (ALM2)

COMP-: darf ich - dê deferência, ich weiß nicht - utilize formas convencionalizadas; ich find, ich meine - relativize a própria opinião

(PROP/T) wieso immer gleich? wir haben gerade erst angefangen. (ALM3)

$\mathrm{COMP}+$ : wieso? - dê (ou peça) razões

(PROP/T) Herr Thoma wo haben sie eigentlich diese Definition nachgelesen? Fleschbällchen (also) ich weiß nicht ob Bällchen kratzen... (ALM4)

OFF: wo haben sie eigentlich... nachgelesen? - dê pistas para associações: eigentlich em perguntas tem caráter de repreensão (cf. DUDEN: 1983: 313) - implicação: o falante não acha que a definição venha de fonte confiável ou mesmo exista.

COMP-: - evite afirmações: faça perguntas; $i c h$ weiß nicht $o b . .$. - utilize formas convencionalizadas

(PROP/T) aber sie essen doch auch Schweine und jene sind ja auch mal irgendwann lebendig gewesen. (ALM5)

DIR: aber, doch

$\mathrm{COMP}+:$ ja - crie/pressuponha pontos comuns; sie essen doch Schweine...lebendig gewesen - dê (ou peça) razões

(PROP/T) ich wehre mich ein wenig dagegen, daß hier nun gleich hier so eine Verfremdung hineinkommt...(ALM6)

DIR: sich wehren; Verfremdung

COMP-: ein wenig - relativize a própria opinião; so eine Verfremdung - defocalize os participantes

(INT) [...] ja aber wir wolln nicht von Ungeziefern reden. Herr Thoma meint mit dem Thema etwas ganz anders damit. (ALM7)

COMP+: ja aber - evite discordância: concorde simbolicamente; wir wolln nicht... inclua falante e interlocutor na atividade: gerencie a dêixis pessoal; Herr Thoma meint... ganz anders damit - dê (ou peça) razões 
(PROP/T) (doch) unsere Katze frißt sie. (ALM8)

DIR: doch

$\mathrm{COMP}+$ : unsere Katze... - exemplo contrário - dê (ou peça) razões

(PROP/T) mir ist das alles mir ist die Definition zu abrupt und mir ist auch die Interpretation von Herrn Honig zu abrupt. [...] Boulette ist nicht nur eine Fleischspeise. Boulette ist nicht nur dieses [...], sondern ich glaube es gibt viele Möglichkeiten von Bouletten... (ALM9)

COMP+: nicht nur...sondern, viele Möglichkeiten - evite discordância: relativize a opinião do interlocutor

COMP-: mir ist, ich glaube - relativize a própria opinião; Definition, Interpretation defocalize os participantes; ist zu abrupt - minimize a imposição

(PROP/T) Widerspruch ...ahn... wenn ich ...ahn... (Entschuldigung) wenn ich sage ich glaube doch, daß hier nach den neusten etymologischen Forschungen ein Irrtum vorliegt ...ahn... ich glaube nicht ...ahn... daß die Herkunft [...] sondern daß... (ALM10)

DIR: Widerspruch, Irrtum, doch

COMP-: Entschuldigung - peça desculpas; ich glaube - relativize a própria opinião; nach... Forschungen - apele à autoridade/objetividade; ein Irrtum vorliegt defocalize os participantes

(PROP/T) darf ich mal den den den Gegensatz rauskehren? Es gibt ja auch einen Nebenbuhler (ALM11)

DIR: Gegensatz rauskehren

COMP+: $j a$, crie/pressuponha pontos comuns; $a u c h$ - evite discordância: relativize a opinião do interlocutor

COMP-: darf ich mal...? - dê deferência

(PROP/T) (ja) ich weiß nicht, ob man nun also jetzt also ... ahn... diese Deutung jetzt nun wirklich auf Tischsitten ausdehnen kann, das sind ja schon wieder zwei verschiedene Dinge (nich?) (ALM12)

COMP+: ja schon wieder - crie/pressuponha pontos comuns

COMP-: ich weiß nicht... utilize formas convencionalizadas; ob man... ausdehnen kann - impersonalize: gerencie a dêixis pessoal

(PROP/T) (Frau Linau) ich würde sagen (vorsichtig) wir kommen jetzt auf ein gefährliches Feld. denn der Klops ist rund und die Boulette ist flach. (ALM13)

OFF: vorsichtig, gefährlich - dê pistas para associações - why should she be careful? Implication: she should change her reasoning course.

COMP+: wir kommen... - inclua falante e interlocutor na atividade: gerencie a dêixis pessoal

COMP-: ich würde sagen - gerencie o grau de realidade 
(PROP/T) ist das Neueste, was ich höre (also) die Klopse, die ich immer kriege... (ALM14)

OFF: das Neueste - exagere; die, die ich immer kriege... - dê pistas para associações: round Klopse are a novelty; those, thet she knows... - implication: ... are not like thet disagreement.

(INT) das ist ganz etwas anderes hat damit nichts zu tun. (ALM15)

DIR: etwas anderes; hat nichts zu tun

(PROP/T) [...] (ich mein) ich gebe zu, das ist eine große Ähnlichkeit. aber bringen sie da nicht einiges durcheinander? versteinerte Bouletten? ich mein ...ahn... ich (ALM16)

OFF: versteinerte Bouletten? - repetição + entonação - dê pistas para associações junto ao conceito negativo de durcheinander - implicação: não concordância.

COMP+: ich gebe zu.., aber... - evite discordância: concorde simbolicamente;

bringen sie da nicht.. - negative question - crie/pressuponha pontos comuns

COMP-: ich mein - relativize a própria opinião

(PROP/T) (na) (Delle und Brust) (also) ich mein das ist ja doch ein gewisser

Unterschied (ALM17)

DIR: doch, Unterschied

$\mathrm{COMP}+$ : ja - crie/pressuponha pontos comuns

COMP-: ich mein, ein gewisser - relativize a própria opinião;

(PROP/T) (also) so schön und so so sinnreich und so (fast möcht ich sagen) so innig diese Deutung von Herrn Lenz ist, so entspricht sie doch keineswegs der kulina:rischen Bestimmung dieses Nahrungsmittels... (ALM18)

COMP+: so schön und... doch keineswegs... - evite discordância: concorde simbolicamente

(PROP/T) aber sollte man sich nicht vielleicht überlegen (dieses fri als frei akzeptiere ich) aber vielleicht etwas anders aufschlüsseln... (ALM19)

DIR: aber, etwas anders

COMP+: sollte man sich nicht...? - crie/pressuponha pontos comuns; dieses ... akzeptiere ich aber... - evite discordância: concorde simbolicamente

COMP-: man - impersonalize: gerencie a dêixis pessoal; vielleicht - relativize a própria opinião; sollte... überlegen - afastamento epistêmico: utilize verbos modais + gerencie o grau de realidade

(PROP/T) (ja) und wo lassen sie das N? (ALM20)

OFF: dê pistas para associações - a explicação do interlocutor não contempla o "n" implicação: é incompleta/errônea.

COMP+: (ja) und - evite discordância: concorde simbolicamente; wo lassen sie...? evite afirmações: faça perguntas 
(INT) (nun gut) aber (lieber Herr Lenz) unser Thema heißt ja nicht kann man Frikandellen oder Frikadellen essen sondern kann man Bouletten essen? (ALM21)

COMP+: (nun gut) aber... - evite discordância: concorde simbolicamente; ja crie/pressuponha pontos comuns

OFF/aux: unser Thema heißt ja nicht...... sondern... - dê pistas para associações everyone knows the theme - implications: the interlocutor is deviating from the theme.

(PROP/T) jetzt sind s schon Scheiben. also ich find es wird immer flacher das Ding (ALM22)

OFF: immer flacher - exagere - implicação: estamos nos afastando demais da almôndega, que é esférica.

$\mathrm{COMP}+$ : das Ding - (Umgangssprache) intensifique o interesse: aproxime o interlocutor

COMP-: ich find - relativize a própria opinião; das Ding - defocalize os participantes

(PROP/P) [In Berlin wurde es zum Klops] (nee) in Berlin ja noch nicht (ALM23)

DIR: nee, ja nicht

(PROP/T) [Man könnte mit Bouletten Diskus spielen] das das bezweifle ich. (nein nei) das bezweifle ich. (ALM24)

DIR: nein

COMP-: das bezweifle ich - minimize a imposição

(PROP/T) [man kann Bouletten essen] aber der Weg der Weg ist doch eindeutig jetzt. Herr Lenz hat also sehr einleuchtend beschrieben (wie ich finde) wie also die Frikadelle oder die Frikandelle oder die Boulette den Weg gemacht hat von einem Nahrungsmittel für Notzeiten und dann langsam geworden war zu einem Schmuckstück (ja) so zum [...] Sportgerät. kein Mensch wird ja Sportgeräte und Schmuckstücke essen. (ALM25)

DIR: aber, doch

COMP+: Herr Lenz hat....zum Sportgerät. kein Mensch... essen - argumentos contra a versão culinária - dê (ou peça) razões; ... wird ja... - crie/pressuponha pontos comuns COMP-: wie ich finde - relativize a própria opinião; kein Mensch wird... essen invoque regras gerais

(PROP/T) (ja) (aber Einspruch Einspruch Einspruch) ...ahn... sie sagen Sportgerät. zum Sportgerät gehört zum Beispiel eine Keule und wir essen doch jede Menge Keulen... (ALM26)

DIR: Einspruch, doch + exemplo contrário

$\mathrm{COMP}+$ : (ja) aber - evite discordância: concorde simbolicamente; zum Sportgerät... jede Menge Keulen - arguments: dê (ou peça) razões 
(PROP/T) (wissen sie) da wiederholen sie (also) niemand macht hat das. mit Hammelkeulen hat man nie Wettbewerbe gemacht, sondern da hat man also ... (nich?) (ALM27)

COMP+: wissen sie - intensifique o interesse: aproxime o interlocutor; nich? crie/pressuponha pontos comuns;

COMP-: niemand macht das, ... hat man nie gemacht - invoque regras gerais

(PROP/T) [Kennedy war ein herber Typ] (herber Typ?) ich mein bei bei der Ehefrau würd ich nicht sagen, daß er ein herber Typ ist... (ALM28)

OFF: herber Typ? repetição + entonação - dê pistas para associações -implicação: não-concordância.

COMP+: bei der Ehefrau - dê (ou peça) razões

COMP-: ich mein - relativize a própria opinião; ich würde nicht sagen... - defocalize os participantes

OFF/aux: bei der Ehefrau - dê pistas para associações - associações com a figura da esposa de Kennedy - não é do tipo que ficaria com um homem herb ("áspero").

(INT) aber wir wollen nicht vom Thema abkommen... (ALM29)

DIR: aber

$\mathrm{COMP}+$ : wir wollen nicht... - inclua falante e interlocutor na atividade: gerencie a dêixis pessoal

(PROP/T) [Zum Karneval sollte man Bouletten aus den Wagen werfen] das ist schwer ...ahn... und gefährlich vor allem... (ALM30)

DIR: schwer, gefährlich

COMP+: das ist schwer... und gefährlich - argumentos contra a idéia - dê (ou peça) razões

(PROP/T) [Die Kollegin kann sie vielleicht zum Boulettenessen einladen] (nein) (Herr Honig) meine eigenen sind mir ja ans Herz gewachsen. ich habe doch vorhin schon gesagt die kann: ich nicht schlachten (ALM31)

DIR: nein, kann: nicht..., doch

COMP+: meine eigenen...gewachsen - dê (ou peça) razões; ja - crie/pressuponha pontos comuns

(PROP/T) [wann die da krabbelten](nein) vor allem ich mein diese diese

Unterstellungen sind typisch männlich. ...ahn... sie denken jetzt Bouletten ißt man lebendig. das ist natürlich reiner Unfug. (ALM32)

OFF: typisch männlich - dê pistas para associações - associações: homens não pensam como mulheres - implicação: a falante não concorda.

DIR: nein, Unfug

COMP-: ich mein - relativize a própria opinião; diese Unterstellungen - defocalize os participantes

OFF/aux: das ist reiner Unfug - exagere 


\section{Inquérito: CoALIZÃo; Duração: 36'17"; Participantes: 8 (homens); Ocorências de Dissensão: 36}

(PROP/T) ich darf zunächst sagen (Herr Heizler) sie sagen wir stünden vor schweren Auseinandersetzungen innerhal der SDP. das ist nicht richtig. die haben wir hinter uns. die sind gestern der wesentliche Teil dieser Auseinandersetzungen ist gestern Nacht zwischen 12 und 1 zu Ende gegangen [...] in der Bundestagsfraktion [...] das war schon ...ahn... ein oder zwei Tage vorher. (also) die Auseinandersetzungen [...] sind abgeschlossen... (COA1)

DIR: das ist nicht richtig

COMP+: die haben wir hinter uns. die sind gestern... also... - dê (ou peça) razões COMP-: ich darf sagen - utilize formas convencionalizadas; der wesentliche Teil relativize a própria opinião

(PROP/T) kann man das sagen die Auseinandersetzungen sind abgeschlossen? in einem weiteren Sinne meine ich (COA2)

COMP+: kann man das sagen...? - evite afirmações: faça perguntas

COMP-: im weiteren Sinne, ich meine - relativize a própria opinião

OFF/aux: kann man das sagen - dê pistas para associações - por que não se poderia dizer isso? - implicação: o falante não acha isso correto.

(PROP/T) in den entscheidenden in den entscheidenden Körperschaft der Partei (COA3)

OFF: seja incompleto: na agremiação decisiva do partido (os conflitos acabaram); dê pistas para associações - na parte decisiva, não há mais conflitos - implicação: o falante pode, ao contrário implícito em $C O A 2$, afirmar que não há mais conflitos.

(PROP/T) aber wird es nicht weiter Auseinandersetzungen geben über die Frage? (COA4)

DIR: aber

COMP+: wird es nicht...? - crie/pressuponha pontos comuns

(PROP/T) (nein) (nein) (nein) (nein) (COA5)

DIR: nein

(EXTM/Strat) ich möchte auf das Wort Kapitulation zurückkommen dürfen (Herr Heizler) die Sozialdemokraten haben 17 Jahre lang diese Regierungsfestung be:lagert und diejenigen, die die Festung besetzt hielten [...] und wenn jemand ich finde den Ausdruck Kapitulation schlecht in jedweder Beziehung so rum gesehen wie auch in dem Bilde, das ich gerade gebrauche [...] haben ihre Tore den Belagerern öffnen müssen. so würde ich genauso gut ...ahn... das Bild von der Kapitulation ...ahn... gebrauchen können, wenn wenn das ein angemessenes Wort überhaupt wäre. ich halte es nicht für angemessen. (COA6)

DIR: nicht angemessen, schlecht

COMP+: die Sozialdemokraten haben... öffnen müssen - dê (ou peça) razões

COMP-: ich möchte zurückkommen dürfen - utilize formas convencionalizadas; ich

finde, ich halte es nicht für angemessen - relativize a própria opinião; würde 
gebrauchen..., wenn überhaupt wäre - gerencie o grau de realidade; Bild, Kapitulation - defocalize os participantes

OFF/aux: Regierungsfestung be:lagert, ihre Töre den Belagerern öffnen - use

metáforas; in jedweder Beziehung - exagere

(EXTM/Strat) ich halte den Ausdruck Zugeständnis für falsch (Herr Heizler)... (COA7)

DIR: falsch

COMP-: ich halte für -relativize a própria opinião; Zugeständnis - defocalize os participantes

(INT) aber bleiben wir in Bonn (COA8)

DIR: aber

COMP+: wir - inclua falante e interlocutor na atividade: gerencie a dêixis pessoal

OFF/aux: bleiben wir in Bonn - dê pistas para associações - como eles não estão na cidade de Bonn, o falante só pode se referir ao assunto - implicação: o interlocutor está fugindo do assunto.

(PROP/T) (nein) (nein) (nein) (nein) an den Namen Strauß brauch ich mich nicht zu gewöhnen (COA9)

DIR: nein, nicht

$\mathrm{COMP}+$ : graceje

(PROP/T) [kann die Fraktion überhaupt noch etwas tun?] das kann sie ganz gewiß... (COA10)

DIR: das kann sie - afirmação contrária à idéia implícita na pergunta do interlocutor, sinalizada por überhaupt, de que não seria possível fazer nada.

(PROP/T) [wird das Parlament zur Ohnmacht verurteilt sein?] das hätte mir noch gefehlt (COA11)

OFF: seja irônico

(PROP/T) [Helmut Schmidt als Schutztruppenchef im Bundestag] versprechen sie sich nicht zu viel. versprechen sie sich nicht zu viel. (COA12)

COMP-: versprechen sie sich nicht zu viel - utilize formas convencionalizadas

(PROP/T) mir versprechen sie brauchen sie ...ahn... gar nichts versprechen. (COA13)

DIR: gar nichts

(PROP/T) [...wird die Opposition schützen] aber ...ahn... es ist natürlich nicht an dem, daß die Institution des Parlamentes einfach zur Verfügung der Opposition steht (COA14)

DIR: aber, nicht

$\mathrm{COMP}+$ : natürlich - crie/pressuponha pontos comuns

(PROP/P) nicht nur für uns sondern für $n$ Staat vielleicht (COA15)

DIR: nicht... sondern + informação correta

COMP-: vielleicht - relativize a própria opinião 
(PROP/T) (nein) nicht für den Staat (Herr Kollege Mischnick) also bleiben wir hier bei einfach beim Steuer der Wahrheit. in kei:nem angelsächsischen in keiner

angelsächsischen Demokratie, die nur das sogenannte Mehrheitswahlrecht kennt, kann man sagen, daß es eine Existenzfrage gibt des Staates oder eine Gefahr für den Staat

besteht. (COA16)

DIR: nein, nicht, kein

COMP+: Herr Kollege - utilize marcadores de identidade grupal; bleiben wir... inclua falante e interlocutor na atividade: gerencie a dêixis pessoal

COMP-: in kei:nen... kann man sagen, daß... - invoque regras gerais

OFF/aux: beim Steuer der Wahrheit - use metáforas

(PROP/T) aber Schweiz Schweden und so weiter funktioniert auch ohne Mehrheitswahlrecht (COA17)

DIR: aber

COMP+: exemplo contrário - dê (ou peça) razões

(PROP/T) (ja) (schön) bis jetzt hat s bei uns auch funktioniert aber man kann nicht sagen... wenn man die Organisation verbessern will, dann kann man nicht kommen und sagen aber dieses Mittel der relativen Mehrheitswahlrechts das ist gegen den Staat überhaupt gerichtet. davon kann doch gar keine Rede sein... (COA18)

COMP+:(ja) (schön)... aber... - evite discordância: concorde simbolicamente; ...und sagen aber dieses Mittel....gerichtet - intensifique o interesse: aproxime o interlocutor

COMP-: bis jetzt hat es bei uns auch funktioniert - relativize a própria opinião; man kann nicht sagen - impersonalize: gerencie a dêixis pessoal; davon kann ...keine Rede sein - invoque regras gerais

(PROP/T) (es hat mehr schlecht als recht funktioniert) (COA19)

$\mathrm{COMP}+$ : graceje

(PROP/T) [FDP traut sich nicht, einige Abgeordnete in direkten Wahlen durchbringen, wie die Liberalen in England] sehen sie (Herr Heizler) das ist ja eben der Unterschied zu anderen Ländern. wir haben ja nicht diese Einheitlichkeit bei uns [...] zweitens [...] man kann doch nicht den Wählern noch zumuten, weil sie einen liberalen Mann haben, müssen alle in einen Wahlkreis ziehen, damit sie ihn dort wählen können... (COA20)

COMP+: sehen sie - intensifique o interesse: aproxime o interlocutor; das ist ja eben... wir haben ja nicht... - crie/pressuponha pontos comuns; Unterschied ... zweitens... wählen können - dê (ou peça) razões

OFF/aux: man kann doch nicht ... müssen alle... in einen Wallkreis ziehen - exagere

(PROP/T) [Strauß hat gesagt, daß sich jeder Mensch irren kann] das stimmt. jeder Mensch kann sich irren im politischen Bereich im sachlichen Bereich. ich habe auch mehr gesagt. ich habe gesagt, wer von mir behauptet, ich hätte gelogen (daß heißt) in Kenntnis der Wahrheit die Unwahrheit gesagt, der lügt selber... (COA21)

OFF: wer von mir behauptet... der lügt selbst - dê pistas para associações: - se o interlocutor tinha essa idéia aos propor o tema, o mesmo vale para ele.

$\mathrm{COMP}+$ : das stimmt. jeder Mensch kann sich irren... ich habe auch mehr gesagt - evite discordância: relativize a opinião do interlocutor. 
(PROP/P) [Herr Schmidt wolle etwas ergänzend sagen] ich ...ahn... (nein) ich wollte Herrn Strauß eine Frage stellen... (COA22)

DIR: nein + informação correta

(PROP/T) [Frage an Strauß: jeder Mensch kann sich irren in der 3. Person; gilt es auch für ihn selbst?] die beiden ...ahn... gegen mich erhobene Vorwürfe [...] sind objektiv falsch. ich habe in 2 Punkten mich geirrt [...] und habe das dann später schriftlich gegenüber dem Bundestag korrigiert... (COA23)

COMP+: die beiden Vorwürfe... sind objektiv falsch - evite discordância: relativize a opinião do interlocutor (aqui a concordência é evitada, por ser prejudicial ao falante, então, relativiza-se a concordância - um caso de "aber, ja..."); ich habe ... mich geirrt...gegenüber dem Bundestag korrigiert - dê (ou peça) razões

(INT) das ist ne halbe Antwort (Herr Strauß) können sie nicht die volle Antwort geben? (COA24)

COMP+: das ist ne halbe Antwort - dê (ou peça) razões; können sie nicht...geben? crie/pressuponha pontos comuns

(INT) jetzt ...ahn... (Herr Schmidt) ...ahn... versetzen sie sich in die Situation der Journalisten [...] es tut mir leid, daß ich hier abbrechen muß, und ich komme hoffentlich nicht in den Verdacht, daß ich jetzt ein Thema abbrechen will, aber ich werde ja ständig von den Herren der Kamera gedrängt... (COA25)

COMP+: jetzt ... in die Situation der Journalisten; ich werde... gedrängt - dê (ou peça) razões; ich komme hoffentlich nicht in den Verdacht... - seja otimista (interessante a dissenção de uma possibilidade de interpretação do interlocutor); ich werde ja... crie/pressuponha pontos comuns

COMP-: es tut mir leid - peça desculpas; abbrechen muß - indique relutância

(INT) es stand hier im Bundestag nicht ... das: stand hier nicht zur Debatte (Herr Gerstenmaier) (COA26)

COMP+: das: stand hier nicht zur Debatte - dê (ou peça) razões

OFF/aux: das: - dê pistas para associações - entonação marca um ponto polêmico e quebra das regras.

(INT) wollen wir da jetzt nicht einen Strich drunter machen? (COA27)

COMP+: wollen wir nicht...? - crie/pressuponha pontos comuns

COMP-: wollen wir...? - forma de convite, einen Strich drunter machen - utilize formas convencionalizadas

(PROP/T) [in der Großen-Koalition] in der großen oder in einer kleinen oder wo auch immer. Jeder Mensch hat das nicht nur unter Politikern. (COA28)

COMP+: in der großen...wo auch immer - evite discordância: relativize a opinião do interlocutor

COMP-: jeder Mensch hat das... - invoque regras gerais 
(PROP/T) [...] und unglückliche Verhaltensweise oder falsche Reaktionen, die auch den Irrtum mit einschließt, ist etwas ganz anderes als das, was mir wirklich vorgeworfen worden ist. (COA29)

OFF: ist etwas ganz anderes...vorgeworfen worden ist - seja vago

COMP-: Verhaltensweise, Reaktion, Irrtum - defocalize os participantes

(PROP/T) ich glaube nicht ich glaube nicht (Herr Gerstenmaier) daß das eine Interpretation ist, die von allen 500 Mitgliedern des Hauses so geteilt würde. ich glaube, da müssen sie etwas vorsichtiger formulieren. ich über rede nicht über meine eigene Auffassung, sondern ich meine, sie sollten bei der Interpretation dieses Vorgangs etwas zurückhaltender sein. (COA30)

DIR: nicht

COMP-: ich glaube, etwas, ich meine - relativize a própria opinião; ...geteilt würde; sie sollten... - gerencie o grau de realidade; ich rede nicht über meine eigene Auffassung - apele à autoridade/objetividade

OFF/aux: von allen 500 Mitgliedern... - exagere

(PROP/T) ich kann nur sagen, das ist der praktische und auch nach meiner Überzeugung grundsätzliche Effekt dessen... (COA31)

COMP-: ich kann nur sagen - indique relutância; nach meiner Überzeugung, praktisch, grundsächlich - relativize a própria opinião

(INT) [Frage "Strauß" zur Koalisionsfrage machen] wir haben sie (Augenblick) wir haben sie nicht zur Koalisionsfrage gemacht, wie sie wissen... (COA32)

DIR: nicht

COMP+: wie sie wissen - crie/pressuponha pontos comuns

(PROP/T) aber der Präsident des Hauses muß bei der Interpretation des Willens der Mitglieder dieses Hauses sich zurückhalten. sie können als Abgeordneter der CDU ihre persönliche Interpretation nach ihrem Urteil und ihrem Willen aussprechen. (COA33)

DIR: aber

COMP+: sie können als Abgeordneter... ihrem Wille aussprechen - busque concordância: relativize a própria opinião

COMP-: der Präsident...muß sich zurückhalten - invoque regras gerais

(INT) (Verzeihung) (Herr Schmidt) jetzt tun sie mir Unrecht. ich: habe hier den Präsidenten des Bundestages gebeten, ein Schlußwort zu reden. er hat es so gehalten, wie er: es eben für richtig hält. ich würde da doch den Respekt (COA34)

DIR: Unrecht

COMP+: jetzt... Unrecht. ich:... für richtig hält - dê (ou peça) razões

COMP-: (Verzeihung) - peça desculpas; ich würde da doch den Respekt - o falante coloca-se no lugar do interlocutor - defocalize os participantes 
(PROP/T) wenn ich was sagen darf (Herr Appel) außerdem ist ein Unterschied von der ...ahn... zwischen der Erklärung, die der Präsident im Amt vor dem Hause abgibt, und dem, was er im Rahmen einer freien allerdings öffentlichen Diskussion sagt... (COA35)

DIR: Unterschied

COMP+: wenn ich was sagen darf - seja otimista; außerdem ist ein Unterschied...

Diskussion sagt - dê (ou peça) razões 


\section{Inquérito: EXTERIOR; Duração: 25'10"; Participantes: 5 (homens); Ocorrências de} Dissensão: 13

(PROP/T) aber da... ich muß da noch eine Gegenfrage stellen. sie sagen die Schlagkraft ...ahn... der auswärtigen Kulturpolitik sie wurde doch bisher dauernd dadurch gerade gelähmt, weil im Auswärtigen-Amt ...ahn... die Geschichte eigentlich dann immer kameralistisch behandelt worden is [...] das is nicht Verstärkung der Schlagkraft. das ist Verminderung der Schlagkraft. (EXT1)

DIR :nicht...+ opposite statement

COMP-: ich muß eine Gegenfrage stellen - indique relutância - apesar da formulação, não há pergunta.

(PROP/T) wir planen gar nicht nebeneinander her (EXT2)

DIR: gar nicht

(PROP/T) (o ja) Inter Nationes das Goethehaus und die ...ahn... DAAD die planen wahn:sinnig nebeneinander her. das sieht man dauernd in der Praxis. (EXT3)

DIR: (o ja)

$\mathrm{COMP}+$ : exemplo contrários - dê (ou peça) razões; wahnsinnig, dauernd - intensifique o interesse: aproxime o interlocutor

(PROP/T) [muß das eine Entscheidung des Auswärtigen-Amtes sein?] (ja) das ist das Ergebnis ...ahn... doch unserer Planungsuntersuchungen (nich?) [...] ich glaube, daß irgendwo eine zentrale Arbeitsstab is, der in engster Zusammenarbeit mit diesen Organisationen darüber befindet. darüber dürfte eigentlich kein Zweifel bestehen. (EXT4)

DIR: doch

$\mathrm{COMP}+$ : Ergebnis unserer Planungsuntersuchungen - inclua falante e interlocutor na atividade: gerencie a dêixis pessoal; nich?, dürfte kein Zweifel bestehen crie/pressuponha pontos comuns

COMP-: ich glaube, eigentlich - relativize a própria opinião

(PROP/T) darüber ist kein Zweifel, aber der zentrale Arbeitsstab der sollte sich wahrscheinlich doch so: miteinander zusammenschließen, daß er tatsächlich mit diesen einzelnen im Ausland arbeitenden Leuten etwas zu tun hat und, daß er nicht ...ahn... hauptsächlich vom ...ahn... von dem Beamtensystem im Auswärtigen-Amt vorbestimmt ist. (EXT5)

DIR: doch

COMP+: darüber ist kein Zweifel, aber - evite discordância: concorde simbolicamente;

COMP-: wahrscheinlich, hauptsächlich - relativize a própria opinião; der sollte sich... - gerencie o grau de realidade

OFF/aux: - dê pistas para associações - entonação em so: contrasta com o modo como acontece realmente. 
(PROP/T) wir haben jetzt wir haben jetzt grade in London eine eine Regionalkonferenz gehabt [...] alle diejenigen, die nun einerseits in Großbritannien für die praktische Arbeit ...ahn... verantwortlich sind und dann diejenigen, die die Richtlinien bestimmen [...] (EXT6)

COMP+: exemplo contrário - dê (ou peça) razões

(PROP/T) aber zum ersten mal... (das ist doch was völlig Neues) (EXT7)

DIR: aber, doch + argumento contrários.

COMP+: zum ersten mal, was völlig Neues - dê (ou peça) razões

(INT) ich würde vorschlagen doch in dieser Frage noch etwas zu warten. Wir sind ja gerade dabei, diesen Planungsapparat aufzubauen... (EXT8)

DIR: doch

COMP-: ich würde vorschlagen... - gerencie o grau de realidade; wir sind dabei .... aufzubauen - dê (ou peça) razões; ja - crie/pressuponha pontos comuns

(PROP/T) [schwerfälligen Apparat schaffen] (ja) schwerfällig soll er nich sein (EXT9)

DIR: $n i c h$

COMP-: soll ... sein - afastamento epistêmico: utilize verbos modais

(PROP/T) ich habe meine Erfahrung mit dieser Art der Apparate. (EXT10)

OFF: dê pistas para associações - o falante considera os aparatos estatais complicados; diante da discordância do interlocutor, replica que tem experiências próprias nesses casos - implicação: sua experiência mostra que tais aparatos são sempre difíceis, logo, aquele que o interlocutor propõe também o será.

(PROP/T) aber ich glaube schwerfälliger als der bisherige könnte es gar nicht werden schwerfälliger als der bisherige... (EXT11)

DIR: aber, gar nicht

COMP-: ich glaube - relativize a própria opinião; ...könnte es gar nicht werden gerencie o grau de realidade

(EXTM) (ja) ...ahn... präzisieren würde ich nicht sagen. ich würde sagen ich würde den die Aufgabenstellung etwas definieren... (EXT12)

DIR: nicht

COMP-: würde ich... sagen- gerencie o grau de realidade

(PROP/T) ...Punkte noch hinzu meiner Meinung nach. bitte um Entschuldigung (Herr Höllerer) und ... ahn... der eine is eben, daß es eine Begegnungsstätte für die

Ausstrahlungen beider Länder wird... (EXT13)

$\mathrm{COMP}+$ : eben -crie/pressuponha pontos comuns

COMP-: meiner Meinung nach - relativize a própria opinião; bitte um Entschuldigung

- peça desculpas 


\section{Inquérito: GuERRA; Duração: aprox. 30"; Participantes 3 (homens); Ocorrências de Dissenção: 74}

(PROP/T) [es handelt sich um Herrn Pleiderer und zwar Springer-Informanten] (nein) das stimmt leider nicht (nein) (GUE1)

DIR: nein, stimmt nicht

COMP-: leider - peça desculpas

(EXTM/Strat) [sie müssen das abstreiten] (nein) nicht wir mü:ssen sondern (nein) (GUE2)

DIR: nein, nicht... sondern

(PROP/T) [wir haben sie ja bisher fair behandelt] sie haben mich fair behandelt? sie haben mich verleumdet (Herr Löwenthel) (GUE3)

OFF: sie haben mich fair behandelt? - repetição + entonação - dê pistas para associações - implicação: não concordância;

DIR: sie haben mich verleumdet - afirmação contrária, utilizando o antônimo do conceito usado pelo interlocutor (fair behandeln-verleumden)

(PROP/P) [nachdem er mit uns in Bevilaqua war] (nein) vorher (GUE4)

DIR: nein + informação correta

(INT) aber ...ahn... aber (nein) (Herr Nannen) nun drehen sie doch die Dinge nicht um... (GUE5)

DIR: nein, aber, doch nicht

(PROP/T) [die eidesstattliche Erklärung] das ist doch gar nicht drin... (GUE6)

DIR: doch gar nicht

(INT) [lassen sie mich doch ausreden] (Herr Nannen) sie dürfen aber nicht die Unwahrheit sagen (GUE7)

DIR: aber

COMP-: dürfen nicht die Unwahrheit sagen - invoque regras gerais

(PROP/T) sie haben 30 Minuten geredet. nun lassen sie mich doch mal ausreden... (GUE8)

DIR: doch

COMP+: dê (ou peça) razões

(PROP/T) [nun lassen sie mal die Geschichte weiter erzählen] Ihre Version (GUE9)

OFF: dê pistas para associações: o falante afirma que é a versão do interlocutor, o que é óbvio - implicação: a versão do interlocutor e a do falante não coincidem. 
(PROP/T) [Ihre Version] (nein) (nein) eine durch Dokumente zu beweisende Version (GUE10)

DIR: nein

COMP-: durch Dokumente zu beweisend - apele à autoridade/objetividade

(PROP/T) [warum lassen wir denn nicht die Gerichte darüber urteilen?] aber, weil unsere Zuschauer ein Recht darauf haben heute und hier zu erfahren, was los ist und es nicht erst auf die Gerichte zu... (GUE11)

COMP+: weil... - dê (ou peça) razões, desmontando a convencionalidade da pergunta retórica anterior e atraindo a simpatia do público.

(PROP/T) [das haben sie heute morgen in Bonn bestritten] das hab ich nicht: bestritten... (GUE12)

DIR: nicht

(PROP/T) (nein) sie haben aber gesagt ...ahn... wir ...ahn... Herr Kindler wäre auf eigene Kosten nach Bevilaqua gereist. dieses stimmt leider nicht. (GUE13)

DIR: stimmt nicht

COMP+: nein, aber... - evite discordância:concorde simbolicamente

COMP-: leider - peça desculpas

(PROP/T) [das entspricht ihrer Mentalität, daß sie alle immer für dumm halten] (nein) sie halten ihre Zuschauer für dumm (Herr Löwenthel)... (GUE14)

DIR: nein

(PROP/T) [...] (nein) das haben wir noch nie getan (GUE15)

DIR: nein, nie

(PROP/T) [nichts haben sie geprüft] (aber jetzt halten sie unsere Zuschauer für dumm) (sie haben doch eben gesagt wir waren mit Herrn Kindler in Bevilaqua) (wie können sie denn behaupten wir hätten nichts geprüft? (das geht doch gar nich). (GUE16)

OFF: jetzt halten Sie... dumm - retomada das palavras do interlocutor - dê pistas para associações - o interlocutor toma os espectadores por idiotas - implicação: ele os está enganando / o que ele diz não é verdade.

DIR: aber, doch, das geht nicht

COMP+: sie haben doch gesagt...Bevilaqua - dê (ou peça) razões

OFF/aux: wie können sie...nichts geprüft? - use perguntas retóricas

(PROP/T) [machen sie die Hinterhand auf die ist nämlich leer] die ist gar nicht so leer. (GUE17)

COMP+: nicht so leer - evite discordância: relativize a opinião do interlocutor 
(PROP/P) [...] auch da haben sie sehr unvollständig recherchiert. es ist nämlich nich nur ein: Junge umgekommen, sondern es sind umgekommen vier: Personen [...] (GUE18)

DIR: nicht... sondern

COMP+: es ist nämlich... - dê (ou peça) razões

COMP-: da haben sie ... recherchiert - minimize a imposição

(PROP/P) (aber nicht aufgehängt) (Herr Nannen) (GUE19)

DIR: aber, nicht

(PROP/T) [was sie betreiben ist gemeingefährlich] (nein) (Herr Nannen) was sie betreiben ist gemeingefährlich, denn... (GUE20)

DIR: nein

COMP+: denn... - dê (ou peça) razões

(PROP/T) [ohne es beweisen zu können?] ... die Zuschauer verstehen sehr gut wer glaubwürdig ist und wer nicht... (GUE21)

OFF: seja vago

(INT) [es sind umgekommen...] das haben wir gar nicht bestritten (Herr Nannen) (GUE22)

DIR: gar nicht

(INT) [nun kann ich ihnen dazu weiter sagen...] sagen sie es doch dem Richter (Herr Nannen) tun sie mir doch einen Gefallen (GUE23)

OFF: sagen sie es doch dem Richter - dê pistas para associações - só se diz algo ao juiz quando se está sendo julgado - implicação: o falante vai processar o interlocutor e não quer discutir o assunto agora; tun sie mir doch einen Gefallen - seja irônico - o falante é exageradamente gentil frente à situação.

(PROP/T) ...ahn... (nein nein) den Zuschauern den Zuschauern (GUE24)

DIR: nein

(PROP/T) (ja) aber die können ja überhaupt nicht beurteilen, woraus sie hier zitieren... (GUE25)

COMP+: (ja aber) - evite discordância: concorde simbolicamente; die können... - dê (ou peça) razões; $j a$ - crie/pressuponha pontos comuns

(INT) es geht hier um den Vorwurf der Manipulation und nicht um die Nennung von neuen Zeugen für neue Tatsachen (GUE26)

COMP+: dê (ou peça) razões

(PROP/P) es geht nicht um neue Tatsachen. es geht um alte Tatsachen (GUE27)

DIR: nicht

(PROP/T) [sie verlieren die Nerven (Herr Nannen) bleiben sie ruhig] aber meine Nerven sind ganz ausgezeichnet (Herr Löwenthel) (GUE28) 
DIR: aber

OFF/aux: ausgezeichnet - exagere

(PROP/T) [Nannen behauptet, der Friseur habe sich beklagt, das Fernsehteam hätte ihn nicht ausreden lassen] (Herr Nannen) erstens liegt dem ZDF ein in Bild und Ton ein Interview mit dem von ihnen zitierten Friseur vor, in dem der Friseur auf meine Frage, ob ich ihm etwas in dem Mund gelegt habe er etwas verschwiegen hat oder er mehr sagen wollte, als wir aufgenommen haben, in allen Teilen bestätigt, das dies nicht: der Fall ist... (GUE29)

DIR: nicht der Fall

COMP+: erstens... bestätigt - dê (ou peça) razões - o fato de apresentar as razões antes da Dissensão dá a esta maior peso; ein in Bild und Ton ein Interview - apele à autoridade/objetividade

(INT) (ja) das hat doch nichts mit unserem Fall zu tun (Herr Nannen)... (GUE30)

DIR: doch, hat nichts zu tun

(PROP/T) [sie waren Widerstandskämpfer (ironisch)] ich war kein Widerstandskämpfer. mich wollten die Nazis nicht haben da (Herr Löwenthel) ich habe nie gesagt, daß ich ein Widerstandskämpfer war. (GUE31)

DIR: kein; nie

$\mathrm{COMP}+$ : mich...nicht haben - dê (ou peça) razões

(INT) (nein) (Herr Herr Nannen) jetzt kommen wir über den Punkt... (GUE32)

DIR: nein

COMP+: dê (ou peça) razões

(PROP/T) [wir können über Weidmann eine zweite Sendung machen] (nein) (GUE33)

DIR: nein

(PROP/T) [...aber hier und heute muß vom Tisch, daß der Weidemann ein

Kriegsverbrechen begangen hat] (das kommt ja nicht vom Tisch) (Herr Nannen)

(GUE34)

DIR: nicht

COMP+: ja - crie/pressuponha pontos comuns

(PROP/T) [und daß wir daß ich daran beteiligt gewesen bin] das haben wir nicht gesagt (GUE35)

DIR: nicht

(PROP/T) [und daß wir daß ich daran beteiligt gewesen bin] (ja) aber wir haben das ja nie behauptet (GUE36)

DIR: aber, nie

$\mathrm{COMP}+: j a-$ crie/pressuponha pontos comuns

(PROP/T) [Vorwurf der Manipulation] ... wir haben unsere Dokumente. wir können nachweisen, das wir journalistisch vö:llig einwandfrei gearbeitet haben. (GUE37)

$\mathrm{COMP}+$ : dê (ou peça) razões

COMP-: Dokumente, journalistisch - apele à autoridade/objetividade 
(PROP/T) (Herr Löwenthel) warum klagen sie dann nicht gegen meinen Vorwurf, daß sie manipuliert hätten... (GUE38)

COMP+: dê (ou peça) razões

(PROP/T) (nein) das haben wir ja nicht nötig. (GUE39)

DIR: nein

COMP+: dê (ou peça) razões; $j a$ - crie/pressuponha pontos comuns

(PROP/T) [Weidemann war 3 Monate stellvertretender Gauleiter] (nein) er war viel mehr (Herr) verniedlichen sie doch die Dinge nicht (Herr Nannen) (GUE40)

DIR: nein

OFF/aux: viel mehr, verniedlichen... nicht - dê pistas para associações - o interlocutor não estaria dizendo toda a verdade / estaria escondendo algo.

(PROP/T) [Halten sie diesen Mann für geeignet, heute die deutsche Jugend in einem demokratischen Staat in dieser BR zu erziehen?] (nein) das tut er auch gar nicht, sondern er ist ein reiner Organisator. (GUE41)

DIR: nein, gar nicht... sondern

(PROP/T) Er hält Reden. (GUE42)

OFF: dê pistas para associações - Weidemann faz palestras, organizadores não fazem palestras - implicação: o interlocutor não está sendo correto.

(INT) [Nannen will Teile eines Briefes zitieren] (aber aber zitieren sie doch bitte nich Herrn Speer (GUE43)

DIR: aber, doch, nicht

COMP-: bitte - dê deferência - devido à deterioração da relação entre os participantes, tem um leve efeito irônico.

(PROP/T) [Nannen zitiert trotzdem] aus dem Jahre 1933 (Herr Nannen) (GUE44) OFF: dê pistas para associações - a carta é de antes do início da guerra - implicação: não diz respeito ao tema da discussão. 
(PROP/T) aus dem Jahre 1949. hier ist es. (GUE45)

DIR: proposição contrária

(PROP/T) (ja) aber das bezieht sich wollen sie bitte ganz zitieren. bleiben sie ehrlich. da steht drin 33, 34, in die:sem Jahr:. ich habs genau gelesen, was Herr Nolde geschrieben hat. (GUE46)

COMP+: ja, aber... evite discordância: concorde simbolicamente

COMP-: wollen sie... - utilize formas convencionalizadas; bitte - dê deferência

OFF/aux.: wollen sie bitte ganz zitieren, bleiben sie ehrlich - dê pistas para

associações - o interlocutor não cita tudo, deve permanecer honesto - implicação: ele não está sendo honesto..

(PROP/T) [Weidemann habe die Zeitungen zensiert] (ach) woher wollen sie das wissen? (GUE47)

OFF: use perguntas retóricas

(INT) [Löwenthel möchte etwas vorlesen] ich weiß nicht, wo sie ihre Dokumente her haben. (GUE48)

OFF: dê pistas para associações - só é importante conhecer as fontes dos documentos quando há dúvida sobre eles - implicação: o falante não aceita os documentos.

(PROP/T) (ja sicher) aus guter Stelle haben wir sie. sie sind alle echt (Herr Nannen) (GUE49)

DIR: proposição contrária, respondendo à Dissensão implícita em GUE48.

(PROP/T) [Weidemann habe versucht zu retten, was zu retten war] dann gehe ich doch nicht freiwillig in den SD (Herr Nannen) das ist doch nich möglich so etwas. (GUE50)

DIR: doch, nicht möglich

$\mathrm{COMP}+$ : dann gehe...in den $S D$ - dê (ou peça) razões

(PROP/T) (eine Sekunde) das bestreite ich. das bestreite ich einfach. das müssen sie mir erst einmal beweisen. (GUE51)

DIR: bestreite

$\mathrm{COMP}+$ dê (ou peça) razões

(PROP/T) das Dokument liegt vor. das Dokument liegt vor (Herr Nannen) (GUE52)

COMP-: Dokument - - apele à autoridade/objetividade

(PROP/T) (ja) (ja) Dokumente kann man viele machen. (GUE53)

OFF: dê pistas para associações - pode-se fazer muitos documentos, podem ser forjados - implicação: o falante não aceita os documentos do interlocutor.

(PROP/T) [Weidemann habe Nannen das Leben gerettet] (das stimmt leider auch nicht) (Herr Nannen) (GUE54)

DIR: stimmt nicht

COMP-: leider - peça desculpas 
(PROP/T) [ein Mann mit so einer Vergangenheit verantwortlich für die Jugend] ich würde ihn nie zum Redakteur machen. er hat keinerlei meinungsbildende Tätigkeit im Stern. er hat keinerlei meinungsbildende Tätigkeit im Stern. er ist ein Organisator. (GUE55)

COMP+: dê (ou peça) razões

(PROP/T) [ach Herr Löwenthel dieses Mätzchen müssen sie jetzt machen] (nein) (nein) das ist kein Mätzchen (GUE56)

DIR: nein, kein

(PROP/T) ich muß: überhaupt nicht wollen sie das mal zur Kenntnis nehmen. (GUE57)

DIR: nicht

COMP-: wollen sie ... mal... - utilize formas convencionalizadas - has an aggressive effect due to the deterioration of the relationship.

(PROP/T) Dokumente aus dem Osten? (GUE58)

OFF: dê pistas para associações - entonação - no período da guerra fria, documentos da Alemanha Oriental não eram considerados confiáveis - implicação: o falante não aceita o documento sugerido pelo interlocutor como válido.

(PROP/T) [es gibt keinen Fall im Stern] aber (Herr Nannen) wir können doch die Nummer vom Stern hier zitieren. (GUE59)

DIR: aber, doch

COMP-: die Nummer zitieren - apele à autoridade/objetividade

(PROP/T) es gibt keinen Fall im Stern, in dem ich jemanden seine nationalsozialistische Vergangenheit vorgeworfen hätte, es sei denn, er ist schuldig geworden. (GUE60)

DIR: keinen

COMP-: es sei denn - relativize a própria opinião - deixando uma saída para própria Face.

(PROP/T) [und da stellen sie fest, wer schuldig geworden ist] (nein) (das brauch ich nich festzustellen) (GUE61)

DIR: nein

COMP+: das brauche ich... - dê (ou peça) razões

(PROP/T) [Ihre Berichte im Völkischen Beobachter] (es hat nie ein Bericht von mir im Völkischen Beobachter gestanden) (GUE62)

DIR: nie

(PROP/T) sechsten Juli 1941 (Herr Nannen) (GUE63)

OFF: dê pistas para associações - nesta data deve haver algo relacionado à contribuição do interlocutor; ele dizia que não havia relatórios em um jornal implicação: há um relatório dele neste jornal / nesta data / o interlocutor não está dizendo a verdade. 
(PROP/T) [er habe natürlich Kriegsberichte geschrieben] am 6. Juli 1941. wir reden nicht von Jubelberichten. wir reden nicht von Kriegsberichten. [...] bei der Waffen-SS war das etwas anderes... (GUE64)

DIR: nicht; etwas anderes

(PROP/T) [Weidemann nicht bei der Bandenbekampfung gewesen] aber es steht doch hier drin. (GUE65)

DIR: aber, doch

COMP-: es steht hier drin - apele à autoridade/objetividade

(PROP/T) sie haben das Unternehmen Wintermärchen haben sie ein berüchtigtes Bandenbekämpfungsunternehmen genannt (Herr Löwenthel) sie sind falsch orientiert. (GUE66)

COMP-: sie sind falsch orientiert - minimize a imposição

(PROP/T) (nein) das haben wir nicht getan. wir haben gesagt er war beim Chef der Banden...ahn... Kampfverbände. (GUE67)

DIR: nein, nicht + informação correta

(PROP/T) (doch:) (GUE68)

DIR: doch

(PROP/T) er war nie beim Chef der Bandenkampfverbände. (GUE69)

DIR: nie

(PROP/T) (doch) (GUE70)

DIR: doch

(PROP/T) wissen sie, was Wintermärchen war? das war ein Propagandaunternehmen [...] so verfälschen sie Nachrichten. (GUE71)

DIR: verfälschen

OFF/aux: wissen sie, was Wintermärchen war? - use perguntas retóricas

(INT) (Herr Herr Herr Nannen) das laß ich mir nicht gefallen. wir haben hier ein Original eine Fotokopie... (GUE72)

COMP-: das laß ich mir nicht gefallen - utilize formas convencionalizadas; Original, Fotokopie - apele à autoridade/objetividade

(INT) sie ziehen da was zusammen, was nicht zusammengehört [...] sie verwechseln Kampfauftrag mit Kampfpropagandaauftrag. (GUE73)

$\mathrm{COMP}+$ : dê (ou peça) razões

(PROP/T) (nein) (nein) (nein) (nein) (nein) (nein) (nein) ...ahn... sie können mich natürlich leicht über militärische Ausdrücke belehren wollen...(GUE74)

DIR: nein 
Inquérito: MÃES; Duração: 31'50"; Participantes: 9 (mulheres); Ocorrências de Dissensão: 43

(PROP/T) [Kinder, die das Haus verlassen, fühlen sich bestraft] (nun) man ...ahn... man man kann nicht als Tochter aus dem Haus gehen und sagen denen zeige ich s jetzt (ne?) sondern man muß ...ahn... man läßt hinter sich ein bißchen ein Trümmerfeld zurück. man bricht: mit zu Hause. (MAE1)

DIR: nun; nicht...sondern

COMP+: man kann nicht... sondern man muß... - dê (ou peça) razões; denen zeige ich $s$ jetzt - intensifique o interesse: aproxime o interlocutor; $n e$ ? - crie/pressuponha pontos comuns;

COMP-: man kann nicht... - invoque regras gerais; ein bißchen - relativize a própria opinião

(PROP/T) (ja) das dürfte die Strafe für die Eltern sein. aber die Strafe für die Töchter ist eben dann [...] daß sie eben selbst zurechtkommen müssen... (MAE2)

COMP+: (ja) das dürfte... sein, aber... - evite discordância: concorde simbolicamente; eben - crie/pressuponha pontos comuns

(PROP/T) ich meine also, daß das auf keinen Fall ne Strafe ist. ich bin ja von zu Hause abgehauen und ...ahn... ich habe so wahnsinnig viel gelernt in der Zeit [...] ich bin also viel selbstsicherer, als als ich zu Hause jemals war... (MAE3)

DIR: auf keinen Fall

COMP+: ja, also - crie/pressuponha pontos comuns; ich bin von zu Hause

aubgehauen... viel gelernt in der Zeit - exemplo contrário - dê (ou peça) razões; so wahnsinnig viel - intensifique o interesse: aproxime o interlocutor COMP-: ich meine - relativize a própria opinião

$(\mathrm{PROP} / \mathrm{T})$... und ich finde es ist gar nicht Voraussetzung, daß einem die Eltern im Rücken liegen müssen. also ich fand, daß meine Eltern mich ...ahn... /zum

Selbstbewußtsein hinführen können, und da bin ich froh darüber (MAE4)

DIR: gar nicht

COMP+: meine Eltern .... - exemplo contrário - dê (ou peça) razões

COMP-: ich finde - relativize a própria opinião

(PROP/T) (ja) sie haben aber noch immer ... ahn... trotzdem immer noch das Gefühl (ja) wenn ich mich mal verhaue, dann sind aber die Eltern wieder da [...] wenn man allein ist, dann ist man aber viel mehr auf sich gestellt. dann kann man viel mehr lernen, als wenn man immer noch im Unbewußtsein immer noch denken kann (na ja) also meine Eltern die können mich ja dann immer noch zurückreißen in dem Fall. (MAE5)

COMP+: (ja) sie haben aber... - evite discordância: concorde simbolicamente; sie haben immer... - o falante atribui sentimentos ao interlocutor - - crie/pressuponha pontos comuns; wenn ich mich mal verhaue... wieder da, (na ja) also ... in dem Fall intensifique o interesse: aproxime o interlocutor;

COMP-: man kann viel mehr lernen... - invoque regras gerais

(PROP/T) (ja) ich meine es ist ich find es $n$ bißchen plötzlich, wenn man also von zu Hause wegrennt und dann plötzlich ...ahn... das ist aber doch gar nicht nötig. (MAE6) 
DIR: aber, doch, gar nicht

COMP-: ich meine, ich find, ein bißchen - relativize a própria opinião; plötzlich minimize a imposição

OFF/aux: und dann plötzlich... - seja incompleto

(INT) (nun ja) (nun ja) lassen wir das... (MAE7)

DIR: (nun ja)

$\mathrm{COMP}+$ : lassen wir das... - inclua falante e interlocutor na atividade: gerencie a dêixis pessoal

(PROP/T) [ihre Tochter empfindet sie als schwierig] (nein) (nein) eigentlich nicht. sie kommt immer mit ihren Angelegenheiten... (MAE8)

DIR: nein, nicht

$\mathrm{COMP}+$ : sie kommt immer... - dê (ou peça) razões

COMP-: eigentlich - relativize a própria opinião

(PROP/T) wie ich das so sehe, ist hier die Selbständigkeit kein Erziehungsproblem sondern einfach nur ein Charakterproblem ihrer Tochter [...] ich glaube es ist schwierig einen unselbständigen Menschen zum Selbständigwerden zu führen [...] solange er zu Hause ist, geht das dann nur, wenn er selbst diesen Charakter hat und selbständig sein will. (MAE9)

DIR: kein... sondern

COMP+: Charakterproblem ... es ist schwierig... solange er zu Hause ist... - dê (ou peça) razões

COMP-: wie ich das so sehe, ich glaube - relativize a própria opinião

(PROP/T) (ja) das liegt aber doch nicht im Charakter er ist unselbständig oder selbständig. das ist doch durch die Erziehung geprägt schon von ganz klein auf (MAE10)

DIR: doch

COMP+: (ja) das liegt aber doch nicht... - evite discordância: concorde simbolicamente

(PROP/T) (nein) das glaub ich nicht. (MAE11)

DIR: nein, nicht

COMP-: ich glaub - relativize a própria opinião

(EXTM) [sie sind praktisch auf der Straße aufgeklärt worden] auf der Straße ist der falsche Ausdruck sondern von Freunden und Bekannten... (MAE12)

DIR: falscher Ausdruck; sondern + informação correta

(INT) das war aber nicht der Kern meiner Frage. ich wollte wissen... (MAE13)

DIR: aber, nicht

COMP+: das war... meiner Frage - dê (ou peça) razões

COMP-: ich wollte wissen... - ela ainda quer saber a mesma coisa- afastamento temporal: gerencie a dêixis temporal

$(\mathrm{PROP} / \mathrm{T})$ [ich würde nicht heiraten] sie auch nicht? ...ahn... das ist leicht gesagt. wir werden vielleicht in 20 Jahren noch einmal ein Podium machen... (MAE14) 
OFF: sie auch nicht? - dê pistas para associações: repetição + entonação - implicação: o falante não acredita nisso; ... vielleicht in 20 Jahren noch einmal ein Podium machen... - seja incompleto

COMP-: das ist leicht gesagt - utilize formas convencionalizadas

(PROP/T) [Egoismus als Probleme in einer Kommune] ich finde den den Egoismus braucht man in einer Kommune nicht auszuschließen... (MAE15)

DIR: nicht

COMP-: ich finde - relativize a própria opinião; man - impersonalize: gerencie a dêixis pessoal

$(\mathrm{PROP} / \mathrm{T}) \ldots$ daß hier $n$...ahn... falsches Bild von ner Kommune gezeichnet wird, denn, wenn die Leute ne Kommune aufmachen wollen, dann tun se das ...ahn... (wenigstens nach meiner Erfahrungen) nicht hauptsächlich um ...ahn... der freien Liebe zu frönen, sondern um zusammen zu arbeiten. (MAE16)

DIR: falsches Bild

COMP+: denn... - dê (ou peça) razões;

COMP-: falsches Bild...gezeichnet wird - impersonalize: gerencie a dêixis pessoal; wenigstens, nach meiner Erfahrung, hauptsächlich - relativize a própria opinião

(PROP/T) [Leben in Wohngemeinschaft gar nicht wie in Illustrierten] aber das wird es auch geben. denn es gibt ja durchaus Kommunen verschiedener Art. (MAE17)

DIR: aber

COMP+: es... auch geben - evite discordância: relativize a opinião do interlocutor; denn... - dê (ou peça) razões

COMP-: es wird geben - gerencie o grau de realidade

(PROP/T) würden sie aber praktisch die Entscheidung erst dann fällen, wenn ...ahn... sie die Gegebenheiten gefunden haben und nicht akzeptieren? sie müssen ja von vornherein klar sein darüber, will: ich in einer Kommune leben oder will ich nicht in einer Kommune leben. (MAE18)

DIR: aber

COMP+: sie müssen ja... - crie/pressuponha pontos comuns; will: ich... in einer

Kommune leben - intensifique o interesse: aproxime o interlocutor

COMP-: würden sie... nicht akzeptieren? - evite afirmações: faça perguntas; praktisch relativize a própria opinião; sie müssen...klar sein darüber... - invoque regras gerais

(PROP/T) [es ist ihre Natur, nicht in einer Kommune zu leben] ich bezweifle, daß das Natur ist ...ahn... wenn sie in einem ganz bestimmten ...ahn... Umweltsverhalten glücklich sind ...ahn... das ist genauso anerzogen wie vieles andre auch... (MAE19)

COMP+: wenn sie ... wie vieles andre auch - dê (ou peça) razões

COMP-: ich bezweifle - minimize a imposição

(PROP/T) [Diskussionsleiterin als Ausnahme] wieso? will ich gar nicht sagen ich bin schließlich auch eine Tochter. und ich bin ich bin vielleicht auch schwierig an und ab. (MAE20)

COMP+: wieso?, ich bin schließlich auch... schwierig an und ab- dê (ou peça) razões

COMP-: will ich gar nicht sagen - utilize formas convencionalizadas 
(PROP/T) [im Kindergarten nicht nur bei der Mutter - positiv angesehen] (ja) da würd ich aber einwenden (ich mein), wenn man eben einmal ne Kindergärtnerin hat, die auf vier Kinder kommt, dann nimmt eben die Kindergärtnerin die Stelle der Mutter ein und die kann ebenso negativen Einfluß haben wie ...ahn... die leibliche Mutter. (MAE21)

DIR: aber, einwenden

$\mathrm{COMP}+$ : eben - crie/pressuponha pontos comuns; wenn man... dann... - exemplo contrário - dê (ou peça) razões

COMP-: ich würde einwenden - gerencie o grau de realidade; ich mein - relativize a própria opinião

(PROP/T) aber ich mein, wenn das Mädchen 90\% mit die ... ahn...das Kind 90\% mit der Kindergärtnerin zusammen ist, ist der Einfluß der Kindergärtnerin natürlich größer als der Mutter... (MAE22)

DIR: aber

COMP+: wenn das Mädchen... als der Mutter - dê (ou peça) razões; natürlich crie/pressuponha pontos comuns

COMP-: ich mein - relativize a própria opinião

(PROP/T) das muß ja nicht die gleiche Kindergärtnerin sein (MAE23)

dir: nicht

$\mathrm{COMP}+$ : dê (ou peça) razões; $j a$ - crie/pressuponha pontos comuns

(PROP/T) (ja) ich mein sie haben vorhin gesagt, daß Ehe und Familie wahrscheinlich schädlich sind. ich glaub, das kann man nicht so einfach sagen ...ahn... ich glaube es liegt vor allen viel dran, daß die Eltern sich um ihre Kinder kümmern (MAE24)

DIR: nicht

COMP+: nicht so einfach - evite discordância: relativize a opinião do interlocutor COMP-: ich mein, ich glaub - relativize a própria opinião; das kann man nicht sagen invoque regras gerais

(PROP/T) [Mütter sollten halbtags arbeiten] ich möchte gerne Frau Kirch dann bitten, ob das Dasein der Mutter und das zur Verfügung Stehen der Mutter etwas ist, was an die Zeit gebunden ist oder an die Art und Weise, wie sie für die Kinder da ist. (MAE25)

COMP+: ob das... ist oder... da ist. - do modo como é formulada, o interlocutor é induzido à resposta que o falante espera-crie/pressuponha pontos comuns

COMP-: ich möchte gerne bitten - utilize formas convencionalizadas 
(PROP/T) aber ich glaub, wenn sie tagsüber immer berufstätig sind, dann sind sie abends oft so: müde, daß sie sich überhaupt nicht mehr also zu aufraffen, dann sich auch noch mal um ihre Kinder zu kümmern. (MAE26)

DIR: aber

COMP+: wenn sie tagsüber... dann... - dê (ou peça) razões; aufraffen - intensifique o interesse: aproxime o interlocutor

COMP-: ich glaub - relativize a própria opinião

(PROP/T) das ist das ist eine Frage des Alters, wie alt das Kind ist, wenn das Kind ...ahn... 5, 6, 3 oder 4 Jahre alt ist ...ahn... (kann sein) braucht er die Mutter, wenn das Kind 14 ist 15 ... ahn... ist es vielleicht ganz froh, daß die Mutter mal nicht da ist... (MAE27)

COMP+: das ist eine Frage des Alters, ...kann sein - evite discordância: relativize a opinião do interlocutor; wenn das Kind 5, 6 .... Mutter mal nicht da ist - dê (ou peça) razões

COMP-: vielleicht - relativize a própria opinião

(PROP/T) [sie ist froh, wenn die Eltern nicht zu Haus sind - warum?] ich kann ihnen eine relativ dumme Antwort darauf geben. das geht bei mir nich etwa so, daß ich dann irgendwelche Freunde empfangen will oder so [...], sondern [..] daß ich sage (ach) (wie schön) ich kann mal lange Fernsehen gucken... (MAE28)

$\mathrm{COMP}+$ : ich sage...gucken - intensifique o interesse: aproxime o interlocutor COMP-: dumme Antwort - dê deferência; relativ, etwa - relativize a própria opinião

(INT) [Vorbilder] ...ahn... das ist aber ich wollte von ihnen eine ganz präzise Antwort (MAE29)

OFF: ich wollte...eine ganz präzise Antwort - dê pistas para associações - a falante explicita suas intenções - implicação: a interlocutora não respondeu conforme o esperado.

COMP-: ich wollte...- afastamento temporal: gerencie a dêixis temporal

(PROP/T) [...] und ich finde, daß es ein Glück ist, das heute die heutige Jugend sich viel weniger an Vorbildern orientiert als die Jugend in der Generation, als also als meine Eltern zum Beispiel noch jung waren... (MAE30)

OFF: ein Glück... die heutige Jugend...weniger an Vorbildern orientiert... - dê pistas para associações - o falante considera melhor não seguir modelos, como antigamente seus pais provavelmente cresceram na época do nazismo - implicação: discorda da opinião implícita da interlocutora, de que ajuventude deve seguir modelos de comportamento.

COMP-: ich finde - relativize a própria opinião

(PROP/T) aber Anhaltspunkte finden sie bei Menschen, die sie umgeben, mit denen sie leben, oder? (MAE31)

DIR: aber

$\mathrm{COMP}+$ : oder? - crie/pressuponha pontos comuns 
(PROP/T) ...ahn... ich sage man weiß es nicht. aber ich glaube doch, daß die Umwelt immer auf einen jungen Menschen abfärbt (MAE32)

DIR: aber, doch

COMP-: ich sage, ich glaube - relativize a própria opinião; man weiß es nicht - utilize

formas convencionalizadas; man - impersonalize: gerencie a dêixis pessoal

(PROP/T) so selbstverständlich ist das nicht, denn sonst wären schwierige Töchter keine schwierigen Töchter (MAE33)

DIR: nicht

COMP+: so selbstverständlich - evite discordância: relativize a opinião do interlocutor; denn sonst... - dê (ou peça) razões

(PROP/T) ...ahn... ich sage man weiß es nicht. vielleicht wehrt sich man manchmal dagegen (MAE34)

COMP-: ich sage, vielleicht, manchmal - relativize a própria opinião; man weiß es nicht - utilize formas convencionalizadas; man - impersonalize: gerencie a dêixis pessoal

(PROP/T) (darf ich dazu mal etwas sagen. ich habe mich [...] sehr intensiv mit Heimerziehung befaßt [..] diese jungen Menschen haben eben gesagt die haben s alle gut mit uns gemeint und das waren alle Persönlichkeiten/ aber welche ist nun richtig? wir haben keinen Richtungspunkt. wir haben keine Orientierungspunkt. das ist das Problem für unser künftiges Leben. (MAE35)

COMP+: ich habe mich... befaßt, diese jungen Menschen... - dê (ou peça) razões; darf ich dazu mal etwas sagen - seja otimista; eben - crie/pressuponha pontos comuns; die haben s alle gut....Problem für unser zukünftiges Leben - intensifique o interesse: aproxime o interlocutor

(PROP/T) [Mütter auch als Mitmenschen] (ja) aber ...ahn... ich mein man sollte vielleicht viel mehr andere Menschen beobachten ständig ihre Reaktionen irgendwie sehen und es auch auswerten, daß man nicht so schnell zu Vorurteilen kommt... (MAE36)

COMP+: (ja) aber... evite discordância: concorde simbolicamente; COMP-: ich mein, vielleicht - relativize a própria opinião; man sollte... impersonalize: gerencie a dêixis pessoal + gerencie o grau de realidade 
(PROP/T) [sie gucken so ein bißchen skeptisch] (ja) (ja) ich gucke skeptisch [sind s auch?] (ja) ein bißchen skeptisch [...] erstens die junge Dame sagte sie möchte nicht heiraten, sie möchte selbständig sein. ich weiß nicht, inwieweit man das als selbständig bezeichnen kann:, das hat mich erst mal so ...ahn... skeptisch berührt (MAE37)

OFF: ich gucke skeptisch - dê pistas para associações - o falante não contribui com nenhuma nova informação - implicação: a afirmação da interlocutora é correta: ele está cético - o que é confirmado a seguir.

COMP+: inwieweit ... als selbständig bezeichnen - evite discordância: relativize a opinião do interlocutor; erstens die junge Dame...das hat mich erst mal so ...ahn... skeptisch berührt - dê (ou peça) razões

COMP-: ich weiß nicht, ein bißchen- relativize a própria opinião; man -

impersonalize: gerencie a dêixis pessoal; die junge Dame - dê deferência

(PROP/T) und das andere ...ahn... das junge Fräulein erst vierzehn hat noch keine Vorstellungen. ...ahn... ich glaube heutzutage ist die Jugend im Alter von 14 schon so weit (ja?), daß sie überhaupt eine Vorstellung hat. (MAE38)

COMP+: ja?, überhaupt - crie/pressuponha pontos comuns

COMP-: ich glaube - relativize a própria opinião

(PROP/T) ich möcht etwas sagen zu dem, was Frl. Fleitner sagt. ich glaube, das ist ein typischer Fehler ihrer Erziehung, das sie sagt, ich kalkuliere mit ein, daß ich mal heiraten werde, denn ich meine so kommen wir mit der Emanzipation nie weiter [...] warum sind wir inzwischen nicht soweit, daß sie sagen ...ahn... ich möchte zunächst einmal meinen Beruf haben [...] warum schränken sie sich sofort wieder ein, indem sie sagen, ich werde doch heiraten? (MAE39)

DIR: Fehler

COMP+: denn... - dê (ou peça) razões; kommen wir..., sind wir ... - inclua falante e interlocutor na atividade: gerencie a dêixis pessoal

COMP-: ich möcht etwas sagen... - utilize formas convencionalizadas; ich glaube, ich meine - relativize a própria opinião; typischer Fehler - invoque regras gerais; Fehler ihrer Erziehung - defocalize os participantes

OFF/aux: warum sind wir... , warum schränken sie sich... - use perguntas retóricas

(PROP/T) (nein) ich halt... ich schränke mich deshalb schon im vorhinein ein ...ahn... in der in der Auswahl meines Berufes. z.B. Lehrerin das heißt Halbtagsstellung (ja) es ist nicht sicher, daß ich heirate, es ist nicht sicher, daß ich mal mich nicht scheiden lassen [...] deswegen ist es auf jeden Fall wichtig, daß ich einen Beruf habe, um selbständig zu sein. aber ich lebe doch vielleicht noch so in der Tradition, daß ich vielleicht doch: ganz gerne heirate und darum kalkuliere ich auch mit ein. (MAE40)

DIR: nein, doch

COMP+: deshalb..., deswegen..., darum... - dê (ou peça) razões; aber ich lebe doch vielleicht noch so in der Tradition... - busque concordância: relativize a própria opinião 
(PROP/T) (ja) (genau) aber das halte ich für einen Fehler ihrer Erziehung, daß sie sich so von vornherein einschränken. (MAE41)

COMP+: (ja) genau aber... - evite discordância: concorde simbolicamente COMP-: das halte ich für... - relativize a própria opinião; Fehler ihrer Erziehung invoque regras gerais

(PROP/T) ich möchte (nein) (MAE42)

DIR: nein

(PROP/T) [..] und ich finde, daß die Gabriele daß daß man sie deswegen nicht anklagen soll, wenn sie gleich mit beiden Rollen hier antritt und sagt, ich richt mich halt so ein, daß ich sie beide bewältigen kann. ich finde, das ist ganz gescheit gedacht. (MAE43, S.18)

COMP+: ich richt mich halt so ein, $d a \beta \ldots$ - intensifique o interesse: aproxime o interlocutor

COMP-: ich finde, ganz - relativize a própria opinião; man nicht... soll impersonalize: gerencie a dêixis pessoal 
Inquérito: MenTAL; Duração: 36'40"; Participantes: 4 (homens); Ocorrências de Dissensão: 19

(EXTM/Strat) ich halte die Bezeichnung nationaler Notstand und und finsteres

Mittelalter für übertrieben und spektakulär... (MEN1)

DIR: übertrieben, spektakulär

COMP-: ich halte ...für... - relativize a própria opinião

(PROP/T) ich möchte aber doch meinen, daß sich hier es um eine geradezu skandalöse Situation handelt unwürdig eines Kulturvolkes und (Herr Prof. Müller) eben leider keine Ausnahme... (MEN2)

DIR: aber doch; keine

$\mathrm{COMP}+$ : eben - crie/pressuponha pontos comuns

COMP-: ich möchte meinen - utilize formas convencionalizadas

(PROP/T) (ja) wir haben jetzt nur das: negative Bild mitgezeigt, daß da dem gegenüber auch sehr positive Beispiele gestellt werden können, ist ganz klar, aber leider ...ahn...ist auch ein derartiger Saal eben keine absolute Ausnahme. (MEN3)

DIR: keine

COMP+: daß da dem gegenüber.... ist ganz klar, aber leider... - evite discordância: concorde simbolicamente; eben - crie/pressuponha pontos comuns

(PROP/T) [die Verhältnisse in Großbritannien sind nicht besser] ...ahn... ich möchte dem gern ein Zitat entgegenhalten das (MEN4)

DIR: entgegenhalten

COMP-: ich möchte gern - utilize formas convencionalizadas

(INT) obwohl wir hier jetzt nicht lauter Zitate ... möchten (MEN5)

DIR: obwohl, nicht

$\mathrm{COMP}+$ : wir - inclua falante e interlocutor na atividade: gerencie a dêixis pessoal; hier jetzt nicht... möchten - dê (ou peça) razões

(PROP/T) (nein) aber grade weil das auch ein Zitat war von dem englischen Gesundheitsminister... (MEN6)

COMP+: nein (concordance) aber... - evite discordância: concorde simbolicamente; grade weil... - dê (ou peça) razões

(INT) (ja) nun wollen wir nicht über die Situation in ...ahn... England sprechen. wir wollen auch nicht den internationalen ...ahn... Vergleich die ganze Sendung hindurch durchdiskutieren, sondern wir wollen...(MEN7)

OFF: wollen nicht ....durchdiskutieren, sondern wir wollen... - dê pistas para associações- o falante insiste em dizer o que não é do interesse da discussão, o que o falante quer apresentar não é do interesse do grupo - implicação: o falante deve abandonar o tópico.

$\mathrm{COMP}+$ : wir - inclua falante e interlocutor na atividade: gerencie a dêixis pessoal 
(PROP/T) wenn das so sein sollte, wie sie sagen, wieso kann es dann kommen, daß man jetzt in Hirsau baut ein Krankenhaus mit tausend Betten, was den ...ahn... Vorstellungen der Weltgesundheitsorganisation [...] widerspricht?...(MEN8)

COMP+: wieso kann es dann... - dê (ou peça) razões

COMP-: so sein sollte - marca a opinião do interlocutor distanciando-a da do falante afastamento epistêmico: utilize verbos modais + gerencie o grau de realidade

(PROP/T) [Prof. Schulze muß vom Krankenhausbau wissen] ich zeichne für dieses Projekt nicht verantwortlich. ich bin auch nicht zugezogen worden dazu und ...ahn... teile die Bedenken, die Herr Fischer hier hervorgebracht hat...(MEN9)

DIR: nicht

$\mathrm{COMP}+$ : und teile die Bedenken, die... - crie/pressuponha pontos comuns

(PROP/T) Ich würde denselben Standpunkt vertreten, nur habe ich diese Bedenken und dann gleich auch Befürchtungen, daß wir nur: das Negative bringen [...] ich glaube auch diese positiven Ansätze sollte man einmal sagen (MEN10)

COMP+: ich würde denselben Standpunkt vertreten, nur... - evite discordância: concorde simbolicamente; wir - inclua falante e interlocutor na atividade: gerencie a dêixis pessoal

COMP-: würde...vertreten, sollte...sagen - gerencie o grau de realidade; ich glaube, einmal - relativize a própria opinião; man... - impersonalize: gerencie a dêixis pessoal

$(\mathrm{PROP} / \mathrm{T})$...ahn... ich möchte nicht bestreiten, daß es Ansätze gibt, aber ich möchte etwas bestreiten, daß es derzeit unter den 59 in der BR bestehenden

Landeskrankenhäusern ei:nes gibt, was sich mit einer ganzen Reihe zur Zeit in England bestehender vergleichen ließe. ...ahn... es wurde gesagt ...ahn... sie brauchten nicht nach England zu fahren um diese Erfahrung zu machen es gibt in der BR Vergleichbares. es gibt das Vergleichbare nicht: auf der Ebene eines Landeskranken...ahn...hauses...(MEN11)

DIR: es gibt... nicht; bestreiten

COMP+: nicht bestreiten, aber... - evite discordância: concorde simbolicamente

COMP-: ich möchte - utilize formas convencionalizadas; es wurde gesagt... -

impersonalize: gerencie a dêixis pessoal

(PROP/T) [...] aus diesem Grunde habe ich ...ahn... das Beispiel eines englischen Krankenhauses gewählt um zu zeigen, daß man dort auch auf dieser großen Ebene mit einem Mamutenkrankenhaus (und mit denen haben wir es natürlich derzeit noch zu tun) (und die sind nicht wegzudiskutieren) daß man dort auch sozialpsychologisch arbeiten kann... (MEN12)

OFF: auch ... mit einem Mamutenkrankenhaus ... arbeiten kann; mit denen haben wir es natürlich derzeit noch zu tun; die sind nicht wegzudiskutieren - dê pistas para associações - o falante retoma três pontos não mais relevantes para a discussão, os quais haviam sido negados anteriormente pelos interlocutores, e os apresenta positivamente - implicação: o falante mantém seu ponto de vista e discorda dos demais. COMP+: aus diesem Grunde habe ich das Beispiel... - dê (ou peça) razões; natürlich crie/pressuponha pontos comuns 
(PROP/T) ...ahn... sie sprachen von Laienarbeit und von dem Appell, der möglicherweise ergehen sollte ... ahn... ich sehe darin auch eine gewisse (ja) Zudeckung von Problemen, denn sehen sie, wer wird dann wahrscheinlich mitarbeiten [...]? Ich finde daß diejenigen, die die härteste Vorurteile haben [...] wahrscheinlich draußen bleiben werden und daß diejenigen, die sowieso geneigt sind [...] daß die es tun und ...ahn... an der grundsätzlichen Situation möglicherweise sich nichts ändern wird [...] und ... ahn... es doch nicht ohne weiteres jetzt anzuknüpfen einfach indem man einen positiven Appell erklärt und sagt ...ahn... nun begreift doch daß das keine Kriminellen sind keine gefährlichen Menschen sind, nun versucht doch selber mitzutragen mitzuhelfen ...ahn... ich ...ahn... das kann ...ahn... sehr kurz greifen dieser dieser Appell. (MEN13)

DIR: doch nicht (anzuknüpfen)...

COMP+: denn... - dê (ou peça) razões; sehen sie, ...nun begreift doch... - intensifique o interesse: aproxime o interlocutor

COMP-: ich finde, eine gewisse, wahrscheinlich, möglicherweise - relativize a própria opinião; Zudeckung - defocalize os participantes

(PROP/T) ich wollte grade das Gegenteil sagen. wir sind alle der Meinung das ist notwendig wir brauchen mehr Ärzte [...] wir haben bei der derzeitigen Quote heute schon nicht alle Stellen besetzt. das heißt also die Verbesserung der Quote wird nicht ohne weiteres auch einen starken Zustrom an Pflegepersonal bringen. und solange aus:schließlich negative Kritik über dieses Personal gebracht wird werden in dieser Form gebracht wird, daß dieses Personal dort als Schläger fungiert, dürfen wir nicht: damit rechnen, daß auch bei einer Verbesserung der Quote nun besseres und mehr Personal zu uns kommt. (MEN14)

DIR: Gegenteil

COMP+: wir sind alle der Meinung - crie/pressuponha pontos comuns; wir sind alle...mehr Personal zu uns kommt - argumentation: dê (ou peça) razões; dürfen wir nicht... - inclua falante e interlocutor na atividade: gerencie a dêixis pessoal OFF/aux: aus:schließlich - dê pistas para associações - um dos participantes insiste, durante toda a interação, em apresentar críticas negativas; o falante assinala tal comportamento como inadequado - implicação: o falante discorda desse participante.

(PROP/T) [Gewalt als Einzelfälle] hier möcht ich widersprechen (MEN15)

DIR: widersprechen

COMP-: ich möchte... - utilize formas convencionalizadas

(PROP/T) [...] und wenn ich auf die Laien zurückkommen darf, so möchte ich nur hinweisen auf die Vereine [...] auf die Aktionsgruppen [...] und ich möchte im besondern hinweisen auch auf die Patenschaften [...] daß auch das: ein Vorurteil ist, daß etwa die Gesellschaft gar nichts von ihren psychischen Kranken wissen wollte... (MEN16)

COMP+: wenn ich ...zurückkommen darf - seja otimista; ...nur hinweisen... - minimize a imposição; auf die Vereine...Aktionsgruppen...Patenschaften - (arguments) - dê (ou peça) razões

COMP-: ich möchte... - utilize formas convencionalizadas;

OFF/aux: auch das: (+intonation) ist ein Vorurteil - dê pistas para associações retoma as palavras do interlocutor, juntamente com o conceito negativo Vorurteil implicação: crítica à opinião do interlocutor; das etwa ... nicht wissen wollte - falante 
sinaliza afastamento da opinião do interlocutor, através de etwa e do Konjunktiv implicação: discordância.

(PROP/T) (ja nun) ich komme dann ich komm auf das zurück, was ich hier auch schon vertreten habe. ich finde das eine rückhaltlose Darstellung. ...ahn... hier wird als nur das Negative bezeichnet. ich finde, man vertuscht eben doch Entscheidendes, wenn man s nicht tut... (MEN17)

DIR: doch, vertuscht

$\mathrm{COMP}+$ : eben - crie/pressuponha pontos comuns

COMP-: ich finde - relativize a própria opinião; wird bezeichnet, man impersonalize: gerencie a dêixis pessoal

(PROP/T) [...] und ...ahn... ich meine ich möcht jetzt nicht auf ...ahn... Verschiedenes noch zurückgehen aber es wird eben hier ...ahn... einzelne Delikte werden

herausgegriffen. es wird so getan, als seien das Einzelfälle. ich würde sagen es ist die Spitze eines Eisberges [...] (MEN18)

$\mathrm{COMP}+$ : eben - crie/pressuponha pontos comuns;

COMP-: ich möchte jetzt nicht...zurückgehen, aber... - indique relutância; ich mein relativize a própria opinião; ich würde sagen... - gerencie o grau de realidade; werden herausgegriffen, es wird...getan - impersonalize: gerencie a dêixis pessoal

(PROP/T) darüber hinaus bin ich aber der Meinung, daß das nun nicht: dem einzelnen Pfleger und dem einzelnem Arzt anzulasten ist, sondern, daß man wirklich die Institution Landeskrankenhaus-heute untersuchen muß... (MEN19)

DIR: aber, nicht: ... sondern

COMP-: ich bin der Meinung - relativize a própria opinião 
Inquérito: MODERADORES; Duração: 10'50"; Participantes: 9 (8 homens, uma mulher); Ocorrências de Dissensão: 6

(PROP/T) [...] wie sie sagen (Herr Pechel) daß nun in der Redaktion also sowohl die die der rechte Flügel der CSU wie die linke Flügel der SPD vertreten seien, die Sache wär etwas unrealistisch, weil ich nicht glaube, daß diese ...ahn... Redaktion funktionieren kann. Ich bin ein Vertreter der Ausgewogenheit... (MOD1)

DIR: unrealistisch

COMP+: weil ich .... - dê (ou peça) razões

COMP-: etwas, ich glaube - relativize a própria opinião; die Sache wäre... - gerencie o grau de realidade

(INT) [(also) wenn es ein und dieselbe Redaktion sein soll mit zwei Moderatoren...] (nein) das haben wir nicht... (MOD2)

DIR: nein, nicht

COMP+: ...haben wir... - inclua falante e interlocutor na atividade: gerencie a dêixis pessoal

(PROP/T) aber finden sie denn, daß man nicht theoretisch auch einen sich einen Kon:trapunkt vorstellen könnte? dasselbe Stück aber nicht ... ahn... daß der Moderator absolut Sprachrohr der Redaktion sein muß, ich stell es nur zur Diskussion. ich bin auch an sich nicht der Meinung (MOD3)

DIR: aber

COMP+: finden sie denn... nicht...? - crie/pressuponha pontos comuns; ich bin an sich auch nicht der Meinung - busque concordância: relativize a própria opinião COMP-: theoretisch, einen Kon:trapunkt - relativize a própria opinião; sich ... vorstellen könnte - gerencie o grau de realidade; ich stell es nur zur Diskussion minimize a imposição

(PROP/T) [Wenn der Film bzw. der Bericht schon gut ist, braucht man keinen Moderator] aber ich glaube, da kommen wir (Dieter Göbel) auf ein Grundproblem des Fernsehens, denn ...ahn... ich glaube man müßte einmal zuerst die Frage stellen kann der Film der politische Filmbericht [...] heute das Abstrakte was in der politischen Aussage ja doch zu einem guten Teil immer noch drinliegen muß, kann er es wirklich ausdrücken? braucht nicht der Filmbericht dazu eben noch (ich möcht jetzt nicht sagen den Ausgleich des Moderators) aber die Ergänzung oder die Vertiefung? (MOD4)

DIR: aber, doch

$\mathrm{COMP}+$ : da kommen wir...- inclua falante e interlocutor na atividade: gerencie a dêixis pessoal; braucht er nicht...eben...? - crie/pressuponha pontos comuns COMP-: ich glaube, einmal, ich möcht nicht sagen den Ausgleich... aber die Ergänzung... - relativize a própria opinião; man - impersonalize: gerencie a dêixis pessoal; müßte...die Frage stellen - gerencie o grau de realidade; kann der Film... es ausdrücken? - evite afirmações: faça perguntas; ich möcht nicht sagen - use convencionalized forms;

OFF/aux: wirklich - dê pistas para associações - o interlocutor havia afirmado que o vídeo já seria suficiente para transmitir a mensagem; o falante questiona se isto é realmente o caso - implicação: ele não pensa assim. 
(PROP/T) ...ahn... das würd ich nicht sagen. denn (schauen sie) ...ahn...was heißt ...ahn... kann das nicht im Filmbericht drin sein die Abstraktion? ...ahn... ein Film heißt ja nicht, daß das etwas ist, was nur aus Zappelbildchen besteht, sondern in dem Film sind natürlich entweder auch Aussagen drin ...ahn... oder aber andere bildliche Umsetzungen im Idealfall abstrakter Probleme. das gelingt mehr oder weniger gut... (MOD5)

DIR: nicht

COMP+: denn... - dê (ou peça) razões; ein Film heißt ja nicht...- crie/pressuponha pontos comuns; schauen sie, Zappelbildchen - intensifique o interesse: aproxime o interlocutor

COMP-: das würd ich nicht sagen - gerencie o grau de realidade; was heißt...? - evite afirmações: faça perguntas; mehr oder weniger - relativize a própria opinião

(PROP/T) es gibt doch Dinge, die man in einem Filmbericht, das was sie Zappelbildchen nennen, gar nicht darstellen kann... (MOD6)

DIR: doch, gar nicht

COMP+: es gibt Dinge... - dê (ou peça) razões;

OFF/aux: das was sie Zappelbildchen nennen - dê pistas para associações - repetição crítica das palavras do outro: ele próprio utilizou essa expressão - implicação: um filme não passa mesmo disso. 
Inquérito: RDA; Duração: 28'06"; Participantes: 4 (3 homens, uma mulher); Ocorrências de Dissensão: 2

(PROP/P) [von Meklenburg bis...] (nein) (nein) ich sprach nur von Meklenburg (GDR1) DIR: nein + informação correta

(PROP/P) (ja) entschuldigen sie aber erst muß ich sie mal ein kleines bißchen berichtigen. sie sagten wir haben die Ernte in die Scheunen gefahren. das is das trifft für unsere Landwirtschaft heute wohl doch nich mehr zu denn das größte ...ahn... das meiste Getreide is von Mähdreschern geernt worden ...ahn... und dann wird das Getreide in Silos gebracht (GDR2)

DIR: aber, trifft nicht mehr

$\mathrm{COMP}+$ : denn das größte... - dê (ou peça) razões

COMP-: entschuldigen sie - peça desculpas; ein kleines bißchen berichtigen minimize a imposição; $i c h m u \beta \ldots$ - indique relutância; $m a l$, wohl - relativize a própria opinião 


\section{Inquérito: SEXo; Duração: 29'45"; Participantes: 9 (7 homens, 2 mulheres);} Ocorrências de Dissensão: 13

(PROP/T) (ja) dazu möchte ich sagen, ich gebe ihnen soweit recht ...ahn... daß tatsächlich die Situation oft so ist, daß ...ahn... das Mädchen mehr Schwierigkeiten hat, ...ahn... sich sich frei gegenüber der Sexualität ...ahn... zu entfalten. aber eben ich möchte nochmal bezug nehmen auf das, was ich vorhin sagte, es ist eben deshalb so, weil sie eben anders erzogen wurde als der Junge. ich glaube, daß von Natur aus ...ahn... ein Unterschied in dem sexuellen Bedürfnis nicht besteht. (SEX1)

DIR: ein Unterschied nicht besteht

COMP+: (ja)... ich gebe ihnen soweit recht, daß..., aber... - evite discordância: concorde simbolicamente; eben - crie/pressuponha pontos comuns; es ist eben deshalb so, weil... - dê (ou peça) razões

COMP-: ich möchte sagen/ bezug nehmen- utilize formas convencionalizadas; soweit, ich glaube - relativize a própria opinião

(PROP/T) (ja) da gibt es eben verschiedene Meinungen (nicht wahr?) (SEX2)

OFF: dê pistas para associações - há opiniões diferentes - implicação: a opinião do falante é diferente daquela da interlocutora.

COMP+: eben, nicht wahr? - crie/pressuponha pontos comuns

(PROP/T) [...] jedenfalls gibt es keine Forschungsergebnisse, die ...ahn... bestätigen, was sie glauben. es ist ein Postulat. (SEX3)

DIR: keine

COMP-: jedenfalls - relativize a própria opinião; keine Forschungsergebnisse - apele à autoridade/objetividade

(PROP/T) insofern als ...ahn... wenn ich die Untersuchungsergebnisse der beiden Hamburger Sexualwissenschaftler Volkmar Sigusch und Gunther Schmidt richtig verstanden habe, dann geht aus den Fragen an bis zu 17 Jahre alten Mädchen und Jungen eindeutig hervor, daß beide Geschlechter mit geringen Prozentunterschieden [...] daß also beide Jungen wie Mädchen der Ansicht sind, ... ahn... beide Geschlechter hätten genau das gleiche sexuelle Bedürfnis nach dem anderen Partner. (SEX4)

COMP+: dann geht aus den Fragen... nach dem anderen Partner - exemplo contrário dê (ou peça) razões

COMP-: Untersuchungsergebnisse - apele à autoridade/objetividade; wenn ich... richtig verstanden habe - dê deferência 
(PROP/T) (ja) aber ich muß da ...ahn... dem eigentlich entgegenhalten, ...ahn... daß das natürlich Ergebnisse sind, die durch Befragung ...ahn... von ...ahn... Personen gewonnen wurden, die bereits einen sehr langen Sozialisationsprozeß hinter sich haben. d.h. sie haben schon [...] gelernt, welche Rolle sie zu vertreten haben... (SEX5)

DIR: entgegenhalten

COMP+: (ja) aber - evite discordância: concorde simbolicamente; ...natürlich crie/pressuponha pontos comuns; Ergebnisse sind... zu vertreten haben - dê (ou peça) razões

COMP-: ich muß entgegenhalten - indique relutância; eigentlich - relativize a própria opinião

(PROP/T) [...] wenn man sagt von Natur aus, dann macht man eine Annahme darüber, wie Sexualität vor irgendwelchem Lernprozeß in dem Einzelnen eingelegt sei. und diesen darüber gibt es zahlreiche Mutmaßungen. aber es gibt keine Bestätigung dafür, daß ...ahn... zum Beispiel ...ahn... daß ...ahn... die die daß dieses ...ahn... die das Rollenstereotyp, was wir haben, Frau passiv Mann aktiv auch zum Beispiel für die Sexualität gültig ist oder nicht gültig ist. es gibt darüber zahlreiche Mutmaßungen. aber keine schlüssigen Beweise, sondern ...ahn... da gehen schon immer wider Konzept einer einer bestimmten Rollenverteilung mit ein zunächst. (SEX6)

DIR: aber, kein

COMP+: wenn man sagt... Mutmaßungen - dê (ou peça) razões; was wir haben -

inclua falante e interlocutor na atividade: gerencie a dêixis pessoal

COMP-: man - impersonalize: gerencie a dêixis pessoal; keine Bestätigung/Beweise apele à autoridade/objetividade

(EXTM) [Frl. Hausländer] Hauswedel bitte (SEX7)

DIR: informação correta

COMP-: bitte - dê deferência

(PROP/T) [Mädchen kennen die Erotik nicht] aber woher sollen sie das wissen? [...] wenn sie die Erziehung bedenken, nach der heute ... ahn... immer noch Kinder erzogen werden sexualfeindlich... (SEX8)

DIR: aber

COMP+: wenn sie die Erziehung bedenken... - dê (ou peça) razões

COMP-: woher sollen sie das wissen? - evite afirmações: faça perguntas - Dissensão com a crítica implícita na contribuição do interlocutor: eles deveriam saber mais sobre erotismo.

(PROP/T) dagegen müssen wir natürlich angehen, aber es gibt ja heute auch ...ahn... sehr viele vernünftige Eltern. (SEX9)

COMP+: dagegen müssen wir natürlich... aber... - evite discordância: concorde simbolicamente; wir - inclua falante e interlocutor na atividade: gerencie a dêixis pessoal; es gibt ja heute auch - crie/pressuponha pontos comuns

(INT) [wenn man diese Zeitanteilung macht] so war das nicht verstanden (SEX10)

DIR: nicht

COMP-: war... verstanden - impersonalize: gerencie a dêixis pessoal 
(PROP/T) (nein) (nein) (nein) so nicht. ich wollte es nur zeitlich etwas ...ahn... etwas einteilen der Klarheit wegen... (SEX11)

DIR: nein, nicht

COMP+: ich wollte es... der Klarheit wegen - dê (ou peça) razões; nur - busque concordância: relativize a própria opinião

(INT) ich glaube, wir müssen jetzt vorsichtig sein, daß wir mit dem Begriff Doppelmoral nicht Verwirrung anstiften. ...ahn... er wird nämlich in zweierlei Bedeutung gebraucht [...] das, was der ...ahn... Hörer eben angesprochen hat, ist offenbar die Doppelmoral, ...ahn... die darauf abzielt... (SEX12)

OFF: müssen vorsichtig sein - dê pistas para associações - qual é o perigo? implicação: este rumo da discussão pode gerar problemas; deve-se mudar o rumo. $\mathrm{COMP}+$ : wir - inclua falante e interlocutor na atividade: gerencie a dêixis pessoal; daß wir... nicht Verwirrung anstiften, er wird nämlich... - dê (ou peça) razões COMP-: ich glaube - relativize a própria opinião;

(PROP/T) (ja) zu der Treue möchte ich gleichzeitig noch auf Herrn Pfarrer Utters zu ...ahn... antworten. und zwar sehe ich in dem in dem Begriff der Treue und in der Praxis der Treue eine Modifikation an sich ...ahn... eines gewisses gewissen Besitzanspruches, der von den einzelnen Partnern dem andern ...ahn... gegenüber ...ahn... gegenüber gebracht wird... (SEX13)

DIR: eine Modifikation - proposição contrária à afirmação do interlocutor, que dissera não ter havido modificações na fidelidade.

COMP-: ich möchte... antworten - utilize formas convencionalizadas; ich sehe, an sich, gewissen - relativize a própria opinião 
Inquérito: TrÂnSITO; Duração: 95'40"; Participantes: 5 (homens) + ouvintes por telefone; Ocorrências de Dissensão: 70

(INT) wenn ich da nen Vorschlag mir erlauben darf, vielleicht heben wir uns das noch 10, 15 Minuten auf... (TRA1)

COMP+: wenn... nen Vorschlag mir erlauben darf - seja otimista; heben wir... - inclua

falante e interlocutor na atividade: gerencie a dêixis pessoal

COMP-: vielleicht - relativize a própria opinião

(PROP/T) (ja) (Herr Littmann) ich glaube, daß die Geschwindigkeitsbegrenzung auch kein Allheilmittel sein kann, denn dann wäre es ja einfach... es mag sein, daß ein oder andre Unfall etwas milder ausfällt, aber [...] und ich glaube nicht, daß die Geschwindigkeitsbegrenzung tatsächlich ein Mittel ist, um nachhaltig gerade diese Zahlen der Toten zu solchen Anlässen wirksam zu senken, weil das wäre furchtbar einfach und wir könnten unsere Diskussion schließen, wenn das so wäre. (TRA2)

DIR: nicht, kein

COMP+: denn..., weil... - dê (ou peça) razões; es wäre ja einfach... - crie/pressuponha pontos comuns; es mag sein, aber... - evite discordância: concorde simbolicamente COMP-: ich glaub - relativize a própria opinião; kein Allheilmittel sein kann afastamento epistêmico: utilize verbos modais

(PROP/T) nun hat man ja aber (und das wissen wir alle [...]) so etwas wie Richtgeschwindigkeit eingeführt. da steht 80 bis $120 \mathrm{Km} / \mathrm{S}$. (Herr Dr. Simsa) wäre denn das ein ...ahn... mögliches Modell, etwas zu bessern? (TRA3)

DIR: aber

$\mathrm{COMP}+: j a$, das wissen wir alle - crie/pressuponha pontos comuns

COMP-: so etwas wie - relativize a própria opinião

(PROP/T) (nur) ob es ein Heilmittel ist, und schon und ob man es überhaupt in Verbindung mit ...ahn... Festtagsunfallziffern ...ahn... so vordergründig in die Diskussion bringen darf, das ist die Frage... (TRA4)

DIR: (nur)

COMP+: $o b$... so vordergründig... - evite discordância: relativize a opinião do interlocutor;

COMP-: man... bringen darf - impersonalize: gerencie a dêixis pessoal; $o b$... ist die Frage - utilize formas convencionalizadas

(INT) (ja) ich glaub wir sollten uns vielleicht überhaupt nich an diese 200 oder zwohundertsoviel Festtags-, Osterfesttagstoten klammern sondern das... (TRA5)

DIR: überhaupt nicht... sondern...

$\mathrm{COMP}+$ : wir sollten uns... - inclua falante e interlocutor na atividade: gerencie a dêixis pessoal

COMP-: ich glaub, vielleicht - relativize a própria opinião; wir sollten... gerencie o grau de realidade

(PROP/T) (ja also) wenn ich was sagen darf, ...ahn... ich halt von den Richtsatzgeschwindigkeiten auch nichts oder (ich möchte es noch deutlicher sagen) gar nichts, denn ... (TRA6) 
DIR: (gar) nichts

COMP+: wenn ich was sagen darf - seja otimista; denn... - dê (ou peça) razões

COMP-: ich möchte... sagen - utilize formas convencionalizadas; ich halt - relativize a própria opinião

(PROP/T) [...] das es an sich hat, es ist net unsinnig. aber unter der gegebenen Situation kann s unverständlich erscheinen, wenn sie sagen, überhaupt kein Verkehr und nun soll ich 100 fahren. aber ich glaub, daß das net möglich ist, daß man einfach immer Klappschilder hintut, die man wieder zudeckt, wenn jetzt 2 Stunden z.B. schnell gefahren werden könnte. also das muß man in Kauf nehmen. (TRA7)

DIR: aber, net möglich

COMP+: das es an sich hat, es ist net unsinnig, aber... - evite discordância: concorde simbolicamente; unter der gegebenen Situation... schnell gefahren werden könnte - dê (ou peça) razões; überhaupt kein Verkehr... fahren, daß man einfach immer... gefahren werden konnte - intensifique o interesse: aproxime o interlocutor

COMP-: ich glaub - relativize a própria opinião; das muß man in Kauf nehmen invoque regras gerais

(PROP/T) das würde ich auch nie vorschlagen... (TRA8)

DIR: nie

COMP+: auch - crie/pressuponha pontos comuns

COMP-: würde...vorschlagen - gerencie o grau de realidade

(PROP/T) [...] deswegen habe ich eine gewisse Sympathie für die Richtgeschwindigkeit, weil sie doch ein Appell an die Eigenverantwortung ist und vielleicht auch besser in die heutige Welt paßt, wo die Menschen nicht mehr Untertan sein will... (TRA9)

DIR: doch

COMP+: deswegen..., weil... - dê (ou peça) razões

COMP-: gewisse, vielleicht - relativize a própria opinião

(PROP/T) [Extramark für Verkehr] ... ein Bataillon von Leuten (lacht) von Leuten, die das nun verwalten und ordnen wollen. Und am Schluß haben wir zu den vielen Institutionen noch eine mehr. ...ahn... und ich fürchte diese diese ganze Sache auch wie mit dem Föderalismus... (TRA10)

OFF: Bataillon von Leuten - exagere

COMP+: ein Bataillon... und am Schluß... und ich fürchte... - dê (ou peça) razões;

(PROP/T) [...] nun zu diesem Vorschlag, wer das finanzieren soll, (also) ich halt von diesem Vorschlag, daß die Autofahrer doch zusätzlich eine Mark dafür bezahlen sollen, davon halte ich nichts, denn man muß sagen, die Autofahrer zahlen bereits genug... (TRA11)

DIR: nichts

COMP+: denn... - dê (ou peça) razões;

COMP-: ich halt - relativize a própria opinião; man muß sagen... - impersonalize: gerencie a dêixis pessoal + indique relutância

(PROP/T) (Herr Littmann) (Herr Littmann) es kommt nicht auf die eine Mark an. das ist sicher. aber dann kommt wieder was und wieder was und immer zusätzlich... (TRA12) 
COMP+: das ist sicher. aber... - evite discordância: concorde simbolicamente; dann kommt... - dê (ou peça) razões; ... wieder was und wieder was... - intensifique o interesse: aproxime o interlocutor

(PROP/T) [...] und man soll damit aufhören, daß immer der Autofahrer noch etwas dazu tun ти $\beta$. der zahlt: bereits genug. Und ob des jetzt eine Mark für das ist und dann kommt der andere und sagt (na) es kommt auf eine weitere Mark auch nicht an und auf die kommt s nicht an (also) ich mein irgendwo ist die Grenze (TRA13)

$\mathrm{COMP+:} \mathrm{der} \mathrm{zahlt:} \mathrm{bereits} \mathrm{genug} \mathrm{-} \mathrm{dê} \mathrm{(ou} \mathrm{peça)} \mathrm{razões;} \mathrm{und} \mathrm{sagt} \mathrm{(na)...} \mathrm{kommt} \mathrm{s} \mathrm{nicht}$ an- intensifique o interesse: aproxime o interlocutor;

COMP-: man soll damit aufhören - invoque regras gerais; ich mein - relativize a própria opinião

(PROP/T) (aber) entschuldigen sie es kommt nicht darauf an ...ahn... es kommt sicherlich nicht auf die eine Mark an. (TRA14)

DIR: aber, sicherlich nicht

COMP-: entschuldigen sie - peça desculpas

(PROP/T) (ja) aber damit hört s ja net auf... (TRA15)

DIR: $n e t$

COMP+: (ja) aber... - evite discordância: concorde simbolicamente; ja - crie/ pressuponha pontos comuns

(PROP/T) [...] vorhin haben wir ja grad gesagt, daß zu wenig geschehen ist, und es wird nicht so sehr an den Mitteln liegen. das glaub ich gar nicht, daß es nur an den Mitteln liegt, daß net vorhanden seien, sondern ...ahn... des liegt eben an was andren an... (TRA16)

DIR: gar nicht

$\mathrm{COMP}+$ : haben wir ja grad gesagt..., des liegt eben... - crie/pressuponha pontos comuns;

COMP-: ich glaub - relativize a própria opinião;

OFF/aux: ...net vorhanden seien - dê pistas para associações - através do uso do Konjunktiv $I$, o falante se exime explicitamente da adesão à informação - implicação: o falante não acredita nela.

(PROP/T) aber (Herr Dr. Seehum) wenn ich sie da ...ahn... unterbrechen darf, dann frage ich mich natürlich, wenn die Mittel vorhanden wären, warum gibt es dann nicht an den an den ...ahn... stark frequentierten Autobahnen... (TRA17)

COMP+: wenn... darf - seja otimista; warum gibt es dann nicht... - dê (ou peça) razões

COMP-: ich frage mich - defocalize os participantes - falante faz pergunta a si mesmo, deslocando o interlocutor

OFF/aux: wenn die Mittel vorhanden wären...- dê pistas para associações - uso do Konjunktiv II - distanciamento - implicação: o falante não acredita na afirmação do interlocutor.

(PROP/T) [...] was wir zentral brauchen, ist nicht ein ein zunächst mal gar nicht mal ein Finanzfundus, der nur wieder zu neuen Streitigkeit führt, sondern zentral erarbeitete Normen... (TRA18) 
DIR: (gar) nicht... sondern...

COMP-: mal - relativize a própria opinião

(PROP/T) ...ahn... es gibt diese es gibt diese Konferenz ja schon [...] aber ganz offensichtlich hat das bisher nichts genützt... (TRA19)

DIR: es gibt... schon - proposição contrária COMP+: aber hat... nichts genützt - busque concordância: relativize a própria opinião;

(PROP/T) (nein) es geht auch tatsächlich darum, daß die freiwilligen

Hilfsorganisationen all der Meinung sind ...ahn... daß ...ahn... in viel größerem Maße sie auch mit Geld ausgestattet sein müßten... (TRA20)

DIR: nein

COMP+: dê (ou peça) razões

COMP-: sein müßten... - gerencie o grau de realidade

(PROP/T) eine viel konkrete Sache (ja) aber dann erst ...ahn... vorläufig fehlt es doch noch völlig an den Normen... (TRA21)

DIR; doch

COMP+: (ja) aber... - evite discordância: concorde simbolicamente; ...fehlt es ... an den Normen - dê (ou peça) razões

COMP-: vorläufig - relativize a própria opinião (como atenuador, reduz o foco para a atualidade, concordando que mais tarde será como o interlocutor diz).

(PROP/T) (nein) es gibt eine Reihe von Vorstellungen (Herr Dr. Simsa) die durchaus zu erfüllen wären, wenn mehr Geld als bisher da wäre ...ahn... aber ...ahn... das ist ...ahn... (glaube ich) bekannt. (TRA22)

DIR: nein, aber

$\mathrm{COMP}+$ : es gibt eine Reihe... - dê (ou peça) razões; das ist bekannt - crie/pressuponha pontos comuns

COMP-: glaube ich - relativize a própria opinião

(PROP/T) (nein) es liegt nicht so sehr am Geld, sondern es liegt tatsächlich daran, daß mehr Initiative entwickelt werden muß... (TRA23)

DIR: nein

COMP+: nicht so sehr am Geld, sondern... evite discordância: relativize a opinião do interlocutor 
(PROP/T) (ja) (also) die Geschwindigkeitsbegrenzungen in Frankreich sind ja zunächst versuchsweise für ein halbes Jahr eingeführt worden auf ganz bestimmten Straßen und ...ahn... nach den Pressemitteilungen soll tatsächlich (allerdings die Zeitraum ist nicht genannt) ...ahn... die ...ahn... die Unfalltoten soll gesunken sein aber der Zeitraum: um wirklich aussagekräftige Ergebnisse zu gewinnen ist zu kurz.[...] daß sie

zurückgegangen sind aber auch nur eine gewisse Zeit. dann war s wieder das gleiche. also man kann nicht sagen deswegen, weil nun nach Einführungen einer Geschwindigkeitsbegrenzung auf bestimmten Straßen zunächst einmal eine Besserung eingetreten ist, daß das auch weiterhin so bleiben wird. der Zeitraum is noch zu kurz um darüber was ...ahn... sagen zu können. (TRA24)

DIR: nicht, aber

COMP+: ... zunächst versuchsweise, allerdings nicht genannt, soll gesunken sein - evite discordância: relativize a opinião do interlocutor; ... aber.... - evite discordância: concorde simbolicamente; ... daß sie zurückgegangen sind... der Zeitraum ist zu kurz... argumento contrários - dê (ou peça) razões

COMP-: man kann nicht sagen... - impersonalize: gerencie a dêixis pessoal

(PROP/T) [der ADAC antwortet] (ja) (nun) also des beantworte ich ... ahn... nach der Straßenverkehrsordnung... (TRA25)

OFF: dê pistas para associações - o falante declara expressamente que falará segundo a regulamentação de trânsito - implicação: ele não fala como indivíduo, nem pelo ADAC.

(PROP/T) aber man kann eben ...ahn... solche Dinge nicht danach ausrichten, wenn einmal ein außergewöhnlicher Zustand wie Schnee herrscht, denn (schauen sie) da müßte man sagen die ganze Fahrbahnmarkierung können wir abschaffen [...] also solche außergewöhnliche Zustände kann man eben eine Dauereinrichtung nicht abstellen (TRA26)

DIR: aber

COMP+: kann eben nicht..., also... - crie/pressuponha pontos comuns; (schauen sie) intensifique o interesse: aproxime o interlocutor; denn... - dê (ou peça) razões;

OFF/aux: die ganze Fahrbahnmarkierung können wir abschaffen - exagere

(PROP/T) und die Einfahrtsmarkierung [...] und die Ansichten darüber sind also technisch sehr laufen technisch sehr auseinander [...] gelb ist wirklich manchmal hebt sich besser ...ahn... dringt besser ...ahn... als ...ahn... Hintergrund durch den Schnee. aber ein großer Effekt kann nicht damit verbunden werden. (TRA27)

COMP+: die Ansichten... sehr auseinander - evite discordância: relativize a opinião do interlocutor; gelb ist wirklich manchmal... aber... - evite discordância: concorde simbolicamente

COMP-: technisch - apele à autoridade/objetividade; kann nicht verbunden werden invoque regras gerais 
(PROP/T) und (schaun sie) man soll nicht immer gleich nach der Regierung oder Reglementierung schreien, sondern es ist eben so, daß die meisten Unfälle durch leichtsinniges Fahren [...] sie sehen also, daß nach wie vor die Hauptunfallursache eben beim Autofahrer wohl selbst zu suchen ist. und das bedarf jahrelanger Arbeit durch Erklärung [...] die Disziplin wird besser, die Sicherheit wird auch besser. aber es geht nicht auf einmal [...] (TRA28)

DIR: nicht ... sondern

$\mathrm{COMP}+$ : schaun sie - intensifique o interesse: aproxime o interlocutor; es ist eben so, sie sehen also - crie/pressuponha pontos comuns; die meisten Unfälle... - dê (ou peça) razões

COMP-: man - impersonalize: gerencie a dêixis pessoal; man soll nicht inmer... invoque regras gerais; wohl - relativize a própria opinião

(PROP/T) ich gebe zu, daß wir natürlich ein Vielzahl von Problemen [...] noch gar nicht abgeschnitten haben. dazu zählt zum Beispiel auch, daß die Bundesregierung für die Jahre 1971 bis 1985 ein umfangreiches Straßenbauprogramm vorhat [...] ich bitte sie auch diese Überlegungen mit einzubeziehen. das sind natürlich auch alles Merkmale, die man mit erwähnen muß, die dazu beführen können, daß die Unfälle auf der Autobahn mit vermindert werden. (TRA29)

COMP+: ich gebe zu...ein Vielzahl von Problemen... ich bitte sie auch diese

Überlegungen mit einzubeziehen - evite discordância: relativize a opinião do interlocutor; dazu zählt zum Beispiel auch... - exemplo contrário - dê (ou peça) razões; das sind natürlich... - crie/pressuponha pontos comuns

COMP-: ich bitte sie - dê deferência; die man mit erwähnen muß - impersonalize: gerencie a dêixis pessoal

(PROP/T) [Regierung sollte beurteilt werden; Verkehrsprobleme wichtiger als Gespräche mit dem Osten] (na ja) ich glaube, wer hier sorgfältig zugehört hat, der wird sich sein eigenes Bild auf diesen Vorschlag von Herrn Steinmüller selber machen können. ich möchte ihm nur sagen das Problem ...ahn... ist keines, das jetzt diese Bundesregierung erstmalig vor sich sieht... (TRA30)

OFF: - wer hier sorgfältig zugehört hat, der wird sich sein eigenes Bild... machen können - falante evita comprometer-se, cada um formará a sua opinião - seja vago; sorgfältig guia os interlocutors: a sugestão não tem nada a ver com a discussão até o momento; das Problem ist keines... - o problemanão apareceu agora, durante este governo - implicação: não se pode culpar o governo pelo problema - dê pistas para associações

COMP-: ich glaube - relativize a própria opinião; ich möchte ihm nur sagen minimize a imposição; ich möchte... - utilize formas convencionalizadas OFF/aux: (na ja) indica leve desaprovação - implicação: o falante não está satisfeito com algum ponto na contribuição do interlocutor. 
(PROP/T) und über die Gespräche mit dem Osten braucht wohl hier heute nicht zu diskutiert ...ahn... ich sage nur Herr Steinmüller scheint zu den wenigen in unserem Volke zu zählen, die das nicht begrüßen. (TRA31)

REDRESS-; braucht nicht zu diskutiert - impersonalize: gerencie a dêixis pessoal; $i c h$ sage nur - minimize a imposição; scheint, wohl - relativize a própria opinião OFF: zu den wenigen...die das nicht begrüßen - dê pistas para associações - o falante diz que são pucos os que são contra o contato com a Alemanha Oriental - implicação: ele é a favor dos contatos e contra o interlocutor.

(PROP/T) [man darf ja nicht immer an die Bundesregierung denken] man darf auch nicht immer an den Kraftfahrer denken, wie Herr Dr. Seehum aber etwas ausschließlich getan hat (TRA32)

DIR: nicht, aber

COMP-: man darf auch nicht immer... - invoque regras gerais

OFF/aux: etwas ausschließlich - seja irônicoal

(PROP/T) nicht nur ...ahn... (TRA33)

DIR: nicht

COMP+: evite discordância: relativize a opinião do interlocutor

(PROP/T) [bis zu einem gewissen Grade hat die Bundesregierung mit dem Verkehr nichts zu tun] (nein) (nein) (TRA34)

DIR: nein

(PROP/T) bis zu einem gewissen Grade sind für solche konkrete Fragen eben Behörden zuständig, die nur allzu leicht ihre Hände in Unschuld waschen...(TRA35)

DIR: contrary propostion

COMP+: dê (ou peça) razões; eben - crie/pressuponha pontos comuns

REDRESS:- bis zu einem gewissen Grade - relativize a própria opinião

OFF/aux: ihre Hände in Unschuld waschen - use metáforas

(PROP/T) letzteres stimmt. nur die Verantwortung würde ich also nicht abwälzen wollen von denen die (TRA36)

DIR: nicht

COMP+: letzteres stimmt. nur... - evite discordância: concorde simbolicamente;

COMP-: würde ich nicht abwälzen wollen - defocalize os participantes

(PROP/T) (nein) aber man darf es auch nicht zu weit treiben. wir leben ja nicht mehr unter Adolf Hitler, daß nun alles aus Berlin geschieht (TRA37)

COMP+: (nein) aber... - evite discordância: concorde simbolicamente wir leben ja nicht mehr... - crie/pressuponha pontos comuns

COMP-: man darf... nicht zu weit treiben - invoque regras gerais

OFF/aux: wir leben nicht mehr... alles aus Berlin geschieht - dê pistas para associações - idéia de dependência do governo é ligada a conotações negativas, como a figura de Hitler - implicação: falante não acha que tudo seja culpa do governo, os cidadãos também têm a sua responsabilidade. 
(PROP/T) (also) es müssen alle zusammen wirken. und ich ...ahn... sag immer und beton es auch wieder, wenn das Streben nach Verkehrssicherheit nicht eine

Volksbewegung wird, an der jeder das seine beiträgt, dann wird s eben nicht ...ahn... so vollkommen, wie man sich s vorstellt. (TRA38)

OFF: wenn das Streben...wie man sich $s$ vorstellt - exagere

$\mathrm{COMP}+$ : (also) es müssen alle zusammenwirken, es wird eben nicht - crie/pressuponha pontos comuns; ich sag immer und beton es auch wieder... - intensifique o interesse: aproxime o interlocutor COMP-: man - impersonalize: gerencie a dêixis pessoal

(INT) ich möcht nur zu ...ahn... der Gefährlichkeit ganz kurz sagen, daß ich beruflich sämtliche Fahrzeugklassen zu fahren habe und zwar intensiv vom Kleinwagen bis zum schnellsten, und daß ich festgestellt habe, der Mensch stellt sich mehr als man glaubt auf die Eigenschaften seines Wagens... (TRA39)

OFF: der Mensch stellt sich... seines Wagens - dê pistas para associações - o homem se adapta com facilidade ao carro - implicação: não é correto que pessoas que aprenderam a dirigir em carro autimático tenham grandes problemas com o câmbio normal.

COMP+: daß ich beruflich...bis zum schnellsten - exemplo próprio como autoridade dê (ou peça) razões

COMP-: ich möcht nur ganz kurz sagen - minimize a imposição; der Mensch stellt sich... seines Wagens- invoque regras gerais

(PROP/T) (also) hierzu kann ich nur folgendes sagen. wir sind froh, daß endlich die unterschiedliche Handhabung in den Ländern beseitigt, daß der Führerschein...ahn... bewerber oder -inhaber keinen Eintrag kriegt keinen beschränkenden Eintrag nur deswegen, weil er auf Automatik geschult oder geprüft worden ist, denn (schauen sie) es sind zwischen den einzelnen Fahrzeugtypen weit größere Unterschiede als zwischen den Fahrzeugen mit Automatik und ...ahn... sonst normaler Kupplung... (TRA40)

OFF: wir sind froh, daß endlich... - dê pistas para associações - por que ele está feliz com o fim das restrições? - implicação: ele é contra as restrições.

$\mathrm{COMP}+$ : schauen sie - intensifique o interesse: aproxime o interlocutor; wir sind froh...denn... - dê (ou peça) razões

COMP-: hierzu kann ich nur folgendes sagen - indique relutância; es sind zwischen...normaler Kupplung - invoque regras gerais

(PROP/T) ...ahn... (entschuldigen sie) die is ja jedenfalls bei uns in den Bundesländern einheitlich. [..] bei der Klasse 2 werden zusätzliche Fragen gestellt [...] aber sonst sind sie einheitlich (TRA41)

DIR: die ist... einheitlich - proposição contrária

COMP+: bei Klassse 2... aber sonst... - evite discordância: concorde simbolicamente; ja - crie/pressuponha pontos comuns

COMP-: entschuldigen sie - peça desculpas; jedenfalls - relativize a própria opinião

(INT) ich glaube sie haben mich nicht ganz richtig verstanden (TRA42)

COMP-: ich glaube, ganz - relativize a própria opinião; sie haben mich nicht... verstanden - minimize a imposição 
(PROP/T) (doch) (TRA43)

DIR: doch

(PROP/T) die theoretische Seite die ... ahn... (schauen sie) es ist doch gleich, ob er ein ein Kreuz ...ahn... macht ner bei der richtigen Frage, oder er schreibt ja hin oder schreibt nein hin oder die Frage wird beantwortet. (also) gerade in der theoretischen Prüfung sind die Unterschiede durchaus ...ahn... nicht so, wie sie sagen... (TRA44)

DIR: doch, durchaus nicht

$\mathrm{COMP}+$ : schauen sie - intensifique o interesse: aproxime o interlocutor; es ist gleich, ob... wird beantwortet - dê (ou peça) razões; also - crie/pressuponha pontos comuns

(PROP/T) ich möchte nur ausdrücklich sagen ...ahn... daß die Unfallrettung keine sekundäre Frage ist, denn [...] die sind Programme auf lange Sicht [...] aber die Unfallrettung ist ein aktuelles Problem und damit sehr wichtig (TRA45)

DIR: keine sekundäre Frage

COMP+: denn... sehr wichtig - dê (ou peça) razões

COMP-: ich möchte nur ausdrücklich sagen - minimize a imposição; ich möchte... -

utilize formas convencionalizadas

(PROP/T) aber man müßte sagen zunächst Schwerpunkt auf den Verhalten auf den Maßnahmen, die ich sagte, um von vornherein schon Menschenleben zu retten. die zweite Sache ist natürlich, wenn der Unfall passiert ist, die Tätigkeit des

Unfallrettungsdienstes. das ist ganz klar. (TRA46)

DIR: aber

COMP+: ...um von vornherein...zu retten - dê (ou peça) razões; die zweite Sache ist natürlich... das ist ganz klar - crie/pressuponha pontos comuns

COMP-: man müßte sagen... impersonalize: gerencie a dêixis pessoal + indique relutância + gerencie o grau de realidade;

(PROP/T) [auch Berufskraftfahrer fahren im Nebel mit Standlicht] (ja) (also) ich würde sagen des is ...ahn... kann ja vorkommen, aber des is dann (ja) Dußligkeit (TRA47)

DIR: aber

$\mathrm{COMP}+$ : des kann ja vorkommen, aber... - evite discordância: relativize a opinião do interlocutor

COMP-: ich würde sagen - gerencie o grau de realidade

(PROP/T) [Betrunkene Fahrer sollten Unfallkosten bezahlen] (nein) (TRA48)

DIR: nein 
(PROP/T) (also) das muß abgelehnt werden, denn [...] das ist nicht Sinn und Zweck der Haftpflichtversicherung in der Weise Verkehrserziehung zu betreiben, denn damit würde man meines Erachtens [...] die Unfallflucht noch mehr begünstigen [...] da muß man andere Mittel finden als das vorgeschlagene.(TRA49)

DIR: ablehnen, andere Mittel

COMP+: denn... - dê (ou peça) razões;

COMP-: das muß abgelehnt werden - invoque regras gerais; ... abgelehnt werden, da muß man...finden - impersonalize: gerencie a dêixis pessoal; meines Erachtens relativize a própria opinião

(PROP/T) [stärkere Strafen für Trunkenheit] (Herr Littmann) dazu muß man sagen daß ja noch vor knapp einem Jahr [...] jeden [...] in s Gefängnis gesperrt hat, wenn er in betrunkenem Zustand ein Kraftfahrzeug gelenkt hat. und was war die Folge? die Trunkenheitsdelikte haben nicht: abgenommen... (TRA50)

DIR: nicht:

COMP+: daß ja noch... - crie/pressuponha pontos comuns;

COMP-: dazu muß man sagen - impersonalize: gerencie a dêixis pessoal + indique relutância; noch vor knapp ein Jahr... nicht abgenommen - exemplo contrário - dê (ou peça) razões

OFF/aux: was war die Folge? - use perguntas retóricas

(PROP/T) [Hundesteuergeld für den Verkehr] jetzt kommen aber die Hunde ... jetzt kommen die Hundefreunde (ja)... (TRA51)

OFF: seja incompleto - implicação: os amantes de cães irão protestar também.

(PROP/T) darf ich darf ich folgendes sagen? (gnädige Frau) wir sind auch: dagegen. es handelt sich nicht um eine Steuer (zunächst mal zur Klarstellung) sondern es soll eine Mark zusätzlich ...ahn... aufgebracht werden, die zweckgebunden für das Rettungswesen Verwendung finden soll. ich war auch dagegen, aber, wenn sie die Hundesteuer ... ahn... hier anführen, dann muß ich sagen die is auch: schon zu hoch... (TRA52)

DIR: dagegen, aber

COMP+: es handelt sich nicht... finden soll - dê (ou peça) razões; ich war auch dagegen aber... - crie/pressuponha pontos comuns

COMP-: darf ich folgendes sagen?, gnädige Frau - dê deferência; dann muß ich sagen... - indique relutância

(INT) ...ahn... (Frau ...) ich wollte sie nur darauf aufmerksam machen, ...ahn... daß ...ahn... eine (ja) [...] Mark mehr für Autofahrer oder daß sie schlechthin den Autofahrer nicht mit dem Hund vergleichen können. ich bitte sie wirklich das zu sehen. ...ahn... ich habe auch Verständnis dafür, daß sie irgendwo Sorgen mit Hunden haben [...] seien sie so freundlich und halten sie das (bitte) auseinander das ist nicht vergleichbar. (TRA53)

DIR: nicht

COMP+: ich habe auch Verständnis... Sorgen mit Hunden haben - crie/pressuponha pontos comuns

COMP-: ich wollte nur... - minimize a imposição + afastamento temporal: gerencie a dêixis temporal; ich bitte sie wirklich, bitte- dê deferência; seien sie so freundlich utilize formas convencionalizadas; das ist nicht vergleichbar - invoque regras gerais 
(PROP/T) [tote Schilder] (na ja) da kann man ja nur sagen so tot sind die Schilder ja nicht. sie sind ja rückstrahlend... (TRA54)

DIR: nicht

$\mathrm{COMP}+$ : so tot sind die Schilder ja nicht - evite discordância: relativize a opinião do interlocutor; sie sind ja... - crie/pressuponha pontos comuns; sie sind ja rückstrahlend - dê (ou peça) razões

COMP-: da kann man nur sagen- impersonalize: gerencie a dêixis pessoal + indique relutância

OFF/aux: (na ja) + entonação: indica contrariedade.

(INT) aber ich glaube der Anrufer möchte im Grunde nur, daß wirkliche Gefahrenstellen eben besser ... ahn... und deutlicher markiert werden... (TRA55)

DIR: aber

COMP+: ...Gefahrenstellen eben besser... - crie/pressuponha pontos comuns

COMP-: ich glaube, im Grunde - relativize a própria opinião

(PROP/T) [Wagen nicht mehr in Raten verkaufen] da muß ich aber widersprechen. ich kenne doch die DDR die sparen sich das natürlich auch zusammen. sie müssen deswegen nur länger warten.(TRA56)

DIR: widersprechen

COMP+: ich kenne doch die DDR... länger warten - dê (ou peça) razões

COMP-: ich muß widersprechen - indique relutância; ich glaube - relativize a própria opinião

(PROP/T) [Wagen als Statussymbol] ...ahn... (nein) ich glaube, die Anruferin unterschätzt die Folgen unserer Siedlungspolitik [...] wenn sie das Kraftfahrzeug nicht hätten, könnten sie gar nicht mehr zur Arbeit kommen... (TRA 57)

DIR: nein

COMP+: die Anruferin unterschätzt... zur Arbeit kommen - dê (ou peça) razões

COMP-: ich glaube - relativize a própria opinião

(PROP/T) zu diesem Vorschlag mu $\beta$ man einfach sagen, man kann nicht Verkehrspolitik dadurch betreiben, daß sich nur finanziell Gutgestellte ein Auto leisten kann, das ist kein Weg zu einer vernünftigen Verkehrspolitik. (TRA58)

DIR: kein Weg, nicht

COMP-: $m u ß$ man einfach sagen - impersonalize: gerencie a dêixis pessoal + indique relutância; man kann nicht... - invoque regras gerais 
(PROP/T) [langsamer Fahrer am gefährlichsten] (ja) (also) ...ahn... da kann man nur sagen, daß das eine unbewiesene Behauptung ist. richtig ist, daß auf der Autobahn, wenn es die Lage erfordert, zügig gefahren werden soll und auch mu $\beta$ [...] aber, daß die Langsamfahrer einen Großteil der Unfälle verursachen, das kann man einfach nicht beweisen. daß sie eine Behinderung sind, wenn sie nicht so zügig fahren, wie sie könnten, das steht außer Zweifel. (TRA59)

DIR: unbewiesen, nicht

$\mathrm{COMP}+$ : richtig ist...und auch $m u \beta$, aber... - evite discordância: concorde simbolicamente; das sie eine Behinderung... außer Zweifel - crie/pressuponha pontos comuns

COMP-: da kann man nur sagen - impersonalize: gerencie a dêixis pessoal + indique relutância; unbewiesene Behauptung - defocalize os participantes; das kann man einfach nicht beweisen - invoque regras gerais

(PROP/T) [Rotes-Kreuz-Wagen in regelmäßigen Abständen an der Autobahn] [...] sie können nicht an allen Tagen da stehen, denn ich bitte unsern Fragesteller auch zu bedenken, daß die Leute [...] im jetzigen Stadium ist es einfach nicht möglich von der Besatzung und der Unterhaltung her dieser Fahrzeuge überall an kritischen Punkten ständig (rund um die Uhr sozusagen) jemanden stehen zu haben. (TRA60)

DIR: nicht, nicht möglich

COMP+: sie können nicht... denn... - dê (ou peça) razões; rund um die Uhr (sozusagen)

- intensifique o interesse: aproxime o interlocutor

COMP-: ich bitte... - dê deferência

(EXTM) ... Anreiz, wenn ich das noch einwerfen darf, ...ahn... ehrenamtlich das klingt doch immer so ...ahn... $n$ bißchen ...ahn... als [...] außerdem könnte man vielleicht einen gewissen finanziellen Anreiz schaffen... (TRA61)

DIR: doch

COMP+: wenn ich das noch einwerfen darf... - seja otimista

COMP-: so $n$ bißchen, gewissen, vielleicht - relativize a própria opinião

(EXTM) [abwertend?] nicht abwertend, aber ... ahn... die armen Dummen die stehen an der Autobahn... (TRA62)

DIR: nicht... aber

$\mathrm{COMP}+$ : die armen Dummen... - intensifique o interesse: aproxime o interlocutor; die stehen an der Autobahn.. - dê (ou peça) razões

(PROP/T) [regelmäßige Prüfung für Fahrer] (also) generell kann man nur sagen, daß das nicht möglich ist, denn [...] man bezahlt dafür eine Gebühr, ohne daß für die Verkehrssicherheit etwas gewonnen wird. das kann man einfach nicht machen. (TRA63)

DIR: nicht möglich, nicht

COMP+: denn... - dê (ou peça) razões

COMP-: man kann nur sagen - impersonalize: gerencie a dêixis pessoal + indique relutância; generell - relativize a própria opinião; das kann man einfach nicht machen - invoque regras gerais 
(PROP/T) [Jugendliche sollten mehr Versicherung zahlen] (ja) es ist natürlich richtig, daß diese Jugendlichen [...] mehr an Unfällen beteiligt sind [...] man befaßt sich mit diesem Problem schon seit langem, aber man weiß ...ahn... noch nicht, wie man ...ahn... diesem Problem beikommen kann. jedenfalls nicht in der Weise, daß man etwa vor 25 niemanden einen Führerschein erteilen darf. (TRA64)

DIR: nicht COMP+: (ja) es ist... richtig... aber... - evite discordância: concorde simbolicamente; jedenfalls nicht in der Weise... erteilen darf - invoque regras gerais

(PROP/T) (genau) ich wollte also sagen ich würde ganz energisch widersprechen. zunächst darf man überhaupt nicht verallgemeinern (nicht wahr?) und das is is is sowieso falsch. und ... ahn... jemand hier bis 25 Jahren nicht zusprechen zu wollen, das er ...ahn... einen Führerschein erhält geht gar nicht. junge Leute im Alter zwischen 18 und 25 Jahren haben im Berufsleben ...ahn... auch wesentliche Aufgaben, die sie einfach mit dem Auto zurücklegen müssen (nicht?) (TRA65)

DIR: widersprechen, überhaupt nicht, falsch, geht nicht

COMP+: junge Leute im Alter... zurücklegen müssen - dê (ou peça) razões; nicht wahr?, nicht? - crie/pressuponha pontos comuns

COMP-: ich wollte sagen - afastamento temporal: gerencie a dêixis temporal; $i c h$ würde widersprechen - gerencie o grau de realidade, nicht zusprechen zu wollen impersonalize: gerencie a dêixis pessoal; man darf nicht verallgemeinern, das ist sowieso falsch - invoque regras gerais

(PROP/T) (also) ...ahn... auch dagegen bin ich, daß ...ahn... die jungen Fahrer von vornherein mit einem Zuschlag belastet werden. Es ist doch bei uns so, daß ohnehin: derjenige, der einen Unfall ... ahn... hat [...] er muß dann eine höhere Prämie zahlen [...] aber ihn von vornherein schlecht einzustufen das wäre verkehrt...(TRA66)

DIR: dagegen bin ich, verkehrt

COMP+: es ist doch... höhere Prämie zahlen... aber... - evite discordância: concorde simbolicamente

REDRESS: das wäre verkehrt - gerencie o grau de realidade

(PROP/T) [Zu viele Extras im Auto] (ja) das läuft ...ahn... zu beträchtlichen Kosten auf [...] man kann das einfach nicht in die Serienpreise unterbringen. das nehme ich der Automobilindustrie ohne weiteres ab [...] dann kann ... ahn... jeder muß eben für seine Sicherheit auch zahlen wollen. (TRA67)

DIR: nicht

COMP+: das läuft zu beträchtlichen Kosten auf...unterbringen - dê (ou peça) razões; jeder muß eben... - crie/pressuponha pontos comuns

COMP-: man kann das einfach nicht in die Serienpreise unterbringen, jeder mu $\beta$ auch zahlen wollen - invoque regras gerais 
(PROP/T) [Geh- oder Fahrverbot bei Nacht] das find ich unerträglich, wenn wir nicht mehr ...ahn... wenigstens $n$ bißchen rumlaufen dürfen. das ist immer das Problem (TRA68)

DIR: unerträglich

COMP+: $n$ bißchen rumlaufen - intensifique o interesse: aproxime o interlocutor

COMP-: das find ich - relativize a própria opinião;

OFF/aux: wenn wir nicht mehr wenigstens...rumlaufen dürfen ... - exagere; das ist immer das Problem - seja vago

(PROP/T) der Vorschlag läßt sich nicht verwirklichen. (TRA69)

DIR: nicht

COMP-: der Vorschlag - defocalize os participantes; ...läßt sich nicht verwirklichen impersonalize: gerencie a dêixis pessoal

(PROP/T) aber die USA sind kein Traumland der ...ahn... gegen Verkehrsunfallziffern. ...ahn... umgerechnet ...ahn... Indexziffern sind ... ahn... sogar höher als bei uns aus Gründen, die aber nun wieder mit ... ahn... großen Fahrstrecken und so weiter zusammenhängen. (TRA70)

DIR: kein

COMP+: umgerechnet...zusammenhängen - dê (ou peça) razões; die aber nun wieder... - busque concordância: relativize a própria opinião

OFF/aux: die USA sind kein Traumland... - use metáforas 
Inquérito: UlbRICHT; Duração: 24'45"; Participantes: 5 (homens); Ocorrências de Dissensão: 22

(PROP/T) wenn politische Gründe sein sollten, was wir wirklich nicht wissen, was wir als eine Möglichkeit ...ahn... aber nicht vielleicht nicht einmal als eine

Wahrscheinlichkeit nennen können, dann glaube ich nicht, daß sie dort liegen ...ahn... wie ich aus ihren Worten entnahm, ich glaube nich, daß man Ulbricht in den

Hintergrund drängen wollte mit diesem Fernbleiben... (ULB1)

DIR: nicht

$\mathrm{COMP}+$ : wir...wissen/können- inclua falante e interlocutor na atividade: gerencie a dêixis pessoal; Möglichkeit, vielleicht nicht einmal Wahrscheinlichkeit - evite discordância: relativize a opinião do interlocutor

COMP-: ich glaube, wie ich aus ihren Worten entnahm - relativize a própria opinião

OFF/aux: wenn... sollten - dê pistas para associações - o falante distancia-se da opinião do interlocutor através do verbo sollen e do Konjunktiv - implicação: não concorda com essa opinião.

(PROP/T) [Vorschußlorbeeren an Honecker] ...ahn... (ja) ...ahn... ich glaube, daß ...ahn... die freundlichen Worte, die Breschnjew für Honecker gefunden hat, ...ahn... noch nicht sehr viel besagt. nachdem Moskau zugestimmt hat zu dieser Nachfolge ...ahn... ist es selbstverständlich, daß er diesen neuen man stützen muß... (ULB2)

COMP+: ...noch nicht sehr viel besagt - evite discordância: relativize a opinião do interlocutor; nachdem Moskau...stützen mu $\beta$ - dê (ou peça) razões;

COMP-: ich glaube - relativize a própria opinião

(PROP/T) (ja) ich glaub ja nicht, daß die so sentimental sind, daß also der Umstand Lennin gekannt zu haben sie all:zu sehr beeindruckt... (ULB3)

DIR: nicht

COMP-: ich glaub, allzu - relativize a própria opinião

(PROP/T) (ja) ich weiß nicht, ob nicht vielleicht doch Ulbricht ... ahn... nicht nur menschlich sondern auch politisch etwas unbequemer und schwerer zu handhaben war für die Parteiführung in Moskau [...] das sind auch: Spekulationen. wir wissen auch nicht, aber er hat da eins ...ahn... (ULB4)

DIR: doch, aber

COMP+: wir wissen... - inclua falante e interlocutor na atividade: gerencie a dêixis pessoal

COMP-: ich weiß nicht, ob... - utilize formas convencionalizadas; das sind auch Spekulationen - minimize a imposição; vielleicht, etwas - relativize a própria opinião

(PROP/T) [was sie: eben sagten ... würde damit nicht ganz: übereinstimmen] wieso eigentlich? (ULB5)

COMP+: wieso? - dê (ou peça) razões

OFF/aux: eigentlich - dê pistas para associações: o falante não vê como o que o interlocutor sugere seja possível. 
(PROP/T) [was sie: eben sagten ... würde damit nicht ganz: übereinstimmen] (nein) (ULB6)

DIR: nein

(PROP/T) [zu ULB6] nicht? (ULB7)

DIR: nicht

COMP-: nicht? - evite afirmações: faça perguntas

(PROP/T) [zu ULB7] wieso? (ULB8)

$\mathrm{COMP}+$ dê (ou peça) razões

(PROP/T) [zu ULB 7] warum nicht? (ULB9)

COMP+: dê (ou peça) razões

(PROP/T) denn ...ahn... in diesem Sinne würde sich doch auch Ulbricht geäußert haben und h:at er sich auch schon geäußert... (ULB10)

DIR: doch

$\mathrm{COMP}+$ : denn... - dê (ou peça) razões

(PROP/T) (sie meinen?) (ULB11)

$\mathrm{COMP}+$ : dê (ou peça) razões

(PROP/T) das ist nie angenommen worden (ULB12)

DIR: nie

COMP-: impersonalize: gerencie a dêixis pessoal

(PROP/T) ...ahn... eigentlich nicht schärfer als bisher... (ULB13)

COMP+: nicht schärfer - evite discordância: relativize a opinião do interlocutor

COMP-: eigentlich - relativize a própria opinião

(PROP/T) (ja) ich meine doch: (ich ...ahn... mich da irren) (vielleicht habe ich das vor Honecker nicht genau genug beobachtet) das eine Verschärfung darin liegt nämlich in den Adjektiven [...] so: habe ich bisher noch nicht gehört. das wäre, wenn ich recht habe und nichts überhört hatte, dann eben doch eine Verschärfung... (ULB14)

DIR: doch

COMP+: nämlich in den Adjektiven...noch nicht gehört - dê (ou peça) razões; eben crie/pressuponha pontos comuns

COMP-: ich meine, ich glaube, vielleicht - relativize a própria opinião; ich... mich $d a$ irren, nicht genau genug beobachtet, wenn ich recht... nichts überhört hatte - dê deferência; das wäre... eine Verschärfung - gerencie o grau de realidade

(PROP/T) das entspringt aber eigentlich der Logik der Partei, denn, je schärfer der Klassenkampf wird, um so schärfer muß auch die Abgrenzung werden... (ULB15)

DIR: aber

COMP+: denn... - dê (ou peça) razões

COMP-: eigentlich - relativize a própria opinião 
(PROP/T) [...] das ist etwas, was bei anderen Politikern und schon gar bei Honecker ...ahn... nirgends zu sehen war. und ich glaube hier liegt wirklich ein Unterschied ...ahn..., der vermerkt werden muß. (ULB16)

COMP+: das ist etwas... zu sehen war - dê (ou peça) razões

COMP-: ich glaube - relativize a própria opinião; vermerkt werden mu $\beta$ impersonalize: gerencie a dêixis pessoal

(PROP/T) [Ulbricht neigt zu der 2. Linie] das mag sein. aber es läßt sich eins mit dem andern verbinden... (ULB17)

DIR: aber

COMP+: das mag sein, aber... - evite discordância: concorde simbolicamente

(PROP/T) ...ahn... (ja) wenn es nun um Zahlungen gehen ...ahn... geht ...ahn... ist das ist das natürlich möglich. aber von einem bestimmten Punkt an geht es eben schlecht... (ULB18)

DIR: aber

COMP+: wenn es um Zahlungen gehen..., von einem bestimmten Punkt an... - avoid disagreement: relativize the interloctor's opinion; ... möglich, aber... - evite discordância: concorde simbolicamente; eben, natürlich - crie/pressuponha pontos comuns

(PROP/T) [scharfe Trennung zur BRD] nur dann, wenn die Sowjetunion auf der Seite der von ihnen gekennzeichneten Haltung steht. ist die Sowjetunion der Meinung, daß auch Polen und Tschechoslowakei und Ungarn sich entsprechend zurückhalten sollten, dann hätte die SED es nicht schwer. (ULB19)

COMP+: nur dann, wenn... - evite discordância: relativize a opinião do interlocutor; ist die Sowjetunion der Meinung... - exemplo contrário - dê (ou peça) razões

(PROP/T) (ja) aber, wie wir gesehen haben in letztem Jahr ...ahn... so haben ...ahn... sich doch die Polen vor allen Dingen die Polen aber eben zum Teil auch die Sowjetunion selbst: nicht zu einer solchen Abgrenzung und Ab:sprerrung entschlossen... (ULB20)

DIR: doch

COMP+: (ja) aber... - evite discordância: concorde simbolicamente; wir - inclua falante e interlocutor na atividade:gerencie a dêixis pessoal; so haben sich doch... exemplo contrário - dê (ou peça) razões

(PROP/T) [darf ich mal ihren Dialog unterbrechen...] bloß ich meine wir sollten ... ahn... um noch mal an das anzuknüpfen, was hier eben als Dialog umstritten war ...ahn... sollten vielleicht auch darauf hinweisen, daß... (ULB21)

$\mathrm{COMP}+$ : wir - inclua falante e interlocutor na atividade: gerencie a dêixis pessoal; um noch mal... anzuknüpfen... umstritten war - dê (ou peça) razões

COMP-: bloß - minimize a imposição; ich meine, vielleicht -relativize a própria opinião; 
(PROP/T) ganz so eindeutig sehe ich das nicht. eins ist richtig. durch den Mauerbau hat die DDR natürlich vermeiden können [...] auf der anderen Seite mu $\beta$ man einem Märchen vorbeugen, daß [...] das ist durchaus nicht der Fall... (ULB22)

DIR: Märchen, durchaus nicht der Fall

$\mathrm{COMP}+$ : ganz so eindeutig... nicht - evite discordância: relativize a opinião do interlocutor; eins ist richtig... auf der anderen Seite... evite discordância: concorde simbolicamente

COMP-: ich sehe -relativize a própria opinião; man - impersonalize: gerencie a dêixis pessoal; muß einem Märchen vorbeugen... - indique relutância 